Liu Man Ying

\title{
Diretrizes para o Ensino Coletivo de Violino
}




\title{
Universidade de São Paulo
}

\author{
Liu Man Ying
}

\section{Diretrizes para o Ensino Coletivo de Violino}

Tese de Doutorado apresentada ao Programa de Pós-graduação do Departamento de Música da Escola de Comunicações e Artes da Universidade de São Paulo.

Área de Concentração: Processos de Criação Musical

Linha de pesquisa: Técnicas composicionais e questões interpretativas

Orientador: Prof. Dr. Gilmar Roberto Jardim

\section{São Paulo}


Autorizo a reprodução e divulgação total ou parcial deste trabalho, por qualquer meio, convencional ou eletrônico, para fins de estudo e pesquisa desde que citada a fonte.

Ying, Lui Man

Diretrizes para o ensino coletivo de violino / Liu Man Ying São Paulo : L. M. Ying, 2012.

208 p : il.

Dissertação (Doutorado) -- Escola de Comunicações e Artes / Universidade de São Paulo.

Orientador: Gilmar Roberto Jardim

1. Ensino coletivo de violino. 2. Instrumentos musicais. 3. Psicomotricidade. 3. Metodologia. I. Jardim, Gilmar Roberto. II Título. 
FOLHA DE APROVAÇÃO

Nome: Liu Man Ying

Título: Diretrizes para o Ensino Coletivo de Violino

Tese de Doutorado apresentada ao Programa de Pós-graduação do Departamento de Música da Escola de Comunicações e Artes da Universidade de São Paulo.

Aprovado em:

\section{Banca Examinadora}

Prof. Dr. Instituição

Julgamento Assinatura

Prof. Dr. Instituição

Julgamento Assinatura

Prof. Dr. Instituição

Julgamento Assinatura

Prof. Dr. Instituição

Julgamento Assinatura

Prof. Dr. Instituição

Julgamento Assinatura 


\section{DEDICATÓRIA}

À minha amada filha Vitória,

toda a minha inspiração,

que os coloridos da nossa terra

ladrilhem o seu caminho com a Música. 


\section{AGRADECIMENTOS}

Ao meu querido Nadilson, companheiro de todas as horas, por seu apoio e encorajamento imprescindíveis,

À minha mãe, meu maior exemplo,

À querida professora e amiga Maria Vischnia, por me ensinar tudo o que sei,

Ao meu orientador de mestrado, prof. Dr. Sérgio Cascapera, pela incansável e inestimável ajuda,

Ao meu orientador de doutorado, prof. Dr. Gil Jardim, por sempre me ajudar a desvendar novos horizontes,

À FAPESP, por todo suporte necessário à conclusão desta tese. 
Liu Man Ying. Diretrizes para o Ensino Coletivo de Violino. 2012. Tese (Doutorado) Escola de Comunicações e Artes, Universidade de São Paulo, São Paulo, 2012.

\section{RESUMO}

A presente tese desenvolve a aplicação de importantes fundamentos da psicomotricidade como base para o ensino coletivo de violino. Dessa forma, apresenta e discute tais elementos conectando-os ao processo do aprendizado musical infantil. Propõe também um modelo metodológico de ensino apoiado na percepção de acontecimentos musicais simultâneos.

Palavras-chave: ensino coletivo de violino, psicomotricidade, metodologia. 
Liu Man Ying. Guidelines for Violin Class Teaching. 2012. Tese (Doutorado) - Escola de Comunicações e Artes, Universidade de São Paulo, São Paulo, 2012.

\section{ABSTRACT}

This thesis develops the application of important fundamentals of psychomotricity for violin class teaching. It presents and discusses these elements connecting them to the infant musical learning process. It also develops a model methodology of education based on the perception of simultaneous musical events.

Keywords: violin class teaching, psychomotricity, methodology. 


\section{SUMÁRIO}

p.

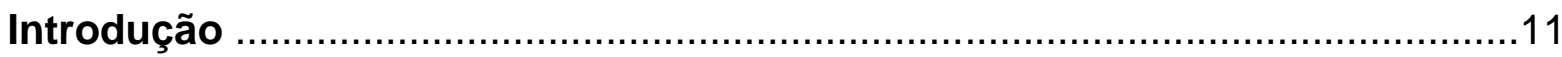

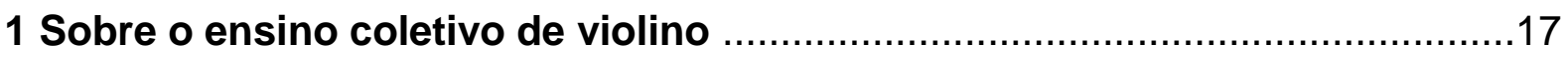

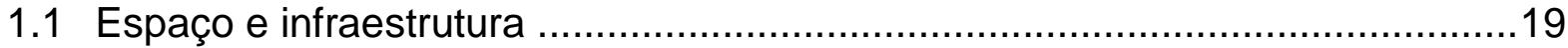

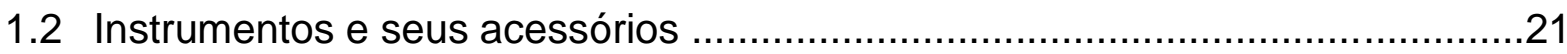

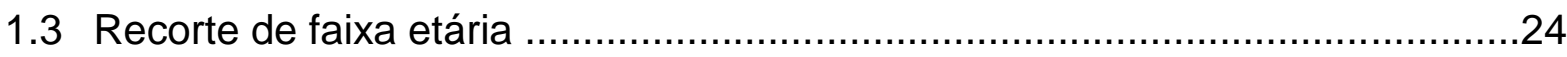

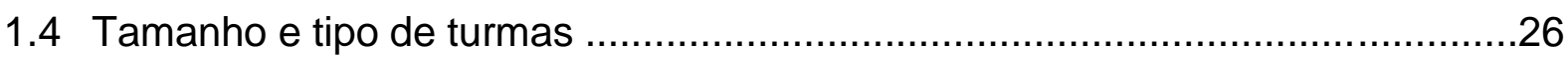

1.5 Frequência, duração e extensão do ensino coletivo de violino ........................31

1.6 Abordagens pedagógicas e metodológicas ..............................................34

2 Ensino coletivo de violino e psicomotricidade ........................................40

2.1 Fundamentos da psicomotricidade: o cérebro humano e suas funções.............43

2.2 Aspectos gerais do desenvolvimento psicomotor infantil...............................52

2.3 Fatores psicomotores aplicados ao ensino coletivo de violino...........................55

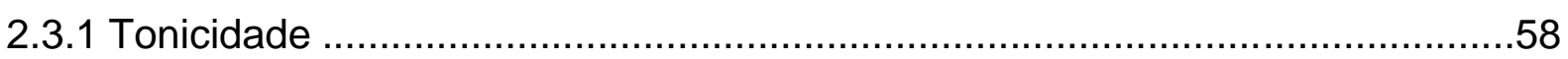

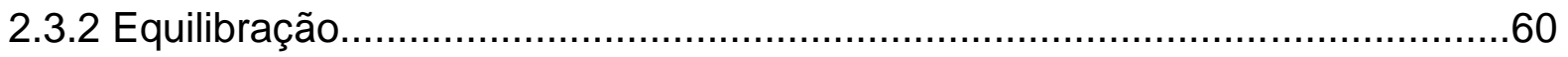

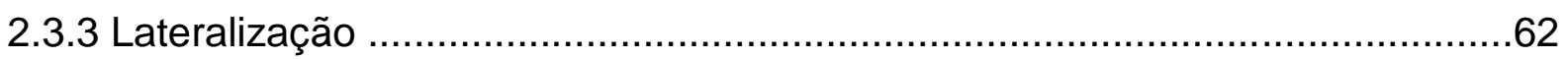

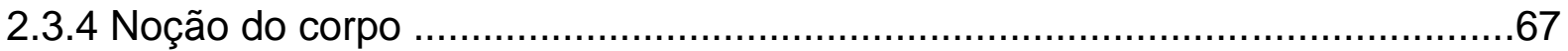

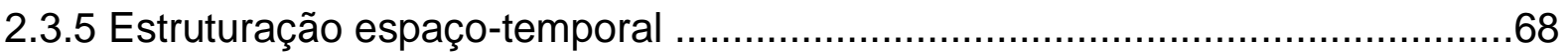

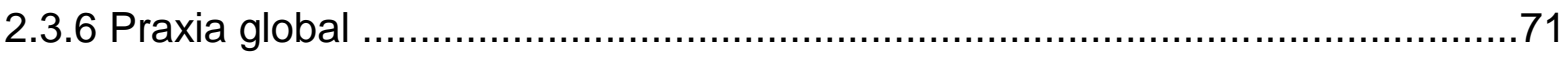

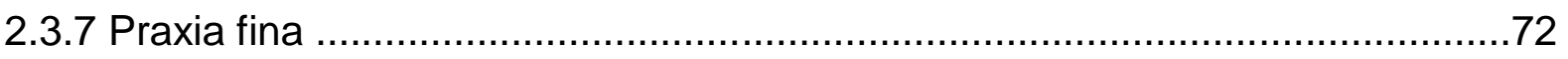

3 Exercícios preparatórios para o aprendizado no violino baseados em

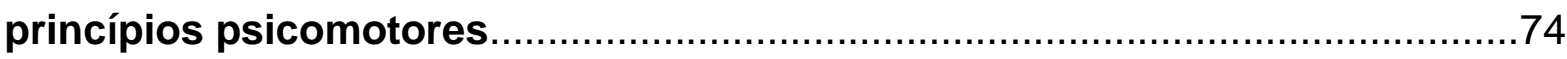

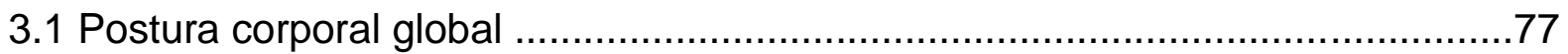

3.2 Exercícios preparatórios para mãos e braços ..............................................90

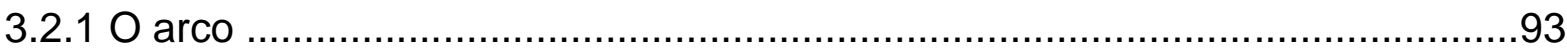

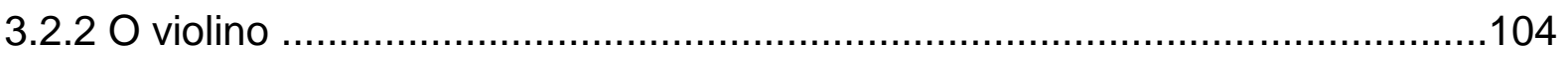


4 Diretrizes para o ensino coletivo de violino .113

4.1 Parâmetros curriculares para o ensino coletivo de violino 114

4.2 Escopo técnico para o ensino coletivo de violino .119

5 Método para o "Ensino Coletivo de Violino a partir da Psicomotricidade" 124

Considerações finais .202

Referências. 203 


\section{INTRODUÇÃO}

A presente tese tem por objetivo discutir questões relevantes do ensino coletivo de violino. Com foco em elementos da psicomotricidade na gênese do aprendizado infantil, propõe material didático com exemplos práticos, explorando contextos e desenhando metas a serem atingidas pelos alunos de violino.

Desde o início da década de 1990, o ensino coletivo de instrumentos de cordas se disseminou de maneira crescente como pedagogia musical em várias escolas de música públicas e em uma grande variedade de projetos sociais que empregam o ensino musical como veículo de ação social. Esses projetos são administrados por organizações sociais (OS), que recebem verbas do estado, ou por organizações não governamentais (ONG), sem fins lucrativos, por meio de leis de incentivo fiscal do governo federal. Além das entidades públicas citadas, entidades privadas também promovem esse modelo de ensino no estado de São Paulo.

Se por um lado essa forma de ensino se propagou de forma crescente, o mesmo não ocorreu com a formulação de metodologias que atendessem às necessidades específicas dos alunos brasileiros, oriundos, em sua maioria, de condições sociais mais humildes, muitas vezes de comunidades carentes.

O perfil do aluno brasileiro atendido pelas escolas de Música e projetos sociais que empregam o ensino coletivo não se assemelha ao perfil do aluno norte-americano, europeu ou asiático, haja vista as enormes diferenças culturais, de vivência musical e de condições sócio-econômicas. Para a grande maioria dos alunos brasileiros, a própria aquisição do instrumento é ainda uma dificuldade pela precariedade de sua situação financeira.

Para exemplificar o fato de como as diferenças culturais influenciam na concepção e na confecção de métodos de violino, observamos como Shinichi Suzuki elaborou seu famoso método de ensino de violino e demais instrumentos de cordas. Ele criou o método baseado nas características culturais de seu povo, e a disciplina e a priorização da educação eram as bases da cultura nipônica. Nesse ambiente, ele concebeu uma metodologia que incluía a participação das mães dos alunos como parte essencial do sucesso da aplicação do método. As mães deveriam aprender pelo menos todo primeiro volume do método para poder estudar junto com os filhos 
em casa todos os dias, além de corrigir suas eventuais falhas de postura e de leitura musical.

Tal situação de aprendizado idealizado por Suzuki parece extremamente improvável de acontecer na nossa realidade nacional, quando contraposta com a situação brasileira de evasão das crianças em idade escolar das escolas públicas por vários fatores, como abandono por parte de um dos pais ou de ambos, envolvimento com criminalidade e baixa qualidade no aprendizado. Os poucos alunos que conseguem ser atendidos por alguma escola de música pública ou um projeto social que ensina música, com a chegada da adolescência, muitas vezes eles se deparam também com a pressão da família para abandonar o estudo musical e procurar um emprego, em geral malremunerado, para ajudar no sustento da família.

Desse modo, constatamos que os pontos fundamentais a serem levados em consideração no processo de elaboração de metodologias e métodos de ensino são as questões culturais e o nível educacional do público a quem são destinadas. Para que a metodologia proposta seja eficaz na sua aplicação, deve ser compatível com a realidade social e a capacidade de compreensão do público a quem é direcionada.

Ao analisarmos a atual aplicação do ensino coletivo nos projetos sociais de ensino musical, constatamos grande variedade de formas de enfoque, de tamanho das turmas, de disposições sobre faixas etárias dos alunos, assim como de frequência, duração de aulas e, sobretudo, uma profusão de métodos e metodologias estrangeiras, em sua grande maioria em língua inglesa. Lamentavelmente, tanto as metodologias como seus materiais didáticos são utilizados de forma parcial pelos professores, sem o completo entendimento da proposta conceitual a que se propõem.

As melodias empregadas nos métodos de ensino coletivo estrangeiros são familiares ao público para quem foram escritas, mas para nossos alunos são geralmente desconhecidas. Com isso, perde-se o vínculo da identificação cultural, que facilitaria o aprendizado do instrumento nessa etapa preliminar.

A justificativa para o emprego exclusivo de melodias do folclore e de canções populares brasileiras, e a não utilização de melodias do repertório de outros países, tem como base o próprio processo de ensino do violino.

O uso do método coletivo para a iniciação ao violino ou a qualquer outro instrumento de cordas subentende uma iniciação ao instrumento limitada às noções preliminares de sua técnica básica. Passado esse período de aprendizado inicial, que 
dura em média de dois a três anos - a depender da idade média dos alunos, de sua capacidade de aprendizado musical e do controle da coordenação motora -, os alunos são encaminhados necessariamente para aulas no formato tradicional de ensino de violino - aulas individuais em que o aluno é atendido em suas necessidades específicas para 0 melhor aproveitamento do tempo e o aprimoramento técnico.

Aí, sim, nas aulas individuais, os métodos e as metodologias empregadas são, na sua maioria, muito semelhantes aos utilizados nos países de tradição de música ocidental erudita, ou seja, todo o repertório de concertos, estudos, métodos de técnica de violino são os mesmos empregados para se estudar o repertório consagrado da música ocidental erudita em qualquer parte do mundo.

Assim, o aluno não será desfalcado em sua formação se iniciar os estudos no instrumento por meio do folclore e do cancioneiro popular nacionais, pois, ao prosseguir seus estudos, o repertório consagrado de outros países será contemplado nas aulas individuais a seguir.

Uma importante questão a ser considerada quanto às metodologias de ensino coletivo existentes é a escassez de exercícios de preparação do aluno principiante para o aprendizado do instrumento. Não se conhece ainda no país uma metodologia de ensino coletivo de violino que se preocupe em desenvolver as questões de postura do aluno para que se evitem os vícios de aprendizagem que comprometem o desenvolvimento físico e motor do aluno, limitando o seu desenvolvimento.

De forma geral, o aluno com problemas de posicionamento do instrumento apresenta também problemas em outras atividades. Porém, se aqueles são corrigidos, ele também passa a se corrigir em outras áreas de deficiência postural, pois uma boa colocação do instrumento no ombro e nas mãos do aluno requer uma boa postura geral do corpo, já que este é uma unidade indivisível e seus movimentos são interligados; a ação de uma parte afeta todas as outras.

Esse panorama é absolutamente preocupante, uma vez que observamos propostas conceituais inadequadas sendo ministradas por professores mal preparados para atuar na formação musical das crianças brasileiras que pretendem aprender um instrumento.

O ensino coletivo de instrumento deveria ser fruto de uma política pública de educação nacional. É necessário e urgente atentarmos que o caráter assistencialista dos projetos sociais que utilizam a música como ferramenta não entende a 
importância de um ensino musical feito com excelência. Se assim fosse, teríamos um quadro bastante diverso deste que presenciamos em nosso país.

Um sintoma que demonstra a fragilidade dessa questão é o fato de não termos cursos de nível superior que abordem o tema nas universidades do estado de São Paulo. Não existem disciplinas nas grades curriculares que preparem o aluno para atuar na área de ensino coletivo, especialmente para os instrumentos de cordas. $O$ que percebemos é que os cursos de Música universitários formam instrumentistas, mas não os preparam para ser professores de instrumento.

Há ainda o fato de que o Brasil, que já não conta com longa tradição de ensino musical formal, baniu a Música das escolas públicas com a reforma do sistema de ensino, em 1974, comprometendo a educação musical e a formação cultural de todas as gerações subsequentes.

Como consequência, existe um descompasso na base da formação de profissionais nessa área. A premente necessidade de qualificação de professores de Música é assunto nevrálgico em nossos dias, especialmente se consideramos a lei 2732/08 aprovada pelo Senado, que torna obrigatório o ensino de Música no ensino fundamental ( $1^{\circ}$ e $2^{\circ}$ graus), alterando a Lei $n^{\circ}$ 9.394, de 20 de dezembro de 1996, Lei de Diretrizes e Bases da Educação.

Até agora ainda não enxergarmos diretrizes que possam trazer estímulo à organização do ensino da Música em nosso país. O ensino coletivo de instrumentos de cordas, por exemplo, deve ser entendido como um recorte absolutamente pertinente neste momento. Porém, o que observamos é a falta de clareza dos objetivos dessa ação por parte de muitas instituições, assim como dos projetos sociais, tornando o resultado desse processo pedagógico extremamente confuso e de difícil decodificação.

Diante de tal panorama, constatamos a necessidade de estabelecer bases e diretrizes para uma metodologia de ensino coletivo de violino fundamentada nos elementos da música brasileira: escrita em língua portuguesa, para facilitar a compreensão dos alunos quanto às propostas técnicas e metodológicas apresentadas; que apresente, passo a passo, os fundamentos da técnica do violino por meio dos princípios da psicomotricidade e do desenvolvimento motor; que tenha a preocupação de trabalhar questões posturais e de tonicidade para o melhor desempenho do aluno no instrumento. 
Nesta tese abordaremos especificamente o ensino coletivo do violino. No capítulo 1, discorreremos sobre definições do ensino coletivo como metodologia de violino para alunos iniciantes. Procederemos com a análise e considerações a respeito de questões que afetam as escolas e os projetos sociais. Traremos à luz fatores externos que limitam e dificultam a correta aplicação do ensino coletivo como metodologia e que muitas vezes dão origem a uma visão distorcida ou estereotipada de sua eficácia, colocando à prova sua validade comprovada.

Também arrolamos condições para um ensino coletivo efetivo, com critérios baseados em palestras e ditames de pedagogos de instrumentos de cordas norte-americanos reconhecidos nesse assunto, encontrados em ASTA Curriculum, Standards, Goals and Learning Sequences for Essential Skills and Knowledge in K-12 String Programs ${ }^{1}$, publicação da ASTA (American String Teachers Association), edição de 2011, cujos preceitos e metas foram ratificados na conferência anual da ASTA, ocorrida em março de 2011 em Kansas City, Missouri, EUA.

No capítulo 2 abordamos um ponto extremamente relevante desta tese, que diz respeito à proposição de práticas psicomotoras e de desenvolvimento motor aplicadas ao ensino coletivo e fundamentadas em bibliografia pertinente e em cursos de psicomotricidade oferecidos pelo Instituto de Psicomotricidade e Educação (ISPE-GAE) de São Paulo, a saber: "Psicomotricidade na Escola", "Práticas psicomotoras para Educadores" e "Psicomotricidade e Música".

A primeira e a segunda parte do capítulo 2 são dedicadas ao estudo dos fundamentos da psicomotricidade infantil e de seu desenvolvimento motor; a terceira é dedicada à aplicação dos fatores psicomotores ao ensino coletivo de violino, de forma a atingir condições consideradas ideais para o desenvolvimento do ensino coletivo dos instrumentos de cordas.

O capítulo 3 aborda a questão dos exercícios preparatórios apresentados como elementos de uma metodologia e como somatória de todos os aspectos anteriormente apresentados.

O capítulo 4 estabece diretrizes para o ensino coletivo de violino, isto é, parâmetros para uma nova metodologia, com padrões de referência para a sua aplicação. Pretende fornecer ao professor de violino um roteiro com a intenção de

\footnotetext{
${ }^{1}$ BENHAM, Stephen J.; WAGNER, Mary L.; ATEN, Jane Linn; EVANS, Judith P.; ODEGAARD, Denese; LIEBERMAN, Julie Lyonn. ASTA Curriculum, Standards, Goals and Learning Sequences for Essential Skills and Knowledge in K-12 String Programs. American String Teachers Association, 2011 edition, Fairfax, VA, USA.
} 
estimular seu trabalho por meio de elementos que propiciem o desenvolvimento de uma postura corporal saudável e equilibrada no ato de tocar, assim como a consciência pedagógica global para buscar o melhor universo musical para seus alunos.

E, por fim, o capítulo 5 aborda o desenvolvimento técnico e musical do aluno ao violino e apresenta conteúdos musicais especialmente criados com a finalidade de produzir a identificação cultural da criança brasileira com seu folclore. Acreditamos estar produzindo ferramentas facilitadoras do aprendizado musical, além de proporcionar parâmetros técnicos para o desenvolvimento dos cursos de violino coletivos. 


\section{SOBRE O ENSINO COLETIVO DE VIOLINO}

Em nosso trabalho anterior de pesquisa, a dissertação de mestrado intitulada "O ensino coletivo direcionado no violino", ECA-USP 2007, constatamos que o ensino coletivo de instrumentos de cordas surgiu como metodologia de ensino a partir da primeira metade do século XIX, nos Estados Unidos da América. No entanto, somente no início do século $\mathrm{XX}$ foi inserido na grade curricular das escolas públicas de ensino formal no mesmo país. No Brasil, o ensino coletivo foi introduzido por volta de 1970, principalmente por meio do trabalho do professor Alberto Jaffé, mas somente duas décadas depois ganhou relevância no cenário musical por ter sido adotado como principal metodologia dos instrumentos de cordas nos projetos sociais que empregavam o ensino musical.

Desde então, aprimoraram-se os métodos, porém a forma de ensino permaneceu essencialmente a mesma. Sua configuração é formada por um grupo de alunos, no mesmo estágio de desenvolvimento e com faixa etária próxima, que aprendem os fundamentos da técnica do instrumento e praticam os exercícios sempre em conjunto. Além dos diversos métodos aplicados, o que varia atualmente de lugar para lugar são os tamanhos dos grupos, assim como a frequência e a duração de cada aula.

Atualmente diversas escolas de música, públicas e particulares, assim como organizações sem fins lucrativos, como igrejas, clubes e outros tipos de agremiações e associações comunitárias, têm feito uso dessa eficiente metodologia de ensino. Nesse cenário, porém, nada se compara ao enorme crescimento da aplicação do ensino coletivo de violino em projetos de cunho social, que utilizam a música como veículo de seu programa. Por isso, concentraremos nossa atenção em destacar algumas situações do seu emprego nesses lugares. Não temos como meta fazer um levantamento ou uma análise apurada da realidade atual dos projetos sociais, mas sim traçar diretrizes para o perfeito desenvolvimento do ensino coletivo de violino em todos os ambientes possíveis.

Ao delinearmos os elementos-chave para o sucesso de uma boa prática do ensino coletivo de violino, é necessário considerarmos a variação dos objetivos, como públicos distintos, singularidades de atendimento, espaços e configurações únicos, assim como as diferentes formações dos professores de violino que atendem 
a esses projetos sociais. Uma reflexão em profundidade sobre o tema nos suscita algumas perguntas importantes, como, por exemplo: $O$ que é o ensino coletivo de violino? Em que consiste sua metodologia? Quais são as características de sua didática peculiar?

O ensino coletivo de violino é uma metodologia que atende principalmente e especialmente alunos iniciantes - essa é a sua missão primordial. Ele é a melhor e mais completa maneira de se iniciar o aluno na técnica básica do violino. O ensino coletivo não deve ser utilizado como uma metodologia que pretende atender a todos os requisitos da formação integral do aluno, ou seja, durante toda a sua vida discente. Uma prática saudável de ensino coletivo estabelece um tempo determinado para iniciar e outro para terminar seu programa, pois o aluno não deve permanecer nos grupos por tempo indeterminado.

O foco do ensino coletivo deve ser os primeiros anos do aprendizado do aluno, a postura corporal e instrumental e o ensino dos fundamentos da técnica do violino, de modo que, uma vez completado esses conteúdos iniciais, o aluno seja capaz de prosseguir seus estudos em aulas individuais, no formato tradicional de ensino, no qual o professor atende a um único aluno por vez, a fim de trabalhar com maior profundidade a técnica por meio de repertório e estudos mais avançados.

Algumas formas de organização das aulas são comumente confundidas com o ensino coletivo, entre elas: as masterclass, nas quais geralmente o professor atende a um aluno por vez, enquanto os outros assistem à aula ministrada; os workshops, que se apresentam no formato de uma palestra para um grupo de alunos, porém nem todos eles tocam; os ensaios de um naipe de violinos, em que um repertório orquestral é trabalhado, sem a preocupação de desenvolver ou aprofundar os aspectos da técnica instrumental.

Nenhuma dessas formas de organização de aulas configura o ensino coletivo, cuja metodologia supõe o trabalho de todos os alunos ao mesmo tempo, aprendendo o conteúdo técnico e superando as dificuldades comuns. O ensino da técnica instrumental e musical é a prioridade dessa forma de aula, que se assemelha ao ensaio de um naipe de violinos, porém com finalidades diferentes. Cada conteúdo é apresentado de maneira didática, e as dificuldades técnicas são inseridas progressivamente para facilitar o aprendizado do aluno iniciante.

Dessa forma, os alunos atuam como um grupo coletivo, pois todos ouvem a mesma explanação teórica sobre questões de equilíbrio corporal, de postura correta 
em relação ao instrumento, de teoria e conceitos musicais, além de realizarem exercícios de preparação muscular, de aprenderem a tocar o instrumento e tirarem dúvidas sempre juntos. Isso é diferente de classes que são compostas por vários alunos, com cada um deles tocando em um momento diferente e o atendimento do professor sendo dividido entre um grupo de aprendizes individuais, embora reunidos ao mesmo tempo e no mesmo espaço.

Eventualmente a atenção do professor se concentrará em determinado aluno por dificuldades ou dúvidas particulares, mas, em geral, ele manterá seu foco no aprendizado da classe como um todo e deve determinar o avanço do conteúdo musical e técnico pela velocidade de aprendizado da maioria.

A seguir abordaremos algumas questões de importância fundamental para o bom andamento das aulas de ensino coletivo.

\subsection{ESPAÇO E INFRAESTRUTURA}

Um ambiente propício ao estudo de um instrumento musical é dotado de qualidades acústicas favoráveis, com uma reverberação adequada para que o aluno consiga ouvir os harmônicos produzidos pelo seu instrumento. Por isso, as salas devem ser dotadas, de preferência, de um teto com pé-direito ${ }^{2}$ alto, ou seja, com altura adequada para acontecer essa reverberação. Segundo o Regulamento Geral de Edificações Urbanas ${ }^{3}$, a altura mínima do teto de um imóvel deve ser de 2,80 m. Porém, para uma boa acústica, estúdios de gravação adotam o pé-direito duplo, que seria o ideal para o nosso caso. Além disso, em um projeto de ensino coletivo, as salas destinadas a instrumentos de maior volume de produção sonora devem ser isoladas das salas destinadas a instrumentos com produção sonora menor.

\footnotetext{
2 Pé-direito é uma expressão utilizada em Arquitetura e Engenharia que indica a distância do pavimento ao teto.

${ }_{3}^{3}$ Capítulo III - Disposições interiores das edificações e espaços livres. Artigo 65. - A altura mínima ou pé-direito dos andares, em edificações correntes, destinados à habitação é de $2,80 \mathrm{~m}$. Esse valor poderá ser reduzido até ao limite de $2,60 \mathrm{~m}$ quando se trata de edificações isoladas ou em pequenos grupos, com o máximo de três pisos habitáveis. A altura mínima do rés-do-chão, quando destinado a estabelecimentos comerciais ou industriais, é de 3,00 metros. Disponível em: <<http://www.dominio-Ida.com/21-xptd38382.htm\#33 >>. Acesso em: 20 out. 2011.
} 
Por causa da questão acústica, os espaços utilizados para as aulas de ensino coletivo de violino devem ser ambientes fechados, munidos de paredes, portas, janelas e teto. Um espaço fechado também ajuda o professor a obter a concentração dos alunos, pois evita distrações desnecessárias. Boa iluminação, ventilação adequada, e a oferta de toaletes e bebedouros são essenciais à saúde dos alunos e certamente contribuem para um bom desenvolvimento nos estudos.

Além disso, o espaço deve ser de tamanho adequado ao número de alunos que o frequentam, de modo que eles possam se movimentar com folga, sem se esbarrarem ao tocar os instrumentos. É também necessário planejar o espaço necessário para a colocação de caixas de instrumentos, bolsas e pertences pessoais dos alunos. Uma sugestão de cálculo do espaço é reservar 1,5 $\mathrm{m}^{2}$ em média para cada aluno para o uso do espaço com conforto e segurança.

Muitos projetos sociais apresentam condições extremamente inadequadas em seus locais de atendimento, como os ambientes sem a infraestrutura mínima de paredes, teto e portas. Esses locais dificultam a concentração do aluno, além de trazerem problemas, como a incidência de sol e chuva sobre os instrumentos, destruindo o verniz e a madeira, isso sem mencionar o problema da falta de acústica. Outro extremo são as salas de aula sem janelas e sem ventilação de espécie alguma; alguns locais apresentam falta de iluminação adequada, configurando um ambiente poluído e insalubre para as crianças.

Outro problema são as salas de aula minúsculas, pequenas demais para a quantidade de alunos arrolada, para a produção de grande volume de sons e ruídos e com falta de espaço para a movimentação dos alunos e mesmo para a correta movimentação dos arcos sobre os instrumentos. Ambientes com tetos rebaixados também ocasionam problemas de excesso de reverberação sonora, e a falta de tratamento para isolamento acústico resulta em ambientes sonoramente desequilibrados, nos quais o som extravasa para outros ambientes, o que impede os alunos de se ouvirem tocando, tornando impossível trabalhar com acuidade a afinação, a sonoridade e os fraseados musicais.

O armazenamento inadequado dos instrumentos e materiais didáticos traz prejuízos, pois o seu acondicionamento em locais com umidade excessiva ocasiona a degradação precoce dos instrumentais, como o problema de mofo, trazendo riscos à saúde de quem os utiliza. Os instrumentos e materiais didáticos devem ser guardados em locais com boa circulação de ar para preservar o seu bom estado 
devem ser expostos à luz solar direta, nem ficar em ambientes com calor ou frio excessivos, sob o risco de sofrer avarias, como rachaduras no tampo de madeira. As partes integrantes do instrumento que são coladas ou ajustadas, ao passar por grandes variações de temperatura e pressão, também podem se soltar.

O preparo adequado do local destinado às aulas de ensino coletivo de violino contribui fundamentalmente para o sucesso de um processo de aprendizagem produtivo e tranquilo.

\subsection{INSTRUMENTOS E SEUS ACESSÓRIOS}

Os instrumentos musicais oferecidos aos alunos pelos projetos sociais de ensino musical, dadas raras exceções, costumam ser de péssima qualidade, com cordas e cravelhas que não mantêm a afinação do instrumento, além de produzirem uma sonoridade fraca e de baixa qualidade, tornando o desenvolvimento musical do aluno refém desse gradiente de qualidade. Os principais problemas nessa área são relacionados à qualidade e ao tamanho adequado dos instrumentos e seus acessórios.

Muitos instrumentos musicais oferecidos aos alunos não têm os ajustes necessários para o seu correto uso. É o caso dos cavaletes dos violinos com defeito na curvatura, que ocasionam uma postura incorreta do braço direito e dificultam o ato de tocar em uma corda só, sem esbarrar nas outras. Também as pestanas altas ou baixas demais, dificultam o correto dedilhar dos dedos da mão esquerda sobre o espelho do violino, acarretando dificuldades na afinação.

Uma situação comum em muitos projetos sociais é a falta dos acessórios necessários e de boa qualidade para o estudo do instrumento. Um exemplo notório é a falta de atenção que se dá à aquisição da espaleira, também conhecida como ombreira dos violinos. Uma espaleira de baixa qualidade ou mesmo a falta dela ocasionam defeitos na postura geral do aluno, além de causarem tensão excessiva nos ombros e problemas na coluna cervical que podem ser permanentes.

A espaleira é um acessório que é ajustado nas laterais e no fundo do violino e colocado por cima do ombro do aluno. O violino, por si só, na maioria das vezes não tem altura suficiente para se fixar sozinho no ombro esquerdo do aluno (tomando por 
medida a lateral do violino, desde a base do tampo até o topo da queixeira), não consegue preencher a contento o espaço que mede desde a base do queixo (mandíbula) até a base do pescoço (no osso da clavícula). Sem a espaleira, o violino fica solto no ombro. E o aluno, para não deixar cair o instrumento, necessariamente contrai a musculatura do ombro, fazendo-o subir na direção do queixo na tentativa de preencher o espaço vazio até o violino, gerando uma enorme e desnecessária tensão muscular. Por esse motivo, a espaleira é um acessório de importância vital para a saúde muscular e da coluna verterbral do aluno.

Uma justificativa comumente dada para dispensar o uso da espaleira é o fato de alguns violinistas famosos não usarem e consequentemente seus alunos também não. Entretanto, são poucas as pessoas que realmente possuem o perfil físico que as permitem dispensar o uso da espaleira e tocar violino sem apresentar tensão muscular nos ombros e sem prejudicar a coluna. Geralmente pessoas que possuem pescoço mais curto e tipo físico mais roliço são as que mais se encaixam nesse perfil, por ter a distância entre a clavícula e a mandíbula mais curta e, dessa forma, acomodarem melhor o violino nos ombros. Sobre essa questão, por se tratar de um grupo coletivo, os alunos apresentam diferentes tipos físicos e nem todos têm as condições físicas ideais para dispensar o uso da espaleira.

A adoção da espaleira contempla os diferentes tipos físicos de uma turma de violino coletivo, pois uma boa espaleira deve ser anatômica, ajustável tanto em altura como a permitir sua rotação de forma que acompanhe a angulação do ombro e da clavícula. Assim os alunos conseguem relaxar a musculatura dos ombros e não sobrecarregar a coluna. Nos casos de pessoas que possuem o tipo físico descrito anteriormente e de crianças pequenas em que o violino preenche a contento 0 espaço entre a clavícula e a mandíbula, recomenda-se, em vez da espaleira, o uso de pequenas borrachas ou esponjas, presas no fundo do violino por meio de elásticos ou faixas, para ajudar a manter o violino bem afixado nos ombros, sem escorregar.

Ainda sobre a importância de se ter um bom instrumental, existe a questão da falta de cordas de boa qualidade e de jogos de cordas extras para reposição. A qualidade das cordas afeta diretamente o rendimento das aulas, pois uma corda ruim desafina e se rompe com frequência, e o professor precisa interromper a aula para ajustar ou trocar a corda. Levando em consideração que uma turma coletiva tem em média 10 alunos, se cada uma das quatro cordas do violino desafinar apenas uma vez durante a aula, o professor terá que afinar 40 cordas, além do tempo que já gasta 
com a afinação de todos os instrumentos no início da aula. Isso atrasa demais a aula, quando não a impossibilita.

A falta de acessórios, como o breu, por exemplo, necessário para manter as crinas do arco em atrito com as cordas, impede a produção de som de boa qualidade, com toda a profundidade dos harmônicos naturais do violino. O uso de breu de baixa qualidade ocasiona a perda antecipada da validade da crina do arco, uma vez que produz resíduos em excesso e estes se fixam permanentemente na crina. Em pouco tempo, esses resíduos formam um aglomerado pegajoso que atrai a sujeira e ocasiona a perda da capacidade de produção de som pela crina.

E finalmente, para uma postura saudável do aluno ao violino, é de importância fundamental que este seja do tamanho adequado. Os violinos possuem variados tamanhos que servem às crianças menores, e esses tamanhos devem ser respeitados para que elas não tenham sobrecarga de peso nos ombros e nem forcem uma extensão do braço direito para alcançar o espelho onde irão dedilhar as cordas.

A medida adequada do violino para uma criança pode ser aferida por meio de um teste simples. Rolland (1974, p.61) afirma:

This can easily be tested by asking the child to reach around the scroll with the instrument in playing position. The second finger should reach completely around the scroll with the left arm slightly bent.

Em tradução livre, Paul Rolland diz que o teste para verificar se o tamanho do violino é adequado à criança consiste em pedir-lhe que segure a voluta do instrumento na posição de tocar, ou seja, com o violino no ombro. A criança deve conseguir circundar com o dedo médio da mão esquerda toda a voluta com o braço esquerdo levemente curvado, sem estar esticado.

Acontece, porém, de o professor de ensino coletivo encontrar sua turma pela primeira vez, sem ter em mãos todos os tamanhos de violinos disponíveis para realizar tal teste sugerido por Rolland. O professor pode precisar estabelecer primeiro os tamanhos de violinos para a sua turma antes de encomendar a compra desse instrumental. Para esses casos, é possível medir o tamanho do braço da criança para estipular o tamanho do instrumento que cabe a ela antes de providenciar sua aquisição.

Essa medida deve ser tomada com uma fita métrica ou trena. Deve-se medir desde a base do pescoço (onde termina o pescoço e começa o ombro) até a base do pulso (onde termina o pulso e começa a mão), com o braço esquerdo da criança 
esticado lateralmente e com a palma da mão voltada para cima. Para esse fim, realizamos um teste com crianças de várias idades e tamanhos de braços e construímos uma tabela de aferição (Tabela 1) com as medidas dos braços dos alunos e os violinos correspondentes:

Tabela 1 - Medidas de braço X tamanho de violino

\begin{tabular}{l|l}
\hline Tamanho de braço & Tamanho do violino \\
\hline Até $40 \mathrm{~cm}$ & $1 / 16$ (um dezesseis avos) \\
De $40 \mathrm{~cm}$ a $44 \mathrm{~cm}$ & $1 / 8$ (um oitavo) \\
De $44 \mathrm{~cm}$ a $48 \mathrm{~cm}$ & $1 / 4$ (um quarto) \\
De $48 \mathrm{~cm}$ a $52 \mathrm{~cm}$ & $1 / 2$ (um meio) \\
De $52 \mathrm{~cm}$ a $56 \mathrm{~cm}$ & $3 / 4$ (três quartos) \\
De $56 \mathrm{~cm}$ a $60 \mathrm{~cm}$ até mais & $4 / 4$ (inteiro) \\
\hline
\end{tabular}

A aquisição de instrumentos por um projeto social deve sempre levar em consideração uma provisão para compras futuras em curto espaço de tempo, pois, depois de um semestre de aulas, muito provavelmente uma grande parcela dos alunos necessitará de um instrumento de tamanho maior, de acordo com o seu crescimento. O mais importante, no entanto, é sempre deixar a criança usar o violino do tamanho adequado para ela em todos os momentos.

\subsection{RECORTE DE FAIXA ETÁRIA}

A turma ideal para o ensino coletivo de violino é a que reúne os alunos com idades semelhantes ou as mais próximas possíveis. Isso porque alunos de mesma idade ou idades muito próximas tendem a ter um ritmo de desenvolvimento motor e cognitivo semelhantes, garantindo uniformidade no aproveitamento das aulas. Essa configuração também facilita o entrosamento entre os alunos, pois eles apresentam interesses parecidos, típicos de sua faixa etária.

A mistura de alunos com grande diferença de idade em uma mesma classe proporciona uma desigualdade no desenvolvimento da turma, Fica impossível 
conciliar o ritmo de aprendizado e de desenvolvimento de crianças e de adolescentes, por exemplo.

Se for necessário juntar alunos de idades diferentes em uma mesma turma, a distância entre as idades dos alunos não deve superar dois anos, para não comprometer o bom andamento da aula.

Uma boa divisão nesse caso é juntar crianças de 6 a 8 anos; de 9 a 11 anos; e de 12 anos com os de idade superior. Lembrando que o ideal é que a turma tenha a mesma idade, ou senão, a mais próxima possível.

Todas as condições citadas acima têm como objetivo trabalhar com o ensino coletivo de uma maneira que favoreça o aprendizado dos alunos, na busca pelas melhores práticas pedagógicas do instrumento.

Embora essas questões se estendam a várias faixas etárias, nossa pesquisa atual se concentra nas etapas de desenvolvimento motor e neurológico de crianças dos 6 anos de idade até o início da adolescência, aos 12 anos. A escolha desse recorte etário se justifica por ser essa a faixa de idade em que a maioria das crianças inicia o aprendizado do violino.

Alunos dessa faixa etária convivem com limitações físicas e de apreensão de conhecimentos que eles próprios ainda não conseguem compreender plenamente. Muitas vezes, não conseguem distinguir suas dificuldades, nem tampouco comunicá-las ao professor. Pode acontecer também de o professor menos atento não perceber as dificuldades do seu aluno criança, assim como, mesmo as percebendo, não conseguir auxiliá-lo a contento.

Um dos objetivos principais da nossa pesquisa é obter por meio da investigação dos fatores psicomotores, do estudo dos conceitos gerais da psicomotricidade e das teorias de desenvolvimento motor, os fundamentos que nos auxiliem a trabalhar os problemas de coordenação motora e de apreensão do conhecimento de nossos alunos, crianças de 6 a 12 anos.

Outro objetivo igualmente importante é ajudar o professor a compreender a diferença entre disfunções de comportamento e de aprendizagem que têm origem neurológica, isto é, desordens ou desvios de comportamento que encerram um problema de aprendizagem, como, por exemplo, a dislexia; daqueles problemas que são de natureza incapacitante, como, por exemplo, o retardo mental.

Por meio desses estudos, podemos definir o campo de ação do professor de ensino coletivo e dessa forma estabelecer o que é possível ser trabalhado em classe 
com os alunos ou quando é necessário um encaminhamento para um atendimento especializado em psicomotricidade.

A necessidade de mantermos um olhar sobre a observação psicomotora, segundo Vítor da Fonseca ${ }^{4}$, justifica-se por que:

...existe uma grande abundância de trabalhos de investigação que
relacionam a integridade psicomotora com a aprendizagem eficiente;
reconhece-se a existência de dificuldade de aprendizagem e de
perturbações de comportamento em crianças que não podem ser
categorizadas como deficientes; a prevenção, a compensação, a
reeducação e a terapia de disfunções psicomotoras podem impedir
que um problema ligeiro se transforme num problema mais sério
(FONSECA, 1995, p.4-5).

Tudo isso deve ser feito respeitando as peculiaridades e especificidades de cada aluno. Para tanto, devemos buscar o conhecimento das causas de cada dificuldade apresentada para saber se esta se refere a problemas de ordem psicomotora: tonicidade muscular, equilibração, dominância lateral, estruturação espaço-temporal, problemas com praxias global ou fina ou dificuldades neurológicas. Só depois disso, podemos traçar um plano de ensino que contemple todas essas questões.

\subsection{TAMANHO E TIPO DE TURMAS}

A qualidade do ensino e do aprendizado é diretamente proporcional ao número de alunos atendidos em uma turma de ensino coletivo.

Podemos considerar razoável um grupo de 10 alunos de violino para que um único professor consiga passar o conteúdo e ainda atender às demandas individuais que se apresentam durante as aulas. O acréscimo de um ou dois alunos pode ainda ser admitido sem grandes perdas, porém, quando o número de alunos supera em muito esse número, o aprendizado e a qualidade das aulas decaem significativamente.

\footnotetext{
4 Vitor da Fonseca é mestre em Ciências da Educação e doutor em Educação Especial e Reabilitação, renomado autor de livros, conferencista e professor.
} 
Isso ocorre porque, em uma dinâmica de aula coletiva de violino, o professor necessita ministrar o conteúdo na frente de toda a classe, seja demonstrando algum elemento técnico no instrumento, seja mantendo a pulsação rítmica de algum exercício para todos tocarem juntos. Ao mesmo tempo ele deve ser capaz de dar atenção individualizada a cada um dos alunos, para verificar se estão acompanhando os exercícios, para corrigir eventuais erros e sanar dúvidas. Os alunos, por sua vez, necessitam trabalhar tanto sua compreensão intelectual de determinado conteúdo técnico, quanto o domínio dos movimentos sobre o instrumento, que é obtido por meio de exercícios de repetição, nos quais os alunos aprendem progressivamente a controlar seus músculos para efetuar os movimentos requeridos.

Problemas ocorrem quando, mesmo tendo compreendido o conceito e o modo como se deve exercer determinado movimento, o aluno não consegue, na prática, efetuar esse movimento por não ter ainda suficiente controle motor de seus membros. Nesse momento, é crucial a ajuda do professor, que, por meio da assistência individual, auxilia o aluno a compreender a gênese do movimento correto a ser efetuado e como fazer para controlá-lo. Por assistência individual entendemos o trabalho do professor ao se utilizar de toques e contenções com as mãos sobre partes do ombro, cotovelo, costas, mãos e dedos do aluno com o intuito de ajudá-lo a realizar determinado movimento.

Como exemplo, podemos citar a situação em que o aluno está aprendendo a tocar com o arco sobre uma corda do violino e precisa conseguir manter o caminho do arco paralelo ao cavalete do instrumento a fim de produzir uma boa sonoridade, uniforme e constante. Nesse instante, o aluno pode ter dificuldade para entender como seu braço direito deve se posicionar a cada momento da movimentação do arco, que corre desde o talão até a ponta sobre a corda. Então, por meio da assistência do professor, que segura em seu braço ou em sua mão direita, realizando o movimento junto com ele, o aluno tem a compreensão facilitada. Dessa forma, o aprendizado progride.

Quando há um número excessivamente grande de alunos na sala de um único professor, o atendimento individual se perde, pois o professor não consegue segurar o braço ou a mão de cada um dos alunos para auxiliá-los, deixando muitos deles sem atendimento. Essa assistência individual é parte essencial no aprendizado do violino, principalmente no início do processo de aprendizagem. Quanto menor a idade das 
crianças envolvidas, mais fundamental será esse atendimento, por causa da fase de maturação de seu sistema de controle motor e neurológico.

Há essencialmente duas formas de se praticar o ensino coletivo: em turmas heterogêneas (composta por vários ou todos os tipos de instrumentos de cordas) e turmas homogêneas (composta por um só tipo de instrumento de cordas). Analisaremos a seguir os pontos positivos e negativos de cada uma dessas organizações de turmas.

Para a maioria dos projetos sociais, infelizmente a disponibilidade de espaço é o fator principal, determinante na decisão pela implantação de um trabalho de ensino coletivo heterogêneo, pois em muitos lugares existe somente um único espaço disponível.

O grupo heterogêneo é então preferido não por causa de um ponto de vista pedagógico, mas por ser mais chamativo e atraente como mostra de resultado de trabalho dos projetos sociais. Outra questão que pesa nessa decisão é o ideal de se construir a curto ou médio prazo um trabalho com grupo de cordas para se formar uma orquestra.

Nessa linha de trabalho, o ideal é que haja, no mínimo, quatro professores para atender a uma turma heterogênea, sendo um professor de cada instrumento. Um dos professores ficaria encarregado de ministrar a aula, enquanto os outros três atenderiam aos alunos, auxiliando-os na leitura musical, na correção da postura, entre outras questões técnicas e musicais.

Respeitando a questão do cálculo de espaço por aluno, podemos afirmar que, de maneira geral, uma turma de ensino coletivo heterogêneo consegue ter um aproveitamento razoável com até 30 alunos, considerando que, em média, serão 2/5 de violinos, $1 / 5$ de violas, $1 / 5$ de violoncelos e 1/5 de contrabaixos, o que significa ter 12 violinos, 6 violas, 6 violoncelos e 6 contrabaixos. É comum encontrarmos um número menor de alunos estudando contrabaixo por conta da pouca procura pelo instrumento e também por ser o instrumento de maior custo; as escolas e os projetos sociais optam por comprar menos contrabaixos e aumentar o número de outros instrumentos de cordas. Então, na prática, a título de exemplo, num conjunto com 30 alunos não raro podemos encontrar 14 violinos (divididos entre primeiros e segundos violinos), 8 violas, 6 violoncelos e 2 contrabaixos.

Analisaremos a seguir a forma de divisão de turmas que tem melhor aproveitamento e rendimento em classes: se uma turma grande e heterogênea, com 
30 alunos e quatro professores, ou os mesmos 30 alunos divididos em quatro salas homogêneas, cada qual com seu professor.

Muitos projetos sociais defendem o ponto de vista de que tocarem todos num grande grupo denota mais integração entre os alunos, o que representa melhor a prática da ação social. Alegam que, dessa forma, os alunos vão apreciar mais a atividade musical, e a imagem do projeto será melhor nas atividades de divulgação. Por isso, preferem os trabalhos com grandes grupos heterogêneos, com turmas numerosas que ultrapassam em muito o número de 30 alunos, justificando essa escolha no fato de que se o número de professores e alunos permanece igual em ambos os casos, então os resultados dos dois tipos de ensino coletivo também seriam os mesmos.

Porém, pela nossa experiência, quando um conjunto de ensino coletivo heterogêneo ultrapassa a média de 30 alunos por turma, há uma perda significativa no aproveitamento dos alunos, pois, mesmo com quatro professores dando aulas, a possibilidade de atender melhor cada aluno diminui por causa do número elevado de pessoas.

Outro fator que acarreta prejuízo ao aprendizado é o nível de ruídos sonoros advindos da prática dos exercícios conjuntos, fator que é agravado nos trabalhos com grupos heterogêneos, pois o aluno passa a não escutar direito o que ele próprio está tocando por causa do grande volume de som produzido, que dispersa a atenção, dificulta uma audição mais acurada sobre todos os elementos musicais trabalhados e prejudica uma série de quesitos, como a afinação, a produção de uma boa sonoridade, fraseados musicais, pulsação rítmica e a percepção do resultado sonoro de cada um e do grupo como um todo.

Outro aspecto que depõe contra as turmas heterogêneas é o cansaço causado pela espera demorada por alguns grupos de alunos. Enquanto, por exemplo, os violinos estão fazendo exercícios que tratam de problemas específicos da técnica do instrumento ou da partitura, os demais alunos de outros instrumentos ficam parados, esperando a sua vez de tocar, o que retarda o processo de aprendizagem e também tira a concentração dos que esperam.

Em um grupo homogêneo esses problemas são minimizados, pois o volume sonoro produzido é menor e, consequentemente, o aluno escuta o que toca e o que o colega está tocando. Além disso, todas as questões musicais e técnicas podem ser mais bem trabalhadas; já que o professor aumenta sua capacidade de assistência 
individual por ter menos pessoas para atender em um mesmo período de tempo; e o problema de esperar outro grupo aprender uma passagem específica é superado, pois todos tocam as mesmas partes e podem praticar juntos.

Por essa razão, a matemática não é exata nessa equação, pois, com o mesmo número de alunos e de professores, quatro turmas homogêneas menores aproveitam melhor a aula que uma turma grande heterogênea. A atenção e a concentração dos alunos melhoram quando eles trabalham em grupos menores.

Por isso, quando existe disponibilidade de espaço, é preferível dividir uma turma grande heterogênea em várias turmas menores homogêneas, pois se mantém o mesmo número de professores dando aula, porém em ambientes separados, com cada professor cuidando de uma turma, resolvendo-se dessa forma o problema do excesso de volume sonoro durante as aulas e de melhor aproveitamento do tempo. Mesmo quando existe apenas um único espaço disponível, é possível planejar o uso do espaço para aulas de várias turmas homogêneas em dias e horários diferentes.

Para se obter um trabalho produtivo com uma turma de ensino coletivo homogêneo, o número de alunos varia de acordo com o tipo do instrumento de cordas, principalmente devido ao tamanho de cada instrumento. Por isso, turmas de violino e de viola costumam ser mais numerosas do que turmas de violoncelo e de contrabaixo pelo fato de os instrumentos serem menores e, portanto, ocuparem menos espaço.

O fato de violoncelos e contrabaixos ocuparem mais espaço na sala reduz também a capacidade de o professor atender a um número elevado de alunos por vez, pois se deve levar em conta a disposição dos instrumentos ao redor do professor e a sua capacidade de visualizar todos os alunos e alcançá-los para dar-lhes assistência individualizada. De maneira geral, para o bom aproveitamento e desenvolvimento dos alunos, uma turma de ensino coletivo homogêneo de violinos é composta por até 10 alunos, o mesmo número para violas; violoncelos e contrabaixos, em menor número, de até 6 alunos.

No trabalho com as turmas homogêneas, é necessário desenvolver momentos de ensaio com os outros grupos instrumentais, pois assim todos poderão ensaiar um repertório conjunto, em uma prática orquestral. Esses momentos são muito importantes para o desenvolvimento da escuta harmônica e da prática musical como um todo. 
Dessa forma, fazemos a distinção entre o conteúdo a ser ensinado na sala de aula e no momento do ensaio: na sala de aula são ensinados os elementos técnicos e musicais novos e estudados com maior acuidade; no ensaio com o grupo maior heterogêneo, serão apenas repassadas as músicas do repertório sem despender muito tempo com a técnica instrumental.

Desse modo, por todas as razões citadas acima, acreditamos que o trabalho com turmas menores homogêneas seja a melhor forma de ser realizar o ensino coletivo de violino.

\subsection{FREQUÊNCIA, DURAÇÃO E EXTENSÃO DO ENSINO COLETIVO DE VIOLINO}

$\mathrm{Na}$ fase inicial do aprendizado do violino, quanto maior a frequência das aulas, melhor será o rendimento e o aproveitamento dos alunos. Isso ocorre principalmente porque no início do aprendizado o aluno necessita de correções constantes na postura corporal; caso contrário, ele pode facilmente se acostumar com uma posição errada no instrumento, adquirindo vícios na maneira como toca o instrumento.

Em sistemas de ensino coletivo consagrados internacionalmente, como no caso do "El Sistema", ou o Sistema de Orquestras Juvenis e Infantis da Venezuela, (FESNOJIV) criada em 1979 por Jose Antonio Abreu ${ }^{5}$, os alunos têm aulas de Música e de instrumento cinco dias por semana, durante todo o período em que não estão nas escolas de ensino formal. São cerca de cinco horas diárias, divididas entre aulas, ensaios, treinos supervisionados e atividades musicais lúdicas.

Esse contato diário e intenso com os instrumentos e com os professores torna o aprendizado especialmente eficaz. Os alunos praticamente não estudam violino em suas casas no início do aprendizado, mas o fazem junto com os professores em cinco dias da semana.

No caso da nossa realidade brasileira, o ideal é que o aluno consiga ter contato diário com o instrumento para poder estudar. Igualmente importante é que tenha o maior número de aulas possível com o professor para ter postura e questões musicais corrigidas. Para isso, é necessário que o aluno possua seu próprio

\footnotetext{
${ }^{5}$ Disponível em: <<http://www.fesnojiv.gob.ve/es/metodologia-de-el-sistema.html〉>. Acesso em: 08 novembro 2011.
} 
instrumento ou que possa levar para casa um instrumento emprestado. Outra opção é conseguir estudar todos os dias no espaço do projeto social.

Em todos os casos, a frequência mínima para um trabalho de ensino coletivo funcionar adequadamente é de pelo menos duas vezes por semana, com duração de uma hora e 30 minutos por aula. Essa duração da aula é o tempo mínimo necessário para que o professor possa dar aula, ter tempo de afinar os instrumentos antes e durante as aulas, além de fazer pequenos ajustes neles, quando necessário, principalmente por causa da baixa qualidade dos instrumentos que são oferecidos e também por conta do seu uso frequente pelas crianças. A diminuição da frequência e da duração das aulas acarreta, inevitavelmente, restrições no desenvolvimento do grupo.

Conforme já tratado anteriormente, o processo de aprendizagem do violino pelo aluno iniciante nas aulas coletivas é progressivo. A iniciação ao instrumento é feita durante dois ou três anos, no máximo, quando se estudam os fundamentos da técnica do violino.

Passado esse tempo, o aluno deverá ter domínio suficiente da técnica do violino para prosseguir seus estudos por meio de aulas individuais, no formato tradicional, com uma supervisão mais detalhada dos vários aspectos de seu aprendizado. Essa passagem para as aulas individuais deverá ocorrer de forma natural, como consequência do bom aproveitamento do aluno nas aulas coletivas.

Entretanto, o tempo do aluno em grupos de ensino coletivo pode variar devido à idade em que ele se iniciou no instrumento; contudo, não se recomenda ultrapassar o tempo máximo de três anos.

Alunos de pouca idade necessitam de mais tempo para amadurecer o domínio da técnica do que alunos com mais idade por causa do processo do amadurecimento do controle psicomotor. Consequentemente, eles demoram mais a ficar preparados para a passagem às aulas individuais. Não obstante, o tempo sobressalente que necessitam para essa fase não é diretamente proporcional à diferença de idade entre eles. Tomemos como exemplo uma turma com alunos de 10 anos. Ela necessita em média de dois anos de aulas no sistema do ensino coletivo de violino antes de estar apta a aulas individuais. Um aluno de 6 anos de idade deveria, pela lógica, gastar esses mesmos dois anos, acrescidos da diferença de 4 anos que os separam (10 - 6 $=4$ anos). 
Porém, com um bom trabalho de preparação dos alunos para o ensino coletivo de violino, essa diferença de tempo no rendimento das turmas mais jovens diminui consideravelmente, ou seja, um aluno de 6 anos de idade chegará ao mesmo patamar de domínio da técnica básica de violino que um aluno de 10 anos, acrescentando mais um ou no máximo dois anos de estudo do que o aluno mais velho.

Então, em termos gerais, se um aluno de 10 anos precisa de dois anos de estudo no ensino coletivo, o aluno de 6 anos bem preparado gastará apenas três anos para estar pronto para as aulas individuais, com a grande vantagem de estar estudando o instrumento em uma idade bem tenra, quando as conexões neuronais ainda estão em processo de formação e não totalmente consolidadas, o que favorece o aprendizado do violino, pois o ato de tocar passa a ser incorporado aos movimentos naturais e orgânicos do corpo da criança.

Uma situação irregular que encontramos em muitos projetos sociais que não priorizam a parte pedagógica musical é o prolongamento indefinido da permanência dos alunos nos grupos de ensino coletivo, sem que se ofereça conteúdo condizente com o longo tempo do curso. Não há justificativa razoável para manter o aluno num grupo de ensino coletivo por mais que três anos de curso, no máximo.

Um cenário questionável que encontramos são alunos que estão há mais de oito anos num grupo coletivo, fazendo sempre o mesmo repertório e estudando o mesmo conteúdo que seria adequado apenas para os dois primeiros anos de curso.

Isso ocorre quando não há um planejamento eficiente do conteúdo programático desses cursos ou quando, por falta de uma visão adequada da parte pedagógica, não se oferecem condições adequadas para o aluno prosseguir em seus estudos em aulas individuais.

Constatamos, dessa forma, a importância de um bom planejamento e do prosseguimento de curso para o melhor aproveitamento dos alunos no aprendizado do violino. 


\subsection{ABORDAGENS PEDAGÓGICAS E METODOLÓGICAS}

Os princípios norteadores da educação musical infantil se aplicam ao ensino coletivo, que nada mais é do a prática da pedagogia musical no instrumento. Portanto, o que podemos afirmar dessa profunda relação entre a educação musical infantil e o ensino coletivo de cordas é que quanto mais cedo estimularmos as crianças para a música, maior será sua capacidade de aprendizagem futura.

A aprendizagem é o objetivo central de todo o processo da educação. Seja no ensino do violino ou de qualquer outra meta educacional, sempre estará ocorrendo uma interação entre o estudante e o professor. A forma como esta interação acontece depende em grande parte de como o professor estruturou o local e o ambiente de aprendizagem. Vemos, portanto, a responsabilidade fundamental do professor de entender como uma pessoa aprende e que condições afetam sua aprendizagem, se todas as habilidades ensinadas são aprendidas da mesma maneira ou se são afetadas por variáveis ou tipos de situações.

Ao professor, cabe a tarefa de entender quais aspectos do comportamento humano envolvem o processo da aprendizagem, para se obter um ponto de partida para a análise de como ocorre este processo. Uma vez compreendido este ponto, o próximo passo é determinar se a maneira como a aprendizagem ocorre é semelhante ou diferenciada para cada tipo de comportamento.

Neste ponto, é importante que se faça a distinção entre orientação musical e educação musical. A orientação musical é definida como informal e a educação musical, ou a maior parte dela, como formal. Por sua vez, a orientação musical informal pode ser estruturada, ou não; a diferença está na ação dos pais ou professores, que podem ou não planejar e direcionar essa orientação. O renomado professor de educação musical Edwin Gordon ressalta que:

... uma característica marcante, quer da orientação estruturada quer da não-estruturada, é que nenhuma delas impõe informações ou competências à criança. Pelo contrário, as crianças são postas em contato com a sua cultura e encorajadas a absorvê-la. (GORDON, 2008, p.7)

A criança, portanto, é encorajada a responder naturalmente a estes estímulos de orientação que recebem dos pais. 
Na educação formal, diferentemente, há um planejamento específico daquilo que será ensinado à criança. A informação é oferecida organizada e dentro de um parâmetro de tempo, e o que se espera da criança é uma cooperação ativa e respostas específicas. Gordon afirma que:

Os pais que consigam cantar com afinação razoável e movimentar o corpo de forma flexível com movimentos livres e fluidos, e que disso tirem prazer, tem as condições básicas para orientar e instruir musicalmente os filhos, mesmo que não toquem um instrumento musical. (GORDON, 2008, p.8)

O lar da criança é o primeiro lugar onde ocorre a estimulação musical, uma vez que os pais são os primeiros e mais marcantes professores que a criança terá contato. Eles não precisam ser músicos amadores ou profissionais para instruir os filhos no desenvolvimento da compreensão musical, da mesma forma que não necessitam ser grandes oradores e escritores para ensinar os filhos a falar e a escrever na língua materna.

Essa estimulação no âmbito familiar é a raiz do desenvolvimento da aptidão musical das crianças, e consiste em uma orientação dos pais de forma lúdica e natural, que exponha a criança aos elementos musicais da sua cultura. E nada melhor para esse momento do que as cantigas do folclore nacional, entoadas com ou sem os jogos e danças que acompanham cada canção. Esse aprendizado deve ser feito de forma espontânea sem cobrança de resultados, considerando que crianças em idade pré-escolar não devem ter o desenvolvimento de suas capacidades musicais avaliadas com base na capacidade de um adulto.

Edwin Gordon (2008) postula que para as crianças aprenderem a executar musicalmente usando o canto e a entoação, é necessário que recebam orientação informal e educação formal de qualidade e em grande quantidade. As crianças pequenas reagem naturalmente ao ritmo com movimentos fluidos e flexíveis, se elas não forem estimuladas a se movimentar continuamente dessa forma, não aprenderão a entoar padrões rítmicos com flexibilidade e fraseado. Gordon afirma que:

A informação é recebida e retida no cérebro como resultado do movimento que é sentido em primeiro lugar através dos braços e pernas. Sem a transmissão através do corpo inteiro, o cérebro permanece, para todos os efeitos, adormecido. Ou seja, o corpo deve sentir antes que o cérebro possa compreender. É axiomático que o ritmo não possa ser ensinado cognitivamente e diretamente através do cérebro, como é tradicionalmente e futilmente tentado por muitos teóricos musicais. (GORDON, 2008, p.14) 
Para a adoção de uma boa proposta pedagógica do ensino coletivo de cordas, é necessário que sejam estabelecidas metas educacionais tendo sempre em vista o aprendizado do aluno, por meio de metodologias consistentes e didáticas que se dedicam tanto à parte técnica como à musical e que sejam de fácil compreensão tanto para o professor como para o aluno.

A falta de visão pedagógica do projeto musical e a inexistência de metas e objetivos a serem alcançados pelo ensino coletivo geram muitas confusões nos projetos sociais. Muitos deles não conseguem estabelecer claramente o alcance da dita parte "social" do projeto e não entendem que ensinar música com profundidade e eficiência de resultados é parte do "fazer social" da entidade. Esse entendimento limitado do papel da parte "social" dos projetos muitas vezes torna o ensino musical desleixado, sem compromisso com o real aprendizado do aluno. Facilmente o ensino musical é confundido com entretenimento, já que não é incomum o pensamento limitado de que qualquer coisa que se ofereça à criança com risco social é válida, desde que ela seja tirada da marginalidade das ruas.

Entretanto, se o ensino coletivo musical não for benfeito, o aluno ainda estará à margem do aprendizado real, ou seja, não estará incluído na iniciação à música e ao instrumento, não importa quanto tempo passe no projeto ou na escola de música.

Por outro lado, ao analisarmos essas questões pedagógicas do ensino de um instrumento musical, não é raro encontrar um mesmo quadro de problemas nas salas de aulas tanto dos conservatórios quanto das escolas de música, sejam em aulas de instrumento em estúdios privados, faculdades de ensino superior ou projetos sociais.

No processo de aprendizado do instrumento, os alunos apresentam facilidades e dificuldades de coordenação físico-motora, apreensão de conceitos, elaboração e síntese de pensamentos. O que varia são os níveis de facilidade e dificuldade, assim como o grau de elaboração e o nível de controle motor exigido nos diversos ambientes de ensino.

Da mesma maneira, observamos a limitação e a falta de compreensão do professor de instrumento para lidar com as dificuldades apresentadas pelos alunos, as quais podem ser tanto de coordenação motora e de tonicidade muscular, como de apreensão do conhecimento musical e da técnica do instrumento.

Com frequência observamos que o professor parte em busca de soluções para esses problemas, baseado somente na sua própria experiência e no seu histórico de aprendizagem. O resultado é uma forma inconsistente de procura por 
tentativa e erro, o que limita suas possibilidades de ajudar efetivamente o aluno. Para piorar o quadro, geralmente evitando parecer incapaz diante dos alunos, o professor de instrumento toma como universais as suas verdades particulares. Isso é feito sem se levar em conta as enormes diferenças de constituição física entre eles: desde variações de tamanho de mãos e braços, de comprimentos de pescoços, até angulações diferentes da queda dos ombros, formatos diversos de mandíbula e maxilares. É necessário também levar em consideração as diferenças no ritmo do desenvolvimento da coordenação motora e intelectual de cada indivíduo, sem falar das diferentes fases do desenvolvimento físico e mental nas várias faixas de idade.

Portanto, para estabelecer um trabalho pedagógico eficiente e favorável ao ensino coletivo de violino, a primeira premissa é a criação de um ambiente favorável à aprendizagem, isto é, que seja acolhedor e estimulante, que considere a singularidade de cada criança que é portadora de uma bagagem cultural, com uma expressividade próprias. Por isso, é necessário dar-lhe espaço para sua inserção no grupo.

O professor deverá ter a flexibilidade necessária para ajustar-se a cada um de seus alunos, para levar adiante a tarefa de seus desenvolvimentos pessoais. Deve permitir que as vivências afetivas de cada criança tenham significado, acompanhando-as em sua maturação na evolução de seu controle motor e de seus movimentos até o aflorar de sua expressividade individual e de suas capacidades.

Esse clima de acolhida e de segurança emocional favorece a aquisição do conhecimento e das aprendizagens, além de possibilitar à criança a descoberta sobre si própria, a partir de suas sensações, percepções e experiências. Somente desse modo, o aprendizado terá significância real para a criança, pois essa tomada de consciência permite a interiorização do conhecimento por meio da reflexão e autoconsciência.

Ao ajudarmos uma criança a se tornar um ser de comunicação, de expressão e de criação por meio do estudo da música e do violino, estaremos favorecendo o seu comportamento social, seu sentimento de pertinência ao grupo. Isso porque não se cria somente para si, mas sempre para os demais, o que propicia a sua abertura para encontrar-se com o outro através do relacionamento, permitindo um desenvolvimento saudável tanto corporal como afetivo.

O desafio do professor de ensino coletivo é ensinar um só conteúdo com abordagens diferentes de acordo com as diversas capacidades de compreensão e 
desenvolvimento do grupo na aquisição de competências. Para tanto é indispensável que o professor também seja capaz de escutar a emoção da criança, suas dificuldades e sentimentos de bem-estar.

Além disso, o professor nunca deve subestimar a capacidade de compreensão e a inteligência de seus alunos, de modo que os novos conceitos e elementos técnicos devem vir sempre junto com a explicação acerca do motivo e da consequência, para que a criança possa refletir sobre a razão de fazer determinado movimento com o instrumento e também sobre os resultados que esse movimento produz. Dessa forma, além de trabalhar a parte motora estará exercitando a capacidade de raciocínio dos alunos, sempre com a meta de conduzí-los para a autosuficiência, pois na medida em que eles aprendem a pensar por si mesmos, definem melhor os seus problemas e aprimoram sua busca por soluções pessoais.

Por outro lado, o desenvolvimento da personalidade e da inteligência na criança requer a organização e a estruturação do seu mundo interior a partir das suas vivências e experiências que, no início, se mostram por meio de oposições que formam uma unidade: grande-pequeno, aberto-fechado, alegre-triste. É por meio desses contrastes que ela projeta o seu estado interno por meio da racionalidade e afetividade.

O objetivo do estudo da psicomotricidade na criança é conhecê-la a partir de sua atividade motora para assim, desenvolver uma prática pedagógica direcionada a descobrir o que toda ação espontânea traz de simbólico para ela.

$\mathrm{Na}$ criança, a sensório-motricidade se constitui na principal via de expressão de seu mundo interno, organizado por esses contrastes e por essas polarizações de conceitos básicos, especialmente na faixa etária compreendida entre os primeiros meses e os 6 ou 7 anos, etapa na qual a criança se encontra em uma situação de globalidade (união permanente e estreita entre corpo e mente) (SÁNCHEZ; MARTÍNEZ; PENÃLVER, 2003, p.11).

Esta prática pedagógica deve contemplar a maneira como trabalhamos para a organização do pensamento da criança. O contraste, por exemplo, é importante para demarcar limites e definir conceitos. O professor de ensino coletivo, ao trabalhar com crianças na faixa de idade de 6 a 7 anos deve pontuar claramente os contrastes e as oposições que fazem parte do mundo dessa criança.

Trabalhar com os extremos nos ajuda a delimitar o objeto do nosso estudo, que é aprender música por meio do violino. Mostrar os graves e agudos da escala 
musical, as partes menores e os maiores do instrumento, as cordas grossas e as finas, o músculo relaxado e o tenso, a postura correta e a errada, os sons forte e o fraco, a sonoridade do tasto (suave) e a do ponticello (áspera), as notas em legato (sons contínuos) e em staccatto (sons descontínuos), os sons plano e o vibrado, e os coloridos em tonalidades maiores e menores, são alguns dos elementos que sugerimos que se apresentem aos alunos logo no início de seu aprendizado.

Também a postura do professor é marcada por esses contrastes: em alguns momentos haverá a descontração, em outros, a concentração. Sua postura será, por um lado, a de aproximação através da identificação com eles; por outro; a de exigir disciplina e respeito ao seu comando durante a execução dos exercícios. Se deve ser flexível para compreender as diferenças individuais de seus alunos, deve também requerer dedicação e compromisso para com o aprendizado e o estudo do instrumento.

Além da criação desse ambiente pedagógico, o sucesso do ensino coletivo de violino depende também da adoção de uma metodologia que seja específica para o ensino coletivo de cordas. Consistente, didática, objetiva e progressiva, ela deve ajudar o aluno a vencer as dificuldades técnicas e musicais passo a passo.

Essa escolha deve ser feita a partir de um profundo conhecimento do ensino coletivo de cordas, pois o conhecimento da prática instrumental e musical não se dá apenas na esfera cognitiva intelectual, mas também no aprendizado do controle motor que a pessoa adquire pelo estudo contínuo dos movimentos exigidos para o ato de tocar, sendo um aprendizado integral que envolve todos os aspectos do indivíduo, tanto afetivos, cognitivos, quanto físicos. 


\section{ENSINO COLETIVO DE VIOLINO E PSICOMOTRICIDADE}

A pedagogia tradicional do ensino coletivo de violino não contempla todas as dificuldades que rodeiam o aprendizado dos alunos iniciantes. Um dos resultados visíveis é a alta taxa de desistência que ocorre nos grupos de ensino coletivo. Em média, um terço dos alunos que se iniciam desiste no seu primeiro ano de curso e por vários motivos, sendo o principal deles a dificuldade que enfrentam no estudo do instrumento, como desconforto muscular, dificuldades com a leitura musical e com a coordenação dos movimentos no aprendizado do violino.

O conhecimento dos conceitos da psicomotricidade é de grande ajuda para a compreensão dos princípios norteadores dos movimentos em geral e do processo da cognição aliado aos movimentos específicos do violino. Seguimos nossa pesquisa sobre psicomotricidade, relacionando seus conceitos com a pedagogia do ensino coletivo a fim de auxiliar os alunos em sua aprendizagem do instrumento.

A psicomotricidade surgiu como ciência a partir do início do século $X X$, quando vários estudos e pesquisas mostraram a estreita ligação entre o pensamento e 0 movimento. Um dos pesquisadores pioneiros nesse campo foi Henri Wallon ${ }^{6}$ que publicou obras importantes sobre o desenvolvimento da psicologia infantil, como L'Enfant Turbulent, em 1925, e Les Origines du Caractèr Chez l'Enfant, em 1934.

Por ocasião do fim da Segunda Guerra Mundial, o médico psiquiatra Julio de Ajuriaguerra $^{7}$ criou o primeiro serviço de reeducação psicomotora, ao mesmo tempo em que iniciou um trabalho com neuropsiquiatria infantil em Paris, consolidando o conceito de psicomotricidade como a união entre as atividades motora e psíquica:

...psicomotricidade se conceitua como ciência da saúde e da educação, pois indiferente às diversas escolas, psicológica, condutista, evolutista, genética, ela visa à representação e à expressão motora através da utilização psíquica e mental do indivíduo (AJURIAGUERRA apud LOUREIRO, 2010 p.3).

\footnotetext{
${ }^{6}$ Henri Paul Hyacinthe Wallon nasceu em Paris, França, em 1879. Foi médico, psicólogo e filósofo. Wallon foi o primeiro a levar não só o corpo da criança mas também suas emoções para dentro da sala de aula. Fundamentou suas idéias em quatro elementos básicos que se comunicam o tempo todo: a afetividade, o movimento, a inteligência e a formação do eu como pessoa. Disponível em: $<$ http://educarparacrescer.abril.com.br/aprendizagem/henri-wallon-307886.shtml>>. Acesso em: 06 junho 2011.

Julio de Ajuriaguerra, médico psiquiatra, criou o primeiro serviço de reeducação psicomotora, aliada à neuropsiquiatria infantil em Paris. Responsável por consolidar o conceito de psicomotricidade como a união entre as atividades motora e psíquica.
} 
O ato do movimento é visto como parte integrante do comportamento humano, sendo a psicomotricidade a integração de todos os processos superiores dessa motricidade com os processos psíquicos. A psicomotricidade infantil é então a materialização da consciência como resultado da relação entre a criança e o meio em que está inserida. Conforme publicado em Loureiro (2010, p.3), outros pesquisadores definem a psicomotricidade:

A Psicomotricidade como ciência de síntese, que com a pluralidade de seus enfoques procura elucidar os problemas que afetam as inter-relações harmônicas que constituem a unidade do ser humano e sua convivência com os demais. (Dalila M. M. de Costallat)

A Educação Psicomotora é a educação do controle mental e da expressão motora. (Germaine Rossel)

A Psicomotricidade pode ser definida como o campo transdisciplinar que estuda e investiga as relações e as influências, recíprocas e sistêmicas, do psiquismo e da motricidade. (Vítor da Fonseca)

ser humano é visto pela psicomotricidade como um todo indivisível, e seu comportamento e equilíbrio corporal é sustentado por três grandes pilares que promovem a excelência em todos os processos físicos e motores envolvidos:

- Cognitivo: compreende o intelecto e a intencionalidade;

- Afetivo: compreende a relação com o meio ambiente e com o outro indivíduo;

- Motor: compreende o movimento e a gestualidade.

O aspecto cognitivo envolve tanto a cognição quanto o aspecto psíquico, ou seja, corresponde ao fato de saber como fazer o movimento requerido. $O$ comportamento no domínio cognitivo é caracterizado por aquilo que o organismo faz com a informação de que dispõe. Richard Magill diz:

Essas operações mentais, como a descoberta ou o reconhecimento de informação (cognição); retenção ou armazenamento de informação (memória); geração de informações a partir de certos dados; e tomadas de decisão ou feitura de julgamento acerca da informação são consideradas operações componentes integrais realizadas no domínio cognitivo. (MAGILL, 1984, p.3)

O aspecto afetivo envolve o desejo e a adaptabilidade do sujeito, e corresponde ao querer fazer o movimento. O domínio afetivo dos comportamentos é muito importante para a aprendizagem de habilidades motoras, pois inclui aspectos como motivação, interesse, valoração, assim como os comportamentos sociais. 
aspecto motor envolve a prática da ação conjuntamente com a expressão, configurando a capacidade de realizar o movimento. O movimento é a base do domínio psicomotor, pois envolve o componente cognitivo na maioria das habilidades motoras. Elisabeth Simpson, pesquisadora sobre desenvolvimento motor infantil, faz uma classificação das habilidades motoras, partindo das mais simples e evoluindo para as mais complexas:

1. Estimulação sensorial: atuação de um ou vários estímulos sobre um ou mais órgãos dos sentidos.

2. Predisposição: uma prontidão para um tipo particular de ação.

3. Resposta dirigida: o ato comportamental manifesto de um indivíduo sob a direção de um instrutor, no qual o aprendiz tem um modelo ou um padrão pelo qual se pode comparar.

4. Mecanicismo: o aprendiz alcançou certo nível de desempenho quando a resposta é habitual.

5. Resposta complexa manifesta: o indivíduo pode desempenhar um ato motor considerado complexo devido ao tipo de movimento requerido. $\mathrm{O}$ aprendiz atingiu certa habilidade.

6. Adaptação: alteração de atividades motoras para satisfazer às exigências de novas situações problemáticas.

7. Criação: criação de novos atos motores ou modos de manipular os materiais. (SIMPSON, 1974, p.341)

A classificação dos comportamentos em afetivo, cognitivo e motor nos ajuda a desenvolver estratégias de instrução para atingir as metas de ensino planejadas. Porém, cada comportamento requer também a cooperação de outras áreas, assim como tocar violino requer muita atividade cognitiva, embora seja primariamente um comportamento motor na produção da resposta desejada.

Uma das principais bases da psicomotricidade é o estudo do funcionamento do cérebro humano, de como ele envolve todo o nosso ser afetivo, cognitivo e motor. Em nossa pesquisa apresentaremos algumas características da evolução do nosso cérebro de maneira pontual e introdutória, assim como as relações entre a evolução, a maturação do sistema nervoso e sua significação. Não é nosso objetivo fazer uma análise histológica ou uma descrição minuciosa das partes componentes do cérebro, mas discorrer de maneira geral sobre o seu funcionamento naquilo que é pertinente ao foco do presente trabalho.

A evolução da organização humana em sociedades primitivas predispôs o cérebro à construção de novos sistemas funcionais, demonstrando assim a sua grande capacidade em se adaptar a novas necessidades e transformar sua organização interna. A psicomotricidade, por meio do estudo da evolução do cérebro 
humano, estabeleceu fundamentos neurofuncionais, modelos de organização por meio de hierarquias no seu funcionamento e de um complexo sistema de armazenamento e processamento das informações que chegam ao cérebro através dos órgãos da percepção, que são a base e o princípio de todo movimento humano.

Portanto, para compreendermos a gênese de nossos movimentos e suas relações intrínsecas com a parte cognitiva e volitiva, com a intenção particular de entender a origem dos movimentos envolvidos no ato de tocar o violino, precisamos voltar nossos olhos para as questões psicomotoras envolvidas. Dessa forma, compreenderemos a raiz das dificuldades motoras dos nossos alunos e poderemos ajudá-los a se movimentar de forma saudável e livre das tensões.

\subsection{FUNDAMENTOS DA PSICOMOTRICIDADE: O CÉREBRO HUMANO E SUAS FUNÇÕES}

Os fundamentos psicomotores fornecem os parâmetros para cada fase do desenvolvimento motor e neurológico infantil. Tais fundamentos traçam paralelos entre os modelos de organização da vida no planeta, a evolução de todos os seres vivos e o desenvolvimento do nosso cérebro. A psicomotricidade postula que, durante as fases do desenvolvimento do ser humano, ele carrega em seu código genético toda a história da sua evolução. Assim, desde 0 ato da concepção, passando pelo desenvolvimento e mesmo na maturidade, o cérebro continua a funcionar segundo esses parâmetros da evolução na sua organização em hierarquias de funções.

De acordo com Loureiro (2010, p.5), o estudo desses modelos neurofuncionais nos permitirá compreender melhor como nosso cérebro armazena o conhecimento e como emite comandos para a execução dos movimentos. Algumas das principais teorias sobre os fundamentos neurofuncionais da psicomotricidade são:

- Gênese: a origem da vida no planeta. O começo de tudo, a evolução do desorganizado para o organizado; 
- Filogênese: a origem das espécies vivas no planeta, e seu desenvolvimento motor, do rolar até a verticalização da postura humana;

- Ontogênese: a origem do homem desde a fecundação até a idade adulta, para a reprodução;

- Céfalo-caudal: desenvolvimento no sentido da cabeça aos pés;

- Próximo-distal: desenvolvimento no sentido do eixo para a extremidade, do todo para as partes.

A gênese na psicomotricidade se refere à "teoria da panspermia" para explicar os seus princípios fundamentais, os quais demonstram que fenômenos físico-químicos geraram uma aglomeração de poeiras e gases que colidiram em imenso impacto, dando início ao universo conhecido, permitindo a formação de estrelas como o Sol e dos planetas, há cerca de um bilhão de anos (LOUREIRO, 2010, p. 5-6).

Um paralelo é traçado entre a concepção do nosso sistema solar e o desenvolvimento do feto humano, que executa dentro do útero materno movimentos circulares de rotação e translação, como os que executa a Terra em torno do Sol. $O$ ser humano passa das etapas da filogênese às da ontogênese durante todo o processo de seu crescimento e de sua maturação ao vivenciar em sua própria história de desenvolvimento todas as fases evolutivas dos seres vivos no planeta.

O processo da evolução dos seres vertebrados, de acordo com a teoria darwiniana, seguiu uma ordem: primeiro surgiram os peixes, que posteriormente deram origem aos répteis; depois vieram os mamíferos em geral, destacando-se os primatas dentro desse grupo; no final dessa cadeia evolutiva, surgiu o ser humano.

Se não compreendermos a ordem da nossa evolução antropológica e o lugar que ocupamos na natureza, torna-se difícil entender o significado da nossa motricidade, que transcende a função do músculo. Vítor da Fonseca afirma que:

... o cérebro humano não é tanto sensorial, nem motor, mas sim associativo e integrativo, de forma a tornar a motricidade um produto final que possui processos elaborativos complexos. Apesar de desfrutarmos com outros mamíferos formas posturais e motoras similares... porque possuímos estruturas subcorticais próximas, a motricidade humana envolve as áreas associativas integrativas, únicas da espécie. (FONSECA, V. 1995, p. 276) 
A psicomotricidade postula que o homem vivencia todas essas fases evolutivas durante o seu crescimento: dentro do útero materno, ele vive como um peixe ao rolar dentro do meio aquoso; uma vez nascido, passa a rastejar como os répteis; depois, engatinha como os mamíferos; torna-se bípede ou fica de pé como os primatas; por fim, anda com a coluna ereta do ser humano (vide figura 1, a seguir, no sentido horário ascendente).
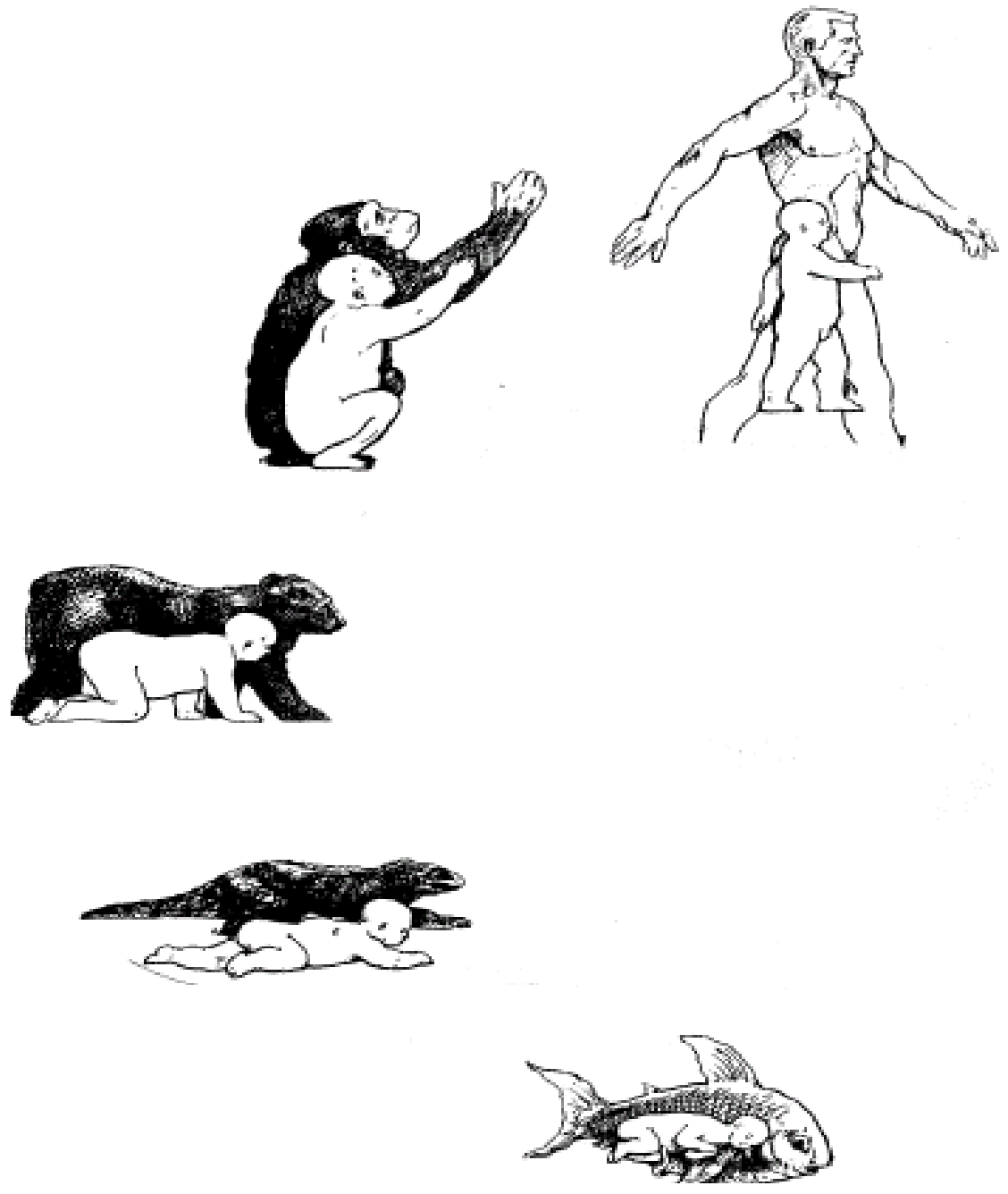

Figura 1 - Da filogênese à ontogênese humana Fonte: Loureiro (2010, p.6)

Os conceitos céfalo-caudal e próximo-distal se referem ao processo de formação da medula espinhal nos seres vertebrados, inclusive do ser humano. Kathleen Haywood e Nancy Getchell examinam essa questão no desenvolvimento fetal:

O estágio fetal, da oitava semana até o nascimento, é caracterizado pelo crescimento adicional e pela diferenciação celular do feto, 
levando à capacidade funcional. Esse crescimento continuado dos órgãos e dos tecidos ocorre... em duas direções. Uma direção é a céfalo-caudal, significando que a cabeça e as estruturas faciais crescem mais rápido; então vem a parte superior do corpo, seguindo-se o crescimento relativamente lento das partes inferiores do corpo. Ao mesmo tempo, o crescimento é próximo-distal na direção, significando que o tronco tende a avançar para as partes mais próximas dos membros e, por fim, para as partes distais dos membros. (HAYWOOD; GETCHELL, 2004, p. 51)

Portanto, a primeira etapa na formação do feto humano é a formação da cabeça; depois, no sentido descendente, forma-se o tronco até chegar às extremidades dos membros superiores e inferiores. Então o sentido da formação do feto é da cabeça para os pés (céfalo-caudal) e do eixo do tronco central para as extremidades das mãos e pés (próximo-distal).

Dessa forma, mesmo que já formado e crescido, o ser humano continua a repetir esses padrões de acordo com os sentidos da formação do tubo neural e do desenvolvimento do feto humano, ou seja, todo processo de apreensão de novos conhecimentos e de aquisição de novas capacidades de movimentação é feito a partir da cabeça em direção aos pés e do tronco para as extremidades.

O cérebro humano, durante o processo de aprendizagem, processa as informações novas, organizando-as e armazenando-as segundo os princípios de sua formação. Por isso, por exemplo, quando se apresenta um novo elemento para um aluno iniciante de violino, como o movimento de tocar em uma corda do violino com todo o arco, desde o talão até a ponta, o cérebro do aluno precisa passar por essas etapas até conseguir processar toda a informação.

O corpo necessita primeiro vivenciar a diferenciação desse movimento dentre todos os possíveis (do caos para a organização); depois conceber o movimento desde o seu nascimento até a sua execução (ontogênese); e então experimentar primeiro os movimentos maiores, executados com o corpo todo até especificar os movimentos mais finos e precisos executados com apenas uma parte do braço (filogênese); finalmente precisa conscientizar sua postura desde a cabeça até os pés (céfalo-caudal) e do tronco até as extremidades (próximo-distal) para poder se manter em equilíbrio.

Ao mesmo tempo, o cérebro humano é capaz de exercer uma multiplicidade de tarefas; porém, quando se trata de aprender um novo elemento, ele se concentra em aprender uma tarefa de cada vez. Edwin E. Gordon afirma: 
It is well understood by educacional psychologists that most students are capable of learning only one concept or one skill at a time. If effective learning is expected to occur, a single concept or single skill must be solidified before another to be combined with it is introduced. (GORDON, 2010, p. IX)

Em tradução livre do trecho citado, Gordon diz que é senso comum entre os psicopedagogos que a maioria dos estudantes seja capaz de aprender somente um conceito ou uma habilidade de cada vez. Se é esperado que um aprendizado efetivo ocorra, um simples conceito ou uma simples habilidade devem ser solidificados antes de outro elemento novo ser introduzido combinado ao anterior. Para compreendermos melhor esse processo, analisaremos os modelos funcionais do cérebro de Luria.

Alexander Romanovich Luria $^{8}$ concebeu, em 1973, um sistema funcional do cérebro que integrava o órgão inteiro, sem zonas delimitadas. Dessa forma, o cérebro humano seria composto por três unidades funcionais básicas, com funções distintas que participariam de toda e qualquer atividade mental, seja no movimento voluntário, seja na atividade da fala ou da escrita.

Luria nos mostra segundo as figuras abaixo, as três unidades funcionais do cérebro humano:

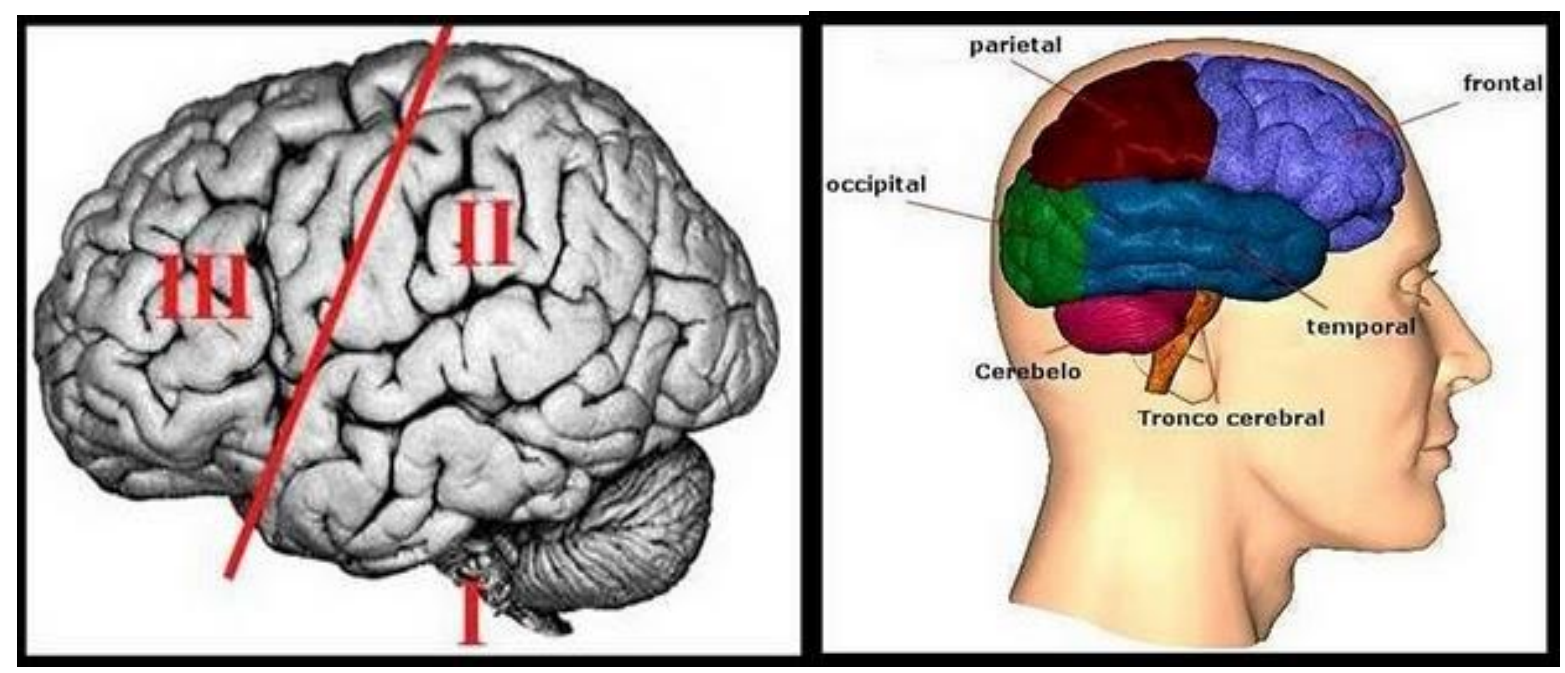

Figuras 2 e 3 - Unidades funcionais de Luria e as funções cerebrais Fonte: Kagan; Saling (1997, p.01)

\footnotetext{
8 Alexander Romanovich Luria (1902-1977) - neuropsicólogo especialista em psicologia do desenvolvimento. Durante a Segunda Guerra Mundial, liderou uma equipe de pesquisa no Hospital do Exército para desenvolver métodos de reabilitação de deficiências orgânicas psicológicas em pacientes com lesões no cérebro. (LURIA, A.R. Autobiography of Alexander Luria: A Dialogue with the Making of Mind. USA, Lawrence Erlbaum Associates, Inc, 2005.)
} 
- Primeira unidade funcional engloba: a medula, o cerebelo, o tálamo e tem a função de regulação do tônus cortical e de vigilância;

- Segunda unidade funcional engloba: o córtex cerebral, os lóbulos parietal, occipital e temporal, e atua com a função de captação, processamento e armazenamento da informação do mundo exterior;

- Terceira unidade funcional engloba: o córtex motor e lóbulos frontais, e atua com a função de programação, regulação e verificação da atividade mental.

A primeira unidade funcional cuida da integração dos órgãos sensoriais, o controle motor fino, a regulação de toda atividade mental, a coordenação das informações sensorial com a motora e o controle dos movimentos involuntários. Ela corresponde ao modelo do cérebro reptiliano, ou o mais primitivo dos cérebros, que segundo Fonseca (1995, p.62):

...constitui o cérebro mais antigo, que inclui as estruturas responsáveis pelos comportamentos mais elementares, mas também os mais vitais, como os que medeiam as funções do sono, vigilância, atenção e alerta. Está também envolvido... nas respostas reflexas, que, como sabemos, sofrem uma hierarquização progressiva, dos invertebrados aos vertebrados e, dentro desses, dos peixes ao homem.

A segunda unidade funcional cuida da integração dos estímulos dos órgãos da visão, da audição e das funções táteis cinestésicas ${ }^{9}$. Cuida da recepção dos estímulos que circulam no cérebro para depois serem encaminhados para o processamento e a síntese dos resultados.

A terceira unidade funcional é responsável pela programação e verificação da informação captada pela segunda unidade funcional, onde ocorre a organização da atividade consciente. $O$ desenvolvimento e o aperfeiçoamento da motricidade humana estão associados à formação dessas áreas terciárias. Outras funções que destacamos dessa terceira unidade funcional são as funções da linguagem e as funções associativas cognitivas superiores, como a formação de conceitos, a

\footnotetext{
${ }^{9}$ Cinestesia (ou quinestesia, kinestesia): sentido da percepção de movimento, peso, resistência e posição do corpo provocado por estímulos do próprio organismo. Homônimo de sinestesia. Dicionário Houaiss da Língua Portuguesa, p. 467.

Nota da autora: Não confundir com sinestesia: cruzamento de sensações; associação de palavras ou expressões em que ocorre combinação de sensação ou percepção simultânea. Dicionário Houaiss da Língua Portuguesa, p. 1749.
} 
organização de dados e sua sequência lógica, as estratégias complexas da percepção, da pesquisa e da resolução de problemas.

Nosso cérebro trabalha de maneira hierárquica com as unidades funcionais. $A$ formação de áreas terciárias só acontece depois das secundárias, que por sua vez só são formadas após as áreas primárias. Isso mostra a hierarquia da experiência sobre a formulação teórica, pois primeiro temos a sensação da percepção e da imagem, vindo depois a formação de conceitos e a transformação em símbolos.

O cérebro de um adulto entende e transforma o mundo em sistemas lógicos e esquemáticos. Por isso, a evolução dos processos cerebrais se dá no sentido vertical: primeiro vem o pensamento e depois, o ato. Wallon (1969) postula que na criança, cujo cérebro está em formação, esse sentido de desenvolvimento é invertido, pois ela vivencia em primeiro lugar as experiências que sua percepção oferece, para só depois as organizar em formulações de conceitos. Então, seu sentido de desenvolvimento vai do ato para o pensamento.

Posto isso, em relação ao ensino do violino, constatamos a importância de se oferecer à criança muitas oportunidades de vivenciar o ato de tocar o instrumento, em diferentes contextos e com diversos elementos. Dessa forma ela será estimulada ao máximo em sua percepção musical e sua parte motora.

Essa vivência múltipla tem como objetivo criar o maior número possível de experiências, ou seja, diversos tipos de conexões neuronais para que a gama de possibilidades de acesso ao controle motor seja a maior possível. Isso é possível por meio de exercícios preparatórios, que são realizados mesmo sem o instrumento em mãos, que apresentaremos em maior profundidade no capítulo 3.

Todo movimento humano apoia-se em duas bases complementares: o planejamento e a execução. A construção dos movimentos ocorre a partir da preparação de fatores posturais e motores, tais como a tonicidade, que devem ser incorporados em programas de preparação dos movimentos no cérebro para só então serem enviados para os órgãos e músculos periféricos. Depois da preparação, que é a antecipação desse movimento voluntário consciente, é que os comandos podem ser enviados e originar os movimentos necessários. Sobre esse assunto, Bernstein (1967) ${ }^{10}$ afirma que todo e qualquer movimento se organiza com uma

\footnotetext{
${ }^{10}$ Nikolai Aleksandrovich Bernstein (1896-1966) estudou os movimentos com a finalidade de entender o cérebro. Ao contrário de Pavlov, ele enxergava os movimentos (e o cérebro) como coordenados. (BERNSTEIN, N. A. The Coordination and Regulation of Movements. Oxford:Pergamon Press, 1967)
} 
finalidade específica. Como consequência disso, surgiu a necessidade natural da programação antecipada da ação, ao mesmo tempo em que se estruturava o desenvolvimento da linguagem.

O pensamento reflexivo é a origem dessa cadeia dinâmica de comando e controle em que se baseia a antecipação do movimento. A coordenação dos movimentos é uma organização dessas ações motoras em função de um objetivo antecipado, evidenciando uma relação entre a consciência e a ação. Para isso, é necessário:

- Programar previamente o comportamento, ou seja, estabelecer uma relação entre a ação e a situação, fixar a finalidade na memória e controlar a ação;

- Analisar os efeitos e relacioná-los com as intenções originais.

Uma vez ocorrida a ação, se o resultado do movimento foi atingido, os tônus cortical (processamento da ação no cérebro) e postural (preparação do corpo para a ação) relaxam e a atividade se encerra. Caso contrário, os tônus corticais e corporais aumentam para continuar a ação até atingir o objetivo previsto.

Portanto, a realização de um movimento voluntário envolve um plano consciente interior, no qual as informações sobre que partes do corpo devem se mover, a direção e a trajetória dos movimentos e o número de movimentos isolados são armazenados numa memória prévia na terceira área funcional do cérebro.

Além disso, para que o movimento ocorra, é necessário que se crie uma visualização interna do espaço no qual o movimento se dará. Essa matriz espacial é criada pela segunda unidade funcional, especificamente na zona das terminações visuais. Se, por acaso, essa área estiver danificada, o esquema espacial do movimento se perde e, como consequência, o movimento não atingirá seu objetivo.

Em seguida, é necessário que os órgãos do movimento enviem impulsos constantes, para indicar a posição do corpo e suas extremidades no espaço, com a finalidade de coordenar o movimento. Além disso, requer a cooperação de todos outros órgãos que fornecem a ligação de um movimento ao outro, formando um plano sucessivo de movimentos que fazem parte do padrão do movimento como um todo.

A recepção de um objeto pelo cérebro ocorre por meio de vários canais de entrada dos órgãos sensoriais e está inseparavelmente baseada no movimento. A visão, o tato e o sentido cinestésico trabalham juntos nas suas análises e síntese, ao mesmo tempo em que o objeto físico é transformado em objeto mental. Sobre isso, 
Piaget (1956) declara que a percepção tem lugar através da ação, e a ação combinada das três unidades funcionais, por meio de sua organização, permite atingir as formas mais complexas de atividade psíquica superior.

Dessa forma, todo movimento que um aluno realiza no ato de tocar o violino deve ser consciente de sua finalidade. Essa conscientização implica uma explicação verbal do objetivo final de determinado movimento, sua relevância musical e sua conexão com outros movimentos secundários. Além disso, o aluno precisa antecipar o movimento por meio de uma visualização espacial mental dele. O próximo passo é se conscientizar dos dados de seu equilíbrio corporal e do tônus muscular para dosar a força e o peso necessários nos membros para coordenar o movimento.

Todas as três unidades funcionais trabalham conjuntamente por meio de processos de interação, em que cada uma fornece sua contribuição específica ao todo complexo da atividade mental. No processo de aprendizado e domínio de uma nova habilidade ou conceito, ocorre uma hierarquização no processamento desta informação, de modo que, em primeiro lugar vem a percepção sensorial e motora que participam da primeira unidade funcional, para depois a informação ser organizada e processada pelas outras unidades funcionais.

Podemos concluir desta forma, a precedência da prática sobre a teoria, pois em primeiro lugar vem a percepção pelos canais sensório-motores, que servirá de conteúdo para o processamento nas instâncias reflexivas mentais, sem as quais não haveria conhecimento de fato. O aluno aprende a tocar, em primeiro lugar, pela experimentação motora dos movimentos, e depois pela organização teórica e conceitual desta informação.

O aprendizado não ocorre sem a prática, e a prática instrumental inclui a imitação dos movimentos no período inicial do aprendizado. Porém se o aluno não aprender a refletir sobre o ato que realiza, em um segundo momento, também não será capaz de corrigir seus erros, nem buscar novas perspectivas para sua execução.

É em meio a essa perspectiva que analisaremos a seguir a estrutura dos processos psicomotores, especialmente na criança, baseada no modelo de observação dos fatores psicomotores e teorias de desenvolvimento motor elaborada por autores como Vitor da Fonseca e Richard Magill, assim como em seus fundamentos metodológicos. 


\subsection{ASPECTOS GERAIS DO DESENVOLVIMENTO PSICOMOTOR INFANTIL}

O cérebro humano desenvolve três tipos de comportamento, os inatos como as funções fisiológicas básicas; os que são aprendidos e que compartilhamos com outros mamíferos, como a significação básica dos dados da percepção; e aqueles que são aprendidos, mas que não repartimos com mais nenhuma outra forma de vida, como as praxias ${ }^{11}$, o trabalho, a linguagem falada e escrita, a autoconsciência, o pensamento abstrato e os valores.

Esses comportamentos atuam durante toda nossa vida, antes e depois do nascimento, e todas as aprendizagens e funções psíquicas superiores são modificações desses mecanismos mais primitivos. Para compreendermos o desenvolvimento do cérebro da criança e seus padrões de funcionamento, devemos antes de mais nada, partir do estudo daqueles comportamentos que não repartimos com mais nenhuma outra espécie, ou seja, aqueles que pertencem exclusivamente ao ser humano.

O comportamento infantil é, antes de tudo, resultado dos valores de sua cultura e sua história, e é por meio desse envolvimento social que ela consegue alcançar sua autoconsciência, ou a percepção de si mesma como indivíduo, antes de passar pela fase da simbolização.

A criança constrói a base de seu processo de comunicação e de significação a partir do envolvimento que tem com as aprendizagens que ocorrem desde a primeira infância.

Segundo a pesquisa de Vygotsky ${ }^{12}$ (1962), o desenvolvimento mental da criança não é apenas um amadurecimento dos "instintos naturais", ela se desenvolve no processo da atividade objetiva e na comunicação com os adultos, com quem aprenderá a práxis ${ }^{13}$ e a linguagem humana.

\footnotetext{
${ }^{11}$ Praxia: ação particular; o modo de agir próprio de um indivíduo (Dicionário Houaiss da Língua Portuguesa, p. 1536).

${ }^{12}$ Lev Semenovitch Vygotsky, psicólogo experimental bielo-russo, foi um pensador importante em sua área, pioneiro na noção de que o desenvolvimento intelectual das crianças ocorre em função das interações sociais e condições de vida. Todas as suas construções teóricas têm os experimentos como seu ponto de partida. Disponível em: <<http://www.dfi.ccet.ufms.br/prrosa/Pedagogia/Capitulo_5.pdf, pg. 3>>. Acesso em: 10 abril 2012.

Práxis: prática, ação concreta; parte do conhecimento voltada para as relações sociais e as reflexões políticas, econômicas e morais. (Dicionário Houaiss da Língua Portuguesa, p. 1537).
} 
A criança aprende a controlar os objetos que foram desenvolvidos na história humana e aprende a utilizar meios externos e sinais para vir a organizar melhor o seu próprio comportamento... para que 0 desenvolvimento do cérebro opere, não basta a simples exposição a fontes de estímulo, é necessário um agente de mediação (FONSECA, V. 1995, p.50)

O cérebro infantil amadurece a partir do contato com o adulto, que servirá de mediador, por meio do qual aprende a linguagem e consegue desenvolver o seu cérebro, organizar seu comportamento e se ajustar ao seu meio social. No início do seu desenvolvimento, a atividade da criança é regulada pela linguagem exterior do adulto, que mais tarde é interiorizada por ela numa linguagem própria, que vai servir de guia e organizar a atividade de seu próprio cérebro.

Sobre o surgimento da linguagem e sua relação com a inteligência, J. Piaget (1964) postula que a linguagem não é suficiente para explicar o pensamento, porque as estruturas que o caracterizam têm as suas raízes na ação e nos mecanismos sensório-motores.

A formação da linguagem está intimamente ligada à ação, ou seja, a partir do movimento e do desenvolvimento dos mecanismos de percepção é que o cérebro passou a estruturar o pensamento. Podemos inferir, portanto, que é a partir do movimento que o cérebro aprende a pensar, sendo por isso, fundamental que o aluno realize os movimentos dos exercícios preparatórios, antes de efetivamente tocar no instrumento, para que o cérebro aprenda os movimentos e estruture essas relações entre o movimento corporal e o ato requerido na execução musical. Dessa maneira, o cérebro aprende a "pensar" o ato de tocar violino a partir dos movimentos preparatórios.

Observando a evolução humana, desde os primórdios até o homem atual, Vítor da Fonseca (1995, p. 51) afirma que antes que:

exibisse qualquer inteligência manual (inteligência motora), foi necessário que se dessem várias libertações anátomo-morfológicas, que conduziram à organização interior do cérebro.

A mais importante dessas modificações ocorridas foi a separação e a oposição entre os dedos polegar e indicador na estrutura da mão humana. Essa inovação evolutiva foi responsável pelo início da construção da inteligência humana, demonstrando que a motricidade humana está intrinsicamente ligada ao desenvolvimento da nossa linguagem. 
Essa relação entre a motricidade e o desenvolvimento da inteligência mostra que a prática de movimentos específicos nos leva a realizar novos tipos de conexões neuronais e, consequentemente, alargar nossa capacidade associativa e de raciocínio. Disso decorre a importância de se adotar várias abordagens de ensino, ou seja, ensinar o aluno a compreender o processo de apreensão de determinado conteúdo, pois muitas vezes é necessário apresentar o mesmo conteúdo de diversas maneiras para que o aluno amplie sua gama de relações neuronais, o que facilita o aprendizado.

Tomemos um objetivo pedagógico como, por exemplo, posicionar a mão direita no arco. Constatamos que a apresentação de diversas maneiras de chegar ao mesmo resultado favorece a experimentação por parte do aluno e amplia suas possibilidades de acerto, uma vez que a motricidade e a sua prática constroem de maneira concreta o seu conhecimento e estruturam melhor a sua capacidade de raciocínio sobre o assunto.

O cérebro se estrutura de maneiras diferentes durante o desenvolvimento e a maturação do ser humano. Na criança, a formação dos centros superiores nos quais estão as funções mais complexas de elaboração do pensamento depende da maturidade dos centros inferiores, que acomodam as funções da percepção, enquanto que no adulto, os centros superiores organizam e influenciam os inferiores. No adulto, é o pensamento que comanda os órgãos de locomoção e organiza os dados provenintes de sua percepção sensorial, enquanto que na criança, o pensamento está sendo formado enquanto chegam os estímulos da percepção.

Por isso, é mais pertinente ainda a questão de se estimular musicalmente as crianças e incentivá-las a explorar o violino como objeto lúdico e instrumento musical o mais cedo possível. Desse modo, criam-se novas estruturas cerebrais por meio da experimentação manual e dos sentidos da percepção da criança, enquanto que no adulto, esses circuitos de resposta neuronal já estão consolidados, e são apenas adaptados a uma nova tarefa na aprendizagem do instrumento.

A formação de novas conexões cerebrais em resposta ao estímulo musical na criança, abre novos caminhos para a informação e a reação motora ao se praticar o ato de tocar, que é incorporado aos movimentos naturais do seu corpo, em vez de ser somente uma adaptação de outros movimentos e conexões . 


\subsection{FATORES PSICOMOTORES APLICADOS AO ENSINO COLETIVO DE VIOLINO}

O processo da aprendizagem do violino envolve o domínio de vários aspectos da coordenação motora e do conhecimento do próprio corpo. Quando uma criança inicia sua aprendizagem motora no instrumento, a primeira etapa deste processo é conhecer a terminologia básica das capacidades, habilidades e padrões de movimentos que está aprendendo. Desta forma, ela aprofundará o seu entendimento sobre o próprio movimento e terá a oportunidade de aprender a refletir sobre $\mathrm{o}$ ato que está realizando.

Todo ato motor pode ser considerado uma habilidade, e apresenta uma propriedade particular que precisa ser aprendido para poder ser executado corretamente. Por exemplo, o andar, embora seja uma habilidade fundamental e relativamente simples, exige aprendizagem da criança que passa por vários estágios desde 0 rolar, o engatinhar até conseguir realizar propriamente 0 ato de andar. Segundo Richard Magill:

Podemos definir, então, habilidade neste contexto quando relacionada especificamente a habilidades motoras, como aqueles atos ou tarefas que requerem movimento e devem ser aprendidos a fim de serem executados corretamente. (MAGILL, 1984, p.9)

Ao estudarmos o desenvolvimento motor das crianças, observamos que seu padrão de movimento envolve ações motoras completas, com a utilização de vários grupos musculares do corpo. Esses movimentos completos constituem a estrutura básica de certas habilidades motoras específicas, daí a importância de entendermos tais padrões. $O$ ensino do violino deve ser focado nos padrões do movimento global da criança e não apenas nos movimentos dos braços e dedos, pois é a partir dos padrões de movimentação dos grandes grupos musculares que provém a movimentação específica dos dedos das mãos, por exemplo. Godfrey e Kephart (1968, p. 37), em seu livro Movement Patterns and Motor Education, definem padrão de movimento como:

... um grupo amplo ou séries de atos motores desempenhados com graus menores de habilidade... mas que são dirigidos à realização de alguma meta externa (em tradução livre). 
Habilidades motoras diferentes podem ser complementares para a execução de determinado movimento, e é necessário que o professor compreenda os pontos de semelhança e diferença entre elas para planejar a instrução do seu aluno. $O$ ato de puxar o arco desde o talão até a ponta, por exemplo, requer a combinação de várias habilidades e padrões de movimento que são seqüenciais. Isto é, um certo número de movimentos distintos deve ser executado em uma seqüência específica para que a tarefa de tocar possa ser desempenhada. Se qualquer parte dos movimentos é esquecida ou se a seqüência de movimento estiver fora de ordem, a ação não será bem sucedida.

A aprendizagem motora pode ser definida então, como uma mudança interna na criança, a partir da melhoria apresentada pelo seu desempenho do movimento como resultado da prática, em caráter duradouro.

Quando um aluno iniciante começa a adquirir uma habilidade nova, geralmente se defronta com os problemas de ordem cognitiva em primeiro lugar. Perguntas sobre como segurar o violino e o arco, onde posicionar cada mão e dedos, como fazer para tocar as notas musicais, além das questões teóricas sobre a leitura e a compreensão da linguagem musical são algumas das indicações de que ele se encontra no início da aprendizagem dessa habilidade específica.

No livro Human performance, os pesquisadores Fitts e Posner (1967) postulam um modelo de aprendizagem motor em três estágios. O primeiro estágio é o cognitivo, que envolve uma grande quantidade de atividade mental ou intelectual.

Nesse estágio, o principiante comete erros grosseiros, como escorregar com o arco fora da corda, não conseguir sustentar o violino ou o arco na posição correta, não conseguir tocar em apenas uma corda sem esbarrar em outras. O seu desempenho tende a ser bastante inconsistente, pois embora saiba que está fazendo algo errado, geralmente não sabe exatamente o que fazer para mudar. Por isso, necessita de informação específica do professor, para mostrar-lhe o que está acontecendo, ajudá-lo a compreender em que está errando e como corrigir seu movimento.

O segundo estágio de aprendizagem é chamado de estágio associativo. Nesse estágio alguns elementos ou mecanismos do movimento foram parcialmente aprendidos, e os erros são menos frequentes. O aluno passa a se concentrar em refinar sua habilidade e a desenvolver maior controle dos seus movimentos, pois aprendeu a identificar alguns dos seus erros ao tocar no instrumento. Isso permite o 
estabelecimento de metas e diretrizes sobre sua prática, mesmo que ainda imperfeita.

No terceiro estágio, chamado por Fitts e Posner de estágio autônomo, a habilidade se torna quase automática e passa a ser habitual. $\mathrm{O}$ aluno não precisa mais dispender atenção para a execução completa dos seus movimentos, pois aprendeu a desempenhar quase toda a ação de tocar violino sem pensar mais nela. Nessa fase, o aluno desenvolve a capacidade de detectar seus próprios erros e passa a realizar os ajustes necessários para corrigí-los, ao mesmo tempo em que seu desempenho se torna mais regular.

E este é o objetivo do ensino coletivo de violino: conduzir o aluno principiante, por meio de muito treinamento e estudo, por todas essas etapas do aprendizado até chegar ao estágio autônomo, para que ele consiga tocar musicalmente o instrumento sem ter de se concentrar apenas nos movimentos ou na técnica. Dessa forma, o aluno estará livre para dar atenção a outros aspectos de interpretação e compreensão musicais que the asseguram um desempenho musicalmente amadurecido e mais perfeito.

O estudo dos fatores psicomotores é o ponto de partida deste processo, pois nos permite traçar o perfil da organização psicomotora das crianças na nossa faixa etária eleita dos 6 aos 12 anos de idade, e nos ajuda a compreender suas dificuldades e facilidades no processo da aprendizagem.

Observamos que a identificação de sinais psicomotores não substitui um exame neurológico, pois não possui informação suficiente para apurar um diagnóstico neurológico específico, e também não substitui os exames psicológicos padrões, mas nos ajudam a observar a personalidade psicomotora da criança.

Os sete fatores psicomotores básicos estão organizados segundo o modelo de Luria. Sua maturação acontece de acordo com a linha cronológica do crescimento da criança e seu desenvolvimento ocorre em idades específicas, após os quais detectamos faltas ou falhas psicomotoras (FONSECA, V.1995, p. 104-105):

1. Tonicidade: do nascimento aos 12 meses de idade.

2. Equilibração: dos 12 meses aos 2 anos de idade.

3. Lateralização: dos 2 aos 3 anos de idade.

4. Noção do corpo: dos 3 aos 4 anos de idade.

5. Estruturação espaço-temporal: dos 4 aos 5 anos de idade. 
6. Praxia global: dos 5 aos 6 anos de idade.

7. Praxia fina: dos 6 aos 7 anos de idade.

A seguir analisaremos cada um destes fatores psicomotores com maiores detalhes.

\subsubsection{Tonicidade}

A tonicidade desempenha uma função primordial de alerta e vigilância, sem as quais nenhuma atividade mental pode ser realizada. Ela envolve a atenção e a concentração, e tem relação direta com a equilibração que é a base da coordenação motora. Ela reflete o primeiro degrau de maturidade neurológica do ser humano, suportando o peso do corpo e preparando o desenvolvimento postural e da preensão manual sem a qual, seria impossível segurar um lápis ou um arco de violino de forma adequada.

Segundo Le Boulch (1982), a criança desenvolve sua tonicidade por meio de aquisições neuromusculares, percepção tátil e integração de padrões motores de equilíbrio. A atividade fundamental do músculo é a contração que constitui a base de todas as atividades motoras e posturais, principalmente preparando o movimento, mantendo a estática e o equilíbrio.

Vítor da Fonseca (1995, p.121) diz que a tonicidade é de importância fundamental para o desenvolvimento motor e psíquico da criança:

... o fator da tonicidade é o seu alicerce fundamental. A tonicidade garante, por consequência, as atitudes, as posturas, as mímicas, as emoções, etc. de onde emergem todas as atividades motoras humanas.

O estudo do tônus expõe vários problemas, pois ao analisarmos o deslocamento de uma parte do corpo, é extremamente difícil distinguir a partir de que momento esse deslocamento foi ocasionado por uma variação do tônus, ou por um movimento voluntário. Ainda segundo Le Boulch (1982), é impossível pensar que a ação seja resultado de apenas um músculo isolado, porque na verdade ela é resultante de uma multiplicidade de condições da situação e de fatores espaço-temporais. 
Essa ligação intrínseca de todos os músculos e sua ação concatenada nos remete à visão do corpo como unidade indivisível no estudo do violino. Rolland e Mutscheler (1974, p.32) comentam esse enfoque nas aulas de violino:

The older concept of the arm performing the bowing is being replaced now by the concept of the body performing this function. It seems to us more useful not to think any more in terms of a right and left hand technique, but rather of an entire body technique.

Em tradução livre, Rolland diz que a antiga concepção do braço tocando o arco é agora transformada na concepção do corpo atuando nessa função. É mais produtivo não pensar em termos de técnicas de mão direita e de mão esquerda, mas da técnica que envolve o corpo todo.

É impossível separar a motricidade da tonicidade, assim como não é possível separar postura do movimento voluntário. Também a motricidade é composta por uma sucessão de tonicidades, e a soma das tonicidades compõe a equilibração humana.

Julio Ajuriaguerra postulava a idéia de que o estudo do tônus nos permitiria definir a propensão de uma criança à hipotonia ou hipertonia.

A criança hipotônica, de baixa tonicidade muscular, é mais extensível ou flexível. Ela é em geral mais calma, suas atividades motoras mais tranquilas, e o seu desenvolvimento postural é normalmente mais lento que o das crianças hipertônicas. Um perfil de hipotonia se apresenta frequentemente no sexo feminino, caracterizado por uma predisposição motora voltada para questões da preensão e das praxias finas. Por isso, suas atividades mentais são em geral mais elaboradas, reflexivas e controladas. Nos casos em que a hipotonia é excessiva, a criança aprensenta um quadro de passividade, com pouca atividade motora, descoordenação, flacidez e moleza muscular.

A hipertonia é mais característica do sexo masculino. A criança hipertônica apresenta alta tonicidade muscular, é menos extensível, mais ativa e tem um desenvolvimento postural mais precoce; daí sua predisposição para a marcha e para a exploração do espaço. Como consequência disso, suas atividades mentais surgem mais impulsivas, dinâmicas e por isso, mais descoordenadas e desorganizadas. Em um quadro de hipertonia excessiva, a criança apresenta falta de flexibilidade, hiperatividade, impulsividade, instabilidade, distração extrema, imprecisão na aplicação da força, alta velocidade nas atividades e falta de controle dos movimentos. 
Com as crianças hipotônicas, o professor deve sempre ensinar os movimentos básicos do instrumento divididos em etapas, mostrando-lhes como um movimento complexo pode ser dividido em vários movimentos mais simples, e explicando-lhes os princípios de cada um deles, com a finalidade de desenvolver tanto a parte intelectual que é naturalmente mais estimulada nessas crianças, como o domínio dos movimentos de preensão e controle motor, que necessitam ser mais estimulados nesses casos. Dessa forma, uma criança hipotônica que tem dificuldade em sustentar o braço esquerdo sob o violino, por exemplo, pode fortalecer os músculos do braço através de movimentos rotatórios mais simples, até chegar a dominar a mudança de posição e técnica de vibrato sem perder força ou sustentação.

Já com as crianças hipertônicas a abordagem do professor deve ser oposta à das hipotônicas, pois enquanto as crianças hipotônicas são mais tranquilas e têm maior grau de atenção e concentração, as hipertônicas são agitadas e não aguentam ficar muito tempo paradas. Por isso a explicação do professor deve ser rápida e objetiva, e o mais recomendado é não se deter em detalhes e, ao mesmo tempo, permitir que as crianças explorem por si mesmas o assunto a ser estudado. Uma aula dinâmica e que apresente novas atividades constantemente é uma forma de manter o interesse e a atenção dos alunos hipertônicos. Exercícios de extensibilidade dos membros e com maior movimentação corporal são recomendados para os hipertônicos conseguirem relaxamento muscular, assim como exercícios ritmados os ajudam a manter a pulsação rítmica.

\subsubsection{Equilibração}

A equilibração é fundamental para a harmonia corporal, e é responsável pela nossa capacidade de atenção e concentração. Por conta dela, o ser humano conquistou a postura bípede, a segurança gravitacional e desenvolveu seus padrões locomotores. A equilibração é condição básica para a organização psicomotora, pois envolve uma multiplicidade de ajustamentos posturais que dão suporte aos nossos movimentos. Reúne um conjunto de aptidões estáticas e dinâmicas, que garantem o controle postural. 
O equilíbrio na infância melhora dos 3 aos 19 anos em uma variedade de tarefas. Haywood e Getchell (2004, p. 222-223) apontam que:

Tem sido observado que, em crianças de 4 a 6 anos, ocorre regressão em testes de plataforma de movimento. Mudanças no crescimento físico, tais como mudanças na proporção de massa de membros e tronco, não parecem contribuir para isso, levando à suspeita de que trocas de dependências em diferentes sistemas perceptivos estão envolvidas. Quando as crianças têm entre 7 e 10 anos, contudo, elas mostram respostas posturais do tipo adulto.

Quando muito pequenas, antes dos 3 anos, as crianças dependem mais do sistema visual para estabelecer seu equilíbrio do que o senso tátil cinestésico. Mas à medida que crescem, por volta dos 6 a 7 anos, essa dependência muda, e elas passam a depender mais da informação cinestésica do que da informação visual para o seu equilíbrio.

Para a manutenção do equilíbrio durante a locomoção, os autores Assaiante e Amblard (1995, p.13-43) propuseram um modelo dividido em quatro períodos:

- Primeiro período, desde o nascimento até ficar em pé, é caracterizado pela direção céfalo-caudal do controle muscular.

- Segundo período, do andar até cerca de 6 anos de idade. Ocorre o domínio da coordenação dos membros inferiores e superiores.

- Terceiro período, dos 7 anos de idade até a adolescência, é caracterizado pelo refinamento da estabilização da cabeça no controle do equilíbrio.

- Quarto período, na idade adulta e é caracterizado pelo controle refinado e livre da movimentação do pescoço.

Dessa forma, durante a infância, a criança passa por diferentes estágios na sua equilibração e por diferentes referenciais de apoio, do visual ao cinestésico.

O professor de ensino coletivo deve levar em consideração esses estágios ao planejar suas aulas, pois para crianças pequenas até a idade de 6 anos, a informação sobre o uso do equilíbrio corporal para executar o ato de tocar deve se basear mais em modelos visuais do que de tato ou de transferência de peso. Imagens visuais são de grande ajuda na explicação de como se deve posicionar o arco, por exemplo, sobretudo quando acrescida de elementos lúdicos familiares à criança.

A partir dos 7 anos, a criança apresenta resposta idêntica à do adulto, na manutenção de seu equilíbrio corporal, embora seu controle motor ainda esteja 
incipiente. O entendimento sobre o sistema de alavanca que o braço direito executa ao posicionar o arco na corda pode ser explicado por meio de experiências com as sensações de peso e de equilíbrio corporal, por exemplo, ao efetuar movimentos rotatórios com o braço inteiro, aproveitando o movimento da inércia exercido pelo peso do braço para efetuar o giro.

O grande desafio para a criança, ao passar por esses períodos do seu desenvolvimento motor, é aprender como os diferentes tipos de referência se complementam durante o movimento e assim desenvolver sua equilibração.

\subsubsection{Lateralização}

Compreende os conceitos de dominância lateral e de lateralidade. A dominância lateral diz respeito à preferência por um dos lados do corpo como dominante, como o hemisfério cerebral, uma das mãos, um dos pés, olhos e ouvidos. A lateralização diz respeito aos conceitos de direita e esquerda, fundamentais para o processo de aprendizagem formal, uma vez que são necessários para todo tipo de aprendizagem como a leitura, a escrita, o pensamento matemático e a direção na movimentação corporal.

A relação de direita e esquerda foi fundamental na história da humanidade para a construção da civilização, pois sem o domínio de uma direcionalidade, não haveria a possibilidade da aprendizagem simbólica e da expressão escrita da comunicação. Enquanto a relação em baixo e em cima é relativamente de simples compreensão para a criança por meio do movimento de flexão dos joelhos, assim como a relação frente e atrás, que também é dada pela visão do entorno, a relação direita e esquerda é uma relação de difícil assimilação, pois envolve uma construção simbólica. Vítor da Fonseca afirma que:

... é necessário que a criança simbolize o seu corpo. Essa simbolização do corpo em si e no envolvimento é vital à aprendizagem humana e essencial à evolução coginitiva da criança... a lateralidade não é um dom que se transmite geneticamente, é uma construção psíquica, elaborada através de uma motricidade corticalizada. (FONSECA, V. 1995, p.301) 
Na dominância cerebral, a especialização dos hemisférios está intimamente ligada à evolução do trabalho humano. Vítor da Fonseca também afirma que:

No ser humano a preferência pela lateralidade manual direita é superior à mista em $33 \%$, e essa é superior à manual esquerda em $26 \%$... O fato de a distribuição humana pender para a direita reflete uma influência sistemática de algo mais importante que a teoria do acaso, que leva os seres humanos a uma especialização hemisférica, induzindo a uma realização de tarefas mais eficazmente por cada um dos lados do cérebro: o hemisfério direito mais eficaz no processamento de padrões espaciais e rítmicos; o hemisfério esquerdo mais eficaz no processamento de padrões verbais e lógicos. (FONSECA, V.1995, p.78)

A preferência manual destra permitiu a evolução do cérebro, pois cada mão se especializou em uma atividade específica, enquanto uma exercia o papel da iniciativa, a outra realizava a função de suporte. Essa complexa integração neurológica permitiu a especialização dos dois hemisférios cerebrais e o surgimento da linguagem, que está relacionada à lateralização das funções cerebrais.

Não há, no entanto, um estudo científico que determine a relação necessária entre a dominância da mão com o uso do arco ou do violino. O uso convencional é de colocar o violino sobre o ombro esquerdo e mantê-lo seguro por meio de um tripé formado pelo ombro, pelo queixo (lateral da mandíbula esquerda) e pela mão esquerda no braço do violino, enquanto que é convencionado segurar o arco com a mão direita.

Mesmo sem um determinante conhecido pela preferência do arco ser posicionado na mão direita, podemos considerar a hipótese da grande porcentagem de destros na população desde o início da civilização ser uma causa dessa preferência, já que o arco é responsável por grande parte da produção sonora do instrumento, e pelas dinâmicas musicais como forte (f) e piano (p), ou seja, pela produção de sons mais fortes ou mais fracos.

Essa produção de som pelo arco está relacionada ao uso de maior força e deslocamento do peso do braço sobre as cordas do violino, o que nos leva a acreditar que está vinculada ao uso da mão dominante, que nesse caso, é a destra para a maioria da população. Essa convenção é conhecida desde os primórdios da história do instrumento, como mostram várias pinturas antigas sobre músicos com o violino ou seu antecessor, a viola da gamba, sempre retratados com o arco na mão direita e o instrumento seguro na mão esquerda, como pode ser visto nas Figuras 4 e 5. 


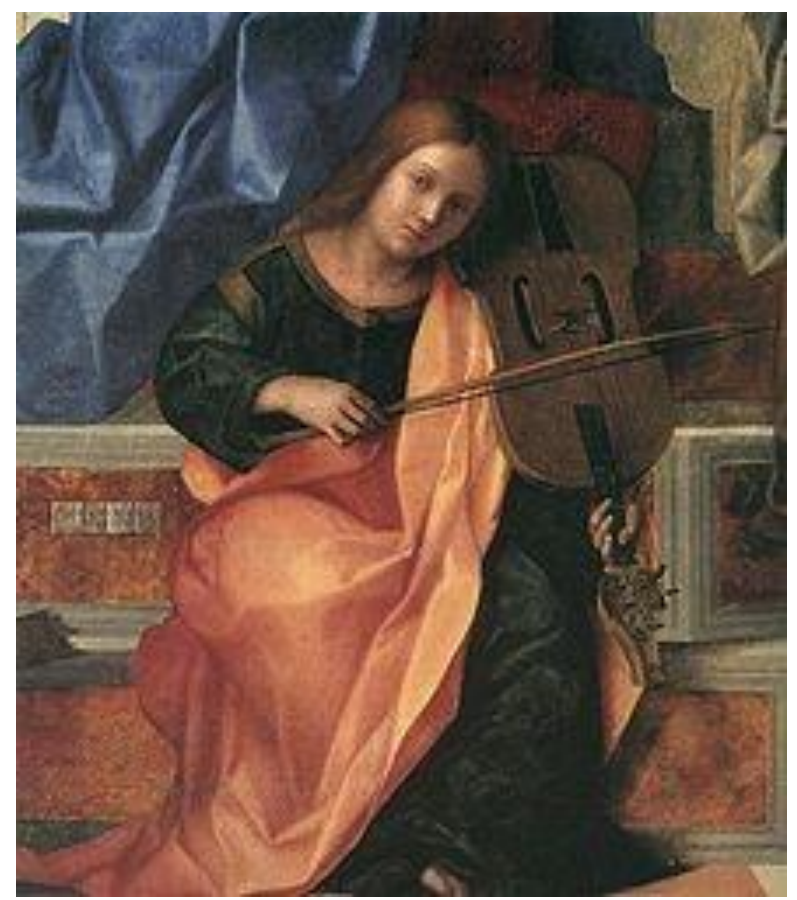

Figura 4 -- Detalhe do altar de San Zaccaria, por Giovanni Bellini ${ }^{14}, 1505$ Fonte: Monteverti (1967, p. 241)

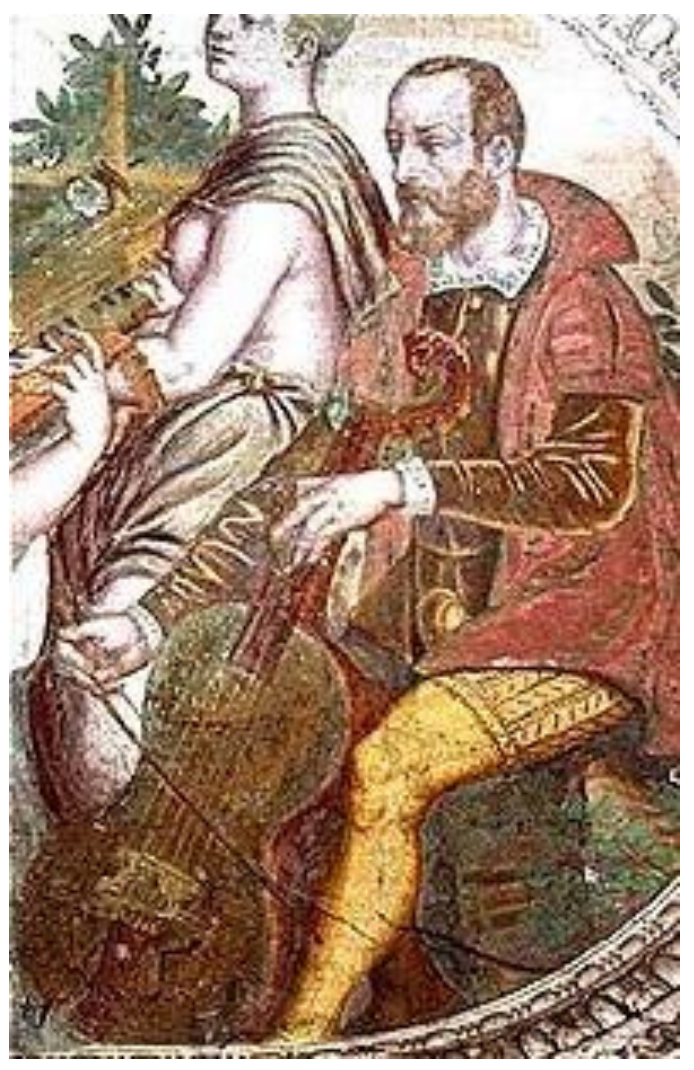

Figura 5 - Afresco italiano retratando um músico tocando viola da gamba, por Lattanzio Gambara, $1560^{15}$

Fonte: Monteverdi (1967, p. 286)

${ }_{14}$ MONTEVERDI, Mario. The Book of Art - Italian Art to 1850. Milan, Grolier, 1967, p. 241.

15 MONTEVERDI, Mario. The Book of Art - Italian Art to 1850. Milan, Grolier, 1967, p. 286. 
$\mathrm{Na}$ evolução do cérebro, o hemisfério esquerdo passa a assumir um papel determinante na organização da fala e dos processos cognitivos ligados à linguagem, como a percepção organizada em esquemas lógicos, a memória verbal, o pensamento lógico e a categorização. O hemisfério direito, por sua vez, assume o papel preponderante no pensamento espacial, na orientação visual e na memória não verbal.

O cérebro trabalha de formas diferentes durante o processo de aquisição da aprendizagem. $O$ hemisfério direito (visual-espacial) atua geralmente em primeiro lugar, captando a informação como um todo para transferir progressivamente a informação para o hemisfério esquerdo (verbal-linguístico) processar.

A lateralidade inata é determinada por fatores genéticos, e é importante que se preserve sua dominância natural sem forçar a troca pelo lado não dominante, para não sobrecarregar os trâmites sinápticos entre as células nervosas nos hemisférios cerebrais, uma vez que o lado dominante apresenta naturalmente um caminho de transferências de informações mais eficiente e de maior precisão de resultados do que $o$ outro lado.

Alguns procedimentos simples podem ajudar a determinar a preferência lateral da visão, da audição e das áreas manual e pedal na criança. Descobrir sua dominância lateral é um importante passo para ajudar a criança a exercê-la. Segundo Fonseca, a apresentação dos objetos oferecidos nesses testes deve ser sempre feita a partir da linha média do corpo da criança para não condicionar o uso pelo lado que foi oferecido pelo professor. A seguir, os procedimentos usados (FONSECA, 1995, p.173-174):

- Lateralização visual. Para avaliar qual é o olho preferencial, pede-se à criança para olhar primeiro através de um tubo ou canudo de papel e depois através de um buraco feito no centro de uma folha de papel.

- Lateralização auditiva: para avaliar o ouvido preferencial, pede-se à criança para escutar um relógio de pulso com ponteiros, e depois simular uma conversa ao telefone.

- Lateralização manual: para avaliar a mão preferencial, pede-se à criança que simule desenhar ou escrever e depois simule cortar um papel com uma tesoura. 
- Lateralização pedal: para avaliar o pé preferencial, pede-se à criança que simule um chute de bola e depois simule vestir uma calça.

O primeiro lado que a criança utilizar para ver, ouvir, segurar algo com a mão ou levantar o pé será o lado preferencial dominante. O outro lado será o lado que exerce a função de apoio ou fundo.

A dominância lateral pode se apresentar nas crianças com três orientações:

- Primária ou homolateral: a dominância se apresenta de um só lado do corpo ou todos os órgãos avaliados são dominantes, ou pela direita, ou pela esquerda;

- Secundária ou dupla contralateral: a dominância se apresenta cruzada metade dos órgãos avaliados são dominantes da direita e metade são dominantes pela esquerda.

- Terciária ou reversível: são casos de ambidestria que apresentam um quadro de perturbações com a tonicidade e a realização das tarefas, por conta de uma lateralidade contrariada ou mal-integrada. Esses casos geralmente necessitam de avaliação psicomotora para definir a lateralização inata da criança.

O processo da dominância lateral se completa por volta dos 4 a 5 anos de idade, e a lateralização manual se estabelece nessa idade independentemente das crianças terem passado por períodos de experimentação ambidestra ou de preferência por outro lado que não o dominante.

O professor de ensino coletivo deve respeitar o tempo de maturação da lateralidade na criança e procurar não antecipar a definição de sua dominância lateral. Antes dos 5 anos de idade convém não insistir no aprendizado sobre as noções de direita e esquerda.

É fundamental que o professor preserve a tendência natural da criança, sem forçá-la a um uso contrário à sua dominâcia, para não provocar um perfil psicomotor desviante e disfuncional que pode comprometer seu desenvolvimento psicomotor e seu potencial cognitivo. Sugerimos uma conduta do professor em relação aos alunos dominantes de mão esquerda e de ouvido direito no capítulo 3.1 Postura corporal global. 


\subsubsection{Noção do corpo}

É a capacidade de nomear, discriminar e apontar as partes do corpo. Para se executar as tarefas diárias, bem como desempenhar habilidades complexas, é necessário que se tenha a consciência do corpo, de suas várias partes e de suas dimensões. O desenvolvimento dessa capacidade de identificação das várias partes do corpo aumenta conforme a quantidade de estímulo que a criança recebe dos pais ou de outros adultos cuidadores.

A noção do corpo está relacionada com a noção de tamanho e peso, com a informação do meio ambiente, dos objetos e dos outros indivíduos, com a informação da gravidade e dos movimentos. A noção do corpo possibilita ao cérebro conhecer as condições em que a atividade motora programada irá se desenvolver.

O corpo é o lugar onde reunimos o conjunto de nossas próprias vivências, que se fundem na autoconsciência e que são resultantes de nossa vida social. Dalila Costallat explica o conceito de esquema corporal citando Ajuriaguerra:

El cuerpo y sus capacidades se construyen antes del nacimiento,
pero la noción de su existencia no nace com él' dijo Ajuriaguerra, su
descubrimiento y toma de conciencia son las resultantes de un
proceso evolutivo posterior que se entrelaza con el desarollo vital del
niño. (COSTALLAT, 1984, p. 26)

Em tradução livre, Ajuriaguerra afirma que "o corpo e suas capacidades se constroem antes do nascimento, mas a noção de sua existência não nasce com ele". Costallat segue afirmando que a descoberta da noção de corpo e a sua conscientização são resultantes de um processo evolutivo posterior que está intrinsecamente ligado ao desenvolvimento da criança. Vítor da Fonseca afirma que:

Com base nestes dados, o corpo transforma-se num instrumento do pensamento e da comunicação. É nele e com ele que nos reconhecemos no que somos. O corpo é em síntese um objeto psicológico... a noção do corpo como noção construída pela própria criança adquire um sentido e uma significação cuja integração está na base das funções psíquicas superiores. (FONSECA, V. 1995, p. 182).

O esquema e a imagem corporais representam a forma como o corpo aparece para nós mesmos, ou seja, a nossa autoimagem corporal, e o seu desenvolvimento ocorre paralelamente ao do nosso aparelho sensório motor. 
No período que vai dos 3 aos 5 anos, a criança desenvolve uma imagem do próprio corpo por imitação e ainda não tem a noção do corpo por inteiro. Somente por volta dos 6 anos, ela consegue totalizar todas as partes do seu corpo, e identificar suas principais partes. Aos 10 anos, sua percepção corporal e de lateralidade se equipara a de um adulto.

O professor de ensino coletivo pode ajudar o aluno a desenvolver sua noção de corpo ao realizar exercícios rítmicos musicais que envolvem a movimentação do corpo por inteiro, como exercícios de marcha com as crianças carregando as caixas de violino nos braços e acima das cabeças, e os "case walk", propostos pela metodologia de Paul Rolland ${ }^{16}$.

A etapa seguinte deve ser exercícios de movimentação com partes do corpo, que podem ser somente as pernas ou somente os braços. Depois podem ser realizados exercícios com partes do corpo cada vez menores e mais específicas, como por exemplo, braços e ombros, mãos e pulsos, dedos e falanges. Dessa forma, o aluno vai experimentando todas as partes do corpo envolvidas no ato de tocar violino, sempre no sentido de sua formação cortical cerebral, das partes maiores para as menores, e no sentido do centro do corpo para as extremidades.

\subsubsection{Estruturação Espaço-Temporal}

Relaciona-se ao nosso sentido de orientação, organização e estruturação do espaço e do senso rítmico do tempo. Esse fator psicomotor é responsável pelo desenvolvimento da atenção seletiva, do processamento da informação, e da nossa coordenação espacial, além de desenvolver a proficiência da linguagem.

Vítor da Fonseca (1995, p.204) cita a afirmação de Piaget sobre a separação dos dois conceitos de estruturação:

Abordar a estruturação espacial separadamente da estruturação temporal é encarar o conceito de espaço antes do conceito de tempo, o que, segundo Piaget (1964), corresponde à gênese da inteligência da criança.

\footnotetext{
${ }^{16}$ ROLLAND, Paul; MUTSCHLER, M. The Teaching of Action in String Playing. Chicago, Illinois: University Press, 1974, p. 69.
} 
Sobre a estruturação espacial, o autor afirma que:

A criança localiza-se a si própria antes de se localizar no espaço ou de localizar objetos no espaço. Localiza os objetos em relação a si própria e, posteriormente, localiza cada objeto sem precisar referi-los corporalmente. Dá-se, consequentemente, uma projeção da lateralização e da noção do corpo no espaço, isto é, a lateralidade desenvolvida no interior do organismo projeta-se no exterior e transforma-se em direcionalidade. (FONSECA, 1995, p. 203)

O senso de direcionalidade é a capacidade de projetar as dimensões espaciais do corpo no espaço e de se apropriar dos conceitos espaciais sobre o movimento e localizar os objetos no ambiente. A percepção da direcionalidade é feita a partir das informações visuais e cinestésicas. Haywood e Getchell (2004, p. 204) afirmam que:

... as crianças melhoram seus sentidos de direcionalidade entre os 6 e os 12 anos. Pelos 8 anos, as crianças podem tipicamente utilizar referências do corpo para indicar direção. São capazes de dizer corretamente 'A bola está a minha direita' e 'A bola está à direita do bastão'. Aos 9 anos, as crianças podem mudar a última sentença para 'A bola está à esquerda do bastão' enquanto caminham em direção oposta aos objetos. Elas podem identificar esquerda e direita em uma pessoa a sua frente. Melhorias como essas nas referências direcionais continuam por volta dos 12 anos.

Toda informação relacionada ao espaço deve ser interpretada pelo corpo. Pela noção do corpo podemos calcular a quantidade de movimento necessário para explorar o espaço, ou para poder pegar algum objeto situado no espaço. Pela quantidade de movimento medimos a distância percorrida no espaço para alcançar o objeto. É através da movimentação do nosso corpo que adquirimos conhecimento da distância espacial, ou seja, transformamos o conhecimento do corpo em conhecimento do espaço.

A estruturação temporal é mais elaborada que a estruturação espacial uma vez que transcende a experiência sensorial imediata, pois a noção do tempo é abstrata e artificial. E mais uma vez, Vítor da Fonseca (1995, p.209) afirma que:

Através da estruturação temporal, a criança tem consciência da sua ação, o seu passado é conhecido e atualizado, o presente é experimentado e o futuro desconhecido é antecipado. Essa estrutura de organização é determinante para todos os processos da aprendizagem. A noção do tempo é uma noção de controle e de organização, quer ao nível da atividade, quer ao nível da cognitividade. 
A dimensão do tempo além de fornecer a localização dos acontecimentos de forma cronológica, também preserva as relações entre esses acontecimentos. Por meio dessas relações é que chegamos aos conceitos de simultaneidade, sincronização e sequência, tão importantes para o processo de aprendizado musical.

A unidade que mede essa extensão temporal é o ritmo, que envolve a consciência da igualdade dos intervalos de tempo. Um ritmo constante forma uma cadência ou uma série de intervalos iguais, fenômeno que observamos em muitos ciclos biológicos e físicos (como por exemplo, a circulação, a respiração, as fases da Lua, a rotação da Terra).

O ritmo é uma propriedade fundamental do ser vivo e caracterizado por baixas, médias e altas frequências. Ocorre em várias áreas do comportamento humano: na motricidade (coordenação de movimentos), na audição (reconhecimento do som), na visão (na exploração organizada do meio ambiente) e nos aprendizados escolares e musicais. Por isso, a estruturação temporal é de enorme importância nas funções da percepção sensorial, da associação, da programação e da expressão de conteúdos, principalmente no que se refere aos estudos musicais.

O professor de ensino coletivo pode ajudar a desenvolver a estruturação espaço temporal de seus alunos por meio de exercícios que explorem o espaço como os sugeridos no item anterior 2.3.4 Noção do Corpo. Exercícios de marcha e caminhada em passos ritmados pelo espaço da sala de aula ajudam o aluno a compreender o espaço e suas distâncias, e a administrar sua movimentação corporal em relação a esse espaço. Esse é o princípio para se desenvolver a pulsação rítmica interna dos alunos.

O ritmo, em um exercício musical, deve ser compreendido primeiro pelo corpo, por meio de sua movimentação no espaço, para depois ser entendido pela mente, por meio do conhecimento da escrita musical e suas subdivisões. Todo exercício musical deve ser solfejado e cantado acompanhado de palmas, batidas de pé e passadas em ritmo antes de ser tocado pelas crianças no violino. Assim, exige-se a movimentação do corpo todo, e é dessa maneira que o cérebro inicia o processo de sua apropriação dos elementos novos, sempre do geral para o específico, para depois aprender a movimentar as partes menores do corpo envolvidas na aprendizagem, como os braços e mãos. 


\title{
2.3.6 Praxia Global
}

As habilidades motoras podem ser classificadas de acordo com a precisão do movimento envolvido: habilidades motoras globais e habilidades motoras finas.

As habilidades motoras globais são caracterizadas por envolver a grande musculatura do corpo como base principal do movimento, como as habilidades motoras fundamentais de andar, saltar e arremessar. Richard Magill esclarece que nesse tipo de habilidade global:

Embora a precisão do movimento não seja um componente importante (no estudo da praxia global ${ }^{17}$ ), a coordenação perfeita do movimento é essencial ao desenvolvimento hábil dessas tarefas. (MAGILL, 1984, p. 15)

Segundo Le Boulch (1983), a praxia pode ser definida como um sistema de movimentos coordenados em função de um objetivo a ser atingido. Para ser desencadeada a praxia global necessita que outros fatores psicomotores estejam funcionando em boas condições, como a lateralização, a noção do corpo e a estruturação espaço-temporal. Assim, ela pode realizar sua função de integrar a postura, a locomoção, o contato e a percepção dos objetos.

Também para que a praxia global se desenvolva, é necessário ocorrer a maturação das coordenações visual, manual e pedal, junto com a maturação do sistema motor. Todas as praxias exigem uma autoconsciência corporal, que é formada pelos movimentos do próprio corpo. Vítor da Fonseca (1995, p. 226) afirma que:

\begin{abstract}
A praxia global encerra em si a unidade de um pensamento abstrato que se traduz numa ação motora concreta... o movimento voluntário é definido em relação à sua finalidade, que só pode ser desencadeada internamente, quando os sistemas vestíbulo e visuoespacial conferem as necessárias condições de estabilidade postural, porque só assim o cérebro pode concentrar-se no fim a atingir.
\end{abstract}

Por meio da observação da qualidade de execução de um ato motor, e das formas de sua realização, podemos captar sinais sobre a organização psicomotora da criança e sua repercussão no seu desenvolvimento motor afetivo e intelectual.

\footnotetext{
${ }^{17} \mathrm{O}$ esclarecimento entre parênteses é nosso.
} 


\subsubsection{Praxia Fina}

A praxia fina é responsável pela concentração, pela organização e pela especialização hemisférica. A coordenação adequada das praxias global e fina gera harmonia corporal e é uma conquista evolutiva do ser humano.

As habilidades motoras finas requerem a capacidade de controlar os músculos pequenos do corpo, a fim de executar com precisão seu objetivo, como escrever, desenhar, tocar violino e outros movimentos finos. Sobre as habilidades finas, Magill (1984, p. 15) afirma:

Geralmente, essas habilidades envolvem coordenação óculo-manual e requerem um alto grau de precisão no movimento para 0 desempenho da habilidade específica, em um nível elevado de realização.

O enfoque central da praxia fina é a mão humana, que é a unidade motora mais complexa do mundo animal, e responsável em grande parte pela construção da civilização humana, por meio da fabricação de ferramentas e utensílios. A mão é também o órgão que explora o mundo exterior, reconhecendo os objetos pela textura, peso, forma e temperatura. Em cooperação com a visão, a mão realiza importantes funções de preensão, como segurar, riscar, catar, lançar, puxar, empurrar, entre outros.

A praxia fina está relacionada com a capacidade de construção manual na criança e com a sua destralidade manual em todos os processos de aprendizagem. A precisa coordenação das duas mãos é essencial para o desenvolvimento do aprendizado na criança. Vítor da Fonseca (1995, p. 247) afirma que:

Mão e inteligência ligam-se e formam-se dialeticamente. Nem a mão, nem a inteligência isoladas em si próprias podiam construir os programas de ação que permitiram a capacidade de fabricar instrumentos, razão fundamental do fenômeno humano.

É a partir da praxia fina que toda a construção intelectual da história da humanidade tomou forma, por meio das artes, literatura, manufatura e outras construções do processo da civilização.

A praxia fina do músico, do cirurgião ou do escritor, por exemplo, é resultado da combinação de conhecimento, planejamento e imaginação, cuja manifestação 
integrada se apresenta por meio dos seus movimentos, que são ao mesmo tempo criadores e conscientes. Como produto final da integração de todos os demais fatores psicomotores, ela só se apresenta adequadamente na criança, quando ocorre uma adequada maturação neurológica.

O professor de ensino coletivo pode observar e desenvolver as praxias global e fina de seus alunos por meio de: exercícios de equilíbrio e coordenação corporal, conceitos de transferência de peso entre os membros superiores no uso do arco e de preensão dos dedos na mão esquerda sobre as cordas.

Exercícios de independência dos dedos das duas mãos são muito importantes para desenvolver a praxia fina, assim como a correta coordenação entre o aspecto visual da leitura da partitura e coordenação entre as duas mãos, no arco e no violino respectivamente. 


\section{EXERCÍCIOS PREPARATÓRIOS PARA O APRENDIZADO NO VIOLINO BASEADOS EM PRINCÍPIOS PSICOMOTORES}

Todos os movimentos do nosso corpo obedecem às leis naturais da Física, especificamente da dinâmica, que é a área da física mecânica que estuda as causas do movimento. É por isso que, para compreendermos as causas e os fatores que influenciam os nossos movimentos ao tocar o violino, é necessário entendermos estas leis, e conhecer os conceitos de força e equilíbrio.

As forças que ocorrem na natureza se apresentam de duas formas: podem ser de contato, que ocorre quando uma pessoa está puxando o arco sobre a corda do violino, por exemplo; ou de ação à distância, quando as superfícies não se encostam, como a ação da gravidade ou de um campo magnético sobre os corpos. O equilíbrio pode ser classificado em estático, quando os corpos estão em repouso, ou dinâmico, quando os corpos estão em movimento retilíneo uniforme.

O equilíbrio ocorre em toda a situação em que as forças atuantes em determinado corpo se cancelam. ${ }^{18}$

Além disso, temos também a força do atrito, que pode ser estático, quando o corpo está em repouso, ou dinâmico, também conhecido como cinético, quando os corpos estão em movimento.

Na dinâmica, o estudo de todos os movimentos pode ser resumido em três leis sintetizadas pelo físico Issac Newton, que descrevemos a seguir.

\section{Primeira lei}

É também conhecida como o Princípio da Inércia. Ela descreve o que ocorre com os corpos em equilíbrio. Seu enunciado é:

\footnotetext{
"Um corpo tende a manter seu estado de repouso ou de movimento retilíneo uniforme se a resultante das forças que agem sobre ele for nula. (SARKIS; PIRES; GUADALUPE, 2011, p. 71)
}

Isso significa que todos os corpos na natureza, apresentam resistência a alterações no seu estado de equilíbrio. Então, se um objeto se encontra em repouso,

18 Disponível em: <<http://educacao.uol.com.br/fisica/dinamica-as-leis-de-newton.jhtm/pg.1 1>>. Acesso em: 05 julho 2012. 
ele tenderá a permanecer neste estado a não ser que uma força externa desequilibre este equilíbrio estático, acontecendo o mesmo para um corpo em equilíbrio dinâmico.

Ao posicionarmos o arco no violino, estaremos lidando com os dois tipos de equilíbrio, que ocorre entre o braço e o ponto de contato do arco na corda, assim como com os dois tipos de atrito entre a crina e as cordas. Antes de dar a partida a qualquer movimento, nosso braço deve vencer o atrito estático e a inércia do arco sobre a corda. Esse atrito estático é sempre maior do que o atrito dinâmico para objetos compostos do mesmo material; é, em geral, maior nos casos em que o corpo não altera sua quantidade de massa $(\mathrm{kg})$, como confirmam os estudos em Física:

... os números $\mu_{\text {est. }}$ e $\mu_{\text {din. }}$ são denominados respectivamente, coeficientes de atrito estático e dinâmico. Os coeficientes de atrito estático e dinâmico dependem da natureza das superfícies em contato (material e acabamento); para cada par de materiais em contato, o coeficiente de atrito estático é maior que o coeficiente de atrito dinâmico: $\mu_{\text {est. }}>\mu_{\text {din. }}$. (GARCIA, 2001, p. 2-3)

O coeficiente de atrito estático é sempre superior ao do coeficiente de atrito cinético para os mesmos materiais das mesmas superfícies em contacto. Na tabela seguinte apresentam-se alguns valores para coeficientes de atrito. (SÁ, 2001, p. 48-53)

Tabela 2 - Coeficiente de atrito estático X cinético

\begin{tabular}{lll}
\hline Materiais & $\mu_{\mathrm{e}}$ (atrito estático) & $\mu^{\mathrm{c}}$ (atrito cinético) \\
madeira/madeira & 0,4 & 0,2 \\
gelo/gelo & 0,1 & 0,03 \\
metal/metal (com lubrificação) & 0,15 & 0,07 \\
\hline
\end{tabular}

Fonte: Sá (2001)

Portanto, uma vez constatada a diferença entre os atritos estático e dinâmico, concluímos que para iniciar qualquer movimento estando nosso corpo em repouso, gastaremos mais força do que se o conjunto composto pelo nosso braço, o arco e o violino já se encontrasse em movimentação.

Baseado nesse princípio, toda vez que o aluno vai iniciar qualquer movimento com o arco e o violino, deve sempre antecipar o seu movimento com uma respiração ou, mais especificamente, com uma inspiração. Esse ato de inspirar o ar causa uma moderada movimentação corporal, suficiente para diminuir o atrito estático e, consequentemente, exigir menos esforço dos ombros, braços e mãos para executar 
a arcada. O resultado final são músculos e tendões mais relaxados e frases musicais mais bem executadas, com fluidez e organicidade.

\section{Segunda lei}

Também conhecida como o Princípio Fundamental da Dinâmica. Ela descreve o que ocorre com os corpos que não estão em equilíbrio. Quando diversas forças atuam sobre um corpo, e elas não se anulam, a força resultante imprimirá ao corpo uma aceleração. Para corpos que mantêm a mesma massa (medida em quilogramas), essa lei é enunciada pela fórmula: $\boldsymbol{F r}=\boldsymbol{m} \cdot \boldsymbol{\alpha}$

A saber, $\boldsymbol{F r}$ é a força resultante que tem a mesma direção da aceleração $\boldsymbol{\alpha}, \mathrm{e}$ $\boldsymbol{m}$ representa a massa do corpo.

$F r=m . \alpha$ é um enunciado simplificado da Segunda Lei de Newton, sendo válido para o caso da massa constante... observamos que, aplicando a mesma força para corpos de massas diferentes, as acelerações serão diferentes... Portanto, quanto maior a massa, menor a mudança na velocidade provocada pela força (SARKIS, PIRES; GUADALUPE, 2011, p. 72).

A aceleração do nosso braço tocando com o arco na corda está relacionada com o peso que transferimos para a corda por meio do braço e também com o atrito gerado entre a crina e a corda. De acordo com a segunda lei de Newton, quanto maior a aceleração que desejamos obter do arco, menos pressão devemos fazer sobre o arco para diminuir o peso que transferimos do braço sobre a corda e assim diminuir o atrito.

\section{Terceira lei}

Também conhecida como o Princípio de Ação e Reação. Ela descreve o comportamento das forças quando temos dois corpos interagindo entre si.

Se um corpo A exerce uma força sobre outro corpo B, então o corpo $B$ exerce sobre o corpo A uma força de mesmo módulo e mesma direção, mas de sentido contrário: $F \boldsymbol{a}=$ - $\boldsymbol{F b}$. (SARKIS, PIRES; GUADALUPE, 2011, p. 73)

Em outras palavras, a terceira lei diz que se um corpo exerce uma força em outro corpo, imediatamente receberá desse outro uma força de igual intensidade, na mesma direção, mas em sentido oposto à força que aplicou. 
Se para cada ação que uma pessoa realiza resulta em uma reação de mesma intensidade e com direção oposta, então qualquer força que for aplicada fora do plano do movimento resultará em reações indesejadas e perda de eficiência na performance. Se desejamos puxar o arco do talão até a ponta, por exemplo, então qualquer força exercida em outras direções fará como que a ação de tocar seja menos eficiente, pois subtrairá da força original a capacidade de se concentrar naquele movimento planejado.

Podemos ver a lei da ação e reação sendo aplicada entre algumas partes do corpo. Haywood e Getchell (2004, p. 110) afirmam que:

\begin{abstract}
Em habilidades locomotoras como a corrida, os membros inferiores giram para um lado, e os superiores, para o lado oposto. Uma das pernas se impulsiona para a frente, e o braço naquele lado do corpo se impulsiona para trás em reação. A perna em um dos lados do corpo e o braço no oposto se impulsionam para a frente e para trás em uníssono.
\end{abstract}

Para obter o máximo de eficiência no impulso e no movimento, é necessário movimentar o par de membros opostos (superior e inferior) na mesma direção. No ato de tocar violino, podemos constatar que para obter maior equilíbrio corporal ao iniciar uma arcada que exija força e ataque de nota precisos, o aluno deve posicionar o braço direito no talão em combinação com o pé esquerdo ligeiramente na frente em comparação com o outro pé. Essa oposição entre o braço e a perna opostos proporciona maior estabilidade e eficiência no uso da força.

\title{
3.1 POSTURA CORPORAL GLOBAL
}

Os movimentos que executamos com nosso corpo são compostos, na sua grande maioria, por movimentos rotatórios por meio das juntas e articulações. Ao iniciarem uma ação no violino, por exemplo, nossos membros enfrentam uma resistência provocada pela inércia e que está relacionada com a quantidade de massa do corpo em movimento.

Conforme o comprimento do braço aumenta, também aumenta a resistência ao movimento devido ao atrito, assim como a quantidade de energia requerida para 
mover o arco no violino. Porém, ao flexionarmos o membro que vai se mover diminuímos a energia necessária para movê-lo, uma vez que o braço passa a funcionar como um sistema de alavancas.

Os movimentos que executamos ao violino envolvem não apenas os braços e mãos, mas também aquelas partes do corpo que se movem em sequência, cuja movimentação é conhecida como cadeia cinética aberta. Haywood e Getchell (2004, p. 112) explicam essa cadeia cinética por meio do exemplo de crianças aprendendo a arremessar um objeto:

Há dois elementos essenciais para a cadeia cinética aberta. Primeiro, existe uma sequência de movimentos ótima. Igualmente importante é a sincronia dos eventos dentro dessa sequência... Na realidade, os aprendizes utilizam amiúde ações ou movimentos separados ao executar habilidades motoras. Conforme eles continuam a executar essas habilidades, começam a unir e a sincronizar esses movimentos desconexos; como resultado, passam a mover-se com mais proficiência.

Para conseguir coordenar as ações separadas e sincronizar os movimentos dentro da cadeia cinética, as crianças necessitam apresentar um amadurecimento dos fatores psicomotores em seu desenvolvimento. A primeira tarefa do professor de ensino coletivo é fazer uma verificação do nível de desenvolvimento motor em que se encontram seus alunos, para só então planejar suas aulas de acordo com a situação.

Para ajudar os alunos a desenvolver suas aptidões motoras em relação ao violino, é necessário realizar os exercícios preparatórios antes de estudar os exercícios do Método para Ensino Coletivo de Violino, situado no capítulo 5. Dessa forma, estaremos preparando sua postura ao instrumento, evitando criar tensões musculares desnecessárias.

Esses exercícios são sempre realizados com repetições, e o número das repetições é sempre múltiplo de quatro. A razão disso é criar no aluno um senso de forma musical, uma vez que a pulsação quaternária simples é uma das formas rítmicas mais fáceis de assimilar no início do aprendizado do instrumento. Outra razão para adotar esse número de repetições é que ele ajuda na finalização das arcadas: o aluno inicia o estudo posicionando o arco em determinada região e, por ser um número par, termina o exercício com o arco posicionado na mesma região, o que facilita o aprendizado na fase inicial. 
Os fatores psicomotores a serem verificados com os alunos podem ser agrupados segundo sua finalidade.

\section{Tonicidade e Equilibração}

O primeiro fator a ser verificado é a tonicidade do aluno. Devemos verificar a tendência natural do aluno, isto é, se apresenta uma tonicidade corporal adequada para a tarefa ou se é hipertônico ou hipotônico.

Em uma classe coletiva, podemos detectar esse fator por meio de exercícios simples, como realizar um desenho livre em um papel branco. O simples traço do lápis e a própria força empregada para segurá-lo são indicativos da tonicidade natural da criança. É importante utilizar elementos familiares às crianças para realizar esse teste, e não usar o arco e violino para esse fim, pois ainda se tratam de objetos estranhos a elas, e a tendência natural é tensionar mais do que o normal ao tentar manipular os instrumentos desconhecidos.

Uma vez feito um quadro da tonicidade em classe, devemos realizar exercícios com base na média das tonicidades apresentadas e dedicar atenção especial aos casos mais extremos de hipertonicidade ou hipotonicidade.

É importante ressaltar que, embora a tonicidade seja um fator que se apresenta como uma tendência natural, que não é passível de mudanças, podemos ajudar a criança a desenvolver o uso equilibrado de sua tonicidade por meio de exercícios, que estão descritos mais adiante neste mesmo capítulo.

\section{Lateralização e Noção do corpo}

A tomada de consciência corporal, por parte da criança, de cada parte dos seus membros e dos sentidos de direita e esquerda é essencial para a compreensão sobre a função e plástica dos movimentos que executa ao violino.

Somente por volta dos 11 anos de idade é que a criança desperta para a consciência integral de seu corpo. Por isso, é muito importante ensinar às crianças desde os 6 anos a conhecer e movimentar cada parte do seu corpo envolvido no ato de tocar violino.

A noção do corpo é fundamental para solidificar o aprendizado e criar a compreensão dos próprios atos, pois, uma vez que o aluno se torna consciente de como deve realizar os movimentos corretos, ele mesmo pode se examinar e procurar se corrigir enquanto toca violino. Essa autocorreção é muito mais eficiente na 
prevenção de lesões musculares e inflamações de tendões do que a simples imitação do professor na execução dos movimentos.

Para criar a consciência corporal, devemos ensinar a criança a movimentar todo o corpo e depois cada parte dele, conforme os exercícios anteriormente citados no capítulo 2.3.4 Noção do Corpo, buscando a integração de todas as partes do corpo e depois buscando a independência nos movimentos de cada parte.

É consenso entre todos os autores de estudos e pesquisas sobre psicomotricidade e desenvolvimento motor citados até agora que se deve respeitar a dominância lateral natural de um indivíduo, cuja contrariedade resulta em sobrecarga para os circuitos cerebrais.

Isso ocorre porque, para efetuar uma ação que exige foco, concentração, força, destreza e precisão, ou seja, aquilo que deveria ser executado pelo órgão ou membro dominante e que passa a ser efetuado pelos circuitos neuronais de apoio, os hemisférios cerebrais transferem a informação de um lado para o outro, despendendo um gasto energético muito maior. Além disso, para conseguir efetuar a ação a contento, ele deixa de executar algumas funções que eram rotina para atender à nova demanda. Portanto, é necessário que o professor procure preservar a dominância natural do aluno.

Os testes sugeridos no capítulo 2.3.3 Lateralização podem ajudar a mapear a dominância lateral dos alunos, sendo que, dentre todos os tipos de dominância, os que de fato concernem ao estudo do violino são a dominância manual e a auditiva.

A dominância manual esquerda no aluno suscita uma série de questões, como se o fato de o aluno ser canhoto implicaria em mudar o posicionamento do violino para o ombro direito com inversão do cavalete e das cordas e, consequentemente, a mão do arco seria a esquerda. Sobre esse assunto, não há uma diretiva conclusiva, uma vez que ambas as mãos exercem funções distintas de alta especificidade técnica. E como já foi tratado anteriormente no capítulo 2.3.3 Lateralização, as razões de o arco ser historicamente colocado na mão direita podem ser assumidas por suposição apenas, não tendo uma relação necessária com a dominância manual destra.

Da mesma forma, a dominância auditiva direita suscita o questionamento de, se pelo fato do violino ser colocado no ombro esquerdo, estaria contrariando a dominância de ouvido direito de uma pessoa. 
Nesse caso, porém, podemos afirmar que por causa da proximidade do violino do ouvido esquerdo, forçosamente esse será mais exigido na escuta, uma vez que a lateral do violino encosta no pescoço, a cerca de $5 \mathrm{~cm}$ do ouvido esquerdo, e o som produzido ecoa muito mais alto nesse ouvido do que no outro.

Como não é nosso objetivo nos aprofundar em uma pesquisa científica sobre as perdas neurológicas por uso excessivo do ouvido de apoio, podemos apenas sugerir uma conduta ao professor de ensino coletivo. Antes de inscrever os alunos na aula de violino, sugerimos que seja feito um exame de dominância auditiva com os pretendentes à aula de instrumento por meio dos dois testes simples já descritos anteriormente, a saber: fingir atender um telefonema e escutar o tic-tac de um relógio de ponteiros. Convém lembrar que os objetos devem ser sempre apresentados ao aluno na linha média de seu corpo para não influenciá-lo pelo lado que vai realizar a escuta.

Uma vez feito o teste, se forem constatados casos de dominância auditiva direita, a sugestão é encaminhar os alunos para estudar instrumentos cuja produção sonora seja mais central, como o violoncelo, o contrabaixo, o piano e outros.

\section{Estruturação espaço-temporal}

Para desenvolver a estruturação espaço-temporal com os alunos, é necessário realizar a exploração do espaço da sala de aula por meio de exercícios rítmicos, como caminhadas, marchas, palmas e batidas de pés.

Sugerimos que sejam escolhidas algumas músicas ritmadas de conhecimento geral, como, por exemplo, a canção infantil Marcha soldado. A seguir, a melodia é ensinada para as crianças, que aprendem a cantar ao mesmo tempo em que batem os pés na pulsação da música. O próximo passo é realizar as marchas com as caixas de instrumentos, de modo já citado acima no item Tonicidade e Equilibração.

Durante a marcha, o professor pode tocar a música, acelerando o ritmo ou retardando-o em alguns momentos, para que as crianças pratiquem a marcha com andamentos diferentes. Da mesma forma, as crianças podem alternar passos largos com passos curtos e programar paradas ou pausas na marcha.

Todas essas atividades ajudam a internalizar o ritmo musical por meio da vivência do espaço. 


\section{Praxias global e fina}

A correta preensão e manipulação dos objetos, como o violino e o arco, devem ser desenvolvidas por meio de exercícios de preensão palmar e preensão digital. Os movimentos maiores e mais amplos sempre devem ser executados antes, para só depois afinar seus detalhes e especificidades. Descrevemos adiante uma série de exercícios para desenvolver essas duas praxias.

Os exercícios preparatórios listados neste capítulo foram elaborados utilizando os fatores psicomotores como parâmetro. Os alunos aprendem desde a postura de como ficar de pé, a colocação correta do violino e do arco, até como preparar a musculatura para questões técnicas básicas. Essa rotina de posturas corporais e exercícios deve ser ensinada durante todo o período de aulas do primeiro mês das turmas iniciantes. Depois do primeiro mês, devem ser selecionados alguns exercícios a serem aplicados durante os primeiros 15 minutos das aulas coletivas.

Lembramos que a sequência dos exercícios deve ser respeitada quando for ensinado pela primeira vez, e que todo conceito novo a ser apresentado para as crianças de faixa etária dos 6 aos 12 anos deve ser primeiramente explicado de maneira breve e objetiva, a partir de exemplos concretos que fazem parte do repertório cotidiano delas. Por meio de repetições do exercício, a compreensão do conceito se solidifica na memória dos alunos por conta da familiaridade com os exemplos.

\section{Manutenção do equilíbrio corporal}

Uma tonicidade adequada está intimamente ligada a um bom equilíbrio corporal. Ao ficar de pé, devemos estabelecer uma postura livre de tensões estáticas. Por isso, precisamos nos certificar se os alunos estão com as juntas do corpo soltas, sem travar nenhuma parte delas, desde o tornozelo, joelhos, quadris, lombar, cervical, ombros, cotovelos, pulso e dedos.

Uma posição balanceada dos pés é a base de toda a sustentação do corpo. Ao ficar de pé, a criança deve manter os pés alinhados, cada qual com um dos lados do quadril, e com o pé esquerdo posicionado ligeiramente à frente em relação ao direito. Essa posição permite um apoio maior para o impulso do braço direito no arco e auxilia na liberação da tensão muscular do lado direito do corpo. Isso acontece porque os reflexos e as respostas de tensão sobre os membros opostos são 
cruzados, ou seja, quando o pé esquerdo está à frente, ele suporta a maior parte do peso do corpo, liberando consequentemente o lado direito para sua tarefa no arco.

No início de aprendizado, de acordo com nossa metodologia, exige-se maior controle motor do lado direito do corpo por causa do uso do arco. Posteriormente, nas etapas mais avançadas da técnica, como o treino de velocidade, vibrato e mudança de posição, a mão esquerda será mais exigida do que a direita. O aluno então aprenderá a se apoiar mais na perna direita do que na esquerda para aliviar a tensão do lado esquerdo do corpo.

Os sentidos da percepção que mais participam da atividade musical são o auditivo, o visual, o tátil e o cinestésico. Todos eles participam da preparação dos músculos que garantem o equilíbrio de nossa postura, criando respostas rápidas e reflexos prontos para a execução do ato musical, de forma que, quando estamos equilibrados, também os nossos órgãos sensoriais descansam, fortalecendo-se dessa forma.

O ouvido é um dos órgãos da percepção mais sobrecarregados pela atividade musical, além de receber uma carga enorme de ruídos do meio ambiente, principalmente para aqueles que vivem nos grandes centros urbanos. Para proteger o ouvido e fortalecê-lo, o pesquisador Géza Kovács ${ }^{19}$, junto com a pianista Zsuzsa Pásztor, desenvolveu uma série de exercícios para promover o equilíbrio corporal. Postulava que, sendo o ouvido o órgão responsável pela audição e pelo equilíbrio, quando exercitamos o equilíbrio corporal, indiretamente descansamos o ouvido:

Esto se debe a su situación anatómica y a que los receptores que registran los estímulos en ambos órganos sensitivos están localizados en el oído interno. El órgano auditivo y el del equilibrio comparten venas y liquido perilinfático. Desde el punto de vista circulatório, los dos receptores forman una única unidad funcional. Los experimentos pedagógicos de la Dra. Klára Kokas han demostrado que los estímulos que contribuyen al desarollo del oído musical también mejoran el equilibrio. La explicación es que al usar el órgano auditivo, el aumento del flujo sanguíneo mejora el metabolismo del sistema de equilibrio adyacente. (KOVÁKS; PÁSZTOR, 2010, p.18).

\footnotetext{
${ }^{19}$ Dr. Géza Kovács (1916-1999) foi membro do Instituto de Investigação Científica de Educação Física de Budapeste. Em 1959, o Conservatório de Budapeste lhe incumbiu da investigação das causas do aumento das lesões entre músicos profissionais e estudantes. Ao longo de vários anos desenvolveu um programa de exercícios destinado às necessidades dos músicos, conhecido como The Care of Musicians' Work Capacity - Kóvacs Method.
} 
Em tradução livre, Kovács afirma que o descanso do ouvido se deve à sua situação anatômica, pois os receptores que registram os estímulos dos dois órgãos sensitivos estão localizados no ouvido interno. O órgão auditivo e o de equilíbrio compartilham veias e líquido linfático; do ponto de vista circulatório, ambos formam uma única unidade funcional. Experiências pedagógicas citadas por Kovács demonstram que os estímulos que contribuem para o desenvolvimento do ouvido musical também melhoram o equilíbrio corporal. A explicação é que ao usar o órgão auditivo, o aumento de fluxo sanguíneo melhora o metabolismo do sistema de equilíbrio adjacente.

Seguindo essa lógica, se desenvolvermos o equilíbrio corporal, por causa dessa conexão íntima e compartilhamento de recursos, a audição será beneficiada também. Portanto, para descansar o ouvido, é indispensável praticar movimentos que promovam o equilíbrio corporal. Criamos cinco exercícios segundo esses princípios da psicomotricidade:

\section{Exercício preparatório 1}

Em pé, ficar apoiado em uma só perna durante 10 segundos. Em seguida, repetir o exercício com os olhos fechados. Realizar o mesmo exercício com a outra perna.

\section{Exercício preparatório 2}

Girar sobre o próprio eixo vertical, três vezes para direita e três para esquerda.

\section{Exercício preparatório 3}

Andar em círculos, saltando com os joelhos levantados para a frente do corpo.

\section{Exercício preparatório 4}

Apoiado na perna direita, elevar a esquerda para trás e esticar o braço direito para adiante do corpo, alinhando o braço direito esticado, o tronco e a perna esquerda esticada para trás. O tronco forma um ângulo de 90 graus em relação à perna apoiada. Permanecer por 10 segundos e trocar de lado. 


\section{Exercício preparatório 5}

Caminhar em linha reta e com os olhos fechados por quatro passos para frente e depois quatro passos para trás. Este exercício deve ser feito com a supervisão de um colega ou do professor.

\section{Tensão x relaxamento muscular:}

Ao abordar relaxamento muscular com crianças da faixa etária inicial de 6 anos, o que acontece na quase totalidade das vezes é de elas incorrerem em imagens errôneas de frouxidão total do tônus ou de um amolecimento de toda a musculatura.

Esse desmoronamento da estrutura de sustentação do corpo não corresponde ao objetivo que buscamos para obter um tônus muscular equilibrado e sem tensões musculares prejudiciais. De nada nos serve um corpo sem tônus ou sem a sustentação muscular mínima, que não consegue sustentar o violino corretamente no ombro, nem permanecer com o braço direito na posição correta.

\section{Exercício preparatório 6}

O primeiro exemplo sobre o tônus muscular a ser demonstrado é pedir aos alunos que fiquem de pé. Eles devem encher os pulmões com ar ao mesmo tempo em que contraem propositadamente os ombros, elevando-os em direção à cabeça e assim permanecer por cinco segundos. Logo em seguida, deve-se pedir que soltem o ar dos pulmões de uma só vez, seguido da soltura dos ombros, que retornarão à posição inicial de repouso.

O incômodo causado pela tensão dos ombros ficará na memória deles como sendo a tensão a ser evitada, e o alívio da soltura dos ombros será memorizada como sendo o relaxamento ideal, cuja sensação deverão buscar por todo o tempo em que estiverem tocando com o violino nos ombros.

\section{Manutenção dos eixos vertical e horizontal do corpo:}

O nosso corpo pode ser dividido em dois eixos: o vertical, por meio de uma linha imaginária que perpassa o centro da nossa cabeça, segue a coluna e vai até o chão; e o horizontal, cujo alinhamento deve ocorrer entre a linha do quadril e a dos ombros. Manter esses dois eixos deve ser um dos principais objetivos do aluno inciante, pois são os eixos de sustentação do corpo que permitem o perfeito 
funcionamento de nosso sistema de amortecimento e movimentação, por meio do uso das juntas e das articulações.

\section{Exercício preparatório 7}

O professor deve buscar dar exemplos com uso de imagens concretas para que o aluno possa compreender facilmente esses dois eixos imaginários. Uma das maneiras é pedir que o aluno fique de pé e observe o alinhamento dos pés em relação ao quadril, e conferir se os seus joelhos se encontram levemente flexionados.

Uma situação muito comum quando se pede à criança que fique de pé com a coluna "reta" é que ela geralmente trava os dois joelhos, empurrando a patela para trás do corpo. Muitas vezes, demonstrar o exagero de uma situação pode ajudar a esclarecer movimentos pequenos ou sutis que seriam difíceis de entender pela criança. O professor pode demonstrar pelo exagero o que acontece nessa situação, pois ao travar os joelhos, a parte superior do tronco é projetada para frente, e a pessoa fica corcunda, com o rosto voltado para o chão. Como ninguém quer ficar olhando para o chão o tempo todo, a criança acaba por ajeitar o tronco, forçando a cabeça para trás. Essa postura forçada é o resultado da falta de liberdade na articulação dos joelhos.

Para ajeitar corretamente a coluna, de maneira que ela esteja em liberdade de movimentação e bem apoiada, devemos soltar os joelhos, deixando-os ligeiramente flexionados. Pede-se à criança que mexa os joelhos para frente e para trás, sem, contudo, tirar a sola dos pés do chão. Deve-se tomar cuidado para não exagerar na flexão dos joelhos e assim não sobrecarregar as pernas com um movimento de agachamento.

Uma maneira prática de exemplificar o eixo vertical é pedir ao aluno que imagine que tem um fio de cabelo no topo da cabeça que está preso ao teto. Pode-se pedir que o aluno puxe de leve o próprio cabelo para ter essa sensação de estar preso ao teto. O aluno não deve permitir que esse fio de cabelo se desgrude do teto ao entortar a cabeça para a direita ou para a esquerda, perdendo esse eixo central. Dessa forma, evita-se que o aluno entorte a cabeça para tentar prender erroneamente o violino no ombro.

O outro eixo que se deve prestar atenção é o horizontal, formado pela linha do quadril em paralelo com a linha dos ombros. A manutenção desse eixo permite ao aluno manter seu equilíbrio corporal sem torções na linha da cintura e dos ombros, 
que chamaremos de posição base. Essa posição deve ser mantida na maior parte do tempo pelo aluno. Se eventualmente, por conta de algum gesto musical de ataque no início de uma música ou de arcadas longas que exijam um leve giro do tronco, o aluno deve retornar à sua posição base logo após o evento técnico musical.

Uma maneira de ajudar o aluno a entender esa posição e alinhamento é pedir que ele fique de costas contra uma parede, alinhando os calcanhares, o quadril e as costas inteiras na parede. Depois de feito isso por cinco segundos, pedir que dê um passo à frente e repetir essa sensação de estar encostado em uma parede imaginária.

\section{Fortalecimento e tonificação muscular}

No início do estudo no violino, os alunos estão com a musculatura dos braços despreparada para sustentar a posição do arco nas cordas e suportar o peso do instrumento. Mesmo as crianças mais fortes não estão acostumadas a usar os músculos específicos para os movimentos do violino. Por isso, muitas delas se cansam rapidamente, afrouxam a musculatura, perdem tonicidade e não conseguem sustentar a posição correta do instrumento e do arco.

Daí decorre a grande parte dos problemas enfrentados na classe de aula de uma turma iniciante. O professor se desgasta com um sem fim de repetições sobre a correção da postura dos alunos, como, por exemplo: manter o violino levantado sem deixar o cotovelo esquerdo se apoiar na barriga, manter o pulso esquerdo reto ou alinhado com o braço, não encostar o cotovelo direito no tórax, manter a coluna reta ou alinhada ao eixo, entre outros. Esses problemas são, em grande parte, solucionados por um trabalho de tonificação e fortalecimento da musculatura do tronco, dos braços e das pernas dos alunos.

\section{Exercício preparatório 8}

Como já citamos anteriormente, no capítulo 2.3.4 Noção do corpo, um bom exercício de tonificação é o "case walk" da metodologia de Paul Rolland ${ }^{20}$. O "case walk" ou, em tradução livre, "marcha com as caixas", é exatamente o que diz o seu nome: uma marcha com as caixas dos violinos.

\footnotetext{
${ }^{20}$ ROLLAND, Paul; MUTSCHLER, M. The Teaching of Action in String Playing. Chicago: Illinois University Press, 1974, p. 69.
} 
Os alunos são posicionados em fila, com os braços estendidos para frente, e com as palmas das mãos voltadas para cima. Nessa posição, o professor coloca as caixas dos instrumentos apoiadas no braço, na secção próxima ao tronco, sendo que os braços devem permanecer estendidos durante todo o exercício. A partir de uma melodia ritmada, os alunos são estimulados a cantar enquanto marcham, batendo com os pés no chão para marcar a pulsação rítmica.

A marcha pode ocorrer com os alunos marchando no mesmo lugar ou andando pela sala. No primeiro caso, o professor deve ensinar o aluno a marchar, ou seja, levantar o joelho para frente do corpo e bater com o pé no chão, de acordo com a pulsação da música e sempre no mesmo lugar. No segundo caso, sugerimos que, antes do início da marcha, o professor demarque o caminho por onde a marcha ocorrerá, estabelecendo pontos de referência, como, por exemplo, colocar duas cadeiras em pontos opostos na sala e demonstrar o trajeto que os alunos vão realizar. Em seguida, deve treinar com os alunos, batendo com os pés no ritmo sem sair do lugar e também marchando em fila indiana pelo trajeto planejado.

O segundo exercício de marcha apontado por Rolland é feito de forma semelhante ao primeiro, com a variação de que os braços não estão estendidos para frente do corpo, mas segurando a caixa de violino acima da cabeça. A realização desses exercícios de marcha deve ocorrer sempre no início das aulas; a cada dia, aumenta-se uma volta ou uma repetição da música.

\section{Exercício preparatório 9}

Outro grupo muscular que merece a nossa atenção são os que dão sustentação à coluna, não somente aqueles situados nas costas, como os situados no abdome, a saber: o oblíquo interno e o externo; o reto do abdome; e particularmente, o músculo situado na parte mais interna, o transverso do abdome; além dos músculos do assoalho pélvico. O seu fortalecimento é essencial para garantir a distribuição adequada do peso corporal a ser sustentado pela coluna e não sobrecarregá-la.

Em geral, os músculos da parede abdominal anterior são semelhantes aos músculos intercostais da parede torácica em termos de orientação. O músculo mais profundo é o transverso do abdome, que corresponde ao músculo intercostal mais interno, que é bem grosso. O transverso encerra as fibras inferiores do reto, depois soma-se à camada posterior da bainha do reto. O reto do abdome se 
origina em segmentos conectados por tendões planos... e é um flexor da coluna vertebral. As fibras dos oblíquos externo e interno são orientadas a 90 graus uma com relação a outra ... Estes músculos são ativos na compressão do conteúdo abdominal, como no estiramento, e contribuem para a flexão e rotação do dorso. Todos esses músculos se tornam ativos nos exercícios de sentar e levantar. (KAPIT; ELSON, 1987, p. 28)

A contração do transverso abdominal resulta em redução da circunferência abdominal... Onde foi demonstrado, por meio da ressonância magnética, que a ativação dessa musculatura melhora a estabilização da região lombo-pélvica. ${ }^{21}$

Sugerimos o seguinte procedimento, adaptado dos exercícios de fisioterapia e desenvolvimento motor: o aluno deve ficar sentado em uma cadeira, sem perder o eixo vertical, e procurar sentir os dois ossos da zona inferior do quadril, que são os ísquios, e sustentam o nosso corpo quando estamos sentados. O fortalecimento da musculatura do transverso e do assoalho pélvico é feito quando se tenta aproximar as musculaturas ao redor dos ísquios, cuja sensação é a mesma ao tentar reter fezes e urina do aparelho intestinal e da bexiga.

O aluno deve inspirar profundamente, retendo o ar por cinco segundos, enquanto contrai a musculatura dos ísquios e do abdome na linha da pélvis. A seguir, ele deve encostar a língua no céu da boca, como se quisesse afastar a cabeça dos ombros. Por fim, expirar lentamente enquanto mantém a contração do abdome e abaixa o osso do externo, situado no meio dos pulmões. Esse procedimento deve ser repetido quatro vezes.

Ao realizar esses exercícios no período de quatro semanas de aulas, com duas aulas semanais, poderemos constatar uma diferença substancial na tonicidade geral dos alunos, que se refletirá na manutenção da postura correta do violino e do arco por muito mais tempo, sem sinais de cansaço durante todo o período da aula.

\section{Alongamento}

O alongamento é uma parte essencial do aprendizado do violino, pois ao alongar o corpo evitamos uma série de problemas com o acúmulo de tensão nos músculos e tendões, com seu encurtamento a longo prazo e com problemas relativos a lesões por esforço repetitivo (LER), como a tendinite, a bursite e outras inflamações musculares e dos tendões.

\footnotetext{
${ }^{21}$ Disponível em: <<www.itcvertebral.com.br/instabilidade-vertebral/instabilidade-vertebral>>. Acesso em: 07 julho 2012.
} 
Sugerimos, a seguir, quatro exercícios de alongamento criados a partir dos exercícios de desenvolvimento motor:

\section{Exercício preparatório 10}

Com os pés apoiados no chão, realizar o alongamento das costas ao inclinar o tronco para frente, encostando os pés com as mãos, sem dobrar os joelhos. Permanecer assim por 5 segundos. Se não for possível alcançar os pés, o aluno não deve forçar o movimento, mas tentar chegar o mais perto possível.

\section{Exercício preparatório 11}

De pé em frente a uma cadeira, segurar com as duas mãos o encosto da cadeira e, sem dobrar os joelhos, abaixar a cabeça e o tronco até formar um ângulo reto entre o tronco e as pernas. Este exercício tem por objetivo alongar os músculos das costas. Permanecer por 15 segundos.

\section{Exercício preparatório 12}

De pé em frente a uma cadeira, agora o aluno deve segurar com as duas mãos no assento da cadeira, manter o alinhamento da cabeça e tronco, e realizar movimentos de abaixar e levantar os quadris, dobrando os joelhos para isso. As mãos devem permanecer segurando o assento da cadeira o tempo todo. Repetir quatro vezes este alongamento.

\section{Exercício preparatório 13}

Ficar de costas para uma parede a uma distância de $50 \mathrm{~cm}$ e se inclinar para trás até as mãos encontrarem a parede, dando apoio para o peso do corpo. A coluna forma um arco para trás em relação à parede. $\mathrm{O}$ aluno pode descer até a altura que suportar o peso do corpo sem cair.

\subsection{EXERCÍCIOS PREPARATÓRIOS PARA MÃOS E BRAÇOS}

Os exercícios preparatórios para mãos e braços são fundamentais para desenvolver os sentidos táteis e cinestésicos: o relaxamento muscular em volta das 
juntas e articulações e a coordenação e a independência dos movimentos dos braços, das mãos e dos dedos.

O sentido do tato é fundamental para o aprendizado no instrumento. É através do tato que sentimos a espessura das cordas e dosamos a pressão que exercemos sobre elas contra o espelho do violino. Sem o tato não saberíamos o quanto estamos pressionando as cordas e, consequentemente, não conseguiríamos tocar com afinação. Se exercermos pressão demais na corda, a nota se distorce para os agudos; se a pressão for insuficiente, desafinamos em direção aos graves, além de produzirmos uma nota de afinação imprecisa. Também não conseguiríamos realizar as mudanças de posição no violino, pois não saberíamos quando e quanto aplicar ou afrouxar a pressão dos dedos e nem quando parar o movimento da mão esquerda.

Além disso, é o tato que nos permite fazer os microajustes na mão direita ao perceber os movimentos mais leves e delicados que o arco faz enquanto corre sobre as cordas, para controlar a pressão que exercemos sobre o arco na realização do ataque das notas, na clareza e na definição das articulações musicais, nas mudanças de dinâmica e nas nuances timbrísticas dos fraseados musicais.

Para desenvolver o sentido do tato, Kovács e Pásztor (2010, p. 22-23) afirmam que:

La mejor herramienta para refinar el sentido del tato es el globo, porque su ligereza nos indica inmediatamente si se ha cometido un error. Si lo tocas con delicadeza y sensibilidad será obediente, pero un toque brusco hará que se escape.

Em tradução livre, os autores dizem que a melhor ferramenta para refinar o sentido do tato é o balão redondo em forma de globo, porque sua leveza e resposta ligeira nos indica imediatamente se cometemos algum erro no movimento. Se o manuseamos com delicadeza e sensibilidade, ele nos obedecerá, porém um toque mais brusco fará com que escape de nossas mãos.

Kovács enfatiza a importância de o balão ser redondo, e não oval, para manter a regularidade na resposta ao nosso toque por causa do seu formato. Descrevemos, a seguir, oito exercícios do método de Kovács para as mãos e os braços, lembrando que esses exercícios são sempre realizados com o aluno em pé e com a musculatura relaxada; caso contrário, o balão não se movimenta adequadamente: 


\section{Exercício preparatório 14}

Segurar o balão com as duas mãos na frente do corpo e jogar o balão para trás do corpo. $O$ aluno deve conseguir segurar o balão com as duas mãos nas costas, sem virar o tronco. Esse exercício desenvolve o nosso sentido tátil, pois precisamos segurar o balão nas costas com leveza, assim como desenvolve o senso rítmico, ao demandar o cálculo do tempo de descida do balão até ser alcançado pelas mãos.

\section{Exercício preparatório 15}

Bater levemente no balão com a palma da mão relaxada e deixar que repique no chão. Aproveitar a subida do balão para efetuar o próximo movimento, sem fazer barulho.

Esse exercício deve ser feito com uma mão de cada vez e, depois, alternando as mãos a cada batida. Por meio desse exercício, desenvolve-se a flexibilidade e o relaxamento das articulações da mão, que deve estar relaxada para efetuar o rebote do balão.

\section{Exercício preparatório 16}

Realizar o mesmo movimento do exercício anterior, só que, desta vez, na subida do balão até a linha da cintura, rebater usando apenas um dedo da mão direita, alternando os dedos a cada vez.

Repetir, usando os dedos da mão esquerda. Esse exercício e o próximo desenvolvem a independência dos dedos, além de criar sensibilidade tátil na ponta deles.

\section{Exercício preparatório 17}

Lançar o balão para cima em linha reta. Quando ele cair e estiver na altura do cotovelo, usar um dedo da mão direita para jogá-lo novamente para cima, alternando os dedos. A palma da mão deve estar voltada para cima. Repetir os movimentos, usando os dedos da mão esquerda.

\section{Exercício preparatório 18}

Lançar o balão para cima com a ponta dos ombros, alternando ambos os lados. Esse movimento deve ser leve e ágil, e o aluno deve relaxar os ombros logo 
após o movimento. Dessa forma, o exercício relaxa a musculatura da região, além de ajudar a corrigir a postura de quem possui ombros caídos ou com grande inclinação.

\section{Exercício preparatório 19}

Bater levemente no balão em direção ao chão com a lateral da mão direita, logo abaixo do dedo mínimo. Na subida do balão, bater nele com a outra mão. Esse exercício ajuda a relaxar o pulso.

\section{Exercício preparatório 20}

Lançar o balão para cima com a ponta das unhas da mão direita, cuja palma fica voltada ao chão. Alternar o uso de cada dedo e depois repetir os movimentos com a outra mão. Esse exercício fortalece, ao mesmo em tempo que relaxa, os músculos extensores no dorso das mãos, que são os mais débeis da mão, e os que mais geram problemas com sua inflamação.

\section{Exercício preparatório 21}

Jogar o balão para cima e bater nele com o lado interno dos cotovelos para mantê-lo no ar. Repetir o exercício, batendo com o lado externo dos cotovelos. Esse movimento ajuda a relaxar e a preparar os braços para os movimentos do arco e do violino, uma vez que efetua o giro e a elevação do cotovelo esquerdo no violino e do cotovelo direito no arco.

\subsubsection{O Arco}

A partir dos princípios psicomotores, elaboramos a seguir uma série de procedimentos para o aprendizado da mão direita no arco. Tais exercícios foram criados tendo em vista uma turma de ensino coletivo de violino composta por crianças de 6 a 7 anos, que é a nossa primeira faixa etária eleita.

Crianças em idades superiores a essas apresentarão desenvolvimentos motor e de coordenação psicomotora mais apurados e amadurecidos do que as de idade menor. Portanto, o fator tempo é uma das poucas variáveis nesse processo de 
aprendizado, na comparação dos resultados obtidos com a aplicação dos exercícios preparatórios em crianças de 6 a 7 anos e com as maiores.

Ressaltamos a importância de se respeitar a ordem e a sequência dos exercícios, que devem ser ensinados logo no início do aprendizado do aluno.

\section{Movimentos giratórios}

Depois de aprender a ficar de pé em equilíbrio, o aluno deve aprender sobre a gênese dos movimentos que realiza ao violino a partir dos movimentos giratórios. Os exercícios são os seguintes:

\section{Exercício preparatório 22}

Girar um dos braços de trás para frente, elevando-o acima da cabeça com a palma voltada para a frente do corpo e pender em direção ao chão sem dobrar o cotovelo, deixando o peso do braço conduzir a rotação.

Explicar ao aluno a diferença entre um movimento em que a musculatura do braço controla cada instante do movimento, o que não é desejável para nossos objetivos, e aquele em que o peso do braço funciona como um pêndulo, impulsionando o braço para baixo e apenas controlando parcialmente a sua subida, 0 que é o ideal. Nesse movimento ideal, aproveitamos a força gerada pelo peso do braço em movimento descendente para gerar impulso para o movimento ascendente.

Esse exercício desperta a consciência do aluno para a articulação dos ombros e promove o relaxamento muscular dessa região.

Depois de realizar quatro giros para a frente, inverter o sentido da rotação, praticando mais quatro giros. Repetir tudo com o outro braço.

\section{Exercício preparatório 23}

Este exercício é uma variação do exercício anterior. O aluno deve ficar de frente para um suporte, como uma estante de madeira, o encosto de uma cadeira ou uma mesa. O primeiro braço a ser exercitado é o direito.

Ao realizar o giro de trás para frente, quando o braço direito estiver descendo até a altura dos ombros, parar subitamente o movimento, deixando a mão pender no suporte, tomando o cuidado para não machucar a mão batendo com força no suporte. 
Ressaltamos que o movimento válido é apenas aquele em que o braço se aproveita do próprio peso para realizar seu impulso de movimentação, e não aquele em que os músculos do braço controlam o movimento sustentando o conjunto todo.

A mão deve pousar e ficar pendurada apenas pelos dedos no suporte, deixando o resto do braço relaxado. A força exercida pelos dedos no suporte deve ser mínima, somente o suficiente para não deixar cair o braço pendente.

Essa é a força que a mão deve exercer no arco, a mínima possível, somente para manter o arco seguro na mão sem cair. O resto da força empregada pelo arco nas cordas deve provir, em sua grande parte, da transferência de peso do braço para o arco, e não da pressão deliberada dos dedos ou da mão sobre a vareta.

Repetir o exercício com o braço esquerdo. A força mínima que a mão esquerda exerce para não deixar o braço escorregar do suporte é a que deve ser empregada para prender os dedos nas cordas. Abordaremos esse detalhe da mão esquerda logo adiante, no capítulo 3.2.2 O violino.

\section{Exercício preparatório 24}

Este exercício vai diminuir o raio do movimento giratório anterior, que deixa de usar o braço inteiro para movimentar apenas o antebraço. $O$ aluno deve girar o antebraço direito quatro vezes no sentido horário e depois no anti-horário.

Em um segundo momento, o aluno deve esticar o braço esquerdo para a frente do corpo e continuar o giro do antebraço direito no sentido anti-horário, ou seja, da direita para a esquerda. Na metade do movimento descendente, o aluno deve parar o giro pousando a mão direita no antebraço esquerdo, que está esticado para servir de apoio.

Essa parada obedece às mesmas condições do exercício preparatório 23, ou seja, a mão direita deve usar um mínimo de força para se segurar no outro braço. Esse é o movimento incorporado na maioria dos golpes de arco com arcada para baixo, no sentido do talão até a ponta. O movimento no sentido horário responde pelas arcadas para cima, no sentido da ponta até o talão.

Repetir todo o exercício, girando agora o antebraço esquerdo e pousando no braço direito. Voltaremos a citar esse exercício feito pelo antebraço esquerdo no próximo capítulo 3.2.2 O violino. 


\section{Exercício preparatório 25}

Mais uma vez o movimento vai diminuir o seu raio, e agora passa a se limitar à rotação do pulso. $O$ aluno deve girar quatro vezes o pulso direito no sentido horário e depois no anti-horário.

Quando a rotação é no sentido anti-horário, o pulso realiza o movimento de pronação; quando a rotação acontece no sentido horário, o pulso realiza o movimento de supinação. Esses são os dois movimentos originadores da grande maioria dos golpes de arco, como a mudança de direção do arco, o detaché, o staccato, entre outros.

\section{Postura da mão direita}

\section{Exercício preparatório 26}

Este exercício se concentra no uso dos dedos, promovendo relaxamento e soltura, sem travas nas articulações. O aluno deve realizar este exercício sentado junto a uma mesa e apoiar o pulso e as duas mãos em cima dela com a musculatura relaxada. Os dedos das mãos devem se manter curvos, como se estivessem segurando uma bola no centro das palmas das mãos.

O primeiro movimento é aproximar a palma da mão até a mesa, sem deixar nenhuma articulação travar, ou seja, imitar o movimento de mola, dobrando todas as juntas dos dedos. Repetir esse exercício com as duas mãos por quatro vezes.

No segundo movimento, a mão segura um lápis que está deitado na mesa, com a ponta dos dedos, que devem permanecer curvos. O aluno realiza o mesmo movimento anterior, aproximando a palma da mão do lápis na mesa.

\section{Exercício preparatório 27}

A partir de elementos familiares ao universo infantil, como o lápis, iniciamos o aprendizado da postura do arco. Essa abordagem é semelhante aos métodos 
consagrados de ensino coletivo, como All for Strings ${ }^{22}$, String Builder ${ }^{23}$, Paul Rolland ${ }^{24}$, entre outros.

Nesse exercício ensinamos três formas de segurar o lápis com a mão direita, que é o protótipo do uso do arco. O aluno é estimulado a estudar as três formas antes de escolher uma maneira que mais o agrade ou que seja mais fácil para ele. Esse exercício deve ser feito em pé.

$\mathrm{Na}$ primeira forma, o aluno segura o lápis com a ponta dos dedos da mão direita, lembrando-se de manter os dedos curvos e um espaço no meio da palma da mão. O aluno deve segurar o lápis na posição horizontal paralelo ao chão, alinhar o polegar junto do dedo médio e pronar a mão levemente em direção à proximal do indicador, ou seja, inclinar um pouco a mão em direção à primeira articulação do dedo indicador.

Nessa posição, o aluno deve encostar a falange média do indicador (situada entre a falange da ponta do dedo e a falange próxima da palma da mão) no lápis. A ponta do dedo médio desce do lápis em direção ao chão e encosta a sua falange média no lápis na parte interna do dedo. O dedo anular acompanha o dedo médio, e o dedo mínimo permanece com a ponta em cima do lápis.

$\mathrm{Na}$ segunda forma, o aluno imita com os dedos a cabeça de um coelho, semelhante ao método Suzuki ${ }^{25}$. O polegar faz oposição ao dedo médio na altura da prega interfalangeal distal, ou seja, a última dobra do dedo antes de chegar à ponta. Forma-se um círculo entre o polegar e o dedo médio.

A seguir, um lápis é colocado no ponto de contato desses dois dedos, como se a figura do coelho formado estivesse mordiscando uma cenoura. O próximo passo é deitar o indicador na falange média em cima do lápis e manter o dedo mínimo em pé e curvo no lápis.

$\mathrm{Na}$ terceira forma, o aluno deve virar a palma da mão para o teto, com os dedos relaxados e mantendo a forma circular dos dedos. Com uma caneta, o professor deve pintar os pontos de contato mais importantes da mão direita, que

\footnotetext{
${ }^{22}$ ANDERSON, G.E.; FROST, R.S. All for Strings: Comprehensive String Method. San Diego: Kjós Neil A. Kjós Music Company, 1986.

${ }^{23}$ APPLEBAUM, Samuel. String Builder: a String Class Method for Class or Individual Study. New York: Belwin Mills, 1960.

${ }^{24}$ ROLLAND, Paul; MUTSCHLER, M. The Teaching of Action in String Playing. Chicago, Illinois: University Press, 1974.

${ }^{25}$ SUZUKI, Shinichi et al. The Suzuki Concept: An Introduction to a successful Method for Early Music Education. Editado por Elisabeth Mills e Therese C. Murphy. Berkeley, Califórnia: Diablo Press, 1973.
} 
ficarão em contato com o arco, a saber, a ponta do polegar, a ponta do mínimo e a lateral do indicador na sua falange média.

O aluno deve agora segurar o lápis com a mão esquerda e colocá-lo nas marcas pintadas da mão direita, unindo os pontos de contato. Uma vez que o polegar se alinhou ao dedo médio, o aluno deve virar a mão, com a palma apontada ao chão, como na posição do arco no violino.

O próximo passo é substituir o lápis pelo arco e refazer todas as três formas de posicionamento do arco citadas acima. A mão esquerda ajudará na sustentação do arco, segurando-o pela vareta na metade superior, entre o meio e a ponta, enquanto a mão direita realiza os exercícios.

Alguns pontos essenciais a serem constantemente lembrados aos alunos: manter sempre a musculatura da mão direita relaxada e segurar o arco com o mínimo de esforço; manter a forma dos dedos naturalmente curvos, principalmente o polegar e mínimo; o polegar deve se acomodar na vareta ao mesmo tempo em que encosta a face interna do dedo na castanha, sem nunca permitir que o polegar se aloje dentro da castanha do arco; o dedo mínimo deve ser posicionado em cima da vareta, sem encostar no parafuso do arco; o dedo anular se posiciona com a polpa da ponta dos dedos apontada para o centro da vareta, e o dedo médio o acompanha na mesma posição.

Para melhor efeito da transferência de peso do braço direito para o arco, recomendamos adotar uma posição levemente pronada da mão direita, ou seja, com um leve giro da mão em direção ao indicador.

\section{Exercício preparatório 28}

Uma vez realizado o exercício preparatório 27 e tendo estabelecido a postura da mão direita ao arco, o aluno deve realizar exercícios de fortalecimento da empunhadura do arco. Cada aluno deve realizar este exercício em pé, junto de outro colega, com um arco para a dupla.

Um aluno segura o arco na ponta pela vareta, enquanto o outro irá realizar o exercício posicionando a mão direita sobre o talão. $\mathrm{O}$ arco deve ser posicionado na horizontal. $O$ aluno que irá praticar o exercício deve tentar puxar o arco, como se estivesse tocando com uma arcada para baixo no sentido do talão até a ponta, enquanto o outro colega que está segurando na ponta pela vareta irá resistir, sem permitir que o arco seja puxado. 
Deve ser feita uma série de oito repetições. Depois, em vez de puxar o arco para baixo, o aluno irá empurrar o arco, como se estivesse tocando uma arcada para cima, no sentido da ponta até o talão. No final, invertem-se os pares, para que o outro aluno também se exercite.

O intuito desse exercício é treinar a firmeza da empunhadura da mão direita. Deve-se lembrar de que, a todo o momento, a postura da mão não deve se alterar, de acordo com o modelo do exercício anterior.

\section{Exercício preparatório 29}

Este exercício deve ser realizado com o aluno posicionado em pé, segurando o arco com a mão direita, com o braço direito esticado para a frente do corpo na altura dos ombros, e o arco na posição vertical.

O aluno deve realizar um giro de 180 graus para a esquerda em movimento de pronação, voltar à posição inicial de arco em pé e depois girar 180 graus para a direita em movimento de supinação. Repetir quatro vezes essa série.

É importante lembrar que o braço deve permanecer esticado durante todo o movimento e de realizar o movimento a partir da rotação do pulso, e não do cotovelo, que apenas acompanha o movimento.

Esse exercício permite que o aluno experimente a variação do apoio do arco em cada um dos dedos da mão direita, pois, ao realizar o giro, o peso do arco se transfere do indicador para o mínimo e vice-versa.

\section{Exercício preparatório 30}

Este exercício deve ser feito com o aluno em pé, com um pano de flanela apoiado no ombro esquerdo. O arco, seguro pela mão direita, será apoiado nessa flanela. O dedo mínimo exercerá uma força maior que os outros dedos, o suficiente para fazer levantar o arco da flanela, repousando-o logo em seguida, deixando o arco retornar à flanela. Repetir esse movimento quatro vezes.

O objetivo desse exercício é fortalecer o dedo mínimo, que tem a importante função de suportar o peso da vareta quando o arco vai para o talão.

\section{Preparação para o uso do arco}

\section{Exercício preparatório 31}


Este exercício deve ser realizado com a participação de um material alternativo, que é um rolo de papelão, que pode ser encontrado no miolo de papel higiênico ou de papel toalha e medir de 10 a $15 \mathrm{~cm}$ para ser funcional. $O$ uso do rolo de papelão em exercícios com arco é comum em metodologias de ensino coletivo, como, por exemplo, a de Paul Rolland ${ }^{26}$.

Nosso exercício com o rolo é realizado em duas partes: a primeira com o uso do lápis na mão direita e depois com o arco. A mão esquerda deve segurar o rolo em cima do ombro esquerdo, mantendo-se imóvel nessa posição.

O aluno deve montar sua mão direita no lápis na posição descrita no exercício preparatório 27 e colocar o lápis dentro do rolo com o dorso da mão virado para cima e com o pulso levemente curvado. O cotovelo direito deve ser posicionado um pouco mais baixo que o pulso. Na posição inicial, as duas mãos se encostam, juntas no ombro esquerdo.

O exercício consiste em estender a mão direita para frente do corpo, como se estivesse atirando uma flecha em um alvo imaginário situado na frente do tronco do aluno. O que ocorre na maioria das vezes em que esse exercício é feito pela primeira vez é que o aluno estica o braço direito sem ajeitar a posição do pulso, mantendo uma linha reta entre braço, antebraço e pulso. Dessa maneira, no final do movimento, quando o braço já estiver esticado, o lápis apontará para os lados e não para a frente do aluno. Por isso, é importante enfatizar a imagem mental do alvo situado à frente e não dos lados do aluno, pois assim, instintivamente, o aluno ajeitará o pulso na posição correta, que corresponde à postura da mão direita no arco quando estiver tocando na ponta.

Outra dificuldade comum é o aluno prolongar demais a extensão do braço, ocasionando a perda do eixo horizontal. Para evitar que isso aconteça, é importante demonstrar como ele pode esticar o braço sem deslocar o ombro para frente. Sugerimos o seguinte procedimento: pedir ao aluno que fique em pé, encostando os ombros e os quadris na parede, e estender o braço direito para frente sem tirar os ombros da parede. A seguir, pedir-lhe que dê um passo à frente, desencostando-se da parede e, sem perder o eixo horizontal formado pela linha dos ombros e quadris, repita o mesmo movimento de braço.

\footnotetext{
${ }^{26}$ ROLLAND, Paul; MUTSCHLER, M. The Teaching of Action in String Playing. Chicago, Illinois: University Press, 1974, pg. 85.
} 
Uma boa maneira de explicar esse movimento é propôr aos alunos um jogo do certo ou errado, ou seja, primeiro pedir ao aluno que faça o movimento errado, com os ombros deslocados no esforço de estender o braço direito, tensionando os músculos e causando grande desconforto. Em seguida, pedir-lhe que volte o ombro à posição original de repouso. Assim, ao entrar no alinhamento do eixo horizontal, ele experimentará alívio pelo término da tensão muscular. Essa sensação de alívio ficará gravada na memória do aluno como uma sensação de conforto e bem-estar, a qual ele buscará toda vez que estender o braço direito para frente nas arcadas para baixo em direção à ponta.

Uma vez realizado corretamente o exercício com o lápis, repetir o mesmo usando o arco, que será colocado dentro do tubo, encostando uma mão na outra em cima do ombro esquerdo. O arco deve ficar na posição horizontal, paralelo ao chão, para evitar que o cotovelo direito encoste no tórax.

O aluno deve puxar o arco de dentro do tubo até a ponta e voltar para o talão, realizando arcadas para baixo e para cima, usando toda a extensão do arco, sem, contudo, tirar o dedo mínimo da vareta e perder contato com o arco. Repetir esse movimento por oito vezes.

Se o aluno ainda não consegue puxar o arco até a ponta sem tirar o dedo mínimo da vareta, o professor deve marcar com fita adesiva o lugar na vareta do arco onde o aluno deve parar de puxar o arco, antes do dedo mínimo sair. Essa região será a "ponta provisória" do arco do aluno, de modo que todos os dedos permaneçam em contato com o arco o tempo todo. De acordo com o ritmo de crescimento corporal do aluno, essa ponta provisória pode ser ampliada até se chegar à ponta real do arco.

\section{Exercício preparatório 32}

Este exercício deve ser realizado com uso de um material alternativo, que é a caixa de papelão que acondiciona uma dúzia de ovos de galinha, encontrada em supermercados e avícolas.

O aluno deve acomodar a caixa de papelão no ombro esquerdo, alinhada ao eixo horizontal, isto é, a tampa da caixa deve encostar no ombro, uma das extremidades no pescoço e a outra ser segura pela mão esquerda. Enquanto isso, a mão direita posiciona o arco em uma das cinco ranhuras do fundo da caixa.

O tamanho da caixa de ovos se assemelha ao tamanho do corpo do violino, com a vantagem de ser muito mais leve. Como o aluno não precisa sustentar o peso 
do violino, ele realiza esse exercício sem forçar a musculatura. Além do mais, as ranhuras da parte mais funda da caixa garantem o traçado feito pelo arco, pois se assemelha ao caminho trilhado pelo arco na corda, paralelo ao cavalete do violino.

O material com que é feito a caixa deve ser de papelão e não de plástico ou isopor, pois o papelão garante um atrito que se aproxima do toque e da fricção do arco nas cordas do violino.

O aluno deve puxar o arco na caixa de ovos, desde o talão até a ponta, e parar para examinar a postura de sua mão direita: verificar se a mão continua com a musculatura flexível e com um mínimo de tensão.

A seguir, propomos os seguintes exercícios rítmicos a serem realizados com o arco no "violino de caixa de ovos", lembrando que o aluno deve usar sempre toda a extensão do arco, do talão à ponta e vice-versa:

- Quatro semínimas, que devem ser tocadas enquanto o aluno pronuncia em voz alta uma palavra com quatro sílabas, falando uma sílaba por arcada, como, por exemplo:

VI O LI NO

- Duas mínimas, que devem ser tocadas enquanto o aluno pronuncia em voz alta uma palavra dissílaba, falando uma sílaba por arcada, como, por exemplo:

AR ---- CO ----

A linha horizontal escrita ao lado da sílaba representa a duração da mínima.

- Duas semínimas e uma mínima, que devem ser tocadas enquanto o aluno pronuncia em voz alta uma palavra trissílaba oxítona para dar a intenção do tempo mais longo da mínima, falando uma sílaba por arcada, por exemplo:

\section{ES TU DAR --.-}

- Uma semínima, uma mínima e outra semínima, formando uma síncopa, que deve ser tocada enquanto o aluno pronuncia em voz alta uma palavra trissílaba paroxítona para dar a intenção musical da síncopa, falando uma sílaba por arcada, por exemplo:

VI O ---- LA 
O uso das sílabas das palavras para ajudar o aluno a compreender e realizar exercícios rítmicos é um recurso comum das metodologias de ensino coletivo tradicionais como o All for Strings ${ }^{27}$, o método Suzuki, entre outros.

\section{Exercício preparatório 33}

Este exercício deve ser realizado com o arco na caixa de ovos, citada no exercício anterior. O objetivo aqui é desenvolver os movimentos circulares do arco, tanto em arcadas para baixo como para cima.

O aluno deve se posicionar de pé, segurando a caixa de ovos sobre o ombro esquerdo com a mão esquerda, e colocar o arco no talão sobre uma das ranhuras do fundo da caixa.

O arco deve ser puxado do talão até a ponta, e o aluno deve recolocar o arco na posição inicial no talão, descrevendo um semicírculo no ar com a mão direita. Esse movimento é o da retomada de arco, em arcadas para baixo. Repetir esse exercício quatro vezes.

Em seguida, o aluno posiciona o arco na ponta em uma das ranhuras da caixa de ovos. Agora ele fará o movimento contrário ao anterior, empurrando o arco da ponta até o talão e recolocando o arco na ponta, fazendo um semicírculo no ar com a mão direita.

É importante lembrar ao aluno de que todos os movimentos feitos nesse exercício são derivados de movimentos circulares que ele já praticou anteriormente.

\section{Exercício preparatório 34}

Este exercício deve ser executado após o aluno aprender a colocar o violino no ombro esquerdo. $O$ arco deve ser posicionado na região do meio da vareta e paralelo ao cavalete, na linha média entre o cavalete e o espelho.

O conjunto formato pelo braço, cotovelo, antebraço e pulso direitos forma um sistema de alavancas que, bem ajustadas, funcionam na transferência do peso do braço para o arco e finalmente para a corda do violino. Para isso acontecer com perfeição, é preciso manter um equilíbrio entre os dois lados da balança, de um lado formado pelo braço, e do outro, pelo arco na corda.

\footnotetext{
${ }^{27}$ ANDERSON, G.E.; FROST, R.S. All for Strings: Comprehensive String Method. San Diego: Kjós Neil A. Kjós Music Company, 1986, livro do professor, p. 16.
} 
O aluno deve manter 0 arco na quarta corda, a corda sol. Sem alterar a proporção no conjunto do braço, descer para a terceira corda e depois para a segunda, até chegar à primeira corda, a corda mi. Depois o aluno deve voltar da primeira até a quarta corda. Tudo isso deve ser realizado sem produção de som e sem retirar o arco das cordas do violino.

O objetivo desse exercício é aprender a posicionar o arco no ângulo de cada corda e sem esbarrar nas demais cordas. É importante lembrar que é o cotovelo quem guia a mudança do conjunto todo no posicionamento em cada corda. Esse exercício de mudança silenciosa das cordas deve ser feito inclinando o arco suavemente de uma corda à outra, sem movimentos bruscos de salto entre elas.

\subsubsection{O Violino}

A colocação do violino no ombro da criança é um processo delicado, que não deve ser apressado por causa do grande risco de se posicionar erradamente e gerar uma tensão muscular que acompanhará a trajetória da criança no instrumento, ocasionando muitas dores no pescoço, ombros, braços, podendo afetar até o crescimento e desenvolvimento da coluna verterbral nas crianças.

O que frequentemente observamos é a dificuldade de as crianças sustentarem o peso do instrumento no ombro esquerdo por falta de uma tonicidade muscular adequada para essa tarefa. Por isso, além dos exercícios de fortalecimento da musculatura do corpo e dos braços já citados no início do capítulo 3, também desenvolvemos outros exercícios de tonificação do braço e da mão esquerdos, que consistem em utilizar o peso do próprio instrumento para essa tarefa, que detalhamos a seguir.

\section{Posicionamento do violino no ombro esquerdo}

\section{Exercício preparatório 35}

O violino é posicionado no ombro por meio de um tripé formado pela lateral da mandíbula, o ombro esquerdo e entre os dedos polegar e indicador da mão 
esquerda. Estes exercícios foram criados a partir do processo de colocação do violino no ombro, composto por quatro etapas de movimentos.

Na primeira etapa, o aluno segura o violino pela lateral do instrumento, com o polegar posicionado no fundo do violino e os outros quatro dedos da mão esquerda no tampo, estendendo o seu braço esquerdo para frente. O violino fica na posição vertical, com a voluta apontada para cima. Uma vez feito isso, ele deve elevar e abaixar todo o conjunto por 10 vezes, sempre com o braço esticado.

$\mathrm{Na}$ segunda etapa, o aluno apoia o fundo do violino sobre o braço esquerdo estendido e novamente executa 10 elevações com o violino nessa posição.

$\mathrm{Na}$ terceira etapa o violino é colocado encostado no ombro esquerdo, formando um ângulo de 45 graus em relação ao eixo dos ombros. Nesta etapa, o aluno deve observar se os ombros estão relaxados e não elevá-los na tentativa de segurar o violino. Pede-se ao aluno que gire a cabeça para direita e esquerda, sem apoiar o queixo na queixeira ainda. O ponto principal que deve ser enfatizado nesta etapa é a liberdade de movimentos da cabeça e dos ombros, sempre alinhados com o eixo vertical e sem gerar tensão de nenhuma espécie.

$\mathrm{Na}$ quarta etapa, a cabeça gira para a esquerda, sem, contudo, perder o eixo vertical, e descansa a lateral do queixo na queixeira. Esse movimento de colocação do queixo na queixeira do violino deve ser repetido várias vezes para fixar a sensação de liberdade de movimentos e a ausência de tensão muscular na memória cinestésica do aluno. Nessa última etapa, é primordial enfatizar ao aluno que é o peso da cabeça quem prende o violino ao ombro, e não a elevação forçada dos ombros ou a torção da cabeça sobre a queixeira.

\section{Exercício preparatório 36}

Este exercício tem como objetivo firmar a postura do violino e garantir a liberdade de movimentos do ombro e do braço esquerdos. Uma vez com o violino posicionado no ombro, a mão direita vai segurar o tampo pela lateral do violino, enquanto o aluno realiza movimentos circulares com o braço esquerdo, que vai girar por baixo e depois por cima do violino.

A segunda etapa deste exercício consiste em soltar a mão direita e repetir os giros de braço esquerdo por cima e por baixo do violino, tomando cuidado para que o violino não caia no chão. Repetir esses giros por quatro vezes. 


\section{Exercício preparatório 37}

Este exercício tem como objetivo firmar a postura do violino no ombro esquerdo, ao mesmo tempo em que tonifica a grande musculatura de sustentação da coluna e promove o equilíbrio corporal sem gerar tensão nos ombros.

$\mathrm{O}$ aluno deve colocar o violino no ombro esquerdo conforme o exercício anterior e deixar os braços pendentes relaxados. O professor pode escolher uma música que facilite a marcha, por exemplo, a canção infantil Marcha Soldado, e os alunos devem marchar pela sala, seguindo um trajeto já programado pelo professor, fazendo a marcação do ritmo com os pés ao mesmo tempo em que cantam a canção.

A própria movimentação da marcha promove um balanço natural dos braços, que relaxa a musculatura geral do corpo. O professor deve cuidar para que os alunos não deixem cair o violino enquanto marcham e também cuidar para não acontecer colisões entre os alunos durante o exercício.

\section{Exercício preparatório 38}

Este exercício tem como objetivo promover o relaxamento da musculatura do ombro esquerdo, ao mesmo tempo em que firma a postura do violino. O aluno deve realizar este exercício em pé, e seus braços devem pender relaxados ao lado do corpo.

Com o violino posicionado no ombro sem o apoio da mão esquerda, o aluno deve fazer giros com a voluta, como que desenhando pequenos círculos no ar. Realizar quatro giros no sentido horário e quatro no sentido anti-horário.

\section{Postura da mão esquerda no violino}

\section{Exercício preparatório 39}

Este exercício tem como objetivo posicionar a mão esquerda no violino com uso de uma tonicidade adequada.

A mão esquerda serve como apoio ao violino e encosta no braço do violino em dois pontos, entre os dedos polegar e o indicador. A postura da mão esquerda no violino também é dividida em quatro etapas, que devem ser observadas com atenção pelos alunos.

Uma vez colocado o violino no ombro esquerdo, a primeira etapa consiste em trazer o braço esquerdo do aluno para a frente do corpo e deixar o pulso reto, ou seja, 
o antebraço e o dorso da mão devem formar uma linha reta. O pulso deve ser mantido reto na maior parte do tempo, pois nessa posição ele permite uma movimentação livre dos dedos da mão esquerda.

A segunda etapa consiste em encontrar a prega digital proximal do indicador da mão esquerda, ou seja, a dobra da pele da primeira articulação que liga a palma da mão ao dedo indicador. O professor pode pintar uma marca nessa prega com caneta para que a criança a identifique. O aluno deve colocar essa marca junto à pestana do violino.

Na terceira etapa o aluno deve posicionar o polegar da mão esquerda no lado oposto ao da marca do indicador. A posição do polegar se situa na linha entre o dedo indicador e médio da mão esquerda, porém do outro lado do espelho.

O polegar deve estar relaxado, sem travas na sua articulação, encostando a lateral interna da falange distal na lateral do espelho e do braço do violino. $O$ aluno deve cuidar para não dobrar o polegar em cima do espelho, nem travá-lo embaixo do braço do instrumento. Para se certificar de que o polegar está relaxado, o aluno deve colocar e tirar o polegar da lateral do espelho do violino. Repetir esse movimento por quatro vezes.

$\mathrm{Na}$ quarta etapa, o aluno deve se certificar de não encostar a prega interdigital no braço do violino, ou seja, não encostar a dobra da pele que separa o dedo polegar do indicador, deixando sempre um espaço entre o braço do violino e a mão esquerda para permitir a liberdade de movimentos da mão esquerda sobre o espelho do violino. O aluno deve repetir esse procedimento de colocação da mão esquerda no violino por oito vezes.

\section{Exercício preparatório 40}

Este exercício tem como objetivo firmar a postura da mão esquerda no violino por meio da rotação do pulso esquerdo.

Uma vez tendo colocado a mão esquerda no violino, o aluno deve realizar movimentos de rotação do pulso esquerdo, girando a mão no sentido horário e no anti-horário. Essa rotação deve acontecer com o pulso reto, a marca da prega do indicador deve permanecer próximo à pestana e o polegar, no lado oposto do braço do violino. 
O movimento obtido nessa rotação é semelhante ao que exercemos ao trocar uma lâmpada incandescente do teto, quando desenroscamos e enroscamos a lâmpada no soquete. O pulso deve permanecer o tempo todo alinhado ao antebraço.

Com essa rotação, a lateral da palma da mão esquerda se afasta e se aproxima do espelho do violino, e o nosso objetivo aqui é manter essa lateral da palma o mais próximo possível do espelho. Então o aluno deve girar quatro vezes e depois terminar o movimento com a lateral da mão próxima do espelho.

Nessa posição, o quarto dedo ou o mínimo realizará mais facilmente sua tarefa nas cordas, uma vez que é o dedo mais curto da mão, e por isso devemos aproximá-lo o mais possível das cordas.

\section{Exercício preparatório 41}

Os dedos da mão esquerda devem tocar nas cordas do violino com a polpa da ponta dos dedos e permanecer curvos. Como o cavalete é curvo, para possibilitar que se toque em cada corda sem esbarrar nas demais, a mão deve acompanhar essa curvatura para que os dedos toquem nas cordas sempre com a mesma curvatura e o mesmo ângulo de contato.

Para que isso aconteça, o braço deve realizar um movimento giratório anti-horário de baixo para cima, semelhante ao movimento realizado pelo pugilista que atinge o queixo do seu oponente de baixo para cima. O braço esquerdo realiza esse movimento giratório em sua mudança de ângulo para se posicionar em cada corda do violino.

A observação desse princípio é de extrema importância para que o aluno consiga um relaxamento muscular do braço esquerdo, principalmente quando vai tocar na quarta corda ou nas mudanças de posição para alcançar as posições mais elevadas, com a mão acima do espelho.

É comum se ouvir nas aulas coletivas de violino que o cotovelo esquerdo deve girar para que os dedos da mão esquerda possam alcançar cada corda na posição correta. Porém, o que muitas vezes deixa de ser dito aos alunos é que esse giro do cotovelo é uma consequência da elevação da posição da mão e do braço, e não uma simples torção forçada do braço esquerdo.

Se o aluno não realiza a elevação adequada da mão esquerda, ele torcerá o braço para conseguir alcançar as cordas mais graves, o que é extremamente prejudicial à sua postura, uma vez que estará comprimindo os nervos e tendões que 
passam no meio do braço, causando dor e desconforto e até mesmo lesões e inflamações de seus tendões a médio e longo prazo.

Paul Rolland analisa a questão do posicionamento da primeira prega do indicador da mão esquerda, marcada com caneta no exercício anterior, em relação à borda do espelho do violino e classifica esse posicionamento em três elevações.

A primeira elevação é a baixa, quando a prega é colocada abaixo da borda do espelho. A segunda elevação é a média, quando a prega está alinhada com a borda do espelho. E a terceira elevação é a alta, quando a prega está acima da borda do espelho. Para tocar em cada corda, o aluno deve usar uma das elevações. $\mathrm{Na}$ primeira corda ele usará a elevação baixa e, conforme for tocar na segunda, na terceira e na quarta cordas, passará a usar as elevações média e alta.

Dependendo do formato da mão do aluno, ele usará, na maioria do tempo, uma das elevações. Rolland e Mutscheler (1974, p. 107) afirmam que:

As a rule, a broad hand with short fingers and thumb operates best when the elevation is low. A narrow hand with long fingers is usually more confortable with the high elevation.

Em tradução livre, os autores dizem que como regra geral, uma mão larga com dedos curtos desempenha melhor ao tocar com uma elevação baixa. Uma pessoa com mão estreita e dedos longos geralmente se sente mais confortável usando a elevação alta.

Para desenvolver o movimento giratório do braço esquerdo e as elevações da mão esquerda, sugerimos o seguinte exercício, que deve ser feito com os alunos formando pares, pois enquanto um aluno realiza o exercício, o outro o auxilia.

Com os pares de alunos de pé, o primeiro aluno deve segurar o violino no ombro esquerdo e deixar o braço esquerdo pendente em repouso. O segundo aluno vai auxiliar o primeiro, sustentando a voluta do violino.

O primeiro aluno vai então elevar o braço por meio de um movimento giratório anti-horário de baixo para cima. E, quando o braço esquerdo estiver acima do violino, ele deve deixar a mão esquerda cair sobre as cordas e se segurar no espelho do violino com um mínimo de força, somente o suficiente para se manter pendurado pelos dedos. A cada elevação, o aluno deve tentar deixar os quatro dedos presos em uma das cordas do violino, a começar pela primeira corda, passando para a próxima corda no próximo movimento. O segundo aluno deve sustentar firmemente o violino para não deixá-lo cair no chão. 
Esse movimento giratório deve ser repetido quatro vezes por cada aluno.

\section{Exercício preparatório 42}

Este exercício é uma variação do anterior e tem por objetivo desenvolver a transferência de peso do braço esquerdo para as cordas do violino.

Os alunos devem formar pares, com um aluno realizando o exercício e outro o auxiliando. O primeiro aluno vai realizar o movimento giratório do braço esquerdo de baixo para cima e pendurar a mão no espelho do violino, enquanto o segundo aluno sustenta a voluta do violino.

Agora o segundo aluno vai ajudar o primeiro a firmar os dedos nas cordas ao elevar o violino acima do ombro do colega por cerca de $5 \mathrm{~cm}$. O primeiro aluno deve soltar o queixo da queixeira para que essa elevação seja feita e não deve deixar a mão esquerda despencar do violino. Repetir esse exercício por quatro vezes.

Uma vez feita essa elevação, o braço esquerdo deve estar relaxado e apenas pendurado pelos dedos. É importante ressaltar que a força que o braço esquerdo exerce sobre a corda é suficiente para fazer o dedo pressionar a corda na hora de tocar uma nota dedilhada e que não é necessário fazer muita pressão com os dedos sobre as cordas. Isso evita que os alunos apertem demais os dedos nas cordas, causando tensão muscular na mão esquerda.

\section{Exercício preparatório 43}

Este exercício tem com objetivo estimular o sentido tátil cinestésico e a coordenação dos dedos da mão esquerda. Para desenvolver habilidades, como velocidade e independência dos dedos, devemos iniciar a estimulação por meio de exercícios que envolvam os grupos musculares globais do corpo para só depois ir refinando o movimento na praxia fina. Dividimos este exercício em três etapas.

$\mathrm{Na}$ primeira etapa do exercício, o aluno deve sentar-se numa cadeira, sem descanso para os braços e com as costas apoiadas no encosto, e realizar o movimento de subida e descida das pernas, alternadas e esticadas. O movimento é semelhante ao da natação, no estilo crawl, com o batimento contínuo das pernas alternadamente. Realizar oito repetições desse movimento.

Em seguida, o aluno deve realizar o mesmo movimento das pernas, mas agora com os braços esticados, em um movimento semelhante a uma tesoura gigante. Realizar oito repetições desse movimento. 
Depois, deve refinar o movimento até mexer com os dedos de ambas as mãos, que repetem o mesmo movimento realizado nas pernas e braços. O aluno continua sentado, mantendo os braços e todos os dedos esticados. Deve movimentar um par de dedos adjacentes de cada vez, iniciando pelo indicador e dedo médio, imitando o movimento de uma tesoura. Depois é a vez do par formado pelo dedo médio e o anular; o seguinte é o anular e o dedo mínimo; por fim, o par formado pelo polegar e o indicador. Os dedos das duas mãos realizam esse exercício simultaneamente. Repetir oito vezes esse movimento com cada par de dedos.

$\mathrm{Na}$ segunda etapa deste exercício, os dedos não ficam mais esticados, mas encurvados como na posição de repouso natural da mão. Com as mãos relaxadas, cada uma sobre uma coxa da perna, o aluno vai repetir as séries de movimentações anteriores com cada par de dedos. O pulso estará apoiado na perna, e os dedos devem ficar curvos e tocar a perna com suas pontas.

Depois de movimentar os dedos adjacentes, o aluno deve movimentar os dedos alternados, ou seja, primeiro o par formado pelo polegar e o dedo médio; depois o dedo indicador e o anular; e por fim o dedo médio e o mínimo. É importante ressaltar que enquanto o par de dedos escolhido realiza o movimento da tesoura, os outros dedos devem estar em repouso e sem perder contato com a perna. Realizar oito repetições desse movimento para cada par de dedos.

Agora, o aluno vai repetir o mesmo movimento com as mãos, subindo em várias regiões do corpo. Primeiro, com as mãos apoiadas, uma em cada lado da cintura, realizar o mesmo exercício na barriga. Depois cada mão vai segurar o cotovelo do outro braço e descer em direção ao punho. Por exemplo, a mão direita realizará o exercício na face interna do antebraço esquerdo, enquanto a mão esquerda realizará o exercício na face externa do antebraço direito.

Por fim, as mãos sobem cruzadas e descansam cada uma em um ombro. A mão direita se apoia no ombro esquerdo e a mão esquerda se apoia no ombro direito. Nessa posição, os alunos devem repetir o mesmo exercício de alternância dos dedos: primeiro trabalham os dedos adjacentes e depois os alternados.

$\mathrm{Na}$ terceira etapa, o aluno coloca o violino no ombro esquerdo e exercita apenas os dedos da mão esquerda. A mão esquerda se posiciona na lateral superior do violino, próximo à borda do espelho, com o polegar esquerdo apoiado no fundo do violino e os quatro dedos descansando curvos sobre o tampo. Ressaltamos a importância de se tocar apenas com a polpa da ponta dos dedos no tampo, sem 
deixar os dedos esticados. O aluno deve repetir o mesmo movimento de dedos adjacentes e alternados realizado anteriormente, mas agora sem a participação do polegar, que ficará o tempo todo apoiado no fundo do violino. 


\section{DIRETRIZES PARA O ENSINO COLETIVO DE VIOLINO}

As diretrizes para o ensino coletivo de violino oferecem ao professor uma série de alvos para seu planejamento pedagógico, considerando a diversidade das formações dos grupos e das realidades de ensino e, consequentemente, uma gama extensa de necessidades distintas e singulares.

A estruturação curricular do curso de ensino coletivo de violino é baseada em diversos fatores analisados no capítulo 1 da presente tese, e qualquer alteração nesses fatores interfere no resultado final. As diretrizes descritas neste capítulo 4 são orientações gerais que servem para todos os tipos de grupos de ensino coletivo de violino. O que varia é o tempo de sua aplicação de acordo com as condições de funcionamento de cada grupo.

Consideramos as seguintes condições como ideais para uma turma de ensino coletivo de violino:

a) Um mesmo professor ministrando todas as aulas;

b) Turmas homogêneas de violino com até 10 alunos;

c) Alunos com acesso ao instrumento para estudo diário;

d) Classes com três aulas de violino por semana;

e) Aulas com uma hora e meia de duração;

f) Ingresso de novos alunos limitado ao início do semestre;

g) Infraestrutura adequada do local de aulas, com piano ou teclado na sala, armário para instrumentos, espelho na parede para verificação da postura corporal, lousa e canetas.

h) Faixas etárias próximas entre os alunos. Sugerimos a seguinte divisão: turmas de 6 e 7 anos; turmas de 8 e 9 anos; turmas de 10 a 12 anos.

i) Duração do curso: módulos semestrais com 20 semanas letivas. Para turmas de 6 e 7 anos, duração de seis semestres; para turmas de 8 e 9 anos, duração de cinco semestres; e para turmas de 10 a 12 anos, duração de quatro semestres. 


\subsection{PARÂMETROS CURRICULARES PARA O ENSINO COLETIVO DE VIOLINO}

Os parâmetros curriculares foram desenvolvidos com base em observações sobre desenvolvimento das capacidades motoras e cognitivas das crianças, na estruturação da capacidade de percepção e apreciação musicais, assim como no aprendizado da teoria e da prática de instrumentos musicais, contemplando as diversas faixas etárias dos grupos de violino, de modo que possam servir de guia para o professor na condução de sua classe.

Os alvos pedagógicos foram organizados em três níveis de aprendizado: iniciante, intermediário e avançado. Esses níveis não correspondem necessariamente a períodos do ano letivo ou divisões rígidas de módulos de aprendizado. É uma classificação que indica o período do início do aprendizado, do desenvolvimento das capacidades técnicas e musicais, e o período do término do ensino coletivo de violino, quando o aluno deverá estar preparado para prosseguir seus estudos em aulas individuais e com uso de repertório erudito tradicional.

Em cada um dos níveis de aprendizados, os conteúdos foram organizados em tópicos, que devem ser assimilados em sua quase totalidade antes da passagem para o próximo tópico. Para a elaboração dos conteúdos descritos abaixo, junto ao nosso trabalho de pesquisa sobre o assunto acrescentamos uma adaptação de algumas orientações gerais da ASTA Curriculum $2012^{28}$, para atender às nossas necessidades pedagógicas.

\section{Nível iniciante}

\section{1a. Postura corporal global}

- apresentar uma postura corporal equilibrada, relaxada e sem tensões musculares ao segurar o instrumento;

- apresentar postura corporal sempre em prontidão para o movimento;

\footnotetext{
${ }^{28}$ BENHAM, Stephen J.; WAGNER, Mary L.; ATEN, Jane Linn; EVANS, Judith P.; ODEGAARD, Denese; LIEBERMAN, Julie Lyonn. ASTA Curriculum, Standards, Goals and Learning Sequences for Essential Skills and Knowledge in K-12 String Programs. Fairfax, VA, USA: American String Teachers Association, 2011 edition.
} 
- realizar a transferência e a distribuição do peso corporal naturalmente, tanto em pé como sentado.

\section{1b. Mão esquerda}

- posicionar todo o membro superior esquerdo na angulação correta;

- tocar com as posições do ombro, do braço, do antebraço, da mão e dos dedos esquerdos em equilíbrio e livre de tensões;

- desenvolver a independência dos dedos, o controle do peso e a pressão que os dedos exercem sobre as cordas.

\section{1c. Mão direita}

- usar o arco por meio de movimentos livres e naturais;

- conhecer as variáveis expressivas do arco, como peso, ângulo, velocidade e ponto de contato;

- tocar pizzicato;

- estabelecer a postura inicial do arco;

- realizar os exercícios preparatórios para o arco;

- tocar arcadas simples conectadas, em detaché;

- tocar arcadas simples separadas, em staccato.

- fazer ligaduras curtas;

- executar salto entre as cordas.

\section{1d. Conceitos teóricos}

- capacidade de afinar as notas, dada uma melodia cantada;

- tocar com senso de tonalidade;

- capacidade de repetir padrões tonais melódicos solfejando e depois tocando em pizzicato e com o arco;

- capacidade de distinguir tons agudos e graves;

- capacidade de manter a pulsação ao solfejar padrões rítmicos simples;

- capacidade de manter a pulsação tocando violino a partir de uma melodia dada;

- manter o ritmo em exercícios com pausas e contratempos.

\section{1e. Prática de conjunto}

- capacidade de permanecer dentro da pulsação rítmica do conjunto orquestral; 
- capacidade de ajustar a própria afinação com o resto do conjunto;

- demonstração de autodisciplina na cooperação por uma produção sonora melhor dentro do conjunto.

\section{1f. Expressividade musical}

- uso de variações de dinâmicas simples para ilustrar frases musicais;

- modificações timbrísticas do som por meio do uso do arco, mudando o peso, o ângulo, a velocidade e o ponto de contato;

- tocar articulações básicas correspondentes aos golpes de arco deste nível de aprendizado.

\section{Nível intermediário}

\section{2a. Postura corporal global}

- realizar movimentos unilaterais e bilaterais com o arco e o violino.

\section{2b. Mão esquerda}

- realizar extensões dos dedos da mão esquerda;

- iniciar aos movimentos da mudança de posição;

- tocar na terceira posição fixa;

- estudar harmônicos;

- realizar a substituição de dedos nos dedilhados;

- tocar cordas duplas com uso de corda solta;

- realizar escalas cromáticas.

\section{2c. Mão direita}

- desenvolvimento dos seguintes golpes de arco: detaché, martelé, staccato com ligadura;

- ligaduras longas de compasso inteiro;

- arcadas com acento;

- cordas duplas simples, com uma nota dedilhada e outra nota de corda solta;

- desenvolvimento do controle sobre as variáveis expressivas do arco, como peso, ângulo, velocidade e ponto de contato; 


\section{2d. Conceitos teóricos}

- capacidade de ajustar a afinação e escutar a ressonância dos harmônicos da nota;

- tocar de memória padrões harmônicos primários: tônica, subdominante e dominante;

- tocar padrões rítmicos com subdivisões;

- tocar padrões rítmicos com síncopas e quiálteras;

- tocar padrões rítmicos intercalados com pausas.

\section{2e. Prática de conjunto}

- capacidade de manter a pulsação ao tocar música com variação de andamentos;

- capacidade de ajustar a afinação com o conjunto;

- demonstrar compreensão do equilíbrio sonoro e musical entre a linha melódica principal e as linhas coadjuvantes;

- ter capacidade de seguir a variação de andamento sob regência;

- tocar em sincronia com as arcadas da seção de violinos de uma orquestra.

\section{2f. Expressividade musical}

- capacidade de reflexão sobre as várias maneiras de se tocar uma simples melodia;

- tocar articulações correspondentes aos golpes de arco deste nível de aprendizado.

\section{Nível avançado}

\section{3a. Postura corporal global}

- ser capaz de monitorar sua postura corporal;

- corrigir seus erros de postura e ajustar sua postura de acordo com suas características físicas pessoais.

\section{3b. Mão esquerda}

- desenvolver o vibrato inicial;

- realizar mudança da primeira posição para as posições mais avançadas, como a quinta posição; 
- tocar cordas duplas com duas notas dedilhadas;

- realizar padrões de dedilhado mais complexos.

\section{3c. Mão direita}

- desenvolver técnicas de arco detaché mais avançadas: louré, detaché lancé, portato, tremolo;

- desenvolver golpes de arco saltados: spiccato.

- realizar efeitos especiais nas várias regiões do arco: sul tasto, sul ponticello, col legno.

- executar acordes.

\section{3d. Conceitos teóricos}

- tocar de memória padrões tonais melódicos com alterações cromáticas;

- tocar de memória padrões tonais primários e secundários;

- ter a capacidade de afinar o instrumento a partir de uma nota dada;

- tocar padrões rítmicos assimétricos;

- tocar padrões rítmicos com hemíolas;

\section{3e. Prática de conjunto}

- capacidade de seguir a liderança musical do chefe de naipe dos violinos;

- tocar de acordo com o estilo musical, com dinâmica, articulação e afinação.

- prontidão na resposta à condução do maestro em padrões rítmicos mais complexos e gestos expressivos.

\section{3f. Expressividade musical}

- desenvolvimento da performance com uso de variações de dinâmica, andamento, timbrísticas e colorido musical;

- tocar articulações correspondentes aos golpes de arco deste nível de aprendizado.

- uso do vibrato para realçar o timbre e a sonoridade característica. 


\subsection{ESCOPO TÉCNICO PARA O ENSINO COLETIVO DE VIOLINO}

O escopo técnico para o ensino coletivo de violino abrange todo o conteúdo técnico musical que o aluno deve estudar enquanto participa do grupo coletivo até a conclusão do curso, quando ocorre sua passagem para as aulas individuais no formato tradicional de ensino. Esse conteúdo inicia-se desde o primeiro contato do aluno com o instrumento e com a leitura musical até o domínio das técnicas básicas do violino, a saber, todas as tonalidades da primeira posição; as mudanças de posição; o domínio da terceira posição fixa; o princípio do vibrato e golpes de arco básicos: detaché, legato, staccato, martelé e spiccato.

Delineamos o escopo técnico a partir da nossa pesquisa anterior de mestrado “O Ensino Coletivo Direcionado no Violino" - ECA-USP, 2007, por meio da comparação analítica de três métodos consagrados de ensino coletivo norte-americanos: All for Strings de G. E. Anderson \& R.S. Frost, String Builder de S. Applebaum, The Teaching of Action in String Playing de P. Rolland \& M. Mutschler. The Suzuki Concept, de S. Suzuki, também é analisado, embora não seja considerado um método de ensino coletivo tradicional.

Também fizemos inserções nesse escopo técnico a partir das nossas experiências didáticas de ensino coletivo de violino com crianças de 6 a 12 anos. Para um aprofundamento dessa análise, veja a dissertação na íntegra, Parte II, Capítulo 1 - Análise comparativa das abordagens técnicas dos principais métodos utilizados no ensino coletivo de cordas relativos ao ensino do violino, p. 53-116.

Nossa metodologia apresenta conteúdos musicais especialmente criados com a finalidade de produzir a identificação cultural da criança brasileira com seu folclore por meio do uso das melodias folclóricas do Guia Prático do Canto Orfeônico, de Heitor Villa-Lobos. Como já foi dito no capítulo 1 da presente tese, esse conteúdo programático, embora apresentado em três seções distintas, podem ser distribuídos ao longo de até três anos de curso, ou seja, o volume 1 não representa necessariamente o primeiro ano de curso, e assim sucessivamente.

Segue abaixo o escopo técnico delineado para nosso curso integral de ensino coletivo, que é composto por três seções: volume preliminar com exercícios preparatórios, volume 1 e volume 2. Ressaltamos o fato de que nesta pesquisa apresentamos apenas alguns exercícios preparatórios do volume preliminar (sem as 
fotos e ilustrações explicativas) e integralmente todo o volume 1. O volume 2 será tema de investigação posterior.

\section{Volume preliminar}

O início do volume preliminar apresenta uma breve introdução explicativa, com ilustrações e os nomes de cada uma das partes do instrumento; instruções sobre cuidados gerais e sobre o arco e acessórios, além de explicações detalhadas sobre o arco e o violino.

O aprendizado inicia-se sem a escrita musical tradicional em pentagrama, mas em um processo que utiliza a memorização. Os exercícios são realizados mecanicamente, sem levar em conta o significado da leitura musical. Simbologias não musicais, familiares ao aluno, são empregadas na realização desses estudos. É um processo de automatização, um treinamento mecânico pela memorização que é extremamente útil ao processo do aprendizado instrumental.

Exercícios de independência dos movimentos das mãos direita e esquerda são realizados desde o início do aprendizado. Essa independência de movimentos é um conceito fundamental, pois nos instrumentos de cordas cada mão executa movimentos completamente distintos. Assim, é importante estudar e dominar esses movimentos separadamente, com a atenção em uma mão de cada vez.

Os exercícios relacionados aos fatores psicomotores, a saber: tonicidade, equilibração, dominância lateral, consciência corporal, estruturação espaço-temporal, praxias global e fina, são aplicados aos exercícios musicais, para que o aluno possa exercitá-los por meio das melodias musicais.

Muito importante também é o estabelecimento correto da postura corporal e do uso do arco, que são os pré-requisitos essenciais para obtenção de boa sonoridade e afinação apurada. Uma vez que o aluno apresente tônus corporal equilibrado e sem tensões musculares impeditivas para o uso do instrumento e do arco, poderá prosseguir para a seção que inicia a leitura dos exercícios na pauta musical.

\section{Volume 1}

Neste método, para efeitos didáticos, adotamos a abordagem da semínima como unidade rítmica básica, pois encoraja a soltura do braço direito na realização dos exercícios para desenvolver a técnica do arco, conceito apoiado por todos os autores dos métodos analisados previamente: Anderson \& Frost, Samuel Applebaum 
e Paul Rolland. A única exceção é o Suzuki, que utiliza semicolcheias para trabalhar uma seção do arco.

Os conteúdos técnicos e tópicos abordados neste primeiro volume são apresentados na seguinte ordem:

a) Ritmos em mínimas e semínimas nas cordas soltas centrais, ré e lá.

b) Mudança de cordas entre ré e lá.

c) Ritmos em mínimas e semínimas nas cordas sol e ré.

d) Mudança de cordas entre as três cordas já apresentadas.

e) Síncopa na corda mi.

f) Exercícios com todas as cordas soltas.

g) Exercício em mínimas e semínimas nas quatro cordas soltas.

h) Colocação do primeiro dedo da mão esquerda na corda ré, apresentando a nota mi dedilhada.

i) Colocação do primeiro dedo na corda lá, apresentando a nota si.

j) Colocação do segundo dedo na corda ré, apresentando a nota fá\#.

k) Colocação do segundo dedo na corda lá, apresentando a nota dó\#; apresentação do sinal para retomada do arco, que neste método é representado pela vírgula acima da pauta.

I) Colocação do terceiro dedo na corda ré, apresentando a nota sol.

m) Colocação do terceiro dedo na corda lá, apresentando a nota ré dedilhada.

n) Escala de ré maior, que é feita apenas nas cordas ré e lá.

o) Escala de lá maior, feita apenas nas cordas lá e mi.

p) Exercícios nas duas escalas apresentadas.

q) Retomada de arco, que neste método é representado pela vírgula acima da pauta. Tocar em outras cordas, mantendo os dedos na corda anterior.

r) Divisão de arco.

s) Staccato.

t) Legato.

u) Posição de dedilhado para intervalos de quintas. Traços longos junto ao dedilhado representam o tempo de permanência do dedo em questão sobre a corda.

v) Combinações de velocidades de arco, sem alterações de ritmo.

w) Ligaduras de nota e de compasso. 
x) Colocação do primeiro, segundo e terceiro dedos na corda sol, apresentando respectivamente as notas lá, si e dó (leitura nas linhas suplementares).

y) Exercícios nas cordas sol, ré e lá com colocação do primeiro, segundo e terceiro dedos.

z) Colocação do quarto dedo nas quatro cordas.

aa) Colocação do primeiro, segundo e terceiro dedos na corda mi, apresentando as notas fá\#, sol e lá.

bb) Introdução ao staccato.

cc) Escala de sol maior, realizada nas quatro cordas na primeira posição.

dd) Introdução do segundo dedo baixo, posição junto ao primeiro dedo, através da tonalidade de dó maior.

\section{Volume 2}

O conteúdo técnico do segundo volume é composto por:

a) Revisão das tonalidades já trabalhadas no primeiro volume por meio de escalas e arpejos em ré maior, sol maior e dó maior.

b) Cordas duplas, por meio de intervalos de quinta, sexta, sétima, oitava, quarta, terça e segunda realizados com e sem ligaduras.

c) Conceito de legato, movimentação contínua de arco;

d) Estudo do staccato combinado com acentos musicais.

e) Colocação do primeiro dedo baixo, perto da pestana do violino, apresentando as notas láb (corda sol), mib (corda ré), sib (corda lá) e fá (corda mi).

f) Introdução do dedilhado com o terceiro dedo alto ou estendido em todas as cordas, apresentando as notas dó\# (corda sol), sol\# (corda ré), ré\# (corda lá) e lá\# (corda $m i)$.

g) Introdução do dedilhado com o quarto dedo baixo ou próximo ao terceiro dedo em todas as cordas, apresentando as notas réb (corda sol), láb (corda ré), mib (corda lá) e sib (corda $m i)$.

h) Escalas maiores e suas relativas menores: fá maior e ré menor, sib maior e sol menor.

i) Compassos compostos e quiálteras.

j) Escalas de lá maior, lá menor e ré cromática.

k) Introdução ao conceito de vibrato.

I) Uso e desenvolvimento do vibrato nos exercícios. 
m) Ritmos com semicolcheias e quiálteras, ligadas e desligadas, e desenvolvimento de várias formas de arcadas.

n) Escalas de mib maior, dó menor e mi maior.

o) Introdução da terceira posição para o violino;

p) Escala de dó maior, sol maior, ré maior e fá maior com duas oitavas e arpejos na terceira posição fixa.

q) Estudo de mudanças de posição com cada dedo separadamente.

r) Introdução da segunda posição através das tonalidades de fá maior e dó maior.

s) Estudo de trêmolo mesurado e não mesurado.

t) Spiccato.

u) Exercícios de agilidade para a mão esquerda. 


\section{MÉtOdO "ENSINO COLETIVO DE VIOLINO A PARTIR DA PSICOMOTRICIDADE"}

Os exercícios elaborados a seguir compõem o primeiro volume do método de ensino coletivo de violino, planejado para ter 150 exercícios. Eles foram compostos com base em melodias do folclore brasileiro e nos fundamentos da psicomotricidade para alunos iniciantes no aprendizado do instrumento.

Ressaltamos a importância da distribuição equilibrada entre os exercícios de caráter mais técnico e as melodias em que esses tópicos técnicos serão abordados, pois as melodias carregadas de frases com sentido musical mais evidente se fixam facilmente na memória do aluno iniciante. Desta forma, o aluno compreende rapidamente a importância dos exercícios técnicos e a sua aplicação prática nas músicas. Um método eficiente necessita apoiar-se tanto na parte técnica como na sua aplicação, que neste caso, é feita por meio das melodias ou canções.

No processo de elaboração do método utilizamos melodias folclóricas brasileiras retiradas do Guia Prático do Canto Orfeônico, primeiro volume, de Heitor Villa-Lobos. A metodologia adotada seguiu os princípios já anteriormente apresentados na dissertação de mestrado "O Ensino Coletivo Direcionado no Violino" - ECA USP, 2007, com modificações:

1) A partir da análise dos conteúdos técnicos e das propostas pedagógicas dos principais métodos de ensino coletivo de instrumentos de cordas, realizada na dissertação de mestrado "O Ensino Coletivo Direcionado no Violino" - ECA USP, 2007- parte II, estabelecemos um padrão de conteúdo técnico geral para a confecção do Método para Ensino Coletivo de Violino - volume 1.

2) Exercícios preparatórios baseados no trabalho com os fatores psicomotores foram elaborados para ser trabalhados sempre nas aulas com os exercícios do Método.

3) Foram selecionadas melodias do Guia Prático do Canto Orfeônico de Villa-Lobos, segundo critérios de dificuldade de aprendizagem considerando questões rítmicas e melódicas, saltos de intervalos musicais e tonalidades; Além disso, foram levados em consideração critérios de aprendizagem de posições de dedilhados, velocidade e postura da mão esquerda; posições e 
postura do braço direito na troca das cordas, e arcadas específicas e técnicas de arco básicas, que as melodias selecionadas proporcionam.

4) A harmonização das melodias, e seus contracantos e arranjos feitos por Villa-Lobos, foram mantidos como no original. Em alguns casos foram feitas transposições de tonalidade e alterações na métrica, sem alterar as proporções dos intervalos e nem o ritmo das melodias. Alguns ritmos foram simplificados com fins pedagógicos, isto é, para facilitar o aprendizado do aluno iniciante.

5) Além do uso das canções originais do Guia Prático, foi elaborada uma série de exercícios complementares, por meio de linhas melódicas coadjuvantes, para estimular o aprendizado e ajudar os alunos a adquirirem a técnica necessária para a execução das melodias passo a passo. Tais linhas coadjuvantes são de grande importância dentro do processo de ensino, pois ao realizar estas linhas melódicas mais simples, o aluno tem sua percepção aguçada em relação à melodia principal. Elas receberam o mesmo nome da melodia original, mas com numerações diferentes e foram elaborados de maneira que todos possam ser tocados ao mesmo tempo, por grupos de alunos em diferentes estágios de aprendizagem. Para o aluno que está estudando uma dessas lições pela primeira vez em classe, o professor tem condições de tornar bem mais interessante o aprendizado de um exercício simples de cordas soltas; basta acompanhar o exercício com a linha melódica original no violino ou em algum outro instrumento de acompanhamento harmônico, como o piano. Dessa forma, desenvolve-se o ouvido harmônico do aluno, assim como noções de música de câmara, pois desde o início já se estimula o ouvido a escutar várias linhas melódicas tocadas ao mesmo tempo.

Outra possibilidade de utilização dos múltiplos exercícios que acompanham uma mesma melodia é a realização de ensaios com grupos de alunos em diferentes estágios de aprendizado, principalmente para apresentações em audições de alunos, de encerramento de atividades das classes ou em comemorações especiais.

Reunir alunos de diferentes estágios de aprendizado para tocar juntos, geralmente é muito positivo para todos. Os iniciantes se inspiram e se animam a 
estudar mais para tocar tanto quanto os mais avançados, pois veem os outros, que têm idade próxima à sua, como modelos possíveis de serem alcançados. Além disso, essa prática desperta o desejo de estudar para tocar linhas melódicas mais interessantes e complexas. Os alunos mais adiantados, por sua vez desempenham função importante, sendo despertados para o senso de responsabilidade e cuidado para com o grupo, pois precisam tocar sua linha melódica da maneira mais perfeita possível, com boa afinação, ritmo e fraseados musicais indicados, além de boa sonoridade. Trabalha-se dessa forma o espírito de liderança musical e também a escuta camerística, na medida em que precisam tocar ouvindo todas as outras linhas melódicas coadjuvantes.

Além disso, os alunos mais adiantados aprendem com a detecção de erros dos outros; ao enxergar o erro na outra pessoa, o próprio aluno aprende a não repeti-lo. Muitas vezes, instintivamente os mais adiantados atuam como "monitores" dos alunos iniciantes, ajudando-os na correção da postura, nos problemas de afinação, nas dificuldades de leitura musical, entre outros. Tudo isso acontece de forma espontânea na dinâmica de grupo, e tanto os alunos iniciantes como os avançados são beneficiados.

As melodias originais do Guia Prático em que se baseou a elaboração dos 150 exercícios do volume 1, que podem lhes servir de acompanhamento, estão identificadas na descrição antes do título de cada uma. As melodias originais tal como se apresentam no Guia Prático foram identificadas nos respectivos títulos. Os exercícios são apresentados por ordem de dificuldade progressiva, sendo que cada um deles propõe ao aluno uma nova técnica a ser aprendida.

Os exercícios iniciais do método foram elaborados utilizando leitura em mínimas nas duas cordas centrais do violino e o controle da técnica de arco para que ele possa obter uma boa sonoridade do instrumento, dominando o ângulo da passagem do arco sobre a segunda e terceira cordas (respectivamente as cordas lá e ré), na região da curvatura central do cavalete. Tal opção metodológica tem como objetivo o controle e o domínio do arco em primeiro lugar, para mais tarde, progressivamente, acrescentar dificuldades para a mão esquerda. Essa escolha encontra ressonância nas propostas dos consagrados métodos All for Strings e String Builder.

Ao iniciar o aprendizado pelas cordas centrais do instrumento, também estaremos trabalhando com as cordas que são comuns aos outros instrumentos de 
cordas, pois assim logo de início todos os instrumentos podem tocar juntos. 0 método pode ser futuramente ampliado para viola, violoncelo e contrabaixo.

Ao trabalhar na região central do cavalete, o aluno vai se acostumando a controlar sua curvatura, ao usar o braço direito no arco. E ao adquirir controle do arco sobre as duas cordas centrais, o aluno tem mais facilidade para tocar nas cordas periféricas do cavalete (sole $m i)$.

Apenas para comparar este Método com métodos que apresentam uma abordagem diferente, citamos o método Suzuki, que é conhecido por ser utilizado para iniciar crianças ao violino. Esse método opta por iniciar o aprendizado pelas duas primeiras cordas do violino, as cordas mi e lá, buscando facilitar o contato do aluno iniciante com o instrumento. Isso considerando que é mais fácil para o aluno iniciante tocar na primeira corda $(m i)$, uma vez que o braço direito do arco está posicionado mais próximo ao corpo, não exigindo maior esforço para erguê-lo para tocar na quarta corda (sol). Ao mesmo tempo em que essa escolha facilita o aprendizado, pois não tem outra corda antes da primeira $(m i)$ e permite maior liberdade de movimentos do braço direito, já que, a esta altura, o iniciante ainda não controla bem seus movimentos. A relativa simplificação do aprendizado da mão direita no método Suzuki, vem acompanhada de uma dificuldade maior no aprendizado para a mão esquerda, pois logo de início, a primeira música do método para violino, já propõe a colocação dos três dedos da mão esquerda em duas cordas do instrumento. O método Suzuki focaliza sua atenção nos movimentos da mão esquerda no início do aprendizado do instrumento, tornando relativamente mais fácil o trabalho da mão direita com o arco.

Nossa opção metodológica foi ensinar a colocação dos dedos nas cordas ré e lá paulatinamente, por meio de exercícios progressivos. Como já foi dito, essa escolha se assemelha à dos métodos All for Strings e String Builder, cujas primeiras lições dos primeiros volumes são bastante similares; ambas iniciam-se pelas cordas centrais, ré e lá, introduzindo posteriormente as cordas sol e mi. Ao apresentarem a colocação dos dedos da mão esquerda, também utilizam a mesma ordem do começo do método. A diferença é que o All for Strings apresenta os três dedos em uma só corda primeiramente, a corda ré, para depois passar para a colocação dos dedos nas cordas lá, sol e mi. No String Builder, a colocação dos três dedos é apresentada simultaneamente nas cordas ré e lá, para depois ser apresentada nas cordas sol e mi. 
Escolhemos iniciar o método seguindo abordagens como as de Paul Rolland, que encoraja a soltura do braço direito na realização dos exercícios com o uso de figuras musicais de andamento mais rápido como as mínimas e semínimas. Esse conceito também encontra apoio entre autores dos métodos norte americanos Anderson \& Frost e Samuel Applebaum.

Pela ordem do ensino da teoria musical, seria natural iniciar pelo ensino da semibreve. Porém, para o aluno iniciante que ainda não tem o devido controle motor e não domina a movimentação do braço, é mais difícil controlar o arco em notas longas por muito tempo, fator que dificulta o aprendizado em uma turma de crianças de seis anos, que é a idade que consideramos ideal para iniciar o aprendizado em turmas coletivas, por exemplo. Através de figuras rítmicas de duração menor como as mínimas e semínimas, o aluno adquire mais facilidade para desenvolver e direcionar seu senso rítmico nos exercícios e para relaxar as suas tensões estáticas como afirmou Paul Rolland, obtendo um tônus equilibrado e flexibilidade nos movimentos.

O método foi dividido em seções de conteúdo técnico, denominadas lições. No primeiro volume, foram planejadas 14 lições, sendo que cada lição contém dez exercícios, com exceção da primeira lição que contém 19 exercícios em cordas soltas e da última que contém 11 exercícios. Desse modo temos a seguinte divisão:

- Lição 1 - exercícios de 1 a 19;

- Lição 2 - exercícios de 20 a 29;

- Lição 3 - exercícios de 30 a 39;

- Lição 4 - exercícios de 40 a 49;

- Lição 5 - exercícios de 50 a 59;

- Lição 6 - exercícios de 60 a 69;

- Lição 7 - exercícios de 70 a 79;

- Lição 8 - exercícios de 80 a 89;

- Lição 9 - exercícios de 90 a 99;

- Lição 10 - exercícios de 100 a 109;

- Lição 11 - exercícios de 110 a 119;

- Lição 12 - exercícios de 120 a 129;

- Lição 13 - exercícios de 130 a 139;

- Lição 14 - exercícios de 140 a 150. 
É preciso ressaltar a necessidade de se realizar os exercícios preparatórios para o aprendizado do violino nas primeiras semanas de curso, mesmo antes de o aluno pôr as mãos no instrumento. Posteriormente, a cada início de aula, esses exercícios serão refeitos e aprimorados com novos níveis de dificuldade, com a finalidade de desenvolver os fatores psicomotores implícitos em cada movimento exigido pelo conteúdo técnico.

Segue-se uma análise dos conteúdos técnicos de cada lição e seus exercícios.

\section{Lição 1}

Antes de iniciar toda e qualquer aula, o professor deve realizar exercícios preparatórios com a classe com a finalidade de preparar a musculatura dos alunos e regular seu tônus corporal. Os exercícios preparatórios estão descritos no capítulo III - "Exercícios preparatórios baseados em princípios psicomotores para o aprendizado no violino".

A lição 1 é composta por 19 exercícios. Segue abaixo uma descrição técnica dos exercícios e recomendações de seu uso:

- Todos os exercícios desta primeira lição trabalham as cordas soltas através das figuras rítmicas da mínima e semínima.

- Antes de tocar qualquer exercício, o solfejo rítmico e melódico deve ser executado em todas as linhas do exercício. Somente após obter um resultado satisfatório com o solfejo e leitura musical é que deve tocar no instrumento.

- A maior parte dos exercícios se apresenta em duas linhas melódicas idênticas, pois foram elaborados para ser tocados pelo aluno com pizzicato na primeira linha e depois com o arco na segunda linha. Lembramos que entre a primeira e a segunda linhas do exercício há uma parada, representada pela fermata na pausa, que deve durar o tempo necessário e suficiente para que todos os alunos verifiquem sua própria postura corporal e a posição no violino e no arco, como aparece nos exercícios de 1 a 5, 7, 11, 12, 15, 16.

- Os exercícios de 1 a 3 são feitos com pizzicato de mão direita que aparecem na pauta apenas como pizz., sem outras indicações. Esses exercícios têm a função de acostumar o aluno a tocar o pizzicato com a mão direita: com o polegar direito apoiado no canto do espelho do violino próximo à primeira corda e tocar beliscando a corda com a polpa do dedo indicador a cerca de 1,5 
$\mathrm{cm}$ em cima do espelho, buscando a produção de uma boa sonoridade, de timbre mais suave e com boa projeção, evitando tocar com a ponta do dedo e unhas, para não produzir um som metálico. Além disso, esses exercícios iniciam a leitura na pauta, e o aprendizado de tocar nas duas cordas centrais do violino ré e lá.

- Durante a lição 1, o pizzicato de mão direita será marcado com o dedilhado do número zero (0), indicando a corda solta e diferenciando-o do pizzicato de mão esquerda, que será marcado com o dedilhado de número quatro (4) com o sinal de (+) em cima, indicando o uso do dedo mínimo da mão esquerda para beliscar a corda, e não o uso do quarto dedo pressionando a corda.

- A partir do exercício 4, apresenta-se ao aluno o pizzicato de mão esquerda marcado com o sinal (+) acima das notas junto com a indicação do uso do quarto dedo (dedo mínimo) da mão esquerda. Esse uso do pizzicato de mão esquerda, nesse momento do método, tem a função de aproximar a palma da mão do aluno ao espelho do violino, para manter a forma dos quatro dedos próximos às cordas. Dessa forma, o aluno pode manter a forma da mão sem ter de se preocupar ainda com a afinação por meio do uso efetivo desse dedo, pois no pizzicato, ele pode ser realizado em qualquer lugar da corda, sem a necessidade de prender a corda com o quarto dedo em alguma altura específica.

A escolha por essa forma de uso do quarto dedo é feita por causa das experiências com turmas de crianças de 6 anos em projetos sociais, pois muitas vezes elas são provenientes de situações de risco social e, portanto foram pouco estimuladas quando pequenas e apresentam dificuldades maiores do que a média de sua idade nas questões de controle psicomotor e nos aspectos cognitivos. Costumam apresentar grande dificuldade na compreensão do movimento necessário, na distinção e na dissociação dos movimentos de cada dedo requisitado pelo exercício musical. Por isso essa forma de usar o quarto dedo foi planejada para que o aluno tenha consciência dele e de seu uso, ao mesmo tempo sem exigir ainda um controle motor fino desse movimento que no início do aprendizado ele ainda não domina.

O exercício 1 apresenta os sinais musicais, como clave de sol, fermata, indicação de fórmula de compasso quaternário simples e barra de repetição final, assim como as figuras musicais de mínima, semínima e pausa de mínima. Outro elemento apresentado é a contagem dos compassos. É importante ressaltar aqui, 
que a marcação do número dos compassos (sempre em cima ou próxima à barra de compasso) não deve ser confundida com dedilhado (marcado sempre acima ou abaixo da nota).

Também há indicação de pizzicato e de sinais de arcadas para baixo (direção do talão para ponta) e para cima (direção da ponta para talão), escritos respectivamente sobre as duas primeiras notas da segunda linha do exercício. A primeira nota apresentada é o ré, a ser tocada na terceira corda do violino.

\section{Corda Re - Pizzicato e arco}

Tocar pizzicato na primeira linha e parar na fermata o tempo suficiente para verificar se a posição do arco está correta antes de tocar na segunda linha.
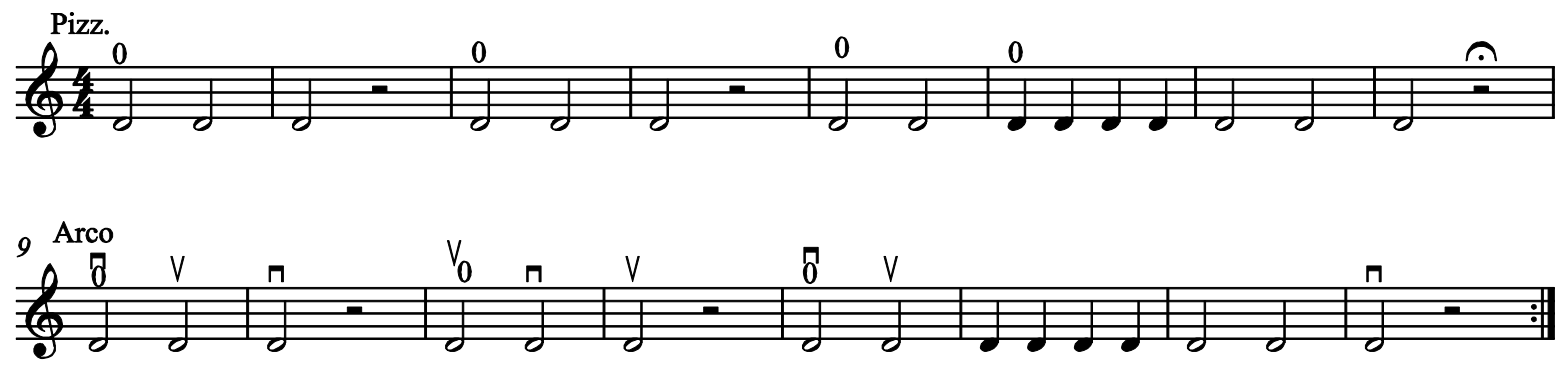

O exercício 2 apresenta a segunda corda do violino, a corda lá.

\section{Corda La - Pizzicato e arco}

Parar na fermata o tempo suficiente para verificar se a posição do arco está correta.
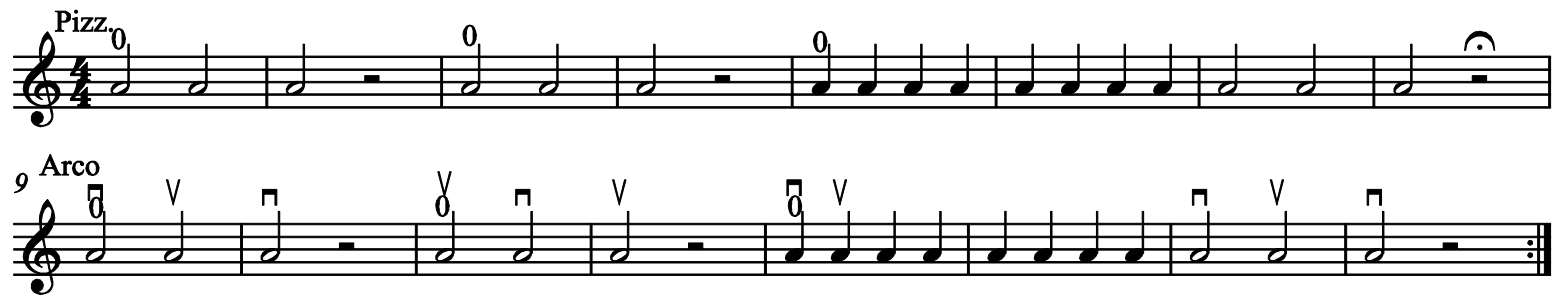

O exercício 3 desenvolve o estudo com as cordas ré elá.

\section{Cordas Re e La - Pizzicato e arco}

Parar na fermata o tempo suficiente para verificar se o arco está na posição correta.
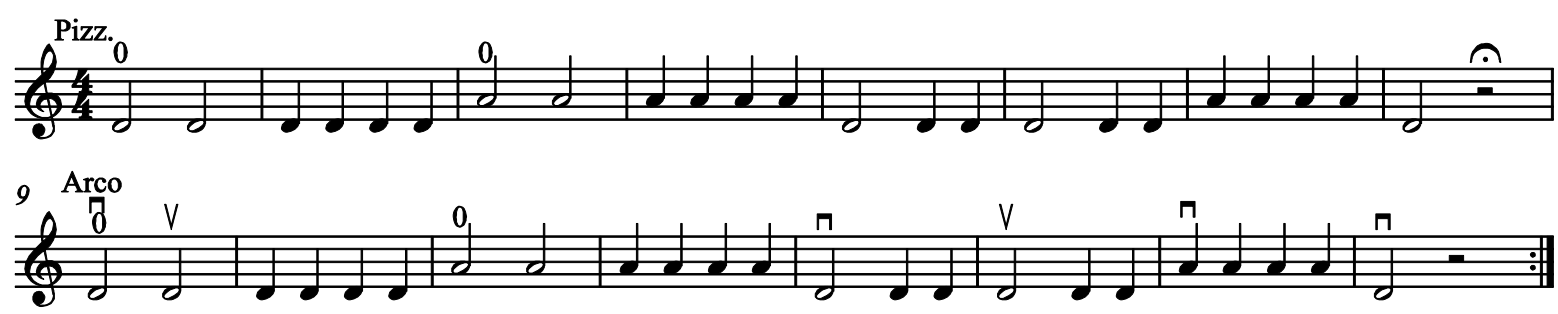
O exercício 4 apresenta o pizzicato de mão esquerda, a ser realizado com o dedo mínimo da mão esquerda, e também o pizzicato de mão direita, fazendo uso dos dois tipos de pizzicato.

\section{Pizzicato de mão direita e esquerda}

\section{Exercício com pizzicato de mão direita (0) e mão esquerda (4/+). \\ Parar na fermata o tempo suficiente para verificar se a postura do arco está correta.}

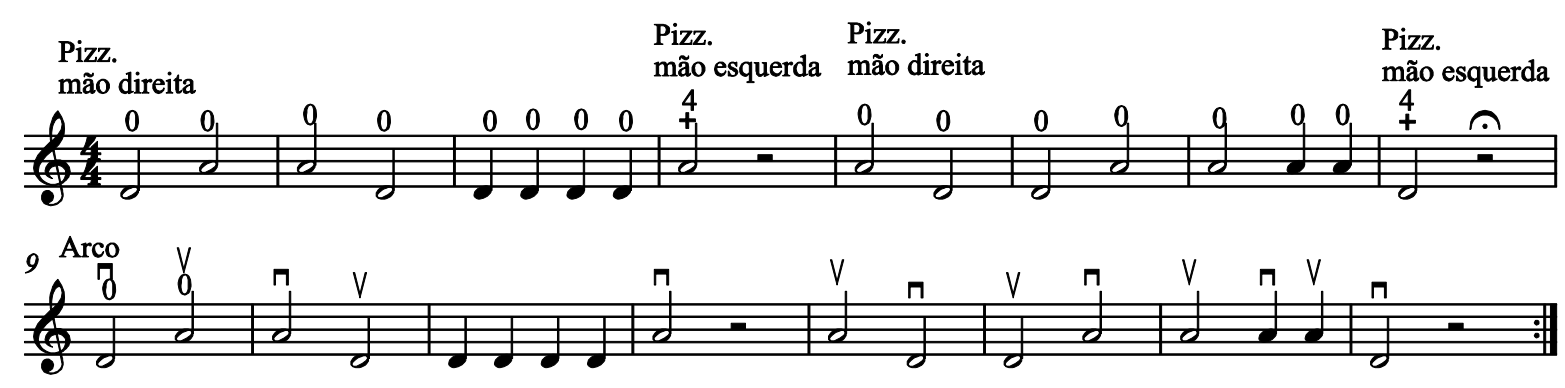

O exercício 5 apresenta a pausa de semínima, ao mesmo tempo em que desenvolve todos os elementos técnicos anteriores, pizzicato de mão direita, pizzicato de mão esquerda e arco.

\section{Pizzicato mão direita, mão esquerda e arco}

Sempre parar na fermata o tempo suficiente para verificar se a postura do arco está correta.
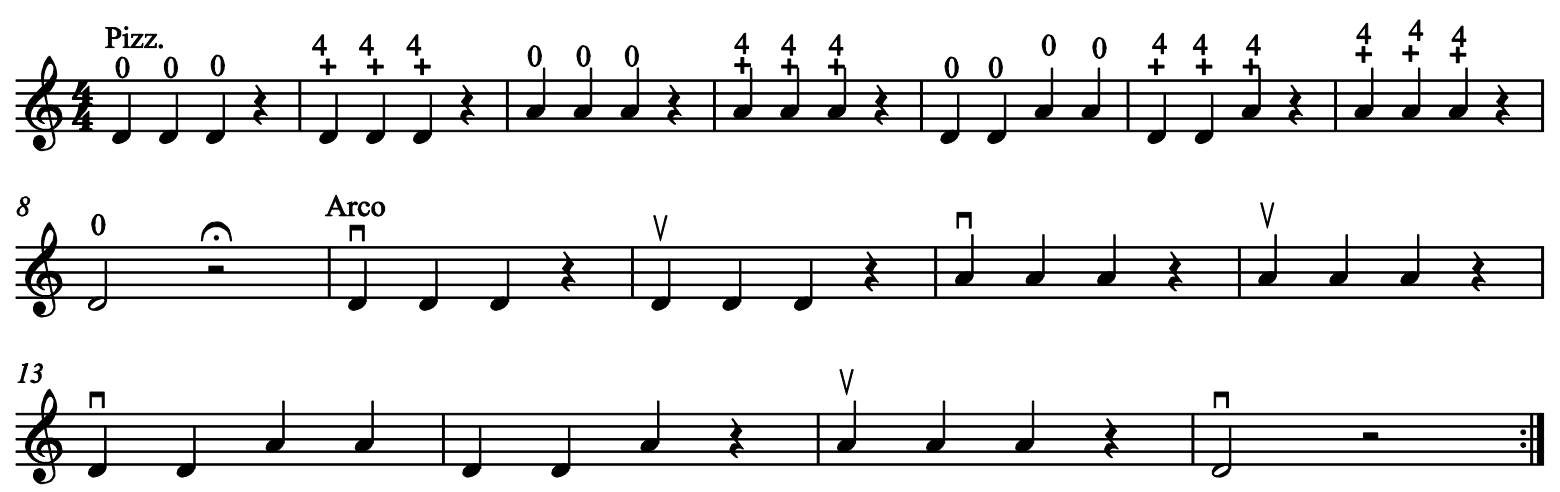

O exercício 6 é o primeiro exercício que apresenta o uso de uma canção folclórica brasileira, o "Cai, cai balão". Ele está intitulado "Cai, cai balão1" pois indica que se trata da primeira linha melódica coadjuvante, que serve de acompanhamento simplificado para essa melodia. No decorrer do método surgirão outros exercícios sobre a mesma melodia do "Cai, cai balão", porém cada vez com um número 
diferente. O número crescente do título sugere o aumento do grau de dificuldade técnica para o aluno.

Logo depois do exercício 6, segue o exercício "6a", que é idêntico ao exercício anterior acrescido da linha do professor abaixo da linha do aluno. Dessa forma o método sempre apresentará primeiro a versão da linha do aluno, e em seguida, apresentará o próximo exercício com o mesmo número acrescido da letra "a" minúsculo, indicando que é o mesmo exercício anterior acrescido da linha do professor. A opção metodológica por apresentar primeiramente o exercício 6 somente com a linha do aluno para logo depois apresentar "6a" com a linha do professor segue a lógica do aprendizado psicomotor do cérebro humano, que é capaz de realizar várias tarefas diferentes ao mesmo tempo, porém aprende uma novidade de cada vez. Por isso, o aluno aprende o exercício com a linha do aluno e suas dificuldades inerentes em primeiro lugar. Assim que dominar estas novidades, irá ler novamente a mesma linha melódica, junto com a apresentação de um elemento novo na leitura que é o acréscimo da linha do professor.

Já desde o início, o conceito de anacruse, muito comum nas canções folclóricas brasileiras, é apresentado ao aluno em forma de pausa de semínima no exercício 6. É interessante que se apresente logo em seguida o exercício "6a" no qual acontece de uma nota ser tocada na anacruse da linha do professor, enquanto o aluno tem pausa. Dessa forma o entendimento do aluno sobre a função de sua pausa em anacruse é facilitado.

\section{Cai, cai balão 1}
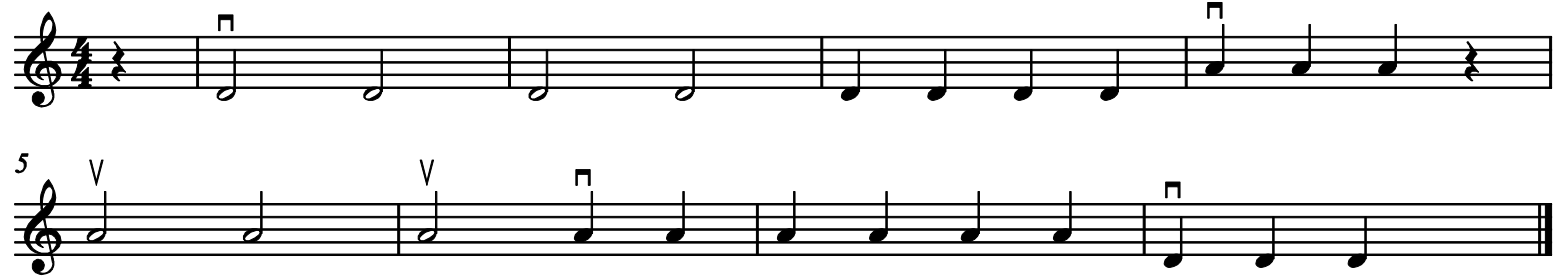
No exercício "6a" apresentamos a armação de clave para tonalidade de ré maior, com a linha do professor escrita logo abaixo da linha do aluno.

\section{6a. Cai, cai balão 1a}
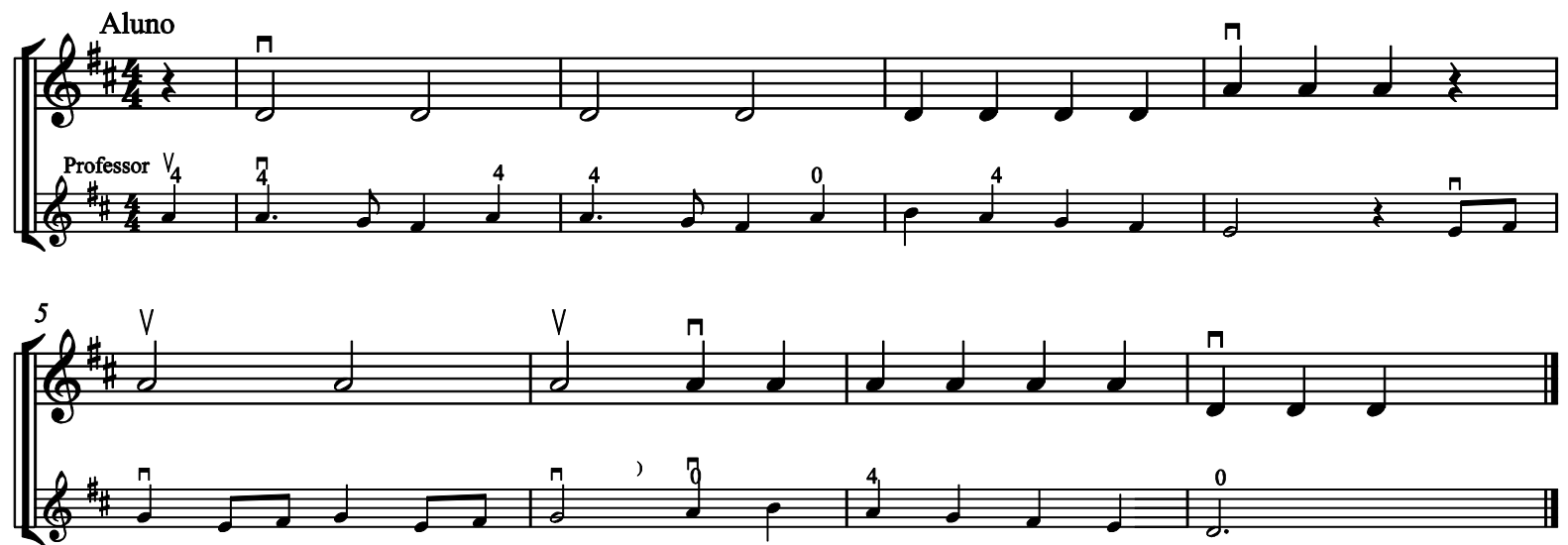

O exercício 7 apresenta a quarta corda do violino, a corda sol, além de exercitar as arcadas, e os pizzicatos de mão direita e esquerda.

\section{Corda Sol}

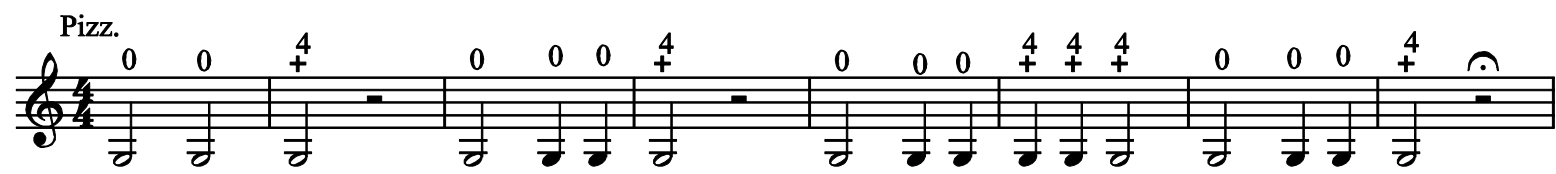

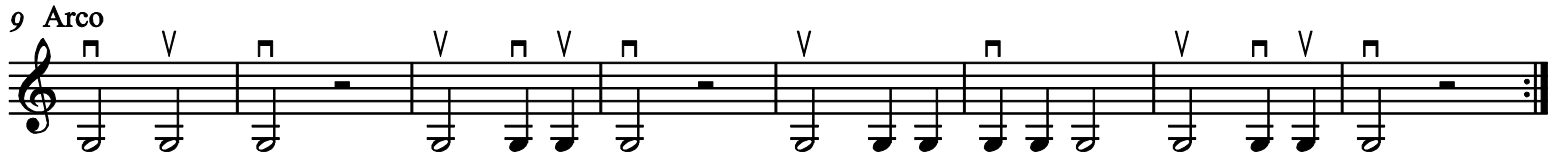

O exercício 8 apresenta a primeira linha melódica coadjuvante para a canção folclórica Bambalalão. As cordas tocadas serão a terceira (ré) e quarta cordas (sol).

\section{Bambalalão 1}

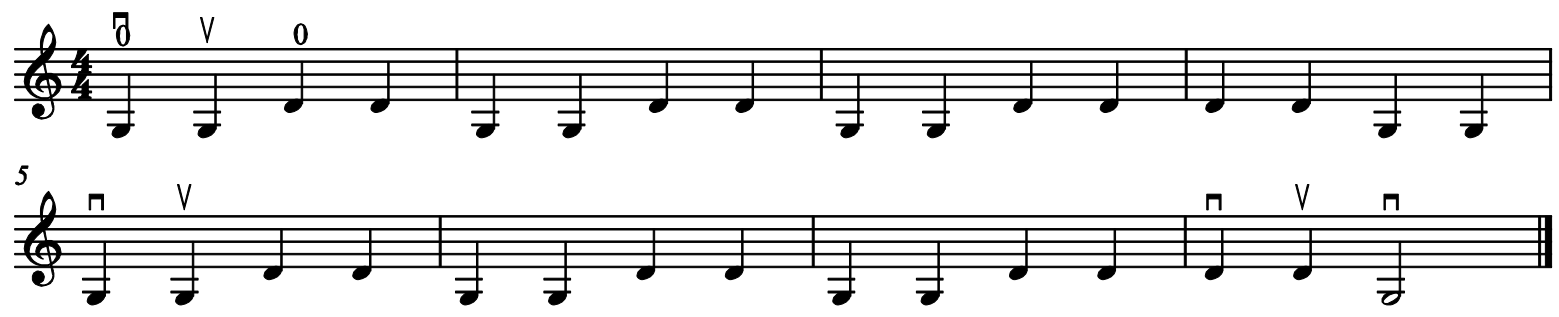


O exercício seguinte é o mesmo que o anterior acrescido da linha do professor. Neste exercício "8a" apresentamos a armadura de clave para a tonalidade de sol maior.

\section{8a. Bambalalão 1a}
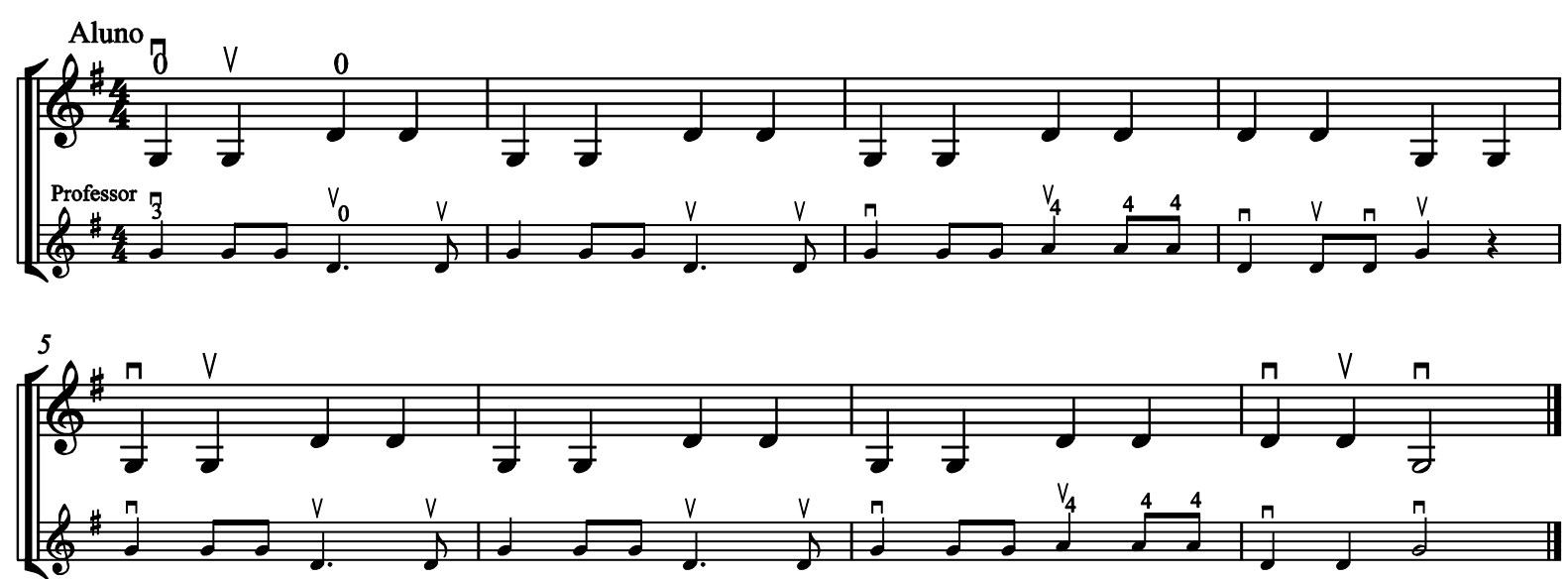

O exercício 9 apresenta a primeira linha melódica coadjuvante para a canção folclórica Ó ciranda, ó cirandinha, com as cordas ré e sol.

\section{9. Ó Ciranda, ó cirandinha 1}

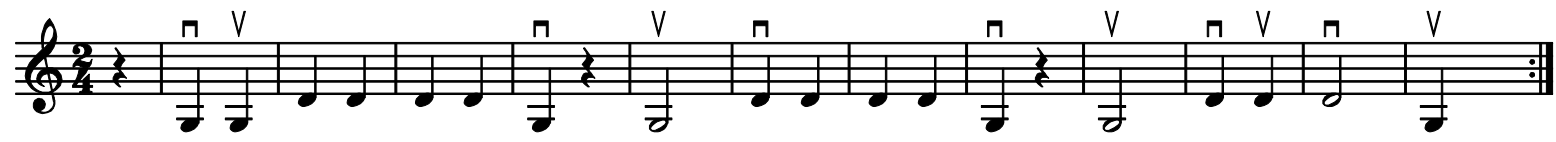

O exercício seguinte é o mesmo que o anterior, acrescido da linha do professor. A tonalidade apresentada é de sol maior. Iniciamos a linha do professor com levare de apenas uma colcheia, diferente da melodia original do Guia Prático, pois é a forma como popularmente se canta.

9a. Ó ciranda, ó cirandinha 1a
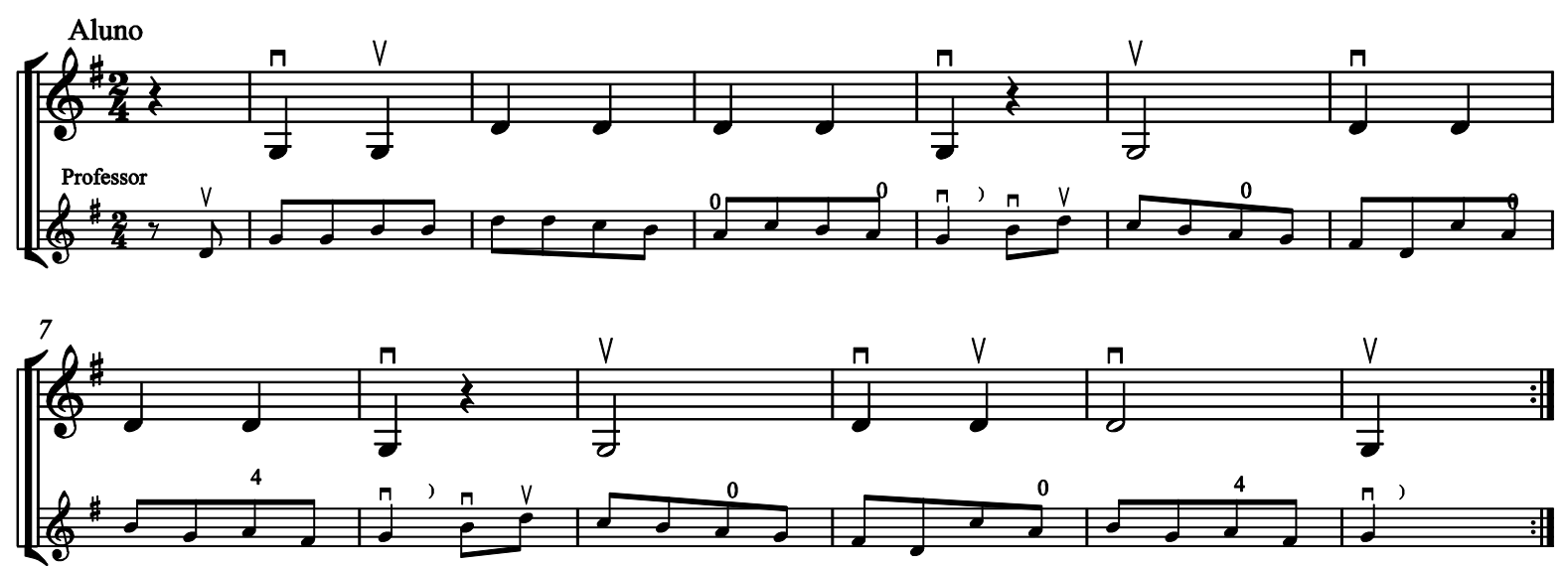
O exercício 10 apresenta a primeira linha melódica coadjuvante para a canção folclórica Passe, passe gavião.

10. Passe, passe gavião 1
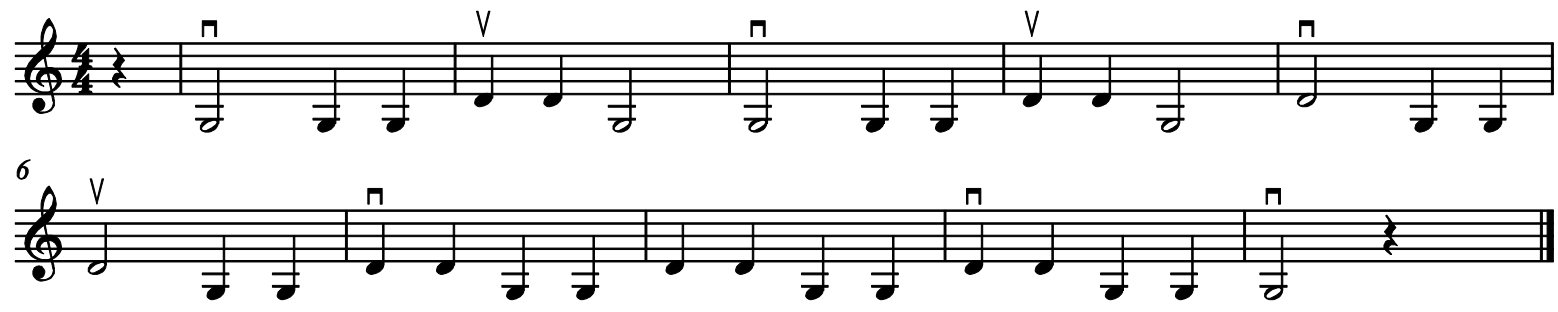

O exercício seguinte é o mesmo que o anterior acrescido da linha do professor.

10a. Passe, passe gavião 1a
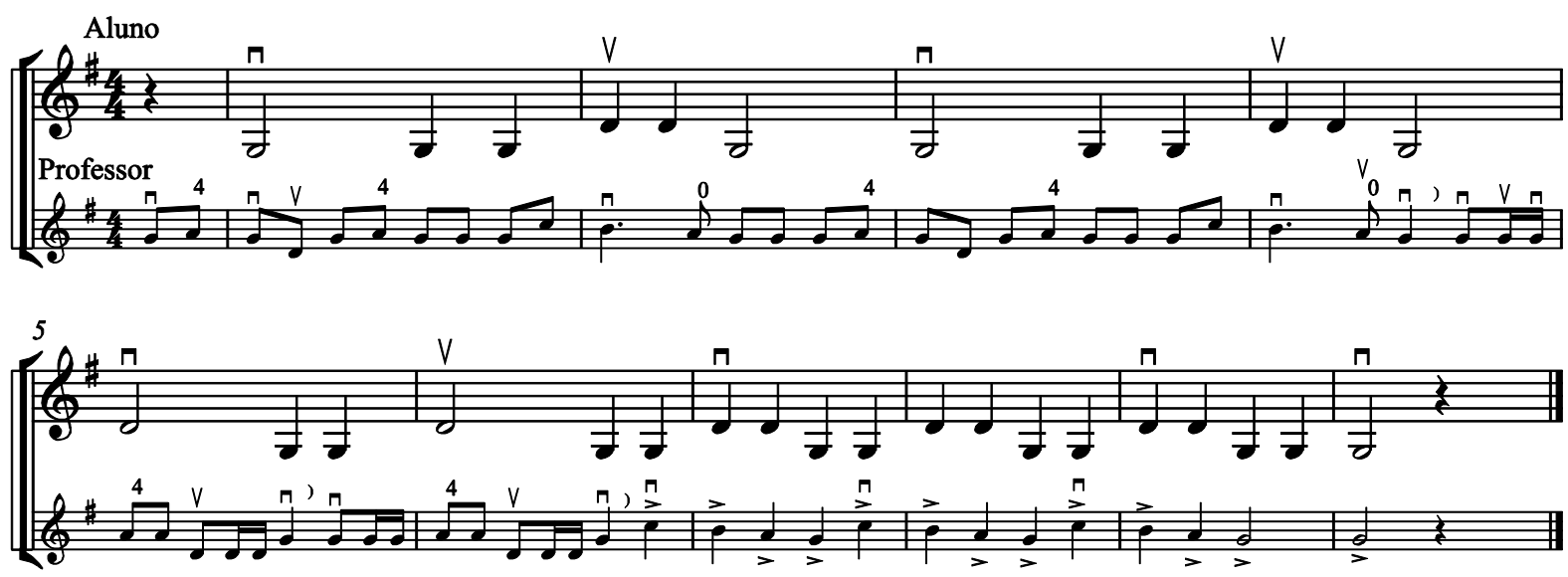

O exercício 11 apresenta a fórmula de compasso ternária simples, nas cordas ré e sol.

11.
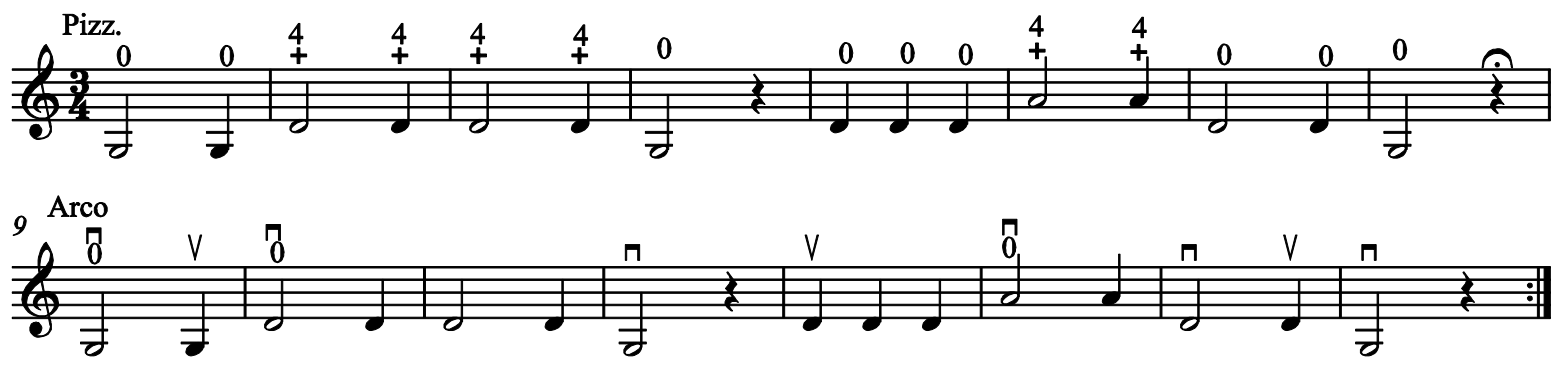
O exercício 12 apresenta pizzicato de mão direita e esquerda, e uso de arco em três cordas, a saber, lá, ré e sol.

12.

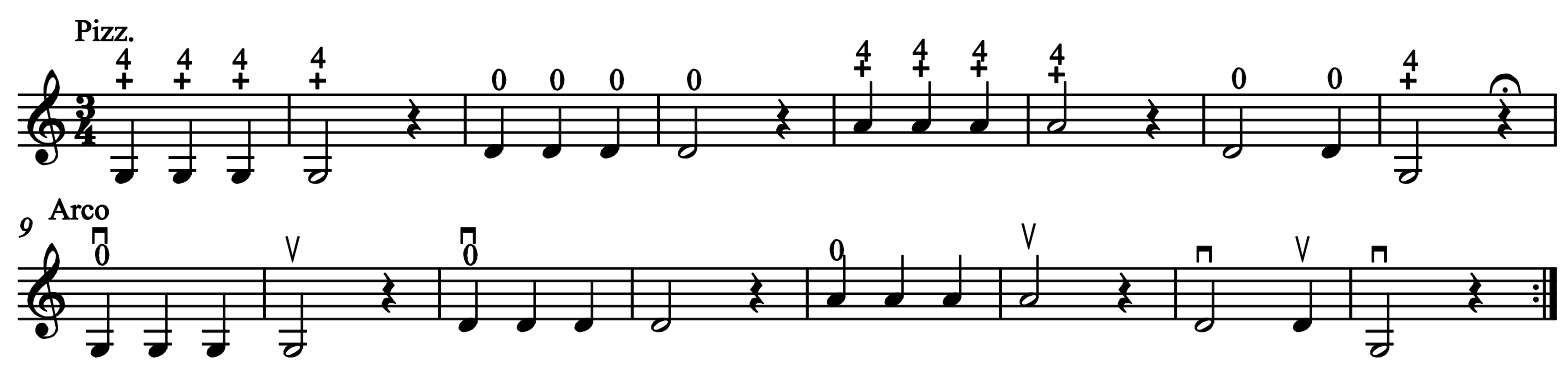

O exercício 13 apresenta a primeira linha melódica coadjuvante para a canção folclórica $O$ cravo brigou com a rosa. A fórmula de compasso é ternária simples, com uso de três cordas, lá, ré e sol.

\section{0 cravo brigou com a rosa 1}

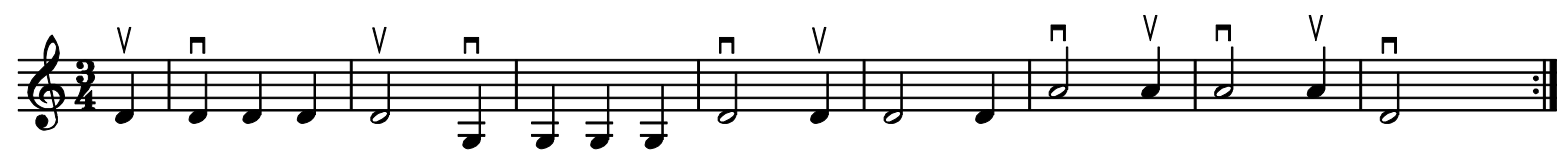

O exercício seguinte é o mesmo que o anterior acrescido da linha do professor. A tonalidade apresentada é de ré maior.

\section{3a. 0 cravo brigou com a rosa 1 a}

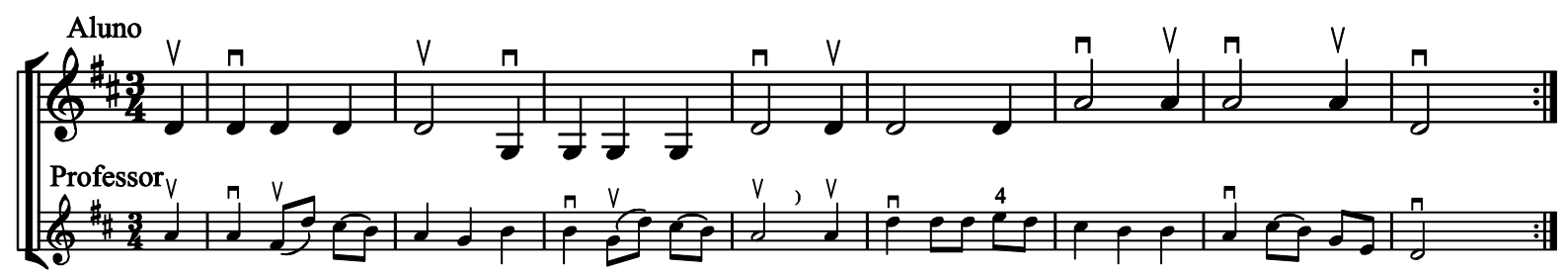

O exercício 14 apresenta a segunda linha melódica coadjuvante para a canção folclórica Cai, cai balão. O elemento técnico novo é o salto entre as três cordas anteriormente trabalhadas, a saber, lá, ré e sol. Este exercício pode ser executado junto com a primeira linha coadjuvante, representada no exercício 6 , além da melodia original apresentada mais adiante no exercício 99. 
Para este exercício, é necessário estudar primeiramente com os alunos o domínio angular do arco sobre cada corda, por meio dos exercícios silenciosos de mudanças de cordas descritos no exercício preparatório 34 do capítulo 3.2.1 O arco da presente tese.

O aluno deve aproveitar a pausa de semínima para preparar o movimento da mudança de corda.

\section{Cai, cai balão 2 - salto de cordas}

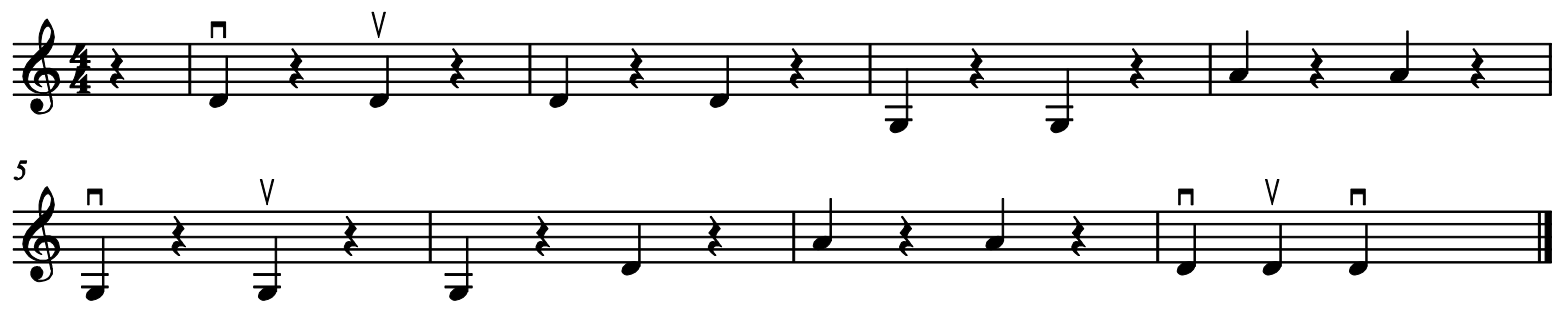

O exercício seguinte é o mesmo que o anterior acrescido da linha do professor. A tonalidade apresentada é de ré maior.

\section{4a. Cai, cai balão $2 a$}
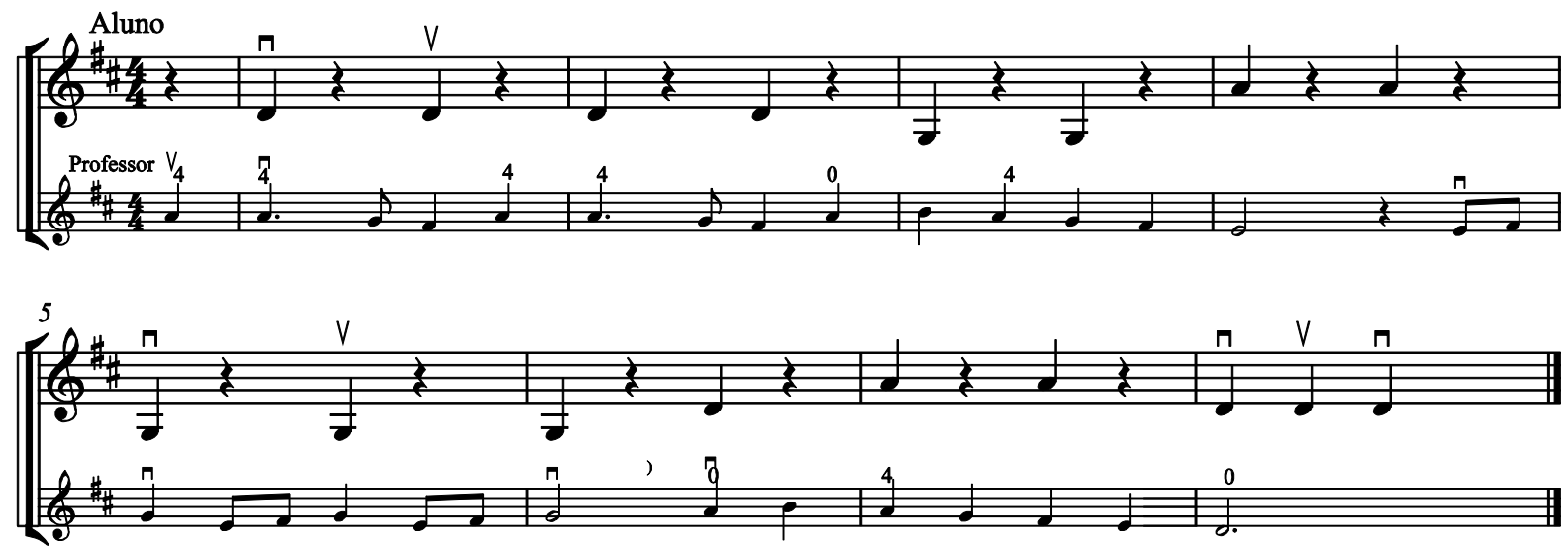
O exercício 15 apresenta um novo elemento rítmico musical, que é a síncopa, muito comum na música brasileira. Além disso, apresenta também a primeira corda do violino, a corda mi.

\section{Corda Mi - síncopas}

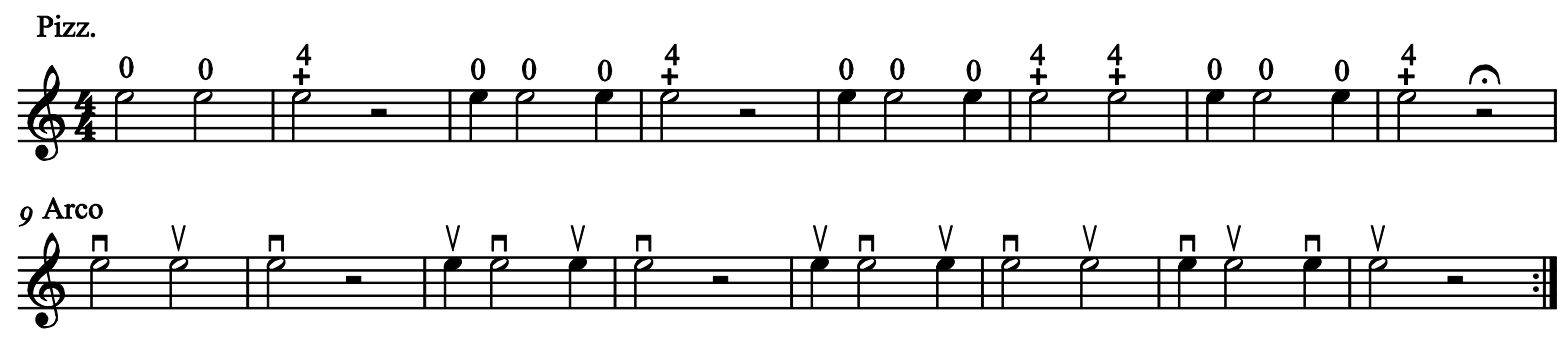

O exercício 16 apresenta o estudo nas cordas mi e lá, desenvolvendo o ritmo das síncopas aprendido anteriormente.

\section{Síncopas nas cordas La e Mi}

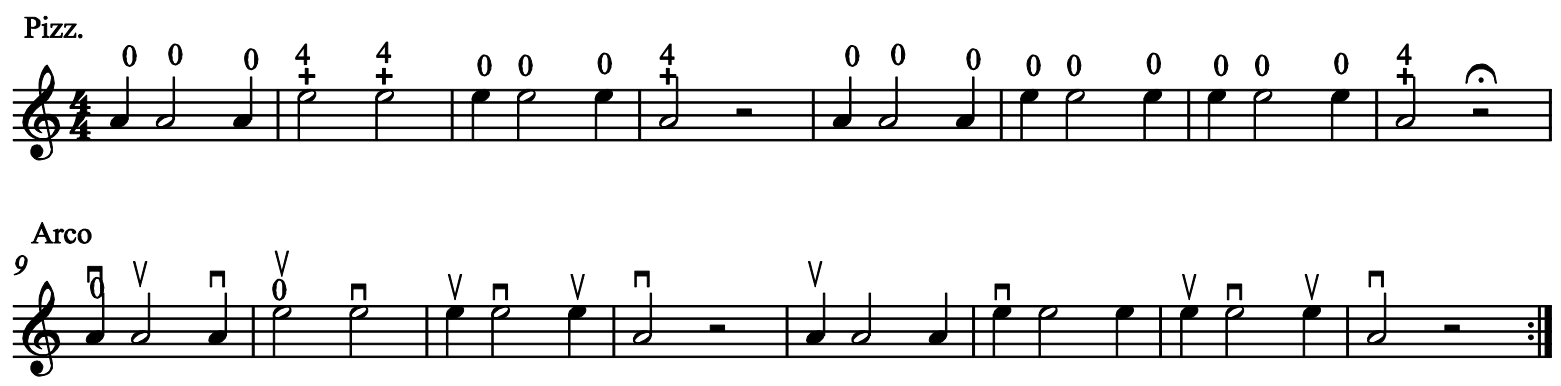

O exercício 17 apresenta a primeira linha melódica coadjuvante para a canção folclórica Caranguejo. Este exercício desenvolve a mudança das quatro cordas, que deve ser exercitada através dos exercícios preparatórios, semelhante ao exercício 14.

\section{Caranguejo 1}
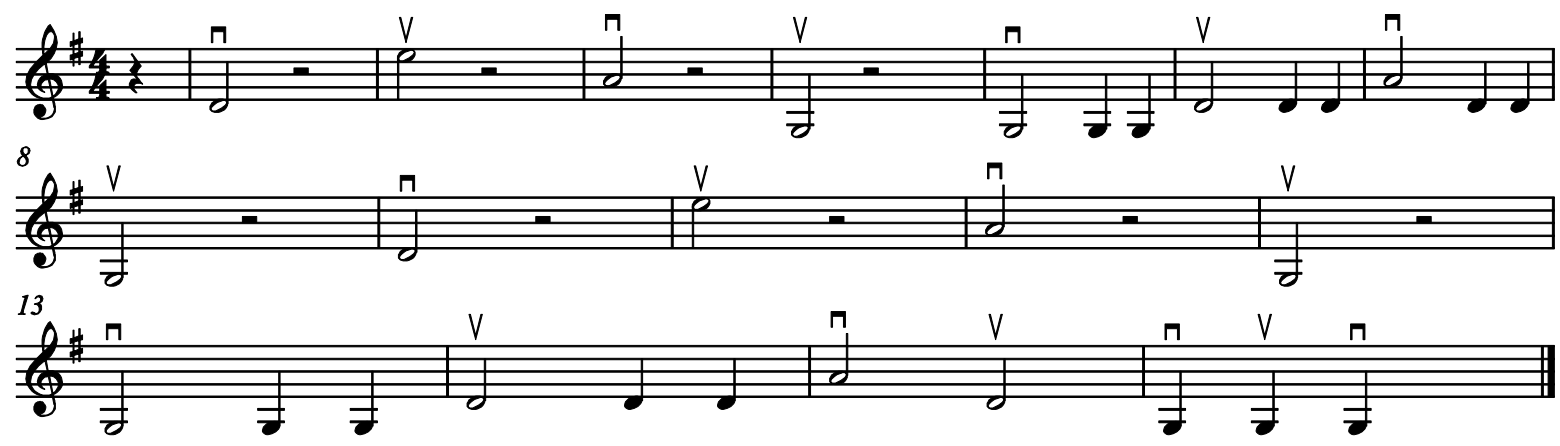
O exercício seguinte é o mesmo que o anterior, acrescido da linha do professor. A tonalidade apresentada é de sol maior.

\section{7a. Caranguejo 1a}
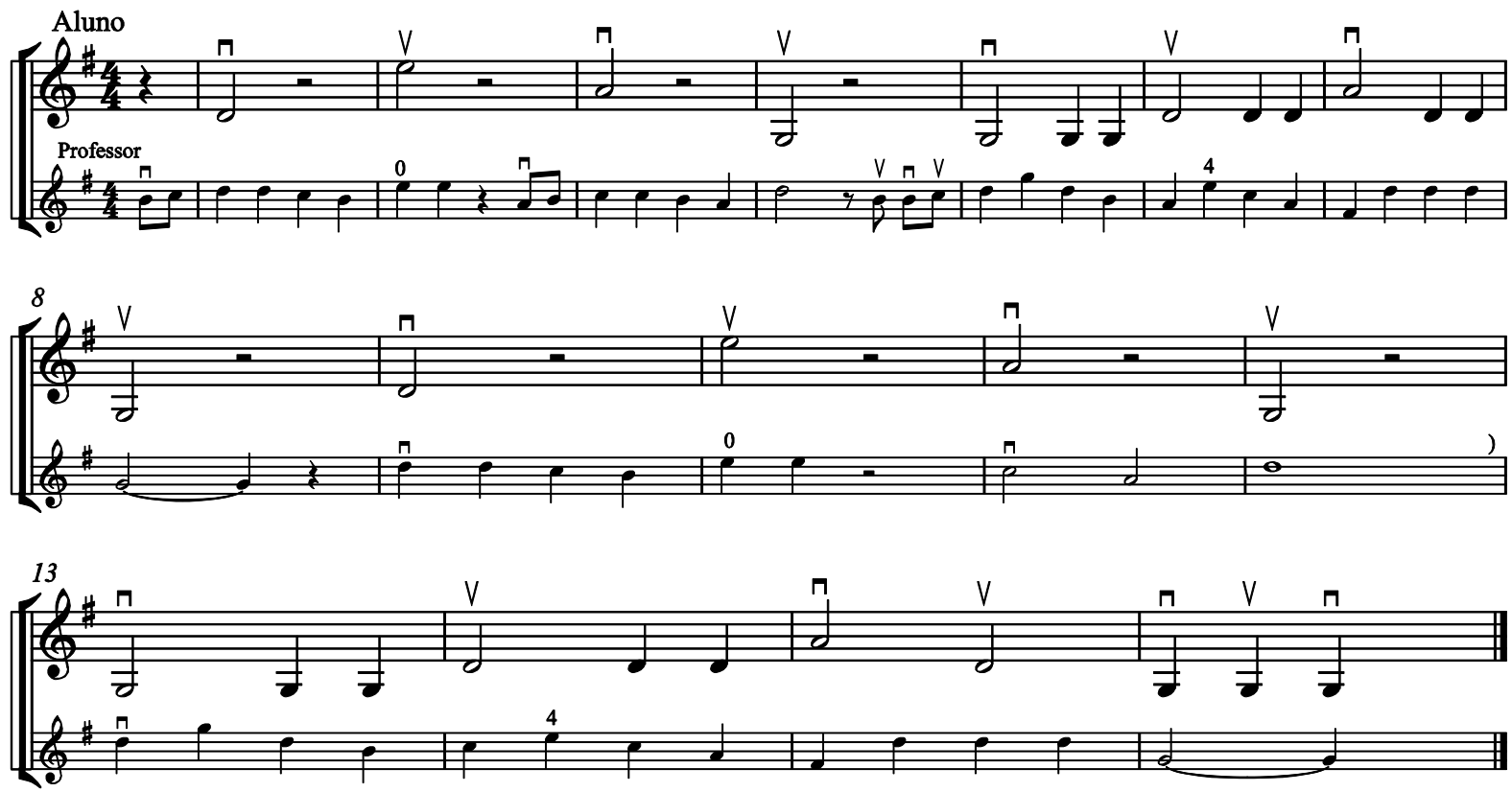

O exercício 18 é a primeira linha melódica coadjuvante para a canção folclórica $A$ canoa virou. Apresenta um novo elemento técnico, que é a retomada de arco. Para este exercício, é necessário desenvolver previamente o movimento da retomada de arco e o controle na partida e chegada do arco na corda, por meio do exercício preparatório 33 no capítulo 3.2.1 O arco da presente tese.

\section{A canoa virou 1 - retomada de arco}

Apresentamos a retomada de arco através do sinal ) que está no último compasso.

A mão direita deve continuar o movimento descendente descrevendo um semicírculo

e recolocar o arco suavemente no talão antes de tocar. Tomar o cuidado de pousar o arco na corda antes de tocar.
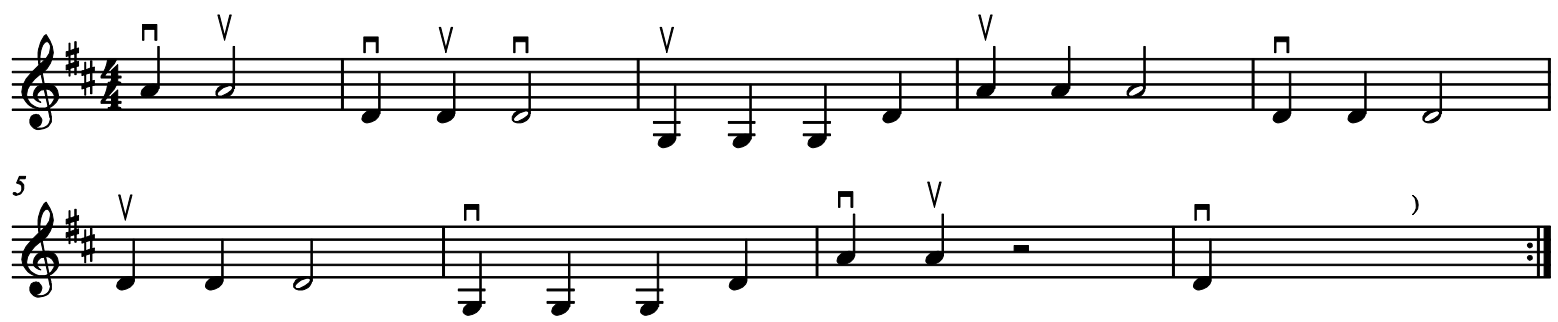
O exercício seguinte é o mesmo que o anterior, acrescido da linha do professor. A tonalidade apresentada é de ré maior.

\section{8a. A canoa virou 1a}
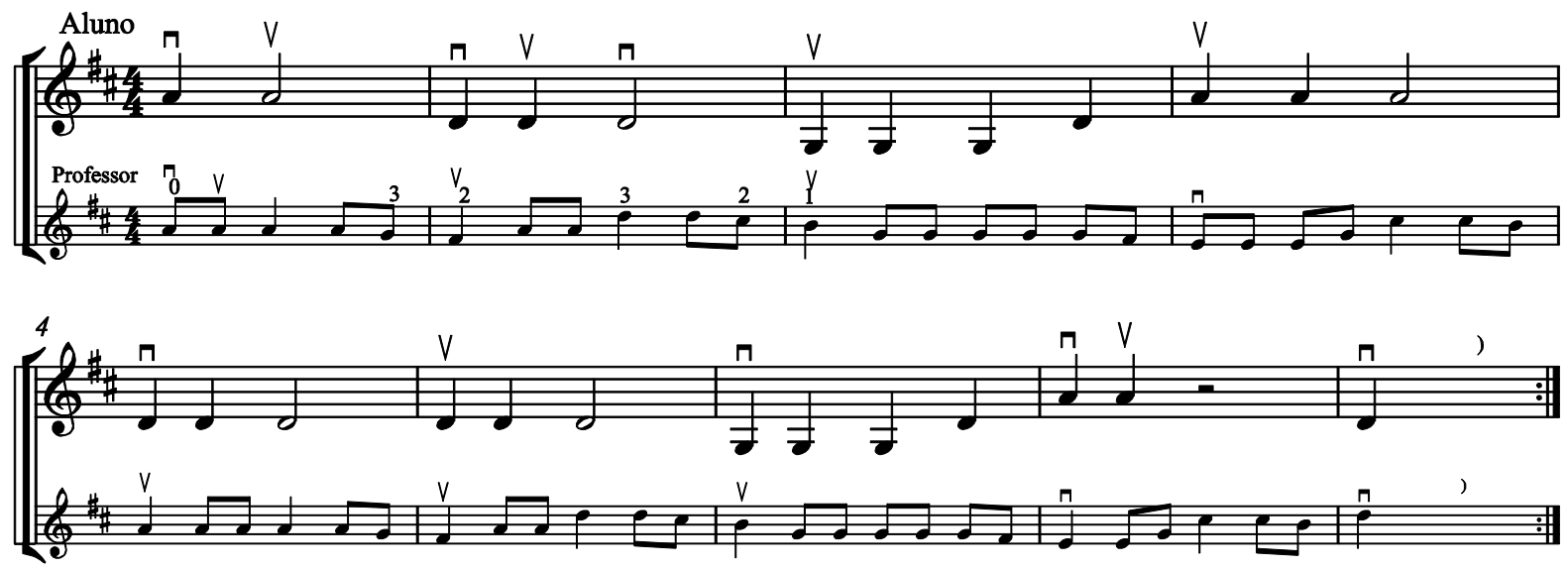

O exercício 19 desenvolve a questão da retomada de arco e de síncopas nas quatro cordas, mi, lá, ré e sol.

\section{Síncopa e retomada de arco em todas as cordas}

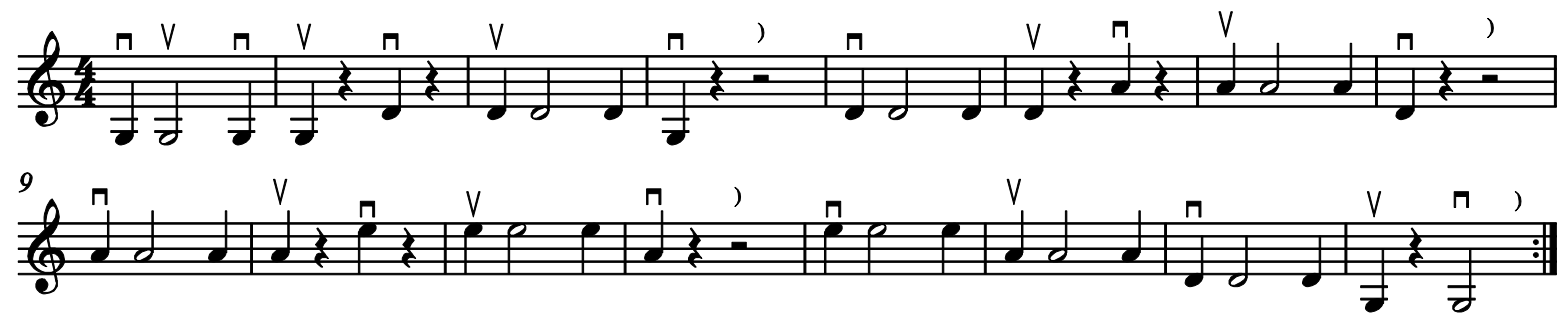

\section{Lição 2}

A lição 2 é composta por 10 exercícios, do número 20 ao 29. O conteúdo técnico desenvolvido nesta lição segue abaixo:

- Figura musical da semibreve;

- Pizzicato de mão direita no início dos exercícios técnicos;

- Colocação do primeiro dedo da mão esquerda na corda ré, resultando na nota mi dedilhada, marcado com o número 1 indicativo de seu dedilhado, logo acima ou abaixo da nota; 
- Colocação do primeiro dedo na corda lá, resultando na nota si dedilhada, marcado com o número 1 indicativo de seu dedilhado, logo acima ou abaixo da nota;

- Início do exercício com arcada para cima, posicionamento do arco na ponta;

- Permanência do primeiro dedo na corda;

- Armadura de clave com indicação de tonalidade.

O exercício 20 apresenta a colocação do primeiro dedo da mão esquerda na terceira corda do violino, a corda ré. A nota tocada com este primeiro dedo preso é o mi, que recebe o número 1 do dedilhado, logo acima da nota.

Para realizar este exercício 20, é necessário que o aluno estude o exercício preparatório 39, no capítulo 3.2.2 O violino da presente tese.

A marcação do dedilhado segue a seguinte lógica: ele será marcado apenas no início de sua aparição no exercício, pois, uma vez sendo compreendido pelo aluno, não se julga necessário marcar a repetição desse dedilhado todas as outras vezes em que a nota aparecer ao longo do exercício.

Uma vez marcado um dedilhado, supõe-se que todas as notas iguais subsequentes utilizarão o mesmo dedo até que um novo dedilhado apareça na partitura. A marcação repetida do dedilhado somente ocorrerá quando houver a necessidade de relembrar o aluno sobre ele, ou quando, após uma mudança de dedilhado, indicamos a volta ao anterior.

A partir de agora, os exercícios técnicos serão precedidos por dois compassos de pizzicato em corda solta com a mão esquerda, com a finalidade de trazer a palma da mão esquerda do aluno para perto do espelho do violino, para que ele possa conseguir manter a forma redonda e curva dos dedos da mão esquerda sobre as cordas, especialmente do dedo mínimo.

Dessa maneira, o aluno se prepara para obter maior velocidade, agilidade e afinação com a mão esquerda, além de obter ganhos de flexibilidade e relaxamento muscular nessa região.

Também aparece na linha do aluno a armadura de clave com a tonalidade indicada. Quando chegar ao final do exercício, o aluno deve realizar uma retomada de arco e tocar da barra de repetição escrita no início do terceiro compasso. 


\section{Primeiro dedo na corda $\operatorname{Re}$}

A partir deste exercício em diante, faremos pizzicato com a mão esquerda no início, para manter a palma e dedos da mão esquerda próximos do espelho e cordas.

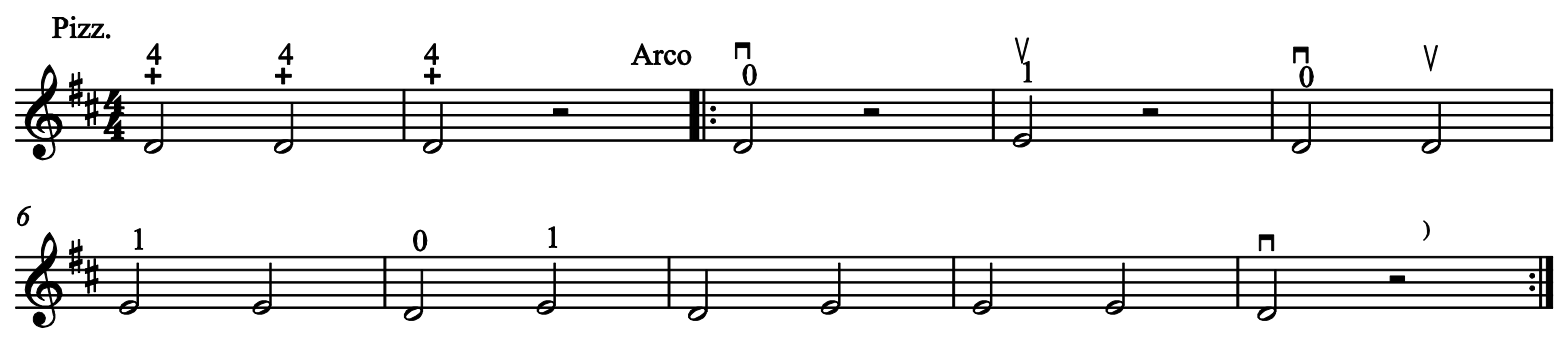

O exercício 21 apresenta a figura musical da semibreve na corda ré e com o primeiro dedo mi. A semibreve é somente introduzida neste momento do aprendizado por ser uma figura de longa duração, que para ser executada exige maior controle motor do arco sobre a corda, que é difícil para o aluno principiante logo no início do aprendizado.

\section{Semibreve}
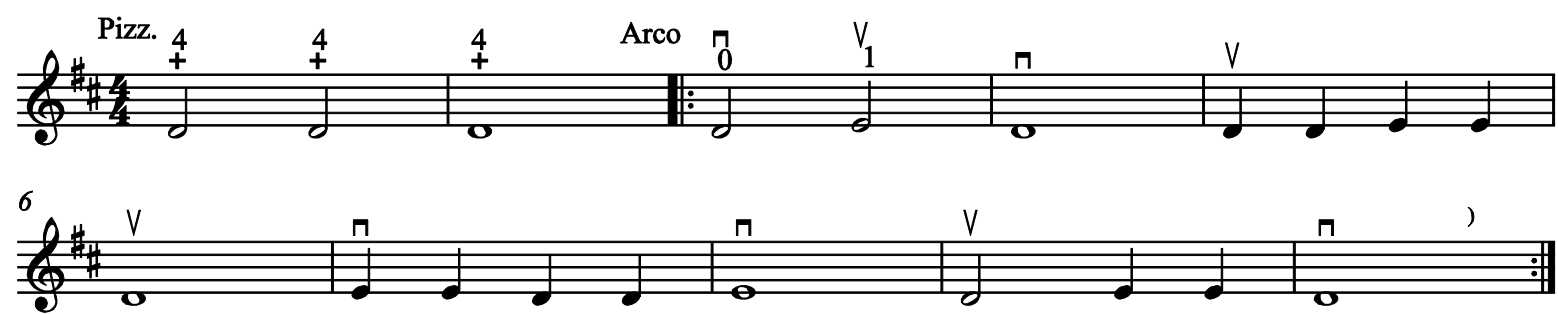

O exercício 22 apresenta síncopas nas figuras rítmicas de semínimas, mínimas e semibreves, com uso do primeiro dedo na corda ré.

22.
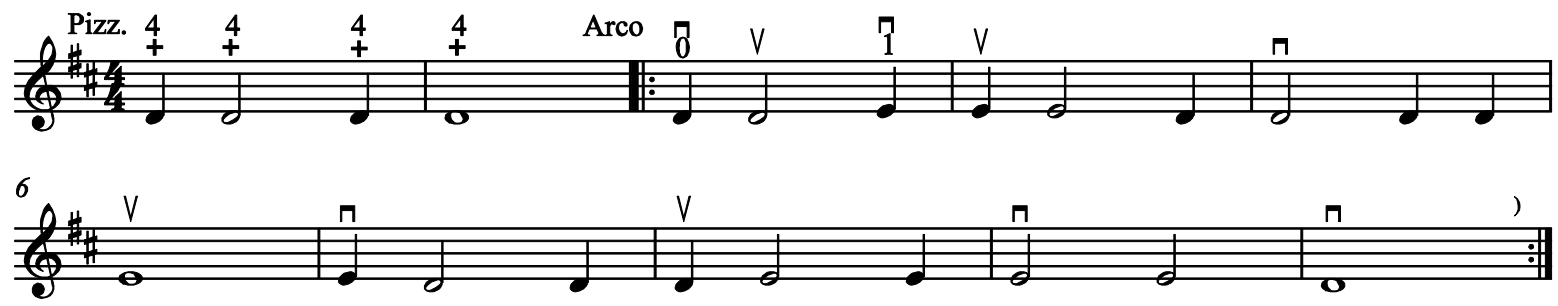
O exercício 23 apresenta a colocação do primeiro dedo da mão esquerda na corda lá. A nota tocada com esse primeiro dedo preso é si, que recebe o número 1 do dedilhado, logo acima da nota.

\section{Primeiro dedo na corda La}
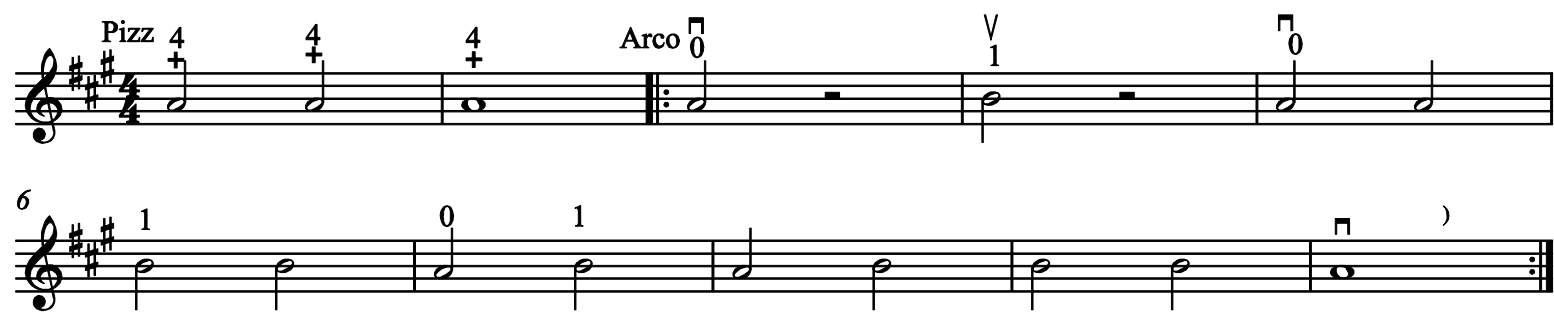

O exercício 24 apresenta variações rítmicas e de arcadas com as notas lá e si efetuadas na corda lá através de semínimas, mínimas e semibreve. O objetivo é exercitar a troca entre a corda solta e o primeiro dedo preso com maior agilidade, uma vez que as figuras rítmicas são mais rápidas neste exercício em comparação com o anterior.

24.
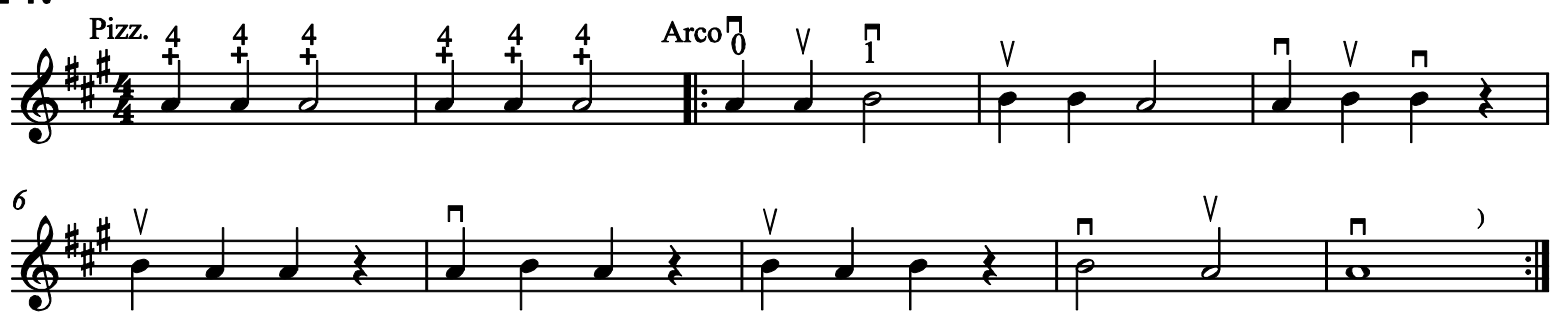

O exercício 25 apresenta maior grau de dificuldade ao efetuar as trocas entre a corda solta e o primeiro dedo utilizando pausas entre as notas sem um padrão, exigindo a correta contagem do tempo pelo aluno. $\mathrm{O}$ arco deve permanecer na corda durante as pausas.

25.
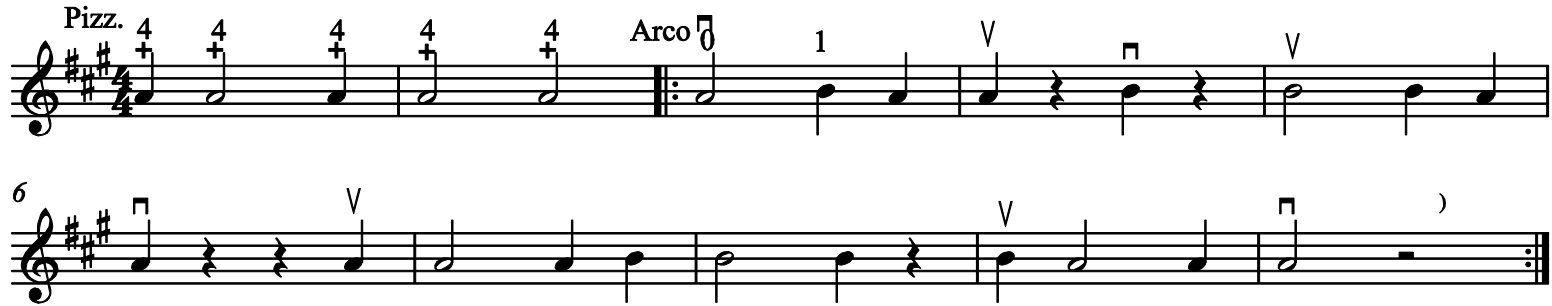
O exercício 26 apresenta a primeira linha melódica coadjuvante para a canção folclórica Capelinha de melão. Traz um novo elemento técnico, que é o início do exercício com arcada para cima, com o arco posicionado na ponta. Para este exercício, é necessário desenvolver previamente o posicionamento do arco na ponta antes do início descrito no exercício preparatório 33 no capítulo 3.2.1 $O$ arco da presente tese.

\section{Capelinha de melão 1 - início com arco para cima}

Antes do início do exercício, arco deve estar posicionado na ponta com a vareta paralela ao cavalete.

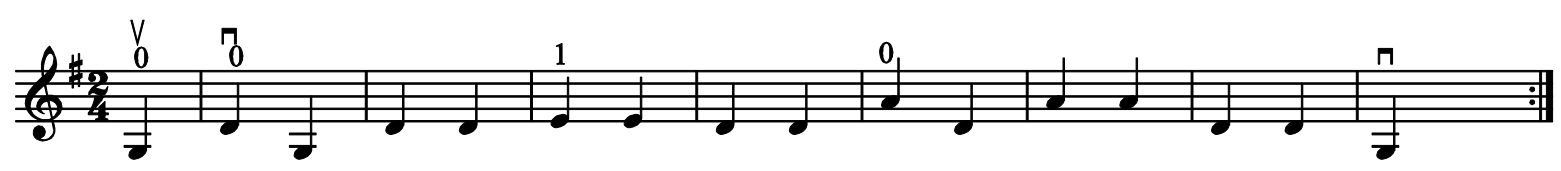

O exercício seguinte é o mesmo que o anterior acrescido da linha do professor. A tonalidade apresentada é de sol maior. Aqui novamente encontramos a mesma orientação dada no exercício 9 , e a linha do aluno não pede retomada de arco, diferentemente da linha do professor.

\section{6a. Capelinha de melão 1a}

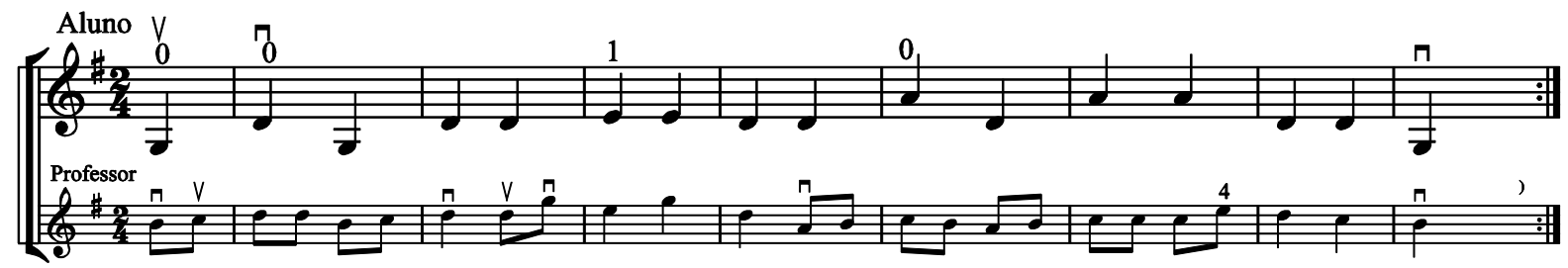

O exercício 27 apresenta a segunda linha melódica coadjuvante para a canção folclórica Caranguejo. As cordas empregadas são lá, ré e sol, com retomada de arco nas pausas. O primeiro dedo será empregado apenas na corda ré, resultando na nota mi marcado cam o número 1 no dedilhado.

\section{Caranguejo 2}
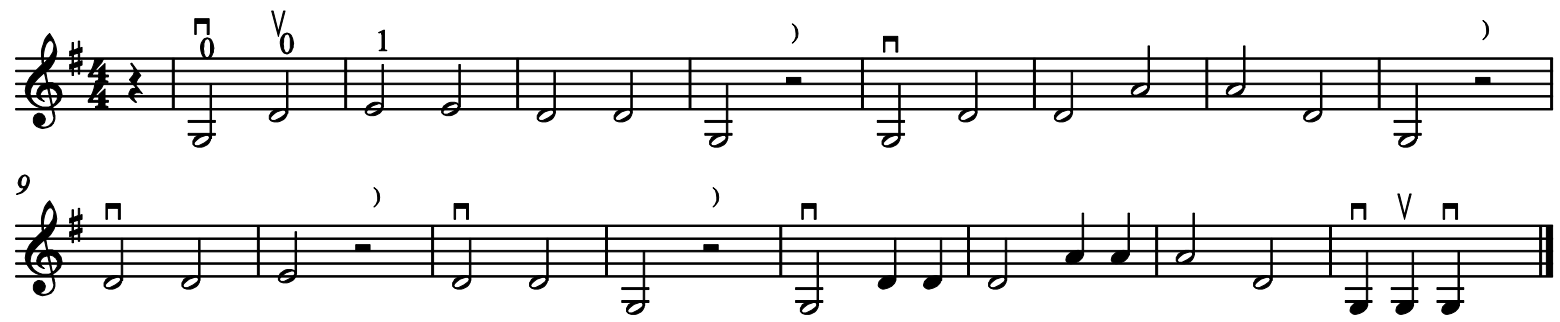
O exercício seguinte é o mesmo que o anterior, acrescido da linha do professor. A tonalidade apresentada é de sol maior.

\section{7a. Caranguejo $2 a$}
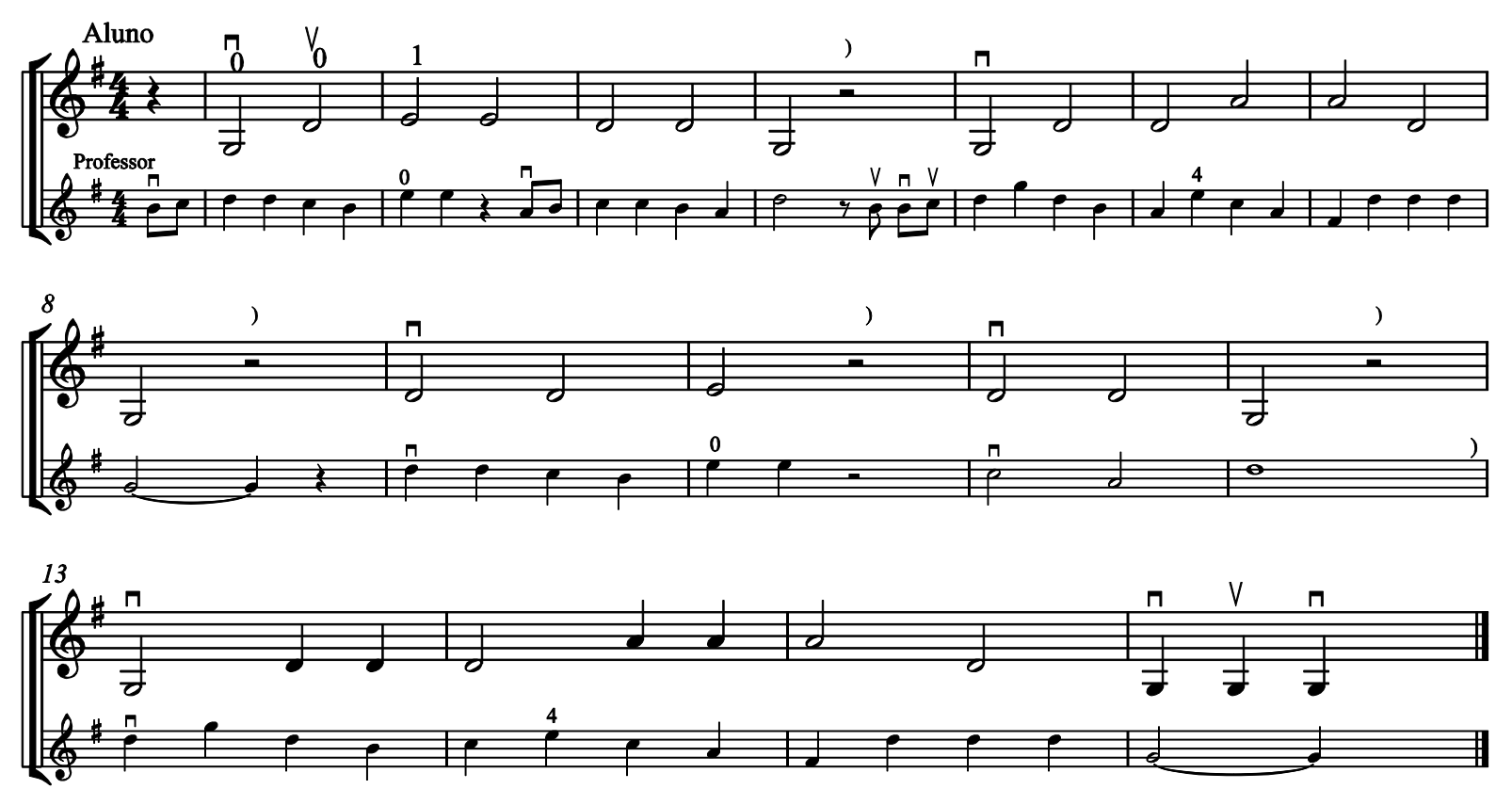

O exercício 28 apresenta a primeira linha melódica coadjuvante para a canção folclórica Fui passar na ponte. O elemento técnico novo apresentado é o da permanência do primeiro dedo sobre a corda ré enquanto o arco toca na corda lá. É indicado na partitura por um longo traço horizontal disposto ao lado direito da marcação do dedilhado.

O aluno deve cuidar para os dedos da mão esquerda estejam sempre curvos e deve prender a corda somente com a polpa da ponta dos dedos. Caso contrário, se a curvatura dos dedos não for suficiente para deixar a corda lá livre, o som produzido ficará sujo por causa da interferência não planejada do primeiro dedo preso, que deve permanecer na corda enquanto durar o traço indicativo.

\section{Fui passar na ponte 1 - permanência do primeiro dedo}

O primeiro dedo deve permanecer preso na corda até o final do traço indicativo.

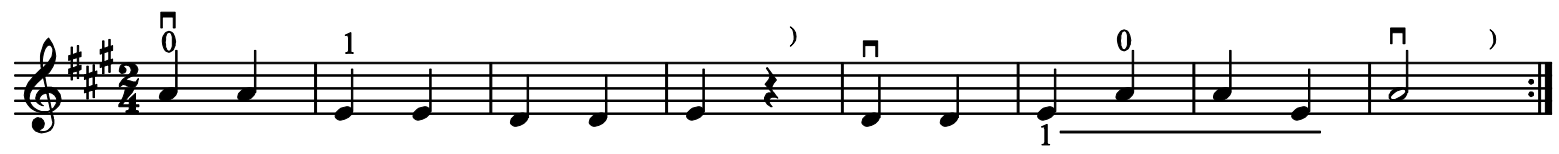


O exercício seguinte é o mesmo que o anterior, acrescido da linha do professor. A tonalidade apresentada é de lá maior.

\section{8a. Fui passar na ponte $1 \mathrm{a}$}

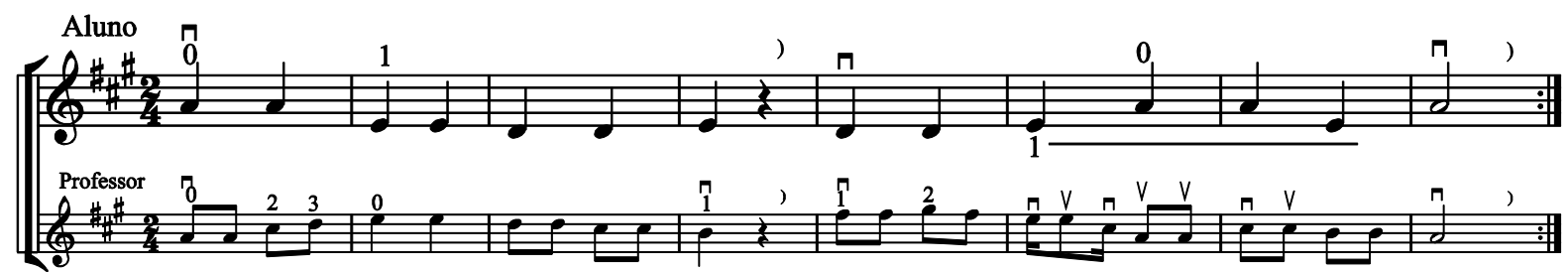

O exercício 29 apresenta a primeira linha melódica coadjuvante para a canção folclórica $\mathrm{Na}$ corda da viola. O arco deve ser posicionado na ponta no início do exercício.

\section{Na corda da viola 1}
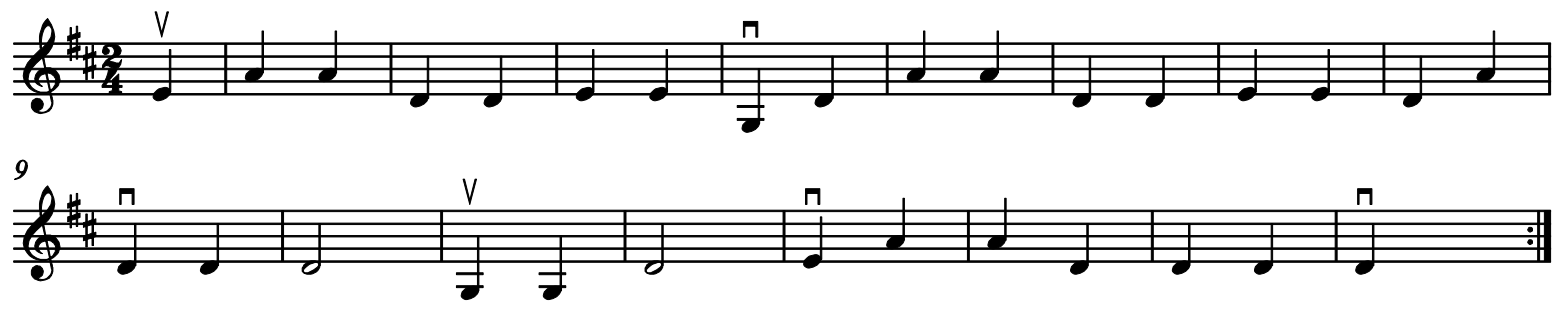

O exercício seguinte é o mesmo que o anterior, acrescido da linha do professor. A tonalidade apresentada é de ré maior.

29a. Na corda da viola 1a
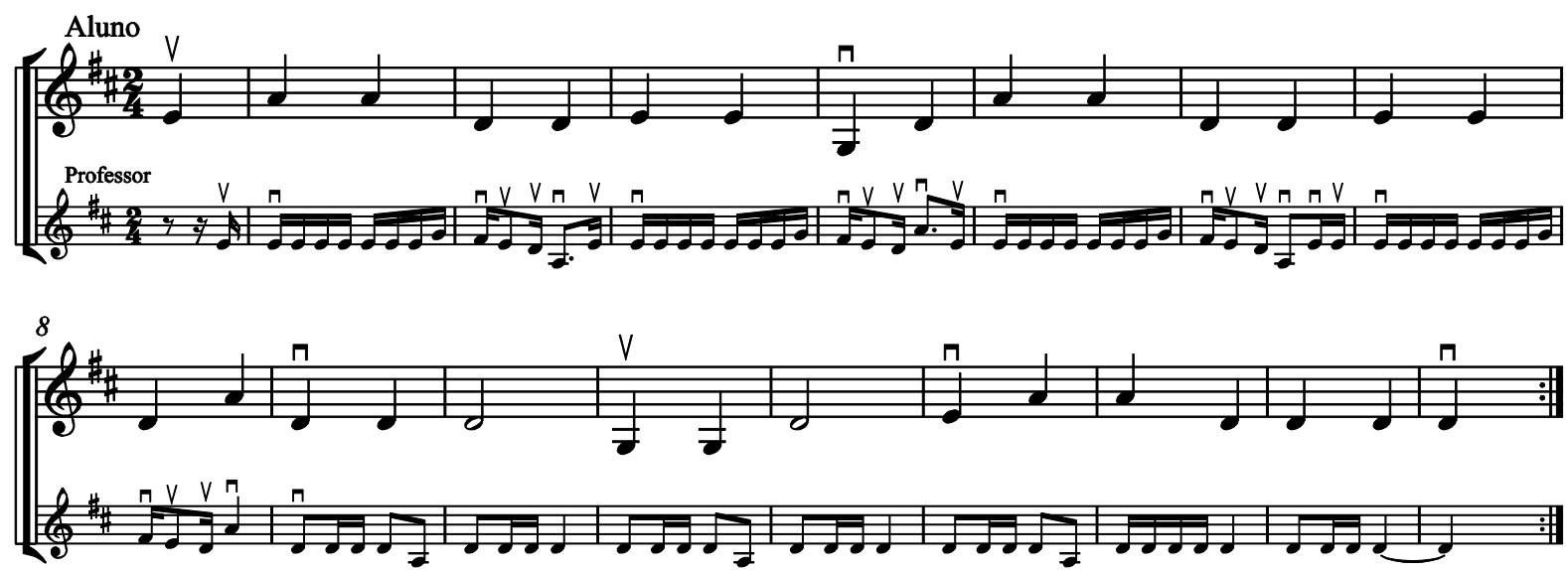


\section{Lição 3}

A lição 3 é composta por 10 exercícios, do número 30 ao 39 . O conteúdo técnico desenvolvido nesta lição segue abaixo:

- Colocação do segundo dedo da mão esquerda sobre a corda ré, resultando na nota fá\#, marcada com o número 2 indicativo de seu dedilhado, logo acima ou abaixo da nota;

- Máximo de permanência dos dedos sobre as cordas;

- Salto de intevalo com colocação de dedos, dedilhado 0 (corda solta) seguido de 2 (dois dedos sobre a corda);

- Colocação do segundo dedo sobre a corda lá, resultando na nota dó\#, marcada com o número 2 indicativo de seu dedilhado, logo acima ou abaixo da nota;

O exercício 30 apresenta a colocação do segundo dedo da mão esquerda na terceira corda do violino, a corda ré. A nota tocada com esse segundo dedo preso é o fá\#, que recebe o número 2 do dedilhado, logo acima da nota.

Neste início de aprendizado o aluno deve deixar o maior número de dedos em contato com a corda durante todos os exercícios. Por essa razão, o aluno deve colocar e manter os dois dedos em contato com a corda, e não retirar o primeiro dedo da corda assim que colocar o segundo.

Essa recomendação tem por objetivo desenvolver a forma da mão do aluno, facilitar a afinação e a velocidade na mão esquerda.

\section{Segundo dedo na corda Ré}
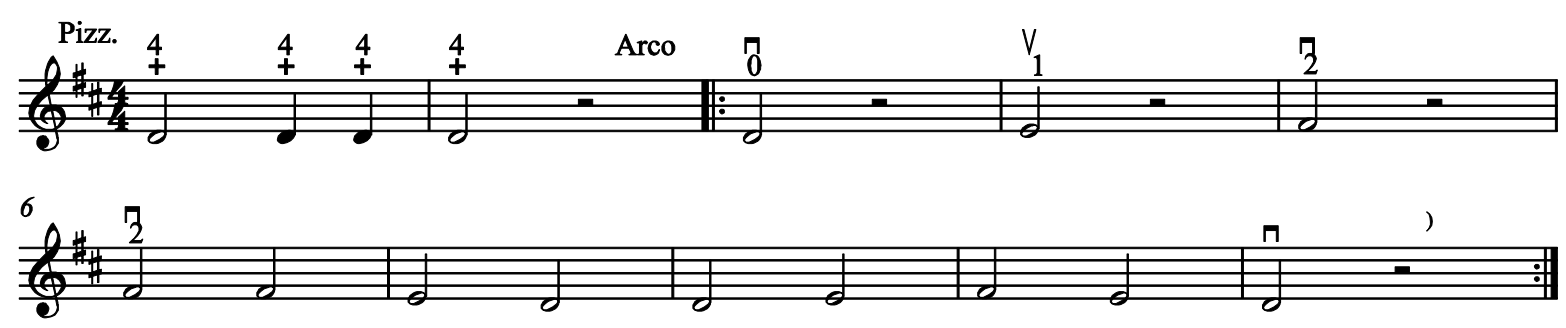
O exercício 31 apresenta o uso do primeiro e do segundo dedo na corda ré, resultando nas notas mi e fá\# em graus conjuntos.

31.
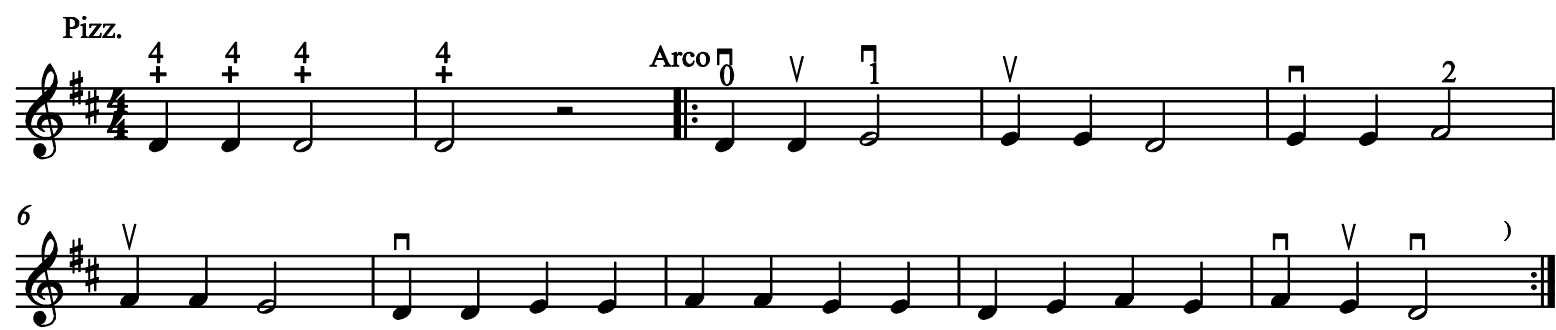

O exercício 32 apresenta a primeira linha melódica coadjuvante para a canção folclórica Hei de namorar, com o primeiro e o segundo dedos presos na corda ré, em graus conjuntos e disjuntos. O uso de corda solta seguido do segundo dedo preso na corda (dedilhado 0-2) deve ser exercitado pelo aluno, que deve colocar sempre os dois dedos ao mesmo tempo na corda.

\section{Hei de namorar 1}
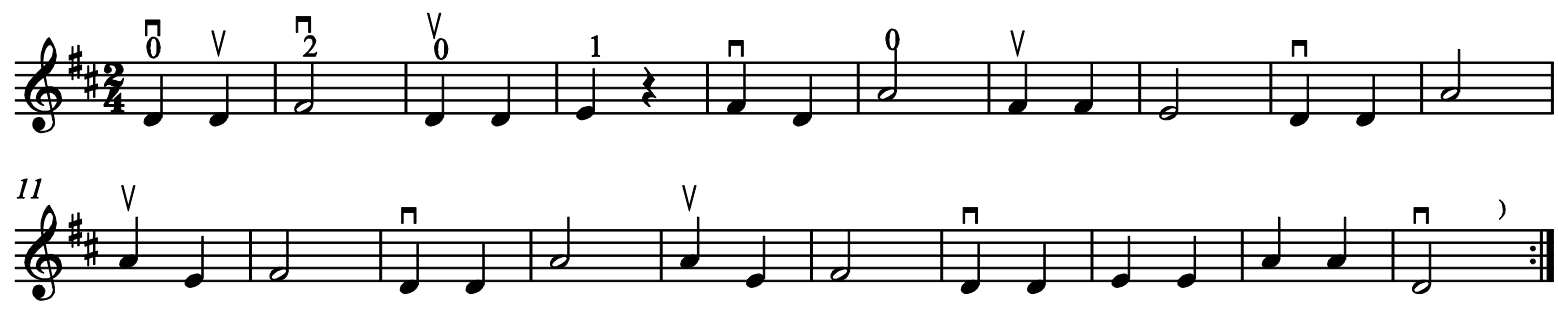

O exercício seguinte é o mesmo que o anterior, acrescido da linha do professor. A tonalidade apresentada é de ré maior.

\section{2a. Hei de namorar 1a}
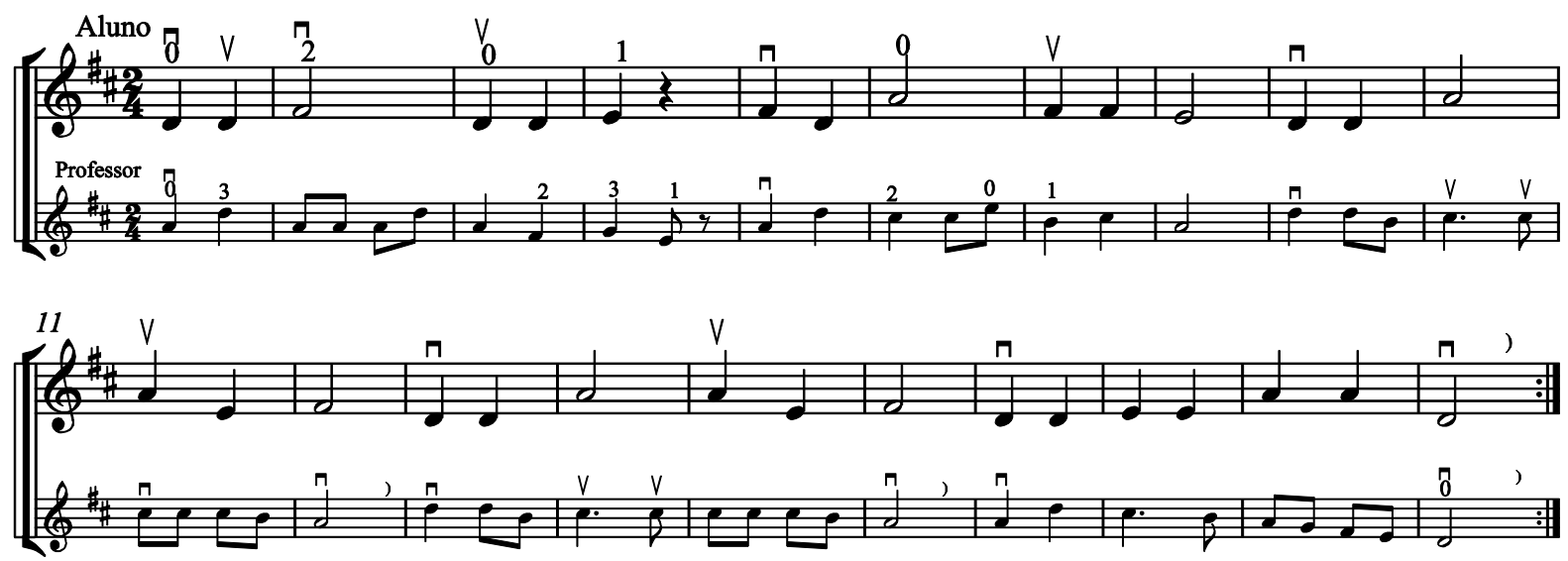
O exercício 33 apresenta a colocação do segundo dedo da mão esquerda na terceira corda do violino, a corda lá. A nota tocada com esse segundo dedo preso é o dó\#, que recebe o número 2 do dedilhado, logo acima da nota.

\section{Segundo dedo na corda La}

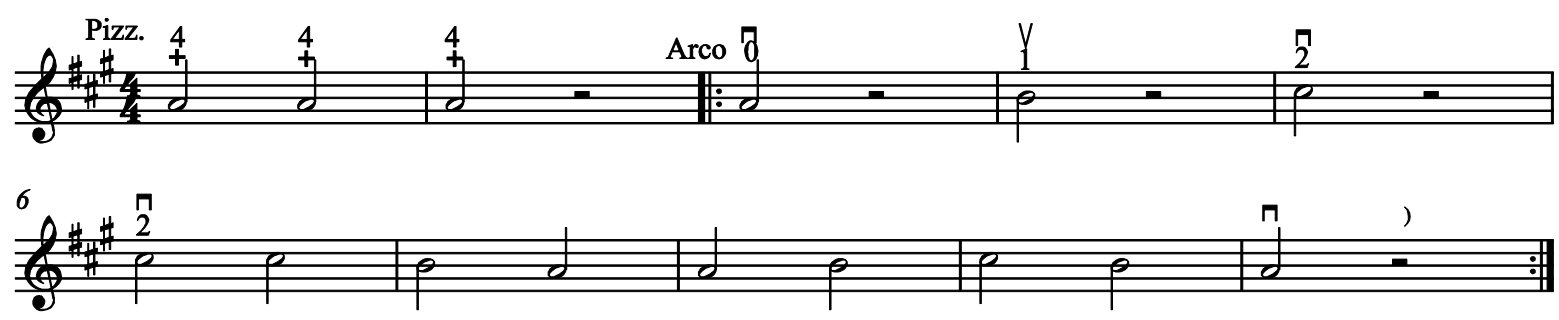

O exercício 34 apresenta o uso do primeiro e do segundo dedo na corda lá, resultando nas notas si e dó\# em graus conjuntos.

34.
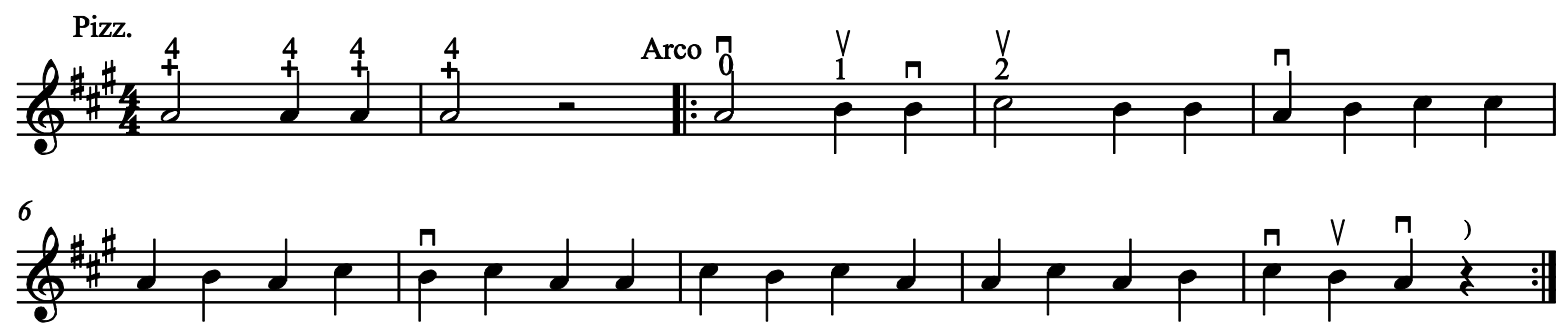

O exercício 35 apresenta a primeira linha melódica coadjuvante para a canção folclórica Uma, duas angolinhas. O arco deve ser posicionado na ponta no início do exercício.

\section{Uma, duas angolinhas 1}

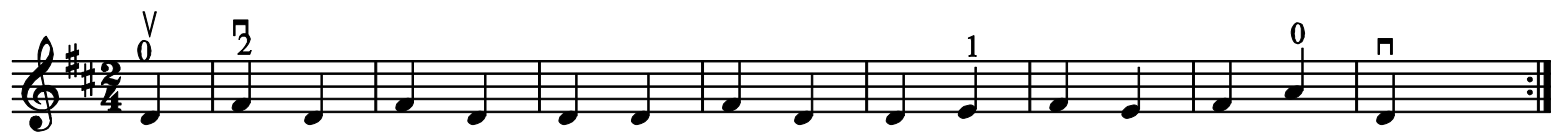


O exercício seguinte é o mesmo que o anterior, acrescido da linha do professor. A tonalidade apresentada é de ré maior.

35a. Uma, duas angolinhas 1a

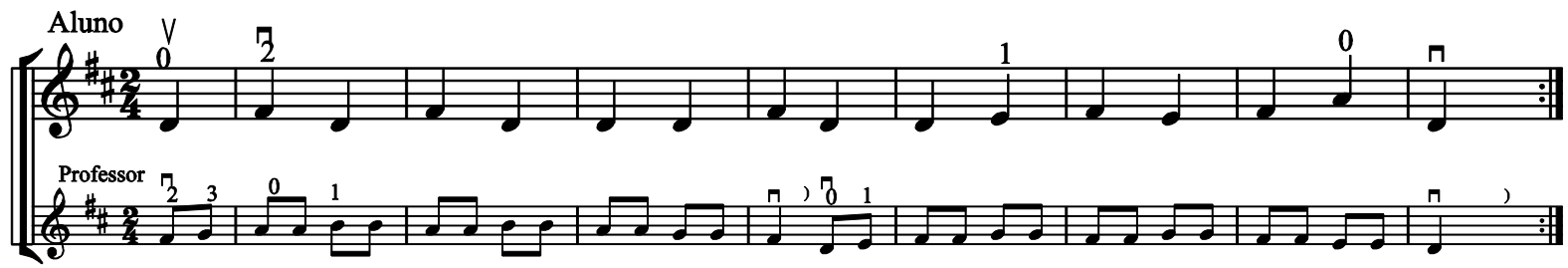

O exercício 36 apresenta a primeira linha melódica coadjuvante para a canção folclórica As conchinhas.

\section{As conchinhas 1}
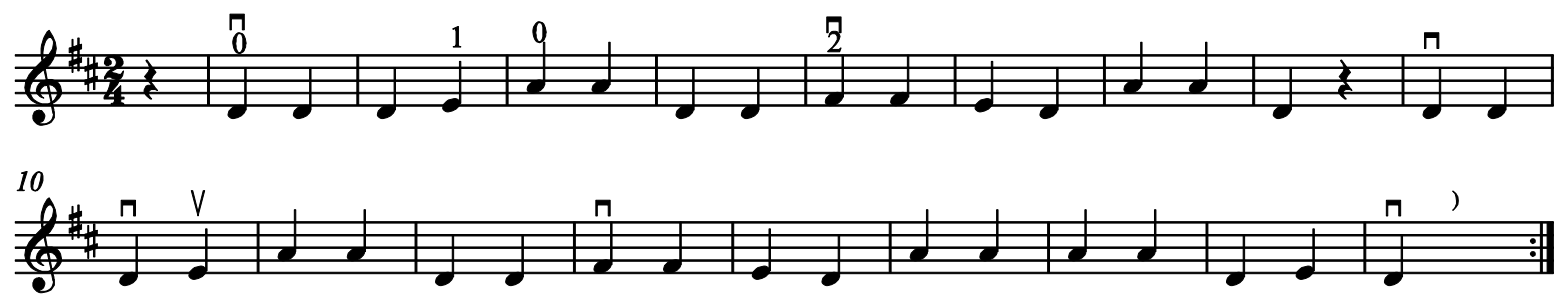

O exercício seguinte é o mesmo que o anterior, acrescido da linha do professor. A tonalidade apresentada é de ré maior.

36a. As conchinhas 1a
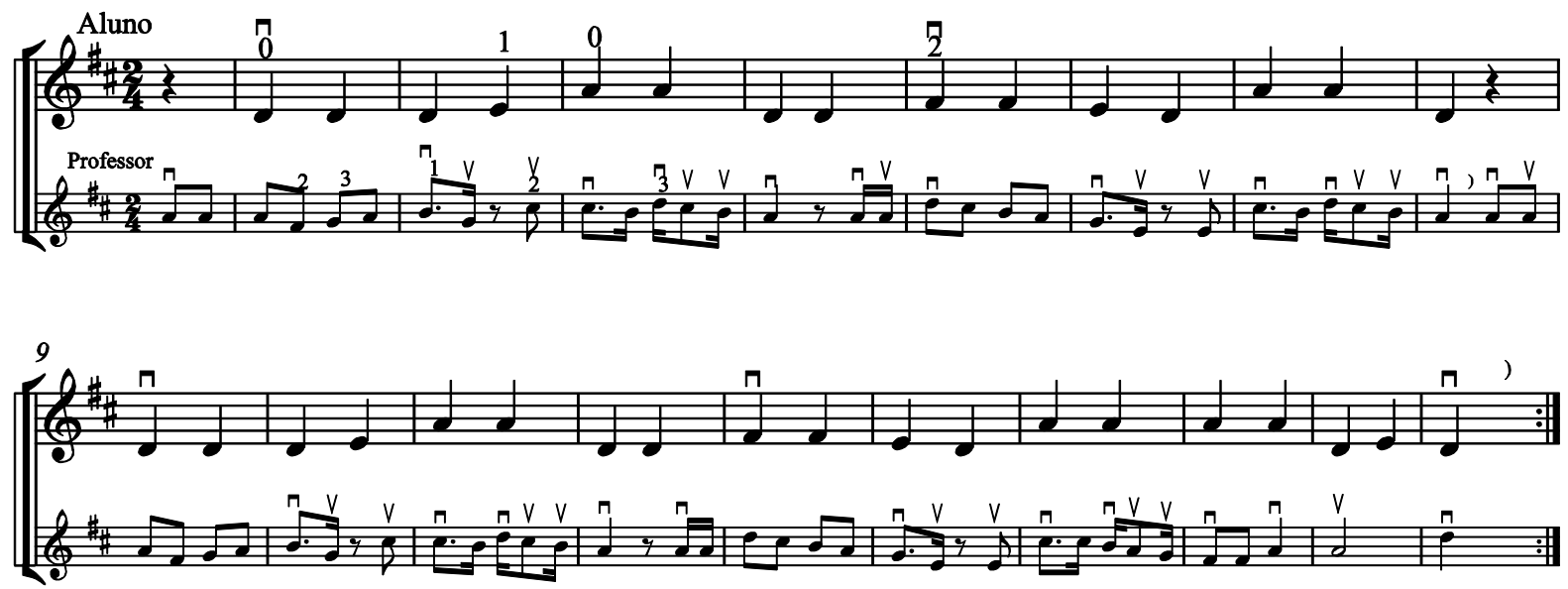
O exercício 37 apresenta a primeira linha melódica coadjuvante para a canção folclórica $O$ pobre e o rico. O dedilhado requer o uso do primeiro e do segundo dedos nas cordas lá e ré.

\section{0 pobre e o rico 1}

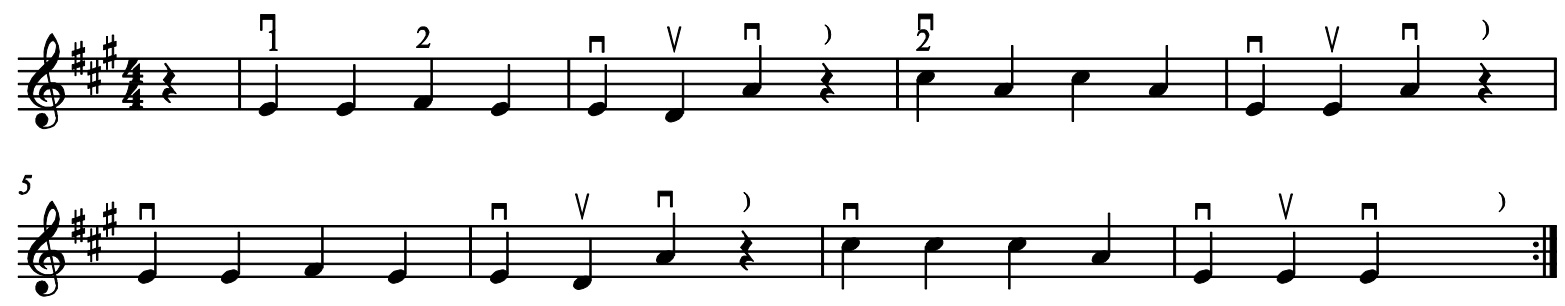

O exercício seguinte é o mesmo que o anterior, acrescido da linha do professor. A tonalidade apresentada é de lá maior.

\section{7a. 0 pobre e o rico $1 \mathrm{a}$}
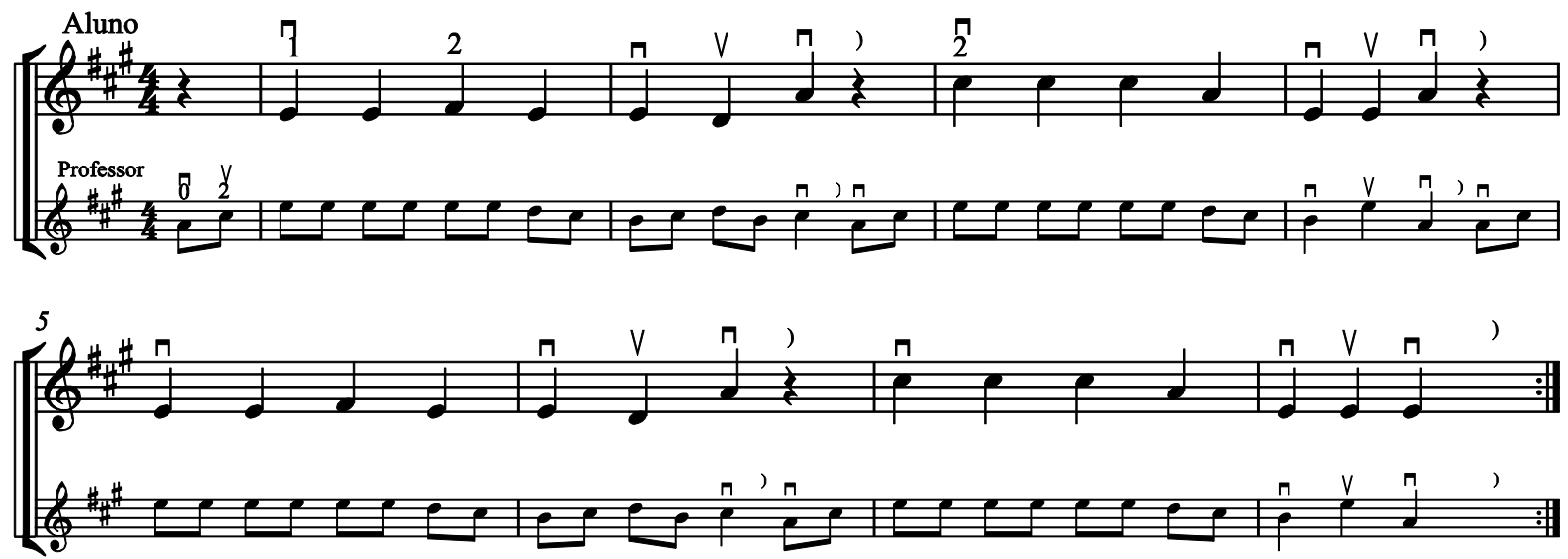

O exercício 38 apresenta a primeira linha melódica coadjuvante para a canção folclórica Senhora dona Sancha. Entre a primeira e segunda linha do exercício é necessário fazer a retomada do arco.

\section{Senhora dona Sancha 1}
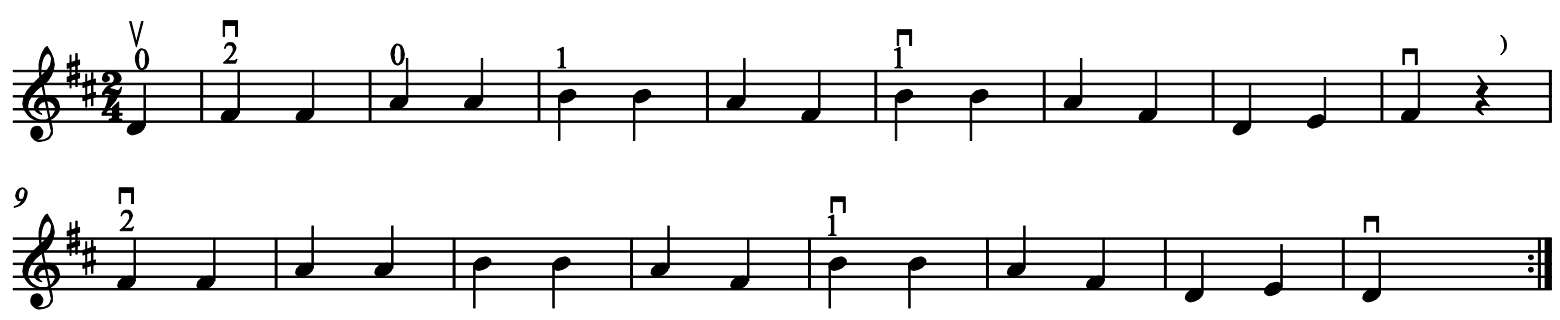
O exercício seguinte é o mesmo que o anterior, acrescido da linha do professor. A tonalidade apresentada é de ré maior.

\section{8a. Senhora dona Sancha 1a}

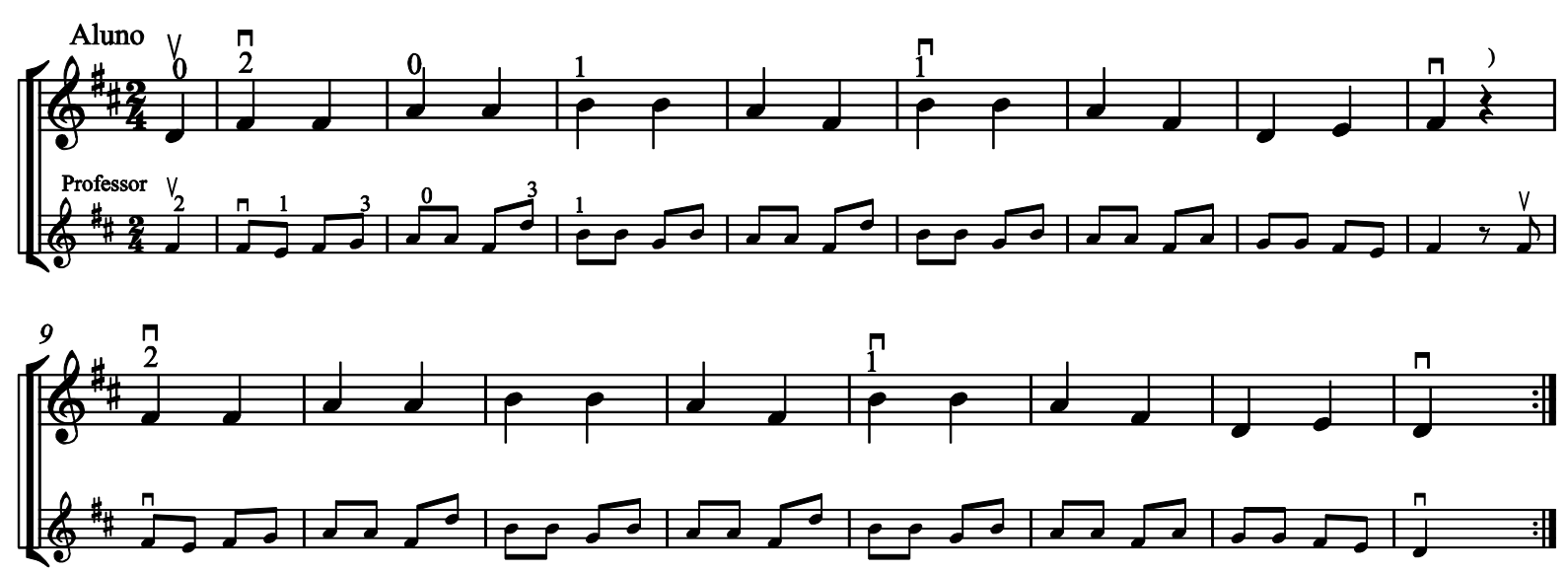

O exercício 39 apresenta o uso do primeiro e do segundo dedos nas cordas lá e ré, com retomadas de arco nas pausas.

39.

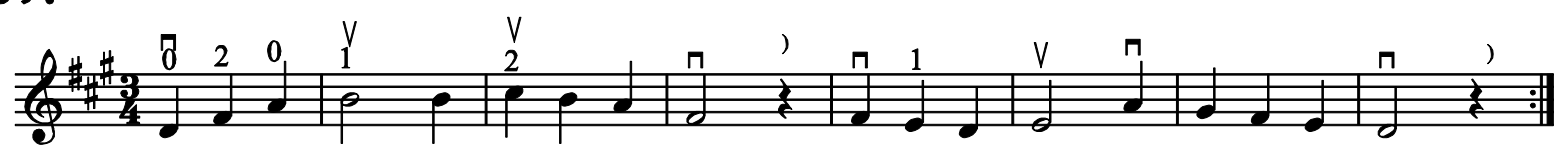

\section{Lição 4}

A lição 4 é composta por 10 exercícios, do número 40 ao 49 . O conteúdo técnico desenvolvido nesta lição segue abaixo:

- Colocação do terceiro dedo na corda ré, resultando na nota sol dedilhada, marcada com o número 3 indicativo de seu dedilhado, logo acima ou abaixo da nota;

- Figura rítmica da colcheia;

- Síncopas em mínimas, semínimas e colcheias;

- Colocação do terceiro dedo na corda lá, resultando na nota ré dedilhada, marcada com o número 3 indicativo de seu dedilhado, logo acima ou abaixo da nota; 
O exercício 40 apresenta a colocação do terceiro dedo na corda ré, resultando na nota sol dedilhada, marcada com o número 3 , indicativo de seu dedilhado.

\section{Terceiro dedo na corda $\mathrm{Re}$}
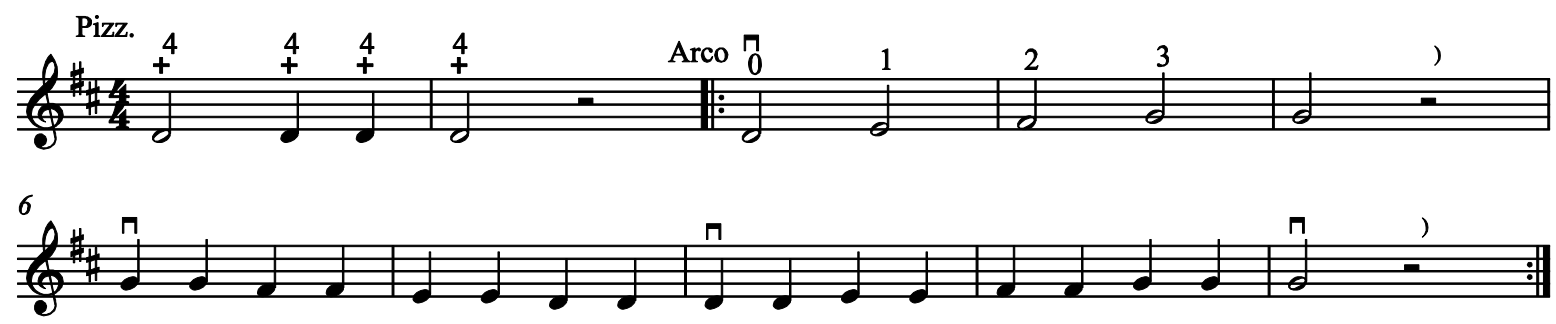

O exercício 41 apresenta a figura rítmica das colcheias. São utilizados 0 primeiro, o segundo e o terceiro dedos na corda ré, resultando nas notas mi, fá\# e sol.

\section{Colcheias}

Pizz.
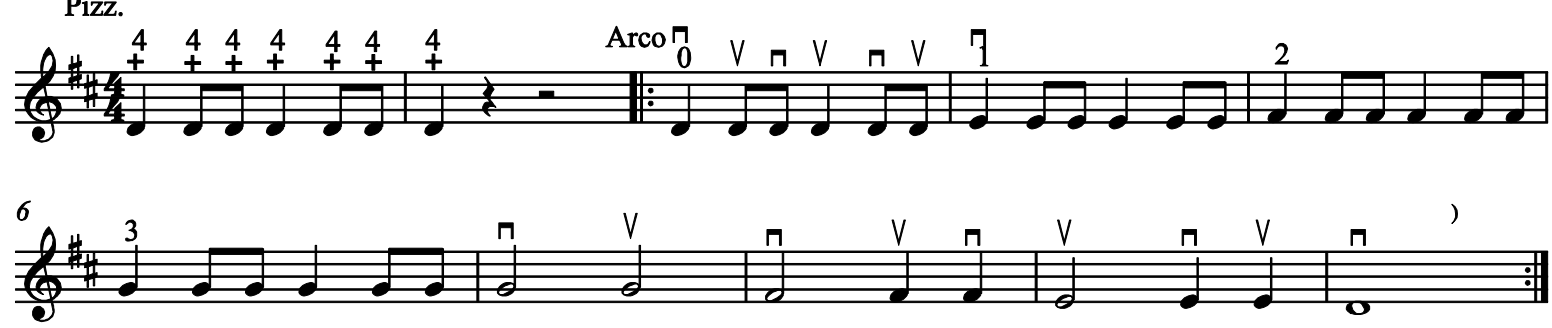

O exercício 42 apresenta o uso do primeiro, do segundo e do terceiro dedos na corda ré em semínimas e colcheias alternadas.

42.

Pizz.
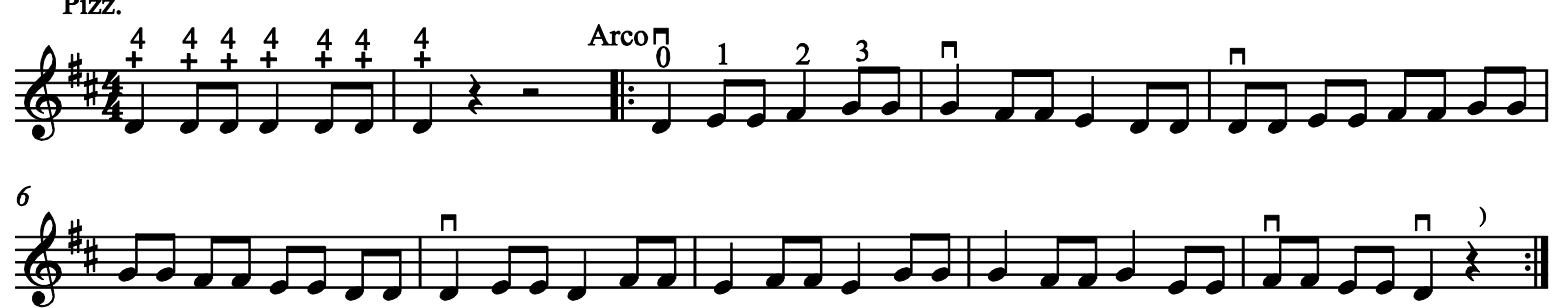
O exercício 43 apresenta a colocação do terceiro dedo na corda lá, resultando na nota ré dedilhada, marcada com o número 3 , indicativo de seu dedilhado. 0 exercício também apresenta síncopas em mínimas e semínimas.

\section{Terceiro dedo na corda La}

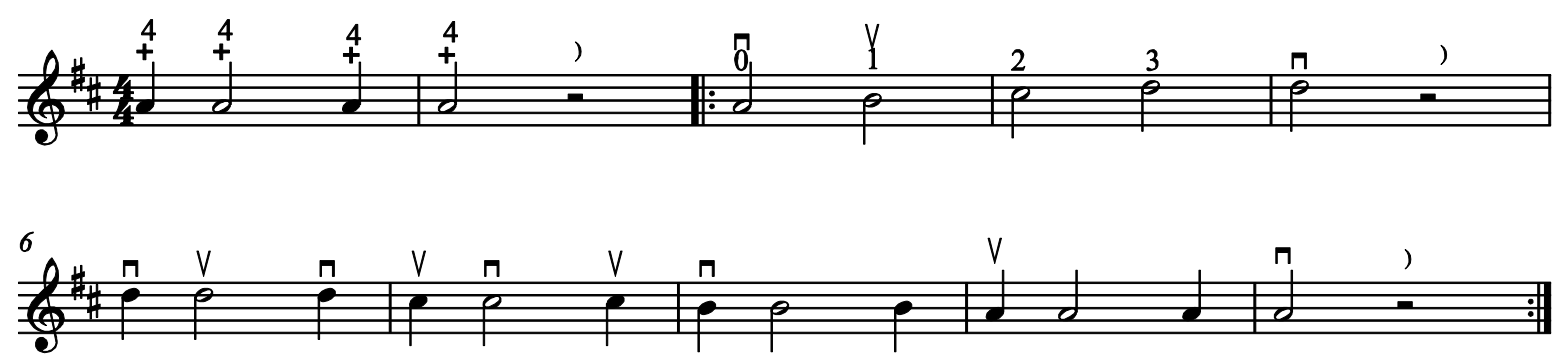

O exercício 44 apresenta o uso do primeiro, do segundo e do terceiro dedos na corda lá em semínimas e colcheias alternadas.

44.
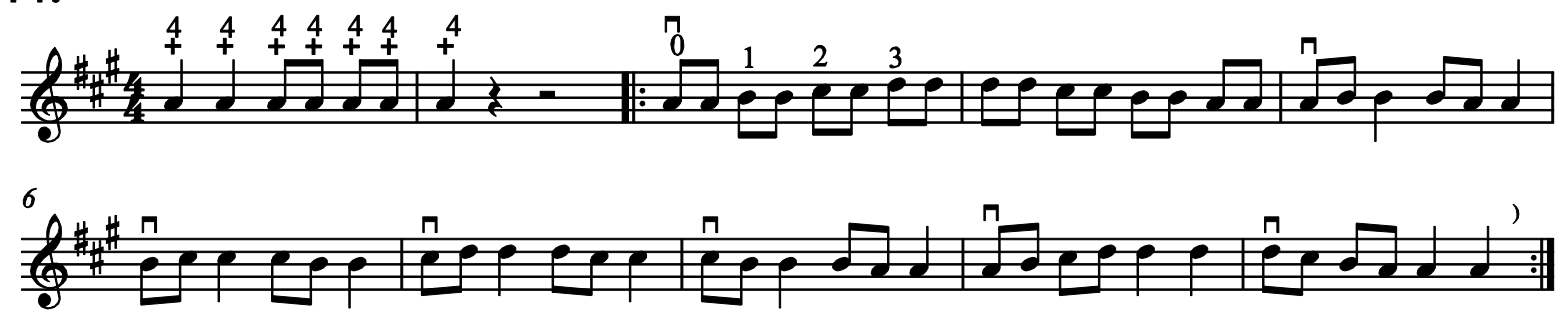

O exercício 45 apresenta síncopas em colcheias com uso do primeiro, do segundo e do terceiro dedos na corda lá, resultando nas notas si, dó\# e ré.

\section{Síncopas}
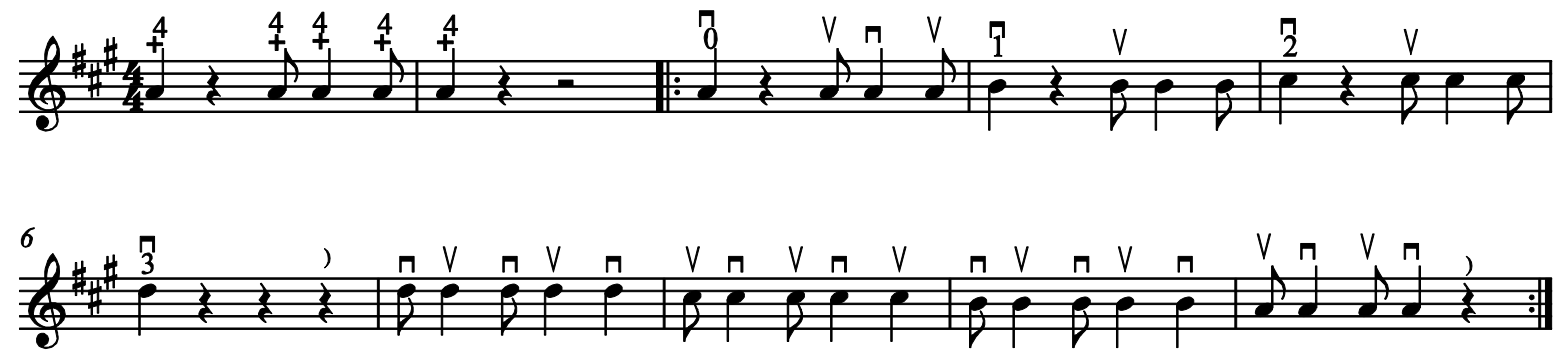
O exercício 46 apresenta a segunda linha melódica coadjuvante para a canção folclórica Ó ciranda, ó cirandinha. Os três dedos da mão esquerda são usados apenas na corda ré, em semínimas e colcheias.

46. Ó ciranda, ó cirandinha 2
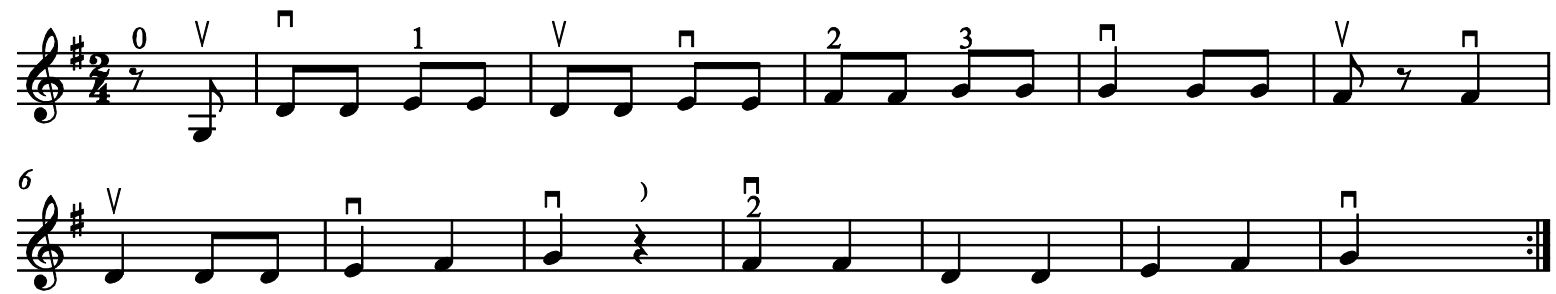

O exercício seguinte é o mesmo que o anterior, acrescido da linha do professor. A tonalidade apresentada é de sol maior.

\section{6a. Ó ciranda, ó cirandinha 2a}
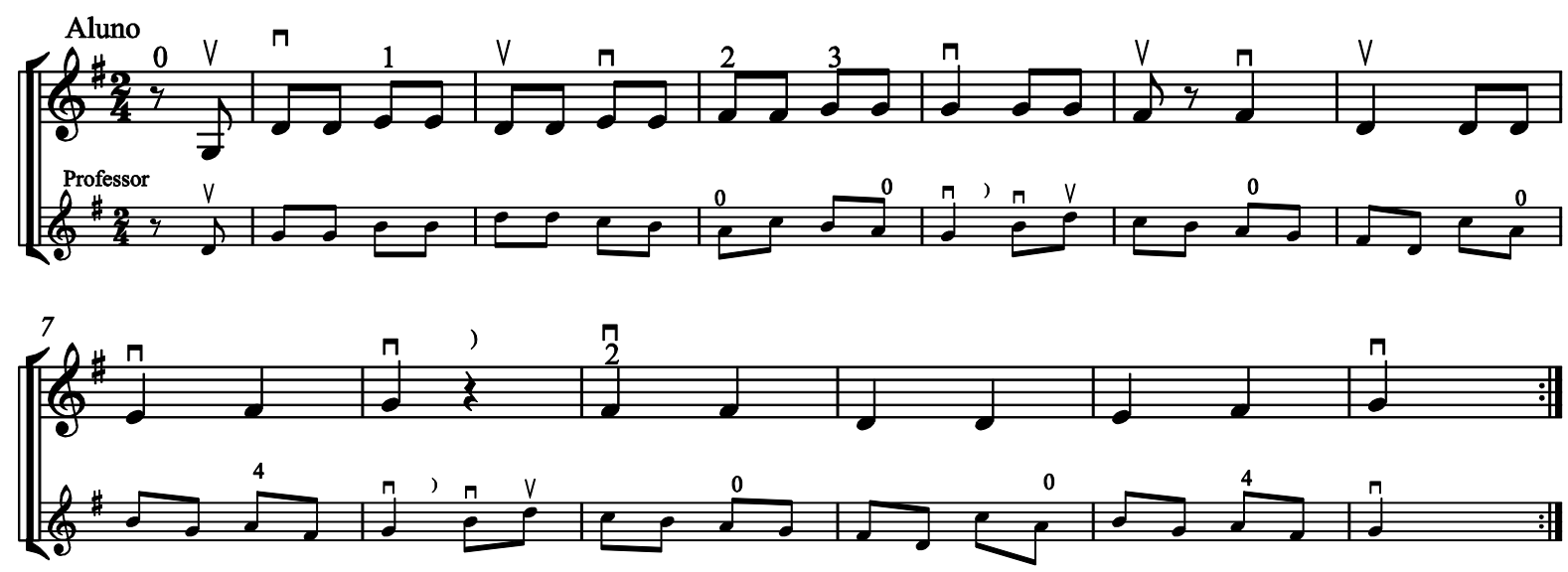

O exercício 47 apresenta a primeira linha melódica coadjuvante para a canção folclórica Sinhá Aninha.

\section{Sinhá Aninha 1}
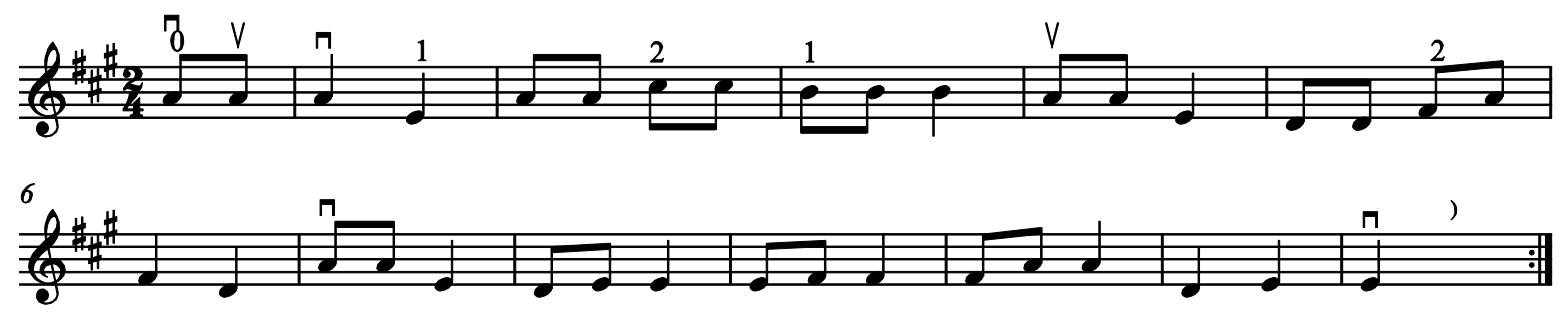
O exercício seguinte é o mesmo que o anterior, acrescido da linha do professor. A tonalidade apresentada é de lá maior.

\section{7a. Sinhá Aninha 1a}
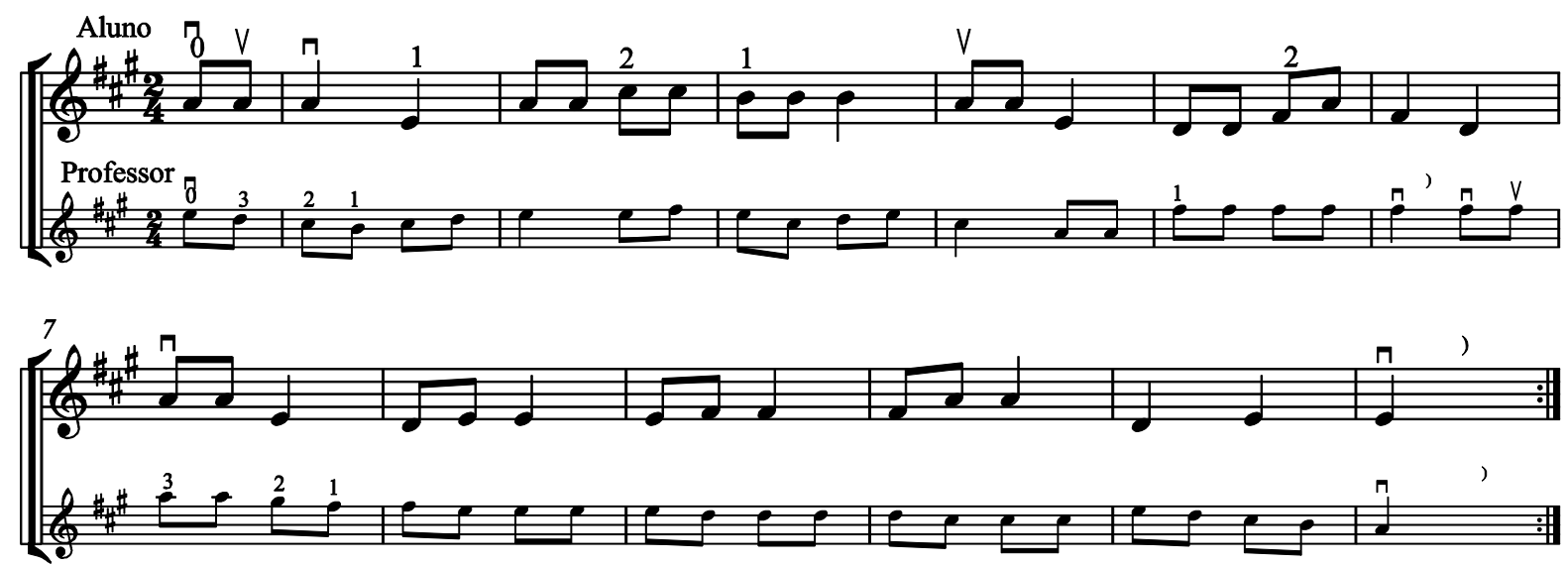

O exercício 48 apresenta a primeira linha melódica coadjuvante para a canção folclórica Rosa Amarela.

\section{Rosa amarela 1}

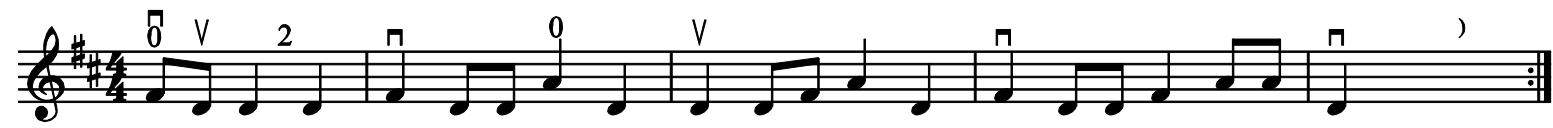

O exercício seguinte é o mesmo que o anterior, acrescido da linha do professor. A tonalidade apresentada é de ré maior.

\section{8a. Rosa amarela 1a}

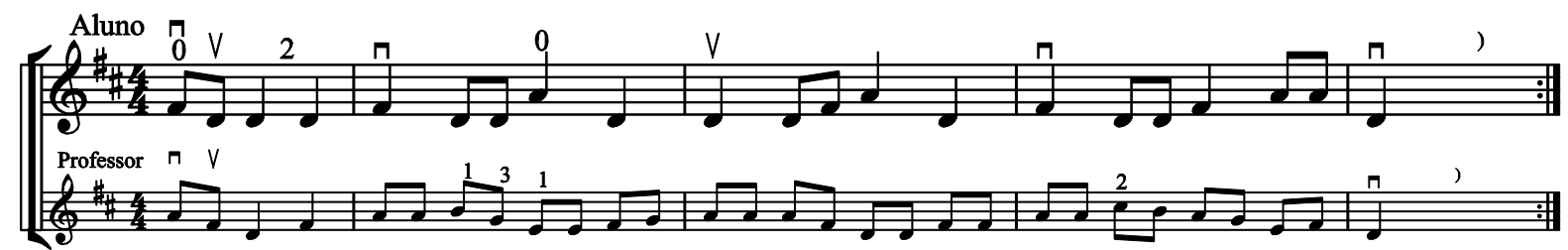

O exercício 49 apresenta a primeira linha melódica coadjuvante para a canção folclórica Pirulito. 
158

O início do exercício requer o uso da arcada para cima, e o aluno deve posicionar seu arco perto da ponta antes do início do exercício, e tocar apenas na metade superior do arco.

49. Pirulito 1

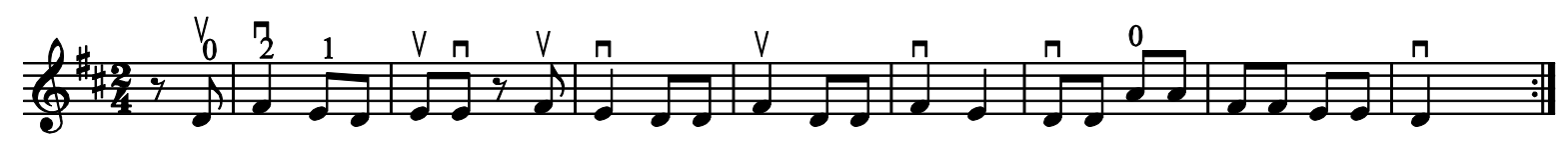

exercício seguinte é o mesmo que o anterior, acrescido da linha do professor. A tonalidade apresentada é de ré maior.

50.

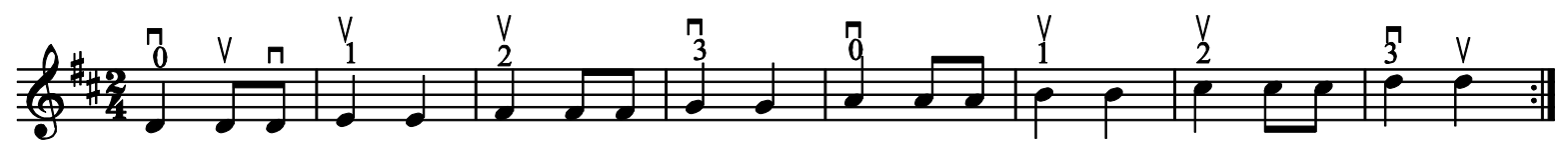

Lição 5

A lição 5 é composta por 10 exercícios, do número 50 ao 59 . O conteúdo técnico desenvolvido nesta lição segue abaixo:

- Escala de ré maior ascendente e descendente na extensão de uma oitava, com uso do primeiro, do segundo e do terceiro dedos nas cordas ré e lá;

- Colocação simultânea do primeiro, do segundo e do terceiro dedos;

- Permanência dos dedos nas cordas ré e lá.

- Arcadas variadas em síncopas com semínimas e colcheias;

O exercício 50 apresenta a escala de ré maior ascendente, na extensão de uma oitava, com uso do primeiro, do segundo e do terceiro dedos nas cordas lá e ré.

50.

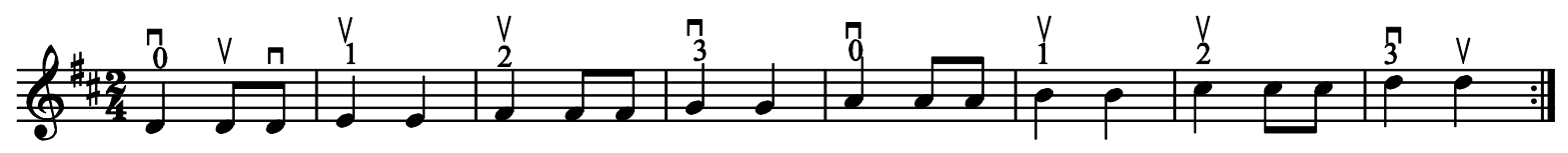


O exercício 51 apresenta a escala de ré maior ascendente e descendente, em síncopas nas figuras rítmicas de semínima e colcheia, nas cordas ré e lá. As arcadas estudadas são diferentes na escala ascendente da arcada da escala descendente.

\section{Arcadas em síncopas}

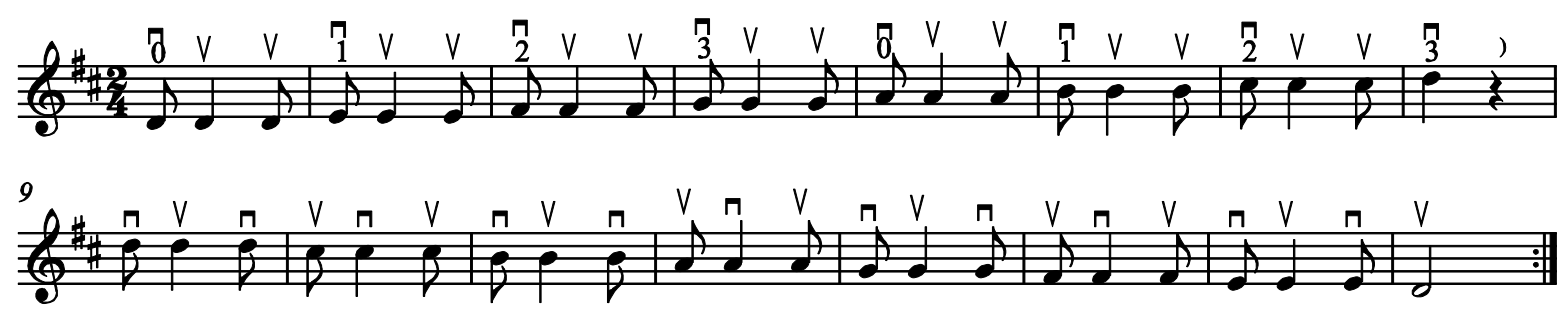

O exercício 52 apresenta a canção folclórica original Uma, duas angolinhas. A indicação de que se trata da melodia original sem alterações aparecerá sempre no título, ao lado do nome da canção folclórica que a originou.

\section{Uma, duas angolinhas - melodia original}

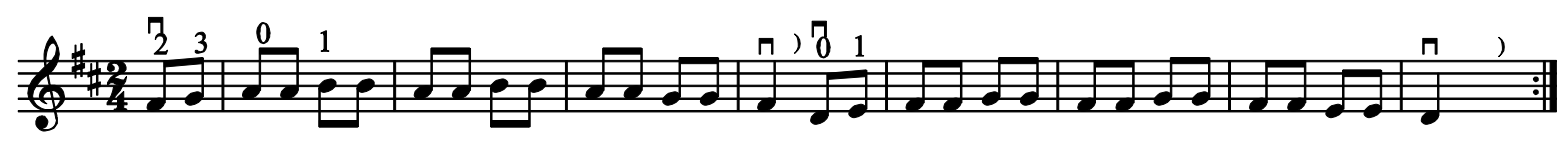

O exercício 53 apresenta a canção folclórica original Rosa amarela. O dedilhado com salto de intervalo (0-2) é utilizado aqui.

\section{Rosa amarela - melodia original}

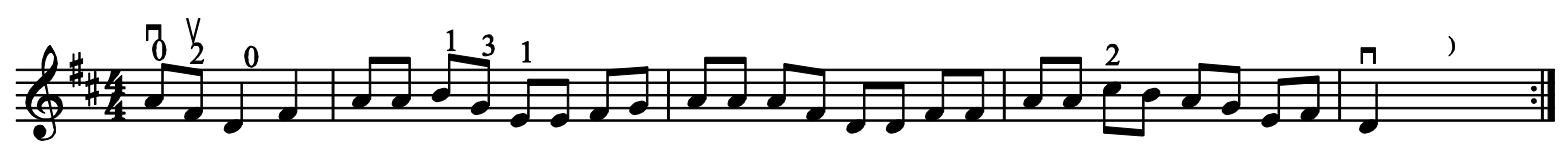

O exercício 54 apresenta a canção folclórica original $A$ canoa virou. $\mathrm{O}$ dedilhado com salto de intervalo (0-3) é utilizado aqui. Ressaltamos a importância de o aluno realizar esse dedilhado de forma que todos os três dedos abaixem e 
encontrem a corda ao mesmo tempo, e que ao colocar o terceiro dedo, o primeiro e o segundo dedos estejam em contato com a corda.

\section{A canoa virou - melodia original}

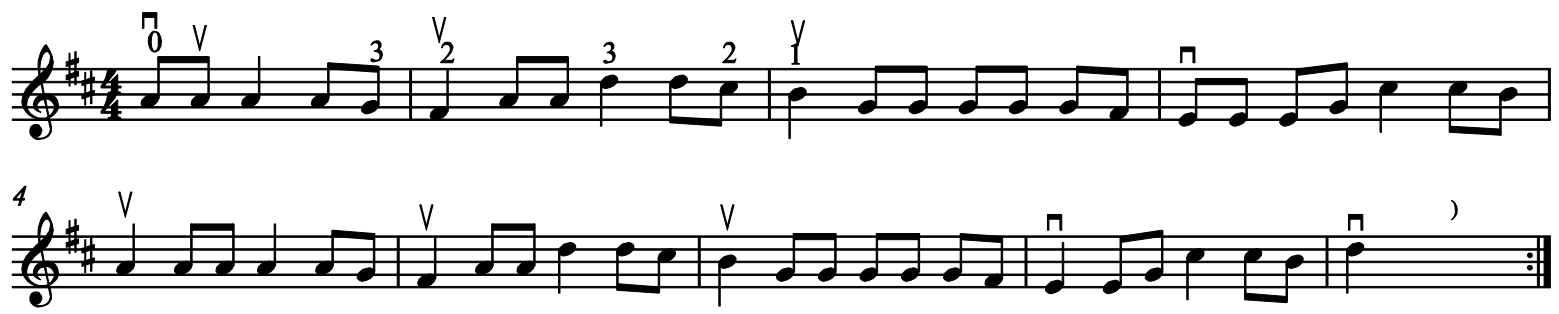

O exercício 55 apresenta a canção folclórica original O pastorzinho. O início do exercício requer o uso da arcada para cima, e o aluno deve posicionar seu arco perto da ponta, antes do início do exercício, e tocar apenas na metade superior do arco. Os três dedos da mão esquerda devem ser colocados ao mesmo tempo na corda ré logo no primeiro compasso para que o aluno possa fazer o dedilhado de tocar na corda ré solta seguida de três dedos na corda (0-3).

\section{O pastorzinho - melodia original}

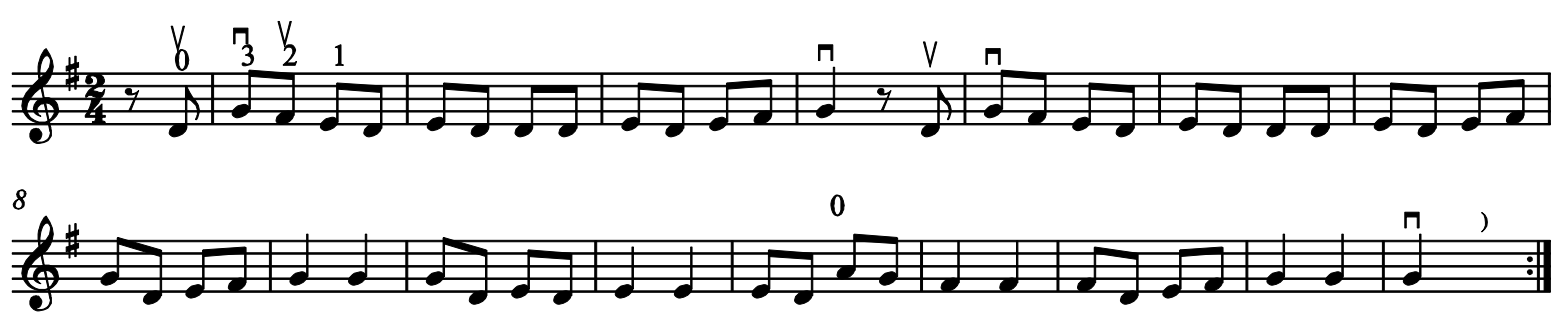

O exercício 56 apresenta a canção folclórica original $O$ pobre e o rico. Este exercício faz uso do primeiro, do segundo e do terceiro dedos na corda lá, resultando nas notas si, dó\# e ré.

56. 0 pobre e o rico - melodia original

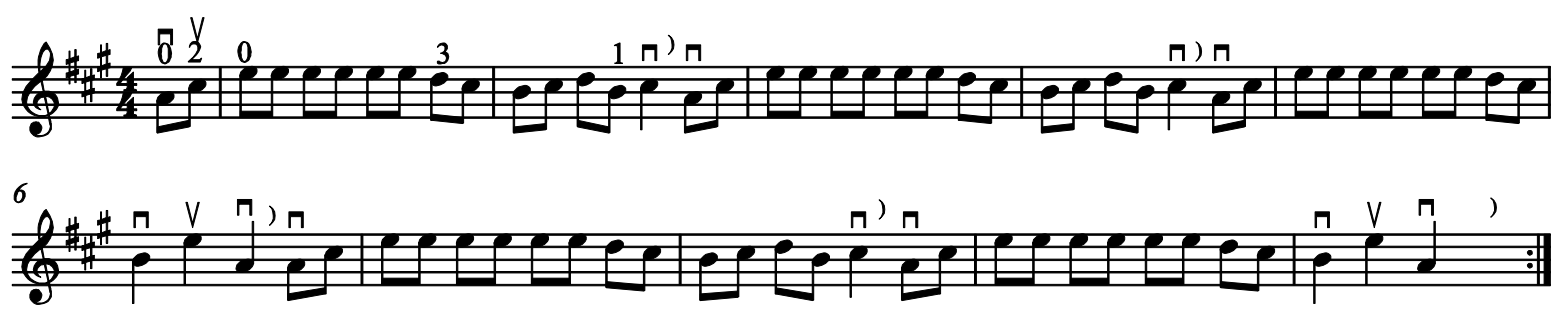


O exercício 57 apresenta a primeira linha melódica coadjuvante para a canção folclórica Pai Francisco. Há indicação de sinal de repetição apenas nos últimos cinco compassos, diferente dos exercícios anteriores que sempre repetiam do início do exercício.

\section{Pai Francisco 1}

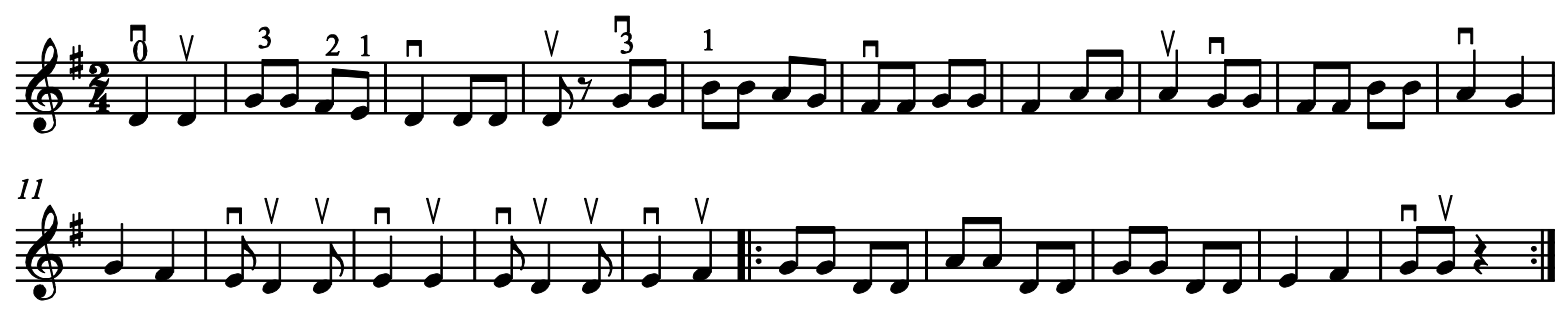

O exercício seguinte é o mesmo que o anterior, acrescido da linha do professor. A tonalidade apresentada é de sol maior.

\section{7a. Pai Francisco 1a}
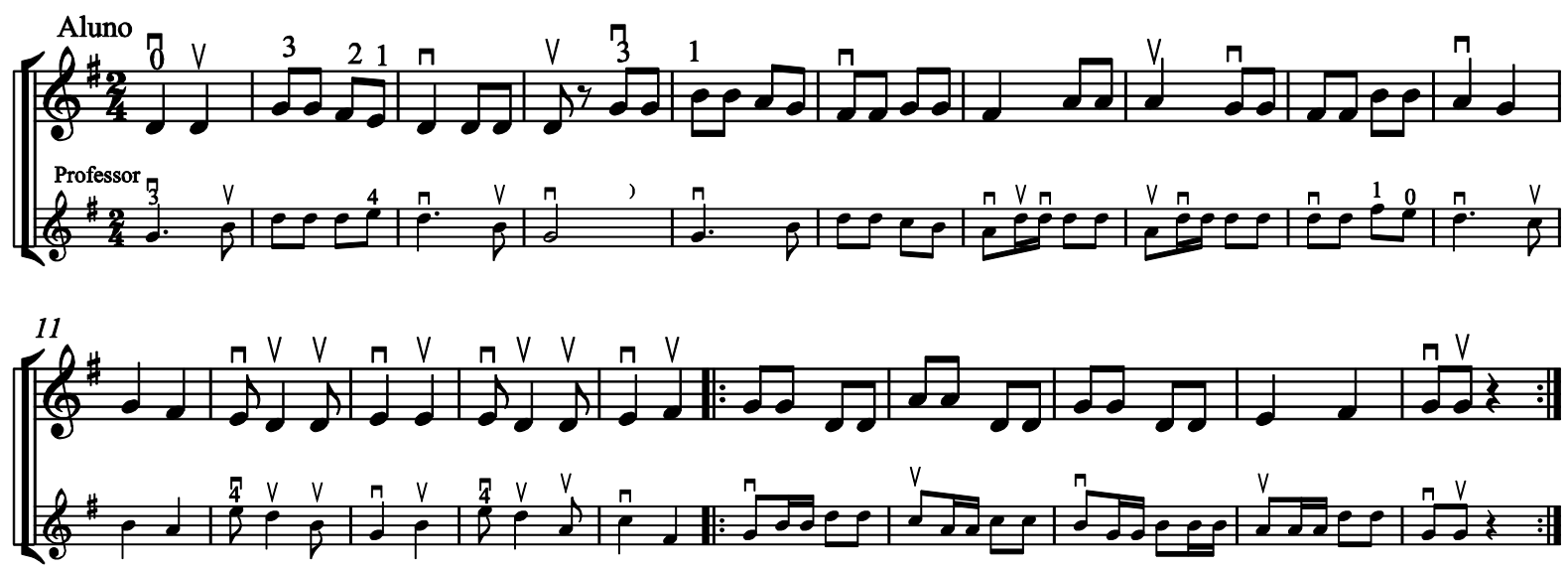

O exercício 58 apresenta a canção folclórica original Senhora dona Sancha. A linha melódica inicia-se com a nota fá\#, que exige a colocação prévia do segundo dedo na corda ré.

58. Senhora dona Sancha - melodia original

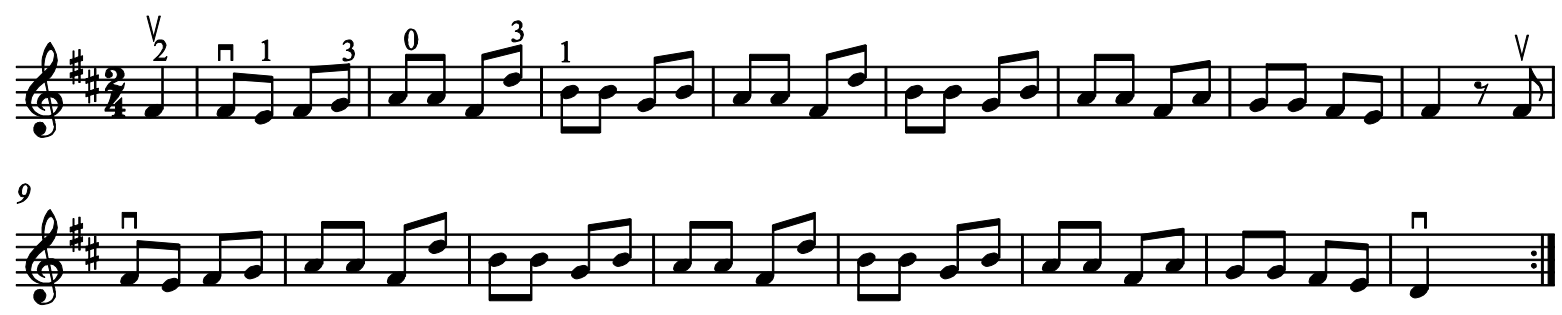


O exercício 59 apresenta a segunda linha melódica coadjuvante para a canção folclórica Pai Francisco. A linha melódica inicia-se com a nota sol dedilhada, que exige a colocação prévia do terceiro dedo na corda ré.

\section{Pai Francisco 2}
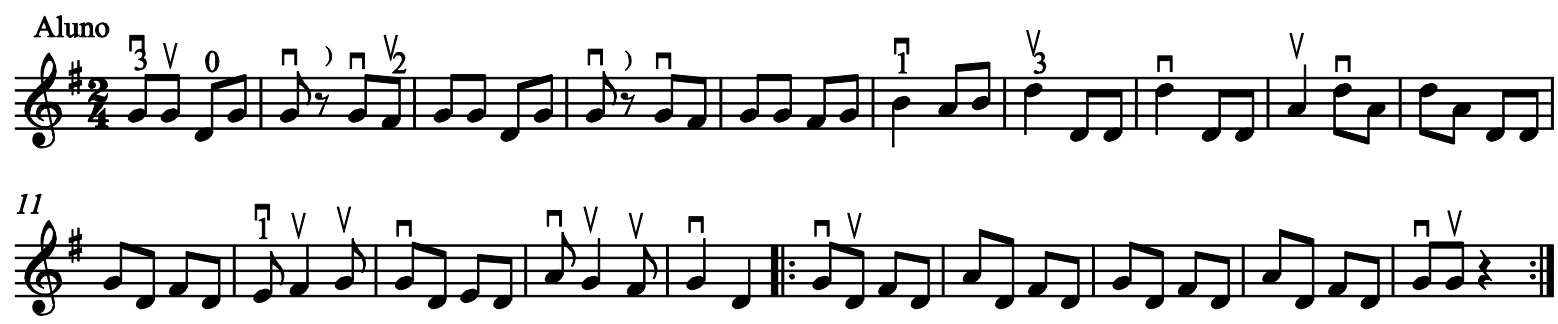

O exercício seguinte é o mesmo que o anterior, acrescido da linha do professor. A tonalidade apresentada é de sol maior.

\section{9a. Pai Francisco 2a}
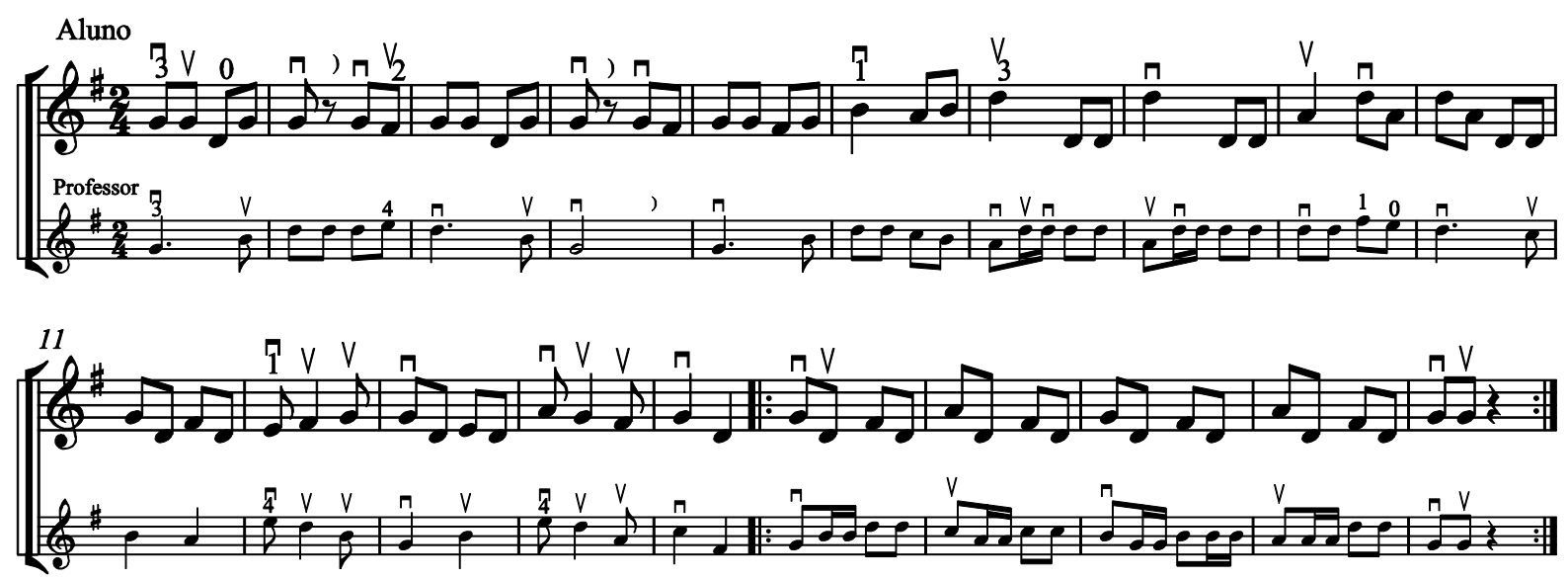

\section{Lição 6}

A lição 6 é composta por 10 exercícios, do número 60 ao 69 . O conteúdo técnico desenvolvido nesta lição segue abaixo:

- Colocação do primeiro dedo na corda sol, resultando a nota lá dedilhada, marcada com o número 1, indicativo de seu dedilhado, logo acima ou abaixo da nota;

- Arcadas em síncopas com primeiro dedo na corda sol, resultando na nota lá dedilhada; 
- Permanência do primeiro dedo na corda sol enquanto se toca na corda ré;

- Colocação do primeiro dedo na corda mi, resultando a nota fá\#, marcada com o número 1 indicativo de seu dedilhado, logo acima ou abaixo da nota;

- Arpejos de ré maior, sol maior e lá maior.

A partir da lição 6, os pizzicatos de mão esquerda somente aparecerão em alguns exercícios técnicos da lição para servir de lembrete ao aluno da postura de sua mão esquerda. Aos poucos, durante o método, esse recurso deixará de ser empregado, pois se supõe que o aluno já terá se acostumado com a posição correta da mão no violino.

O exercício 60 apresenta a colocação do primeiro dedo na corda sol, resultando na nota lá dedilhada, marcada com o número 1, indicativo de seu dedilhado.

\section{Primeiro dedo na corda Sol}

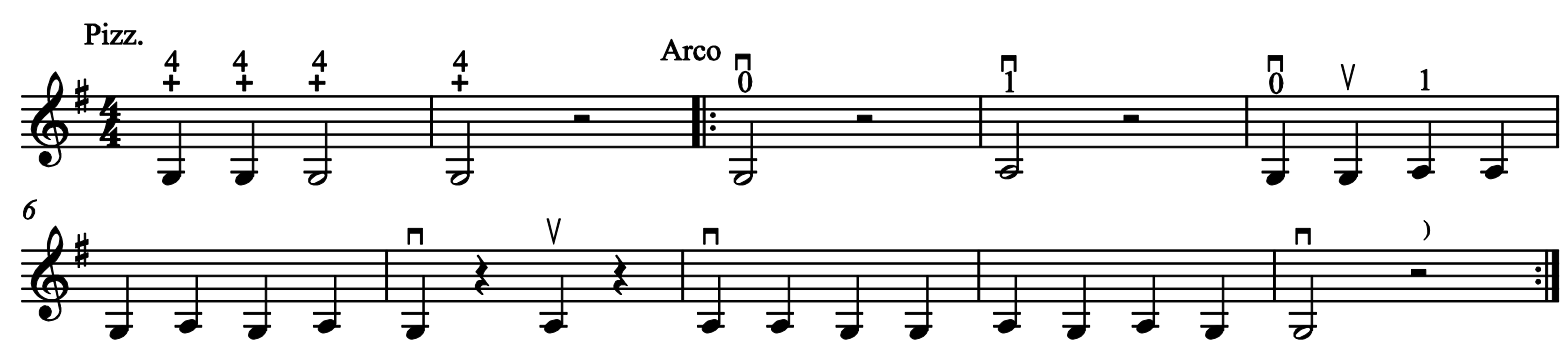

O exercício 61 apresenta a segunda linha melódica coadjuvante para a canção folclórica Bambalalão, com uso do primeiro dedo na corda sol, resultando na nota lá dedilhada.

\section{Bambalalão 2}
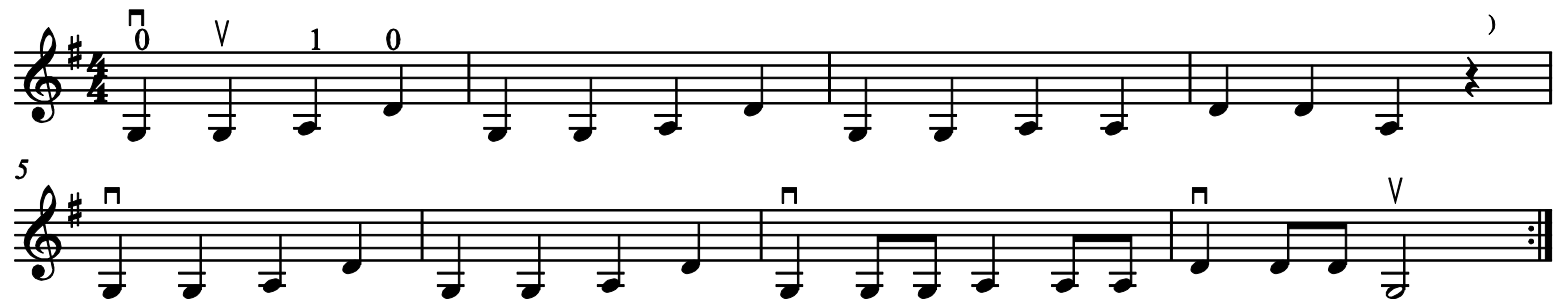
O exercício seguinte é o mesmo que o anterior, acrescido da linha do professor. A tonalidade apresentada é de sol maior.

\section{1a. Bambalalão 2a}
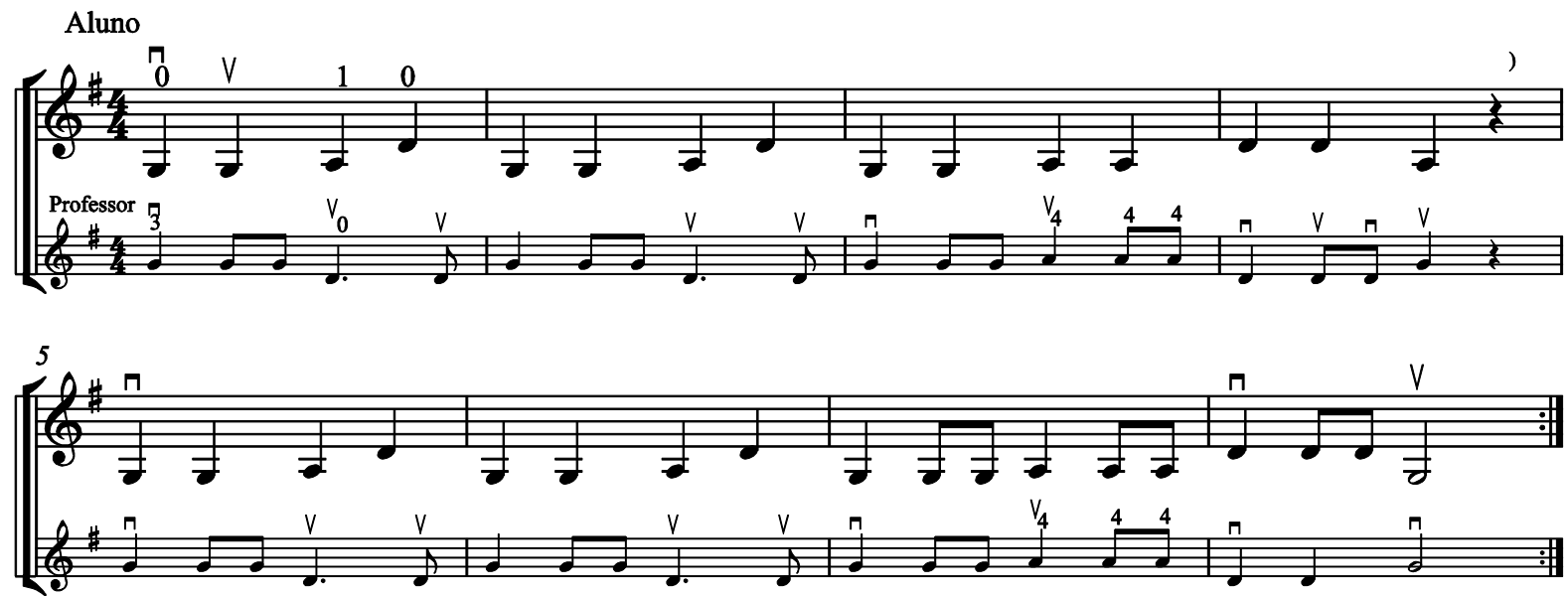

O exercício 62 apresenta uso do primeiro dedo na corda sol com colcheias.

62.

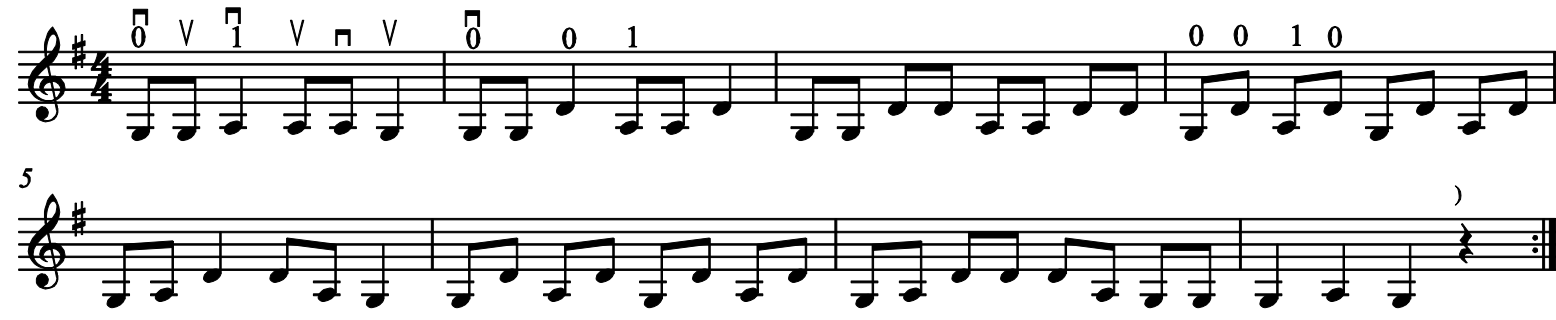

O exercício 63 apresenta uso de arcadas variadas nas cordas ré e sol em síncopas e ritmos em colcheias.

\section{Arcadas}
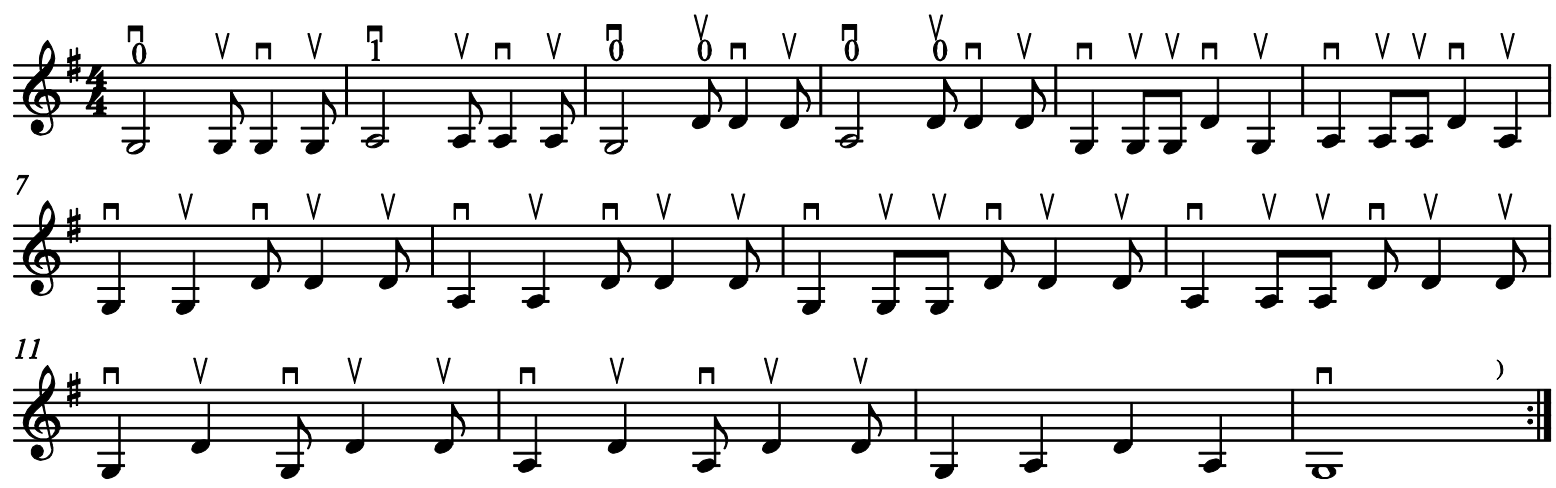
O exercício 64 apresenta como elemento técnico relevante a permanência do primeiro dedo na corda sol enquanto se toca na corda ré. O primeiro dedo deve permanecer na corda até que se termine o traço indicativo, escrito ao lado do dedilhado.

\section{Permanência do primeiro dedo}

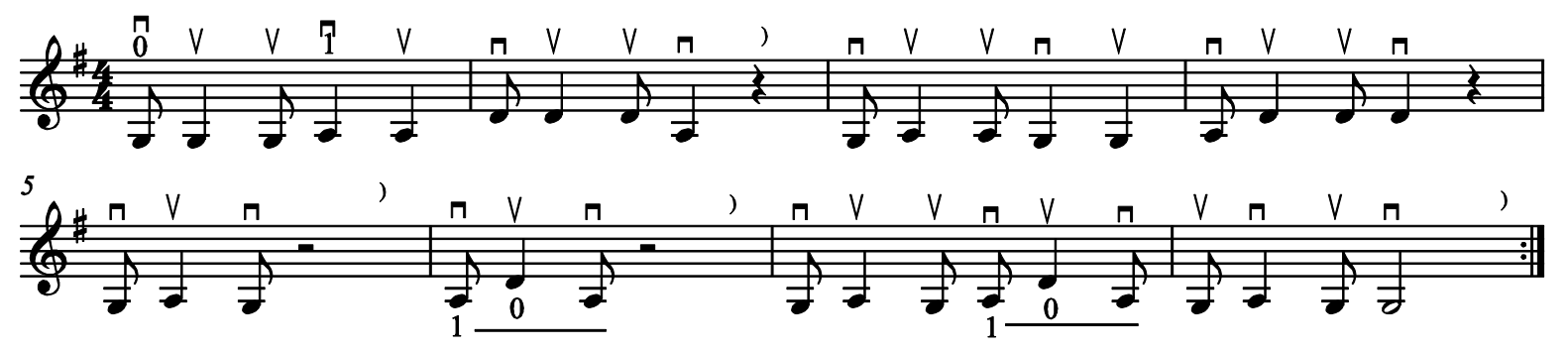

O exercício 65 apresenta a colocação do primeiro dedo na corda mi, resultando na nota fá\#.

\section{Primeiro dedo na corda $\mathrm{Mi}$}
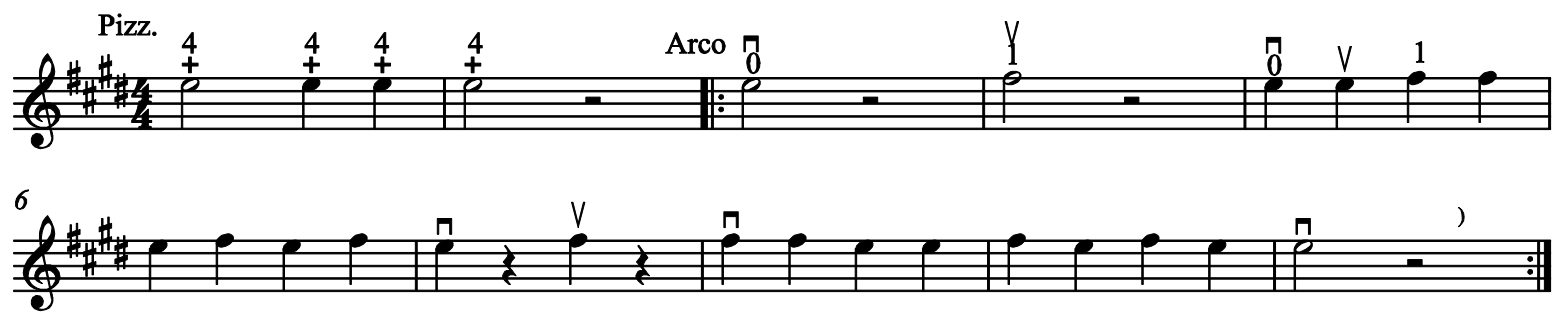

O exercício 66 apresenta o uso do primeiro dedo na corda mi, resultando na nota fá\#. A troca de cordas entre a corda mi e a lá deve ser realizada com a mão direita posicionada em um ângulo mais próximo possível da outra corda, para obter um toque suave na troca entre as cordas.

66.
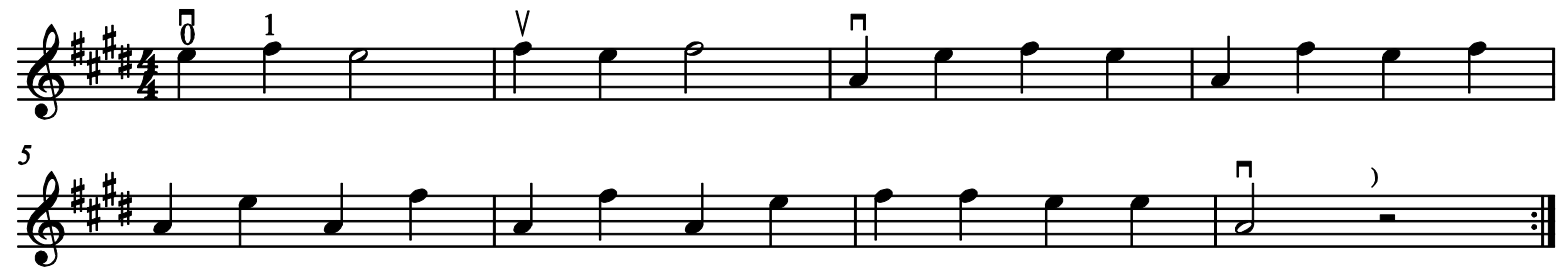
O exercício 67 apresenta a primeira linha melódica coadjuvante para a canção folclórica Lá na ponte da Vinhaça, com uso do primeiro dedo na corda mi, resultando na nota fá\#, marcada com o número 1 , indicativo de seu dedilhado.

\section{Lá na ponte da Vinhaça 1}

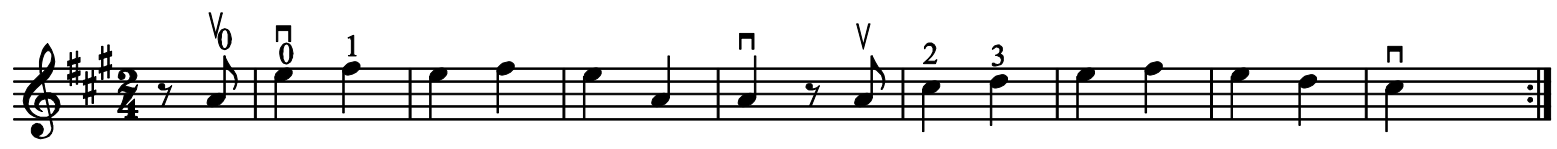

O exercício seguinte é o mesmo que o anterior, acrescido da linha do professor. A tonalidade apresentada é de lá maior.

\section{7a. Lá na ponte da Vinhaça 1a}

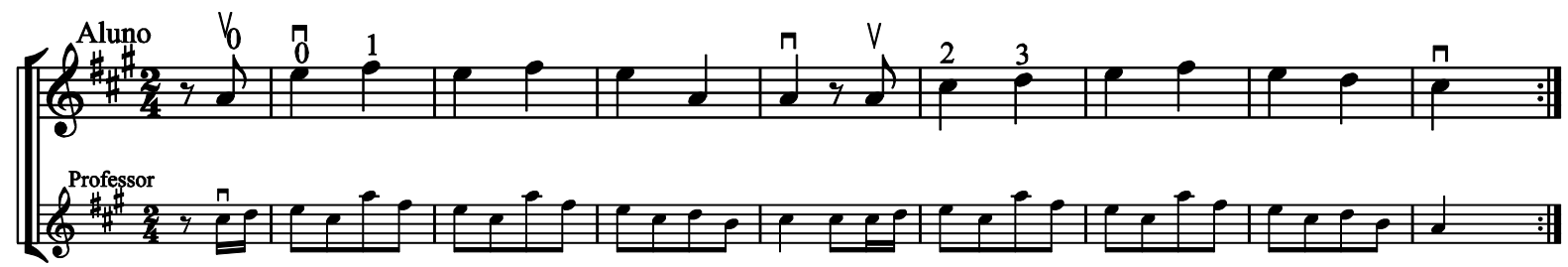

O exercício 68 apresenta a segunda linha melódica coadjuvante para a canção folclórica Lá na ponte da Vinhaça, com uso do primeiro dedo na corda sol, resultando na nota lá, marcada com o número 1, indicativo de seu dedilhado.

\section{Lá na ponte da Vinhaça 2}

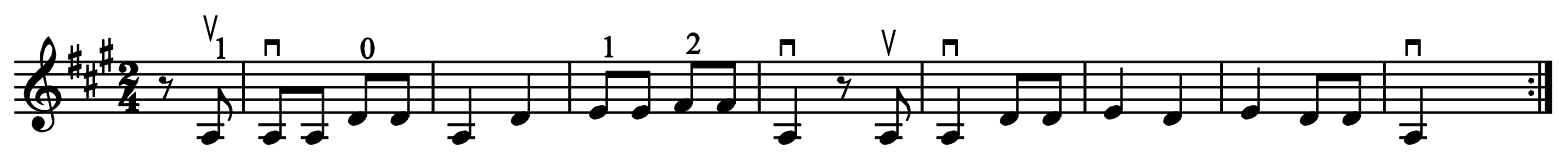

O exercício seguinte é o mesmo que o anterior, acrescido da linha do professor. A tonalidade apresentada é de lá maior.

\section{8a. Lá na ponte da Vinhaça $2 a$}

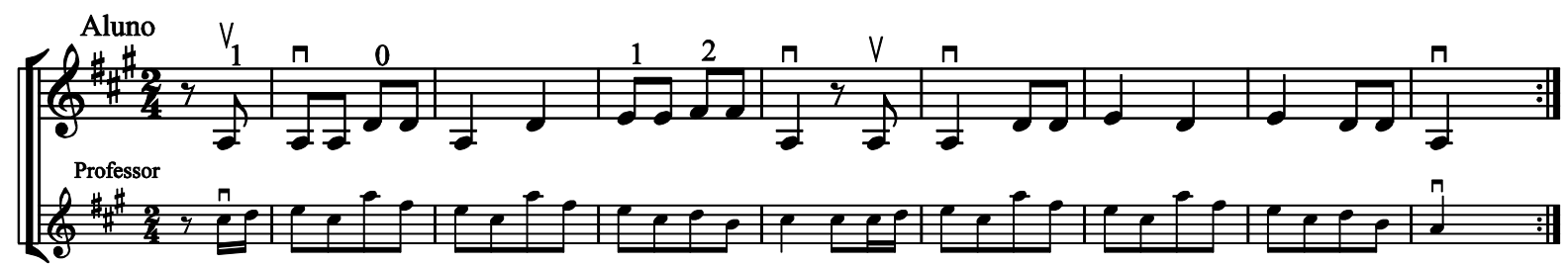


O exercício 69 apresenta arpejos em ré maior, sol maior e lá maior, com uso dos dedilhados apresentados até o momento.

\section{Arpejos}

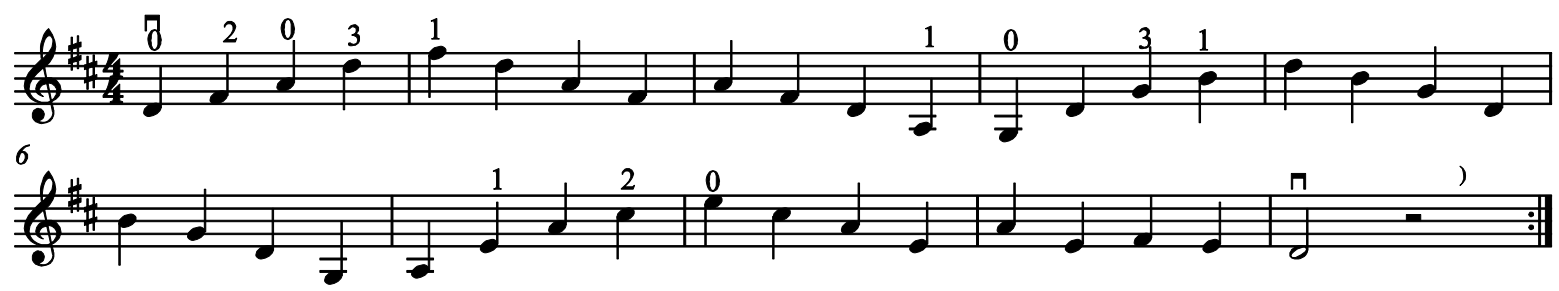

\section{Lição 7}

A lição 7 é composta por 10 exercícios, do número 70 ao 79 . O conteúdo técnico desenvolvido nesta lição segue abaixo:

- Colocação do segundo dedo na corda sol, resultando na nota si, marcada com o número 2, indicativo de seu dedilhado, logo acima ou abaixo da nota;

- Colocação do segundo dedo na corda mi, resultando na nota sol\#, marcada com o número 2 indicativo de seu dedilhado, logo acima ou abaixo da nota;

- Escala com salto de terças, nas cordas mi e sol.

O exercício 70 apresenta a colocação do segundo dedo na corda sol, resultando na nota si, marcada com o número 2 , indicativo de seu dedilhado.

\section{Segundo dedo na corda Sol}

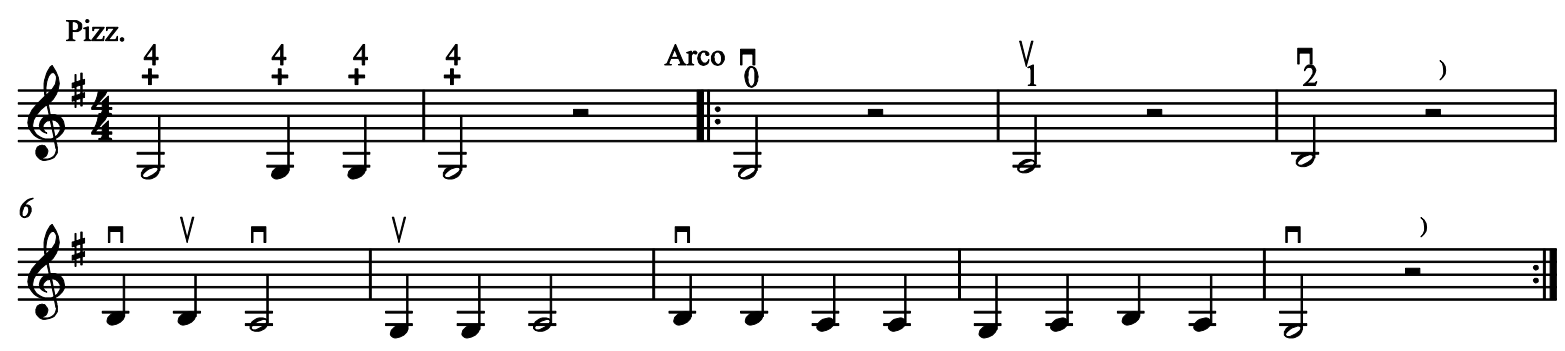


O exercício 71 apresenta o uso do primeiro e segundo dedos na corda sol, resultando nas notas lá e si.

71.
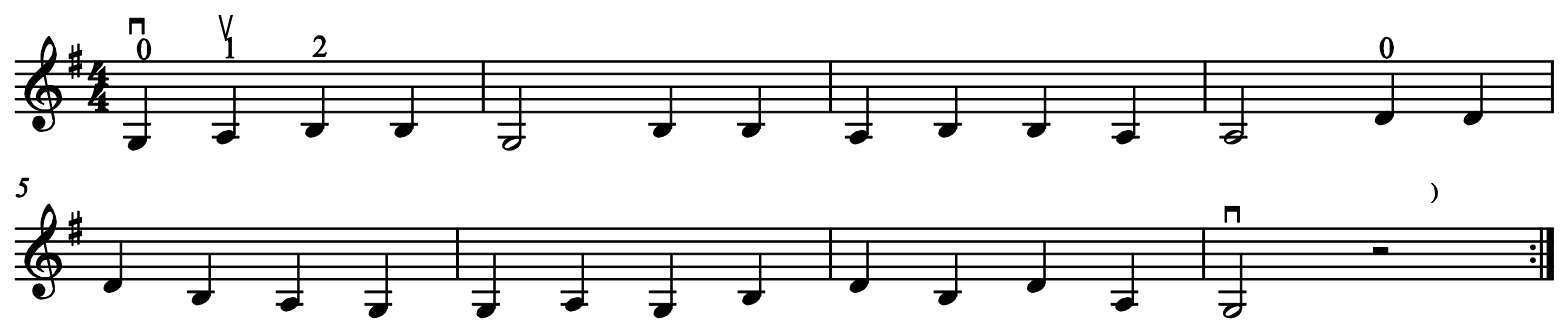

O exercício 72 apresenta a primeira linha melódica coadjuvante para a canção folclórica Terezinha de Jesus, com uso do segundo dedo na corda sol, resultando na nota si, marcada com o número 2 , indicativo de seu dedilhado. O exercício inicia-se com o arco na ponta.

\section{Terezinha de Jesus 1}

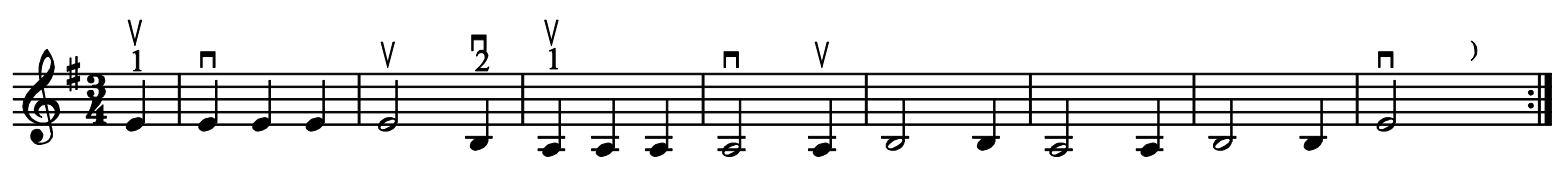

O exercício seguinte é o mesmo que o anterior, acrescido da linha do professor. A tonalidade apresentada é de sol maior.

\section{2a. Terezinha de Jesus 1a}

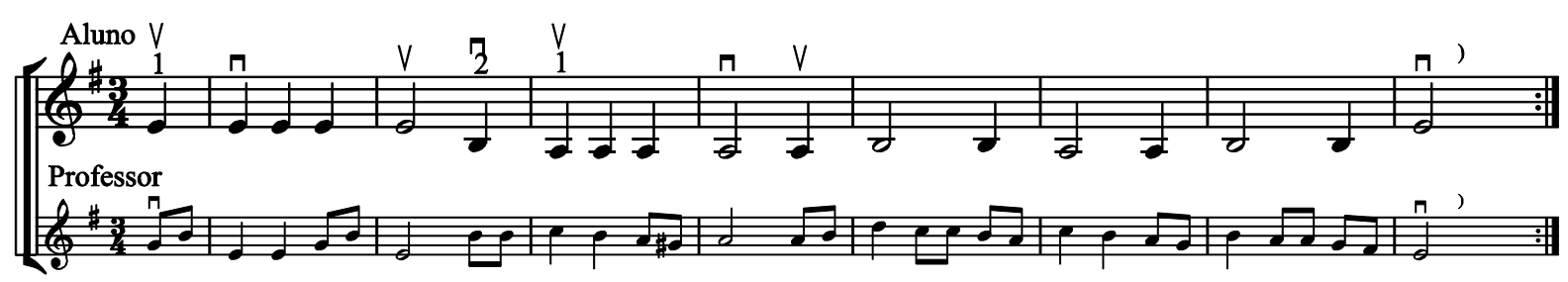


O exercício 73 apresenta a segunda linha melódica coadjuvante para a canção folclórica Terezinha de Jesus, com uso do segundo dedo na corda sol, resultando na nota si, marcada com o número 2 , indicativo de seu dedilhado.

\section{Hei de namorar 2}

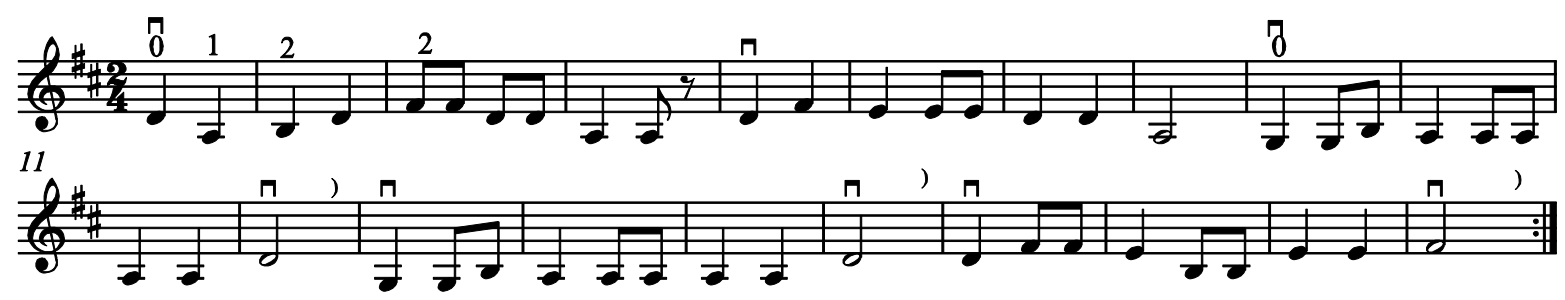

O exercício seguinte é o mesmo que o anterior, acrescido da linha do professor. A tonalidade apresentada é de ré maior.

\section{3a. Hei de namorar $2 a$}
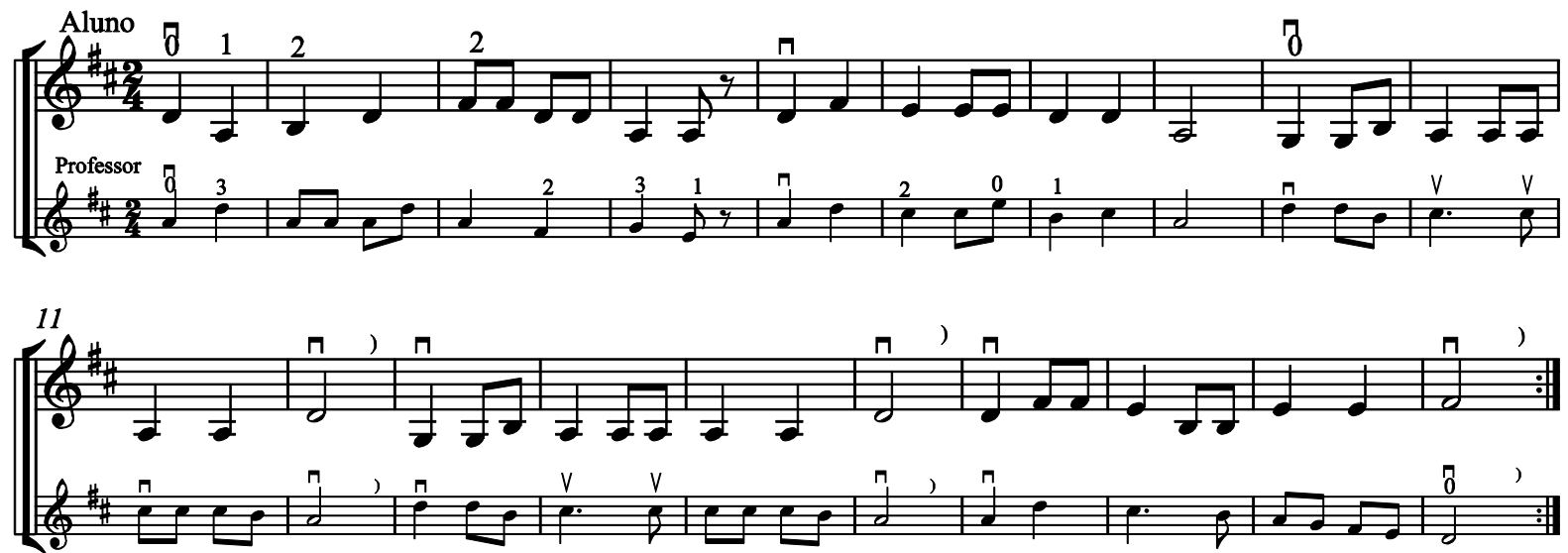

O exercício 74 apresenta a segunda linha melódica coadjuvante para a canção folclórica Sinhá Aninha, com uso do segundo dedo na corda sol, resultando na nota si.

\section{Sinhá Aninha 2}
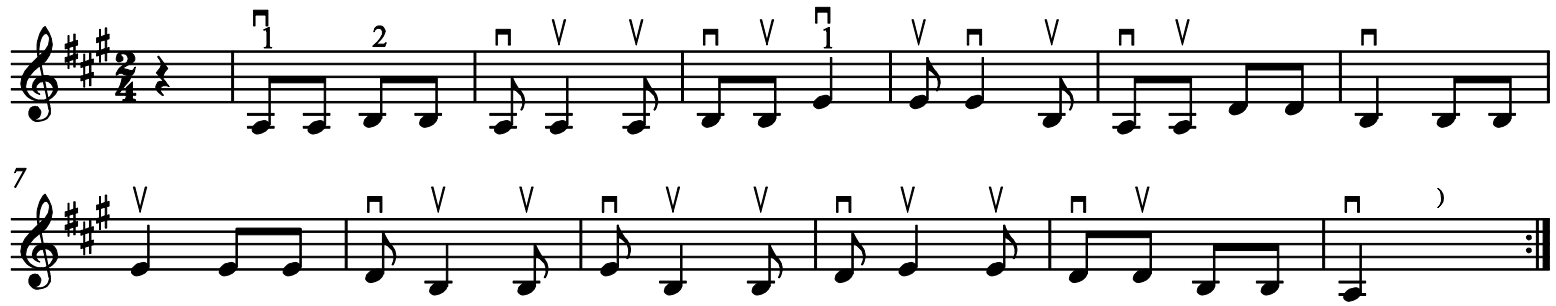
O exercício seguinte é o mesmo que o anterior, acrescido da linha do professor. A tonalidade apresentada é de lá maior.

\section{4a. Sinhá Aninha 2a}
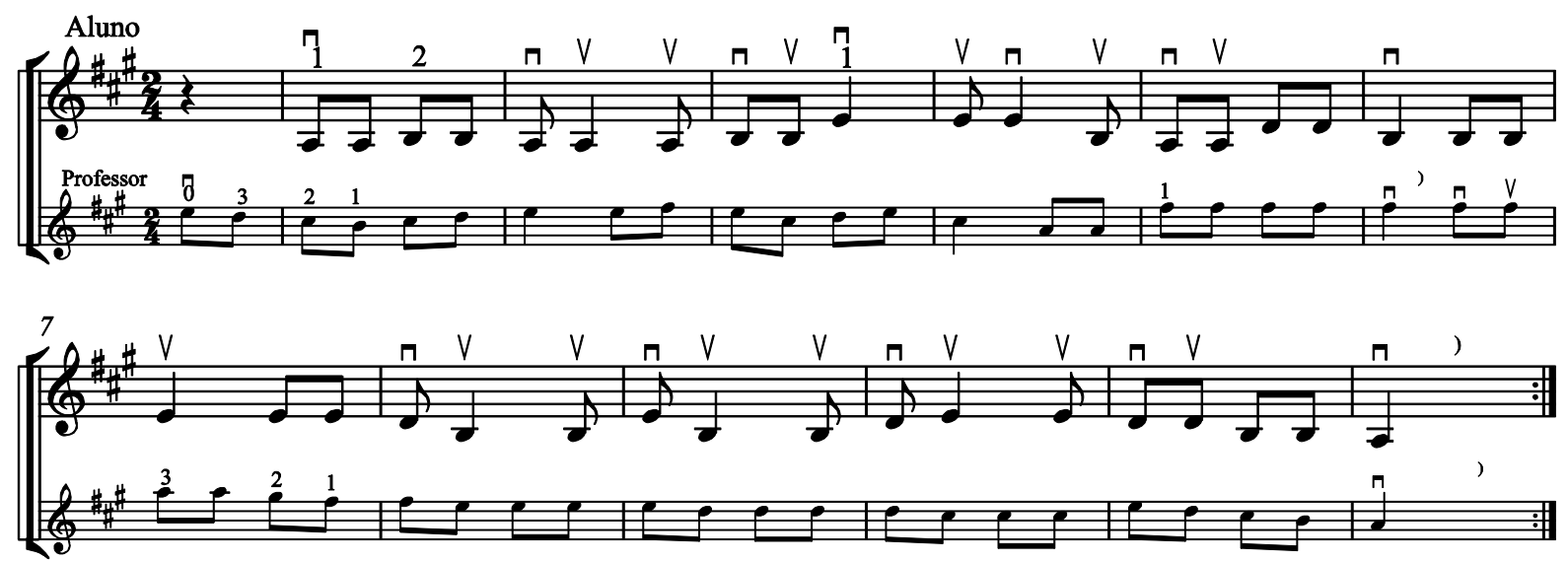

O exercício 75 apresenta a colocação do segundo dedo na corda $m i$, resultando na nota sol\#, marcada com o número 2, indicativo de seu dedilhado.

\section{Segundo dedo na corda $\mathrm{Mi}$}
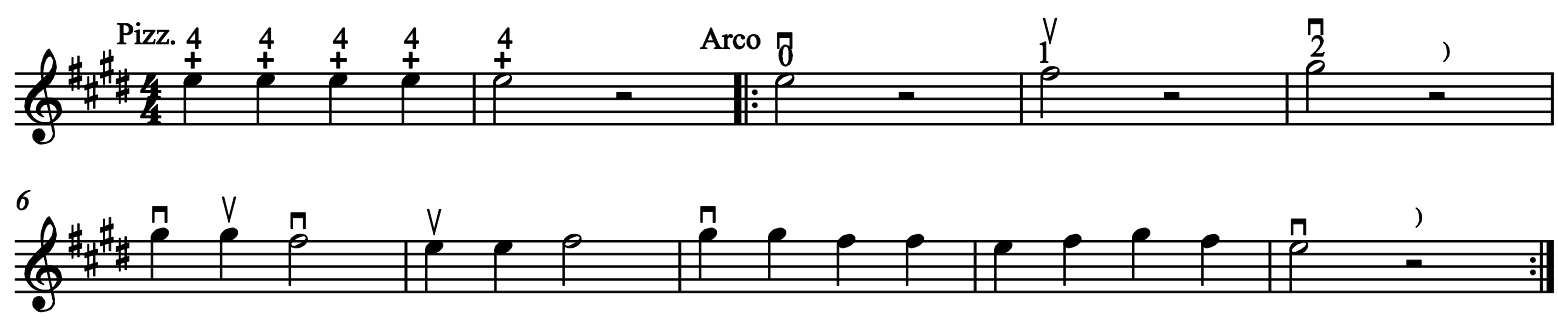

O exercício 76 apresenta uma escala de lá maior com uso de dedilhado já apresentado anteriormente.

76.
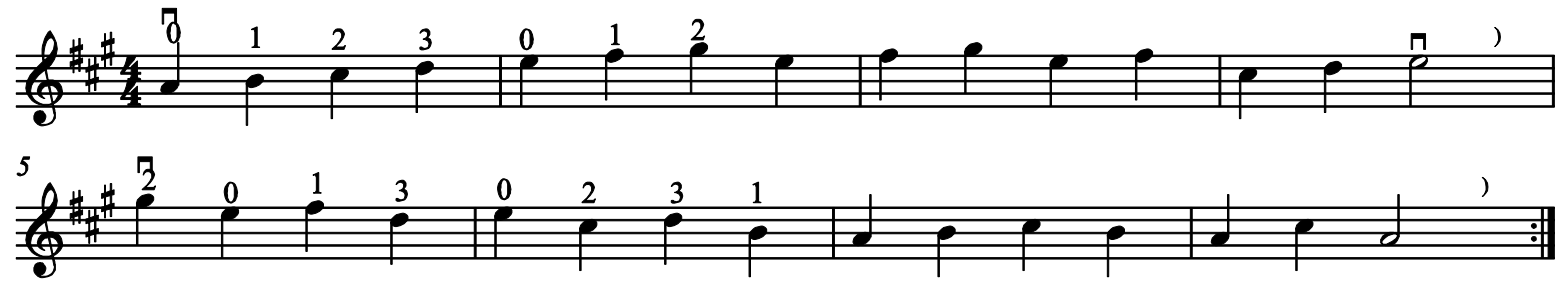
O exercício 77 apresenta a primeira linha melódica coadjuvante para a canção folclórica $A$ pombinha voou, com uso do segundo dedo na corda mi, resultando na nota sol\#, marcada com o número 2 , indicativo de seu dedilhado.

\section{A pombinha voou 1}

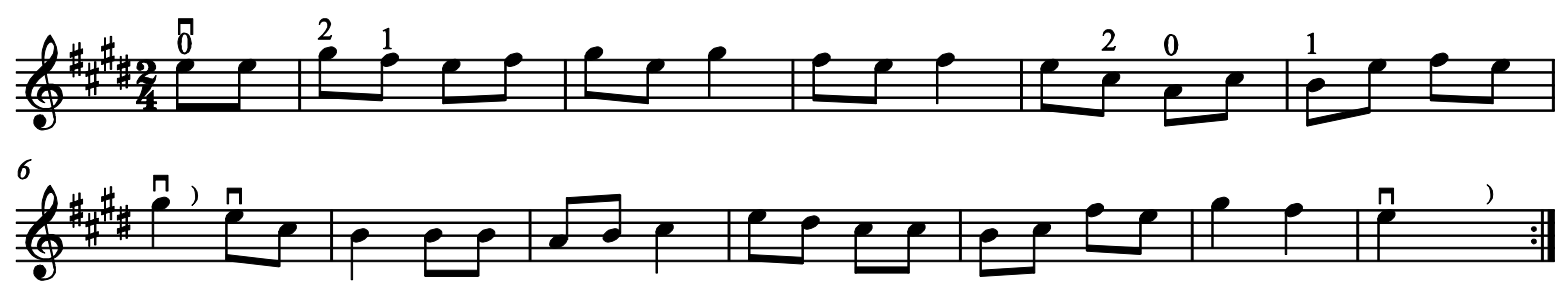

O exercício seguinte é o mesmo que o anterior, acrescido da linha do professor. A tonalidade apresentada é de mi maior.

\section{7a. A pombinha voou 1a}
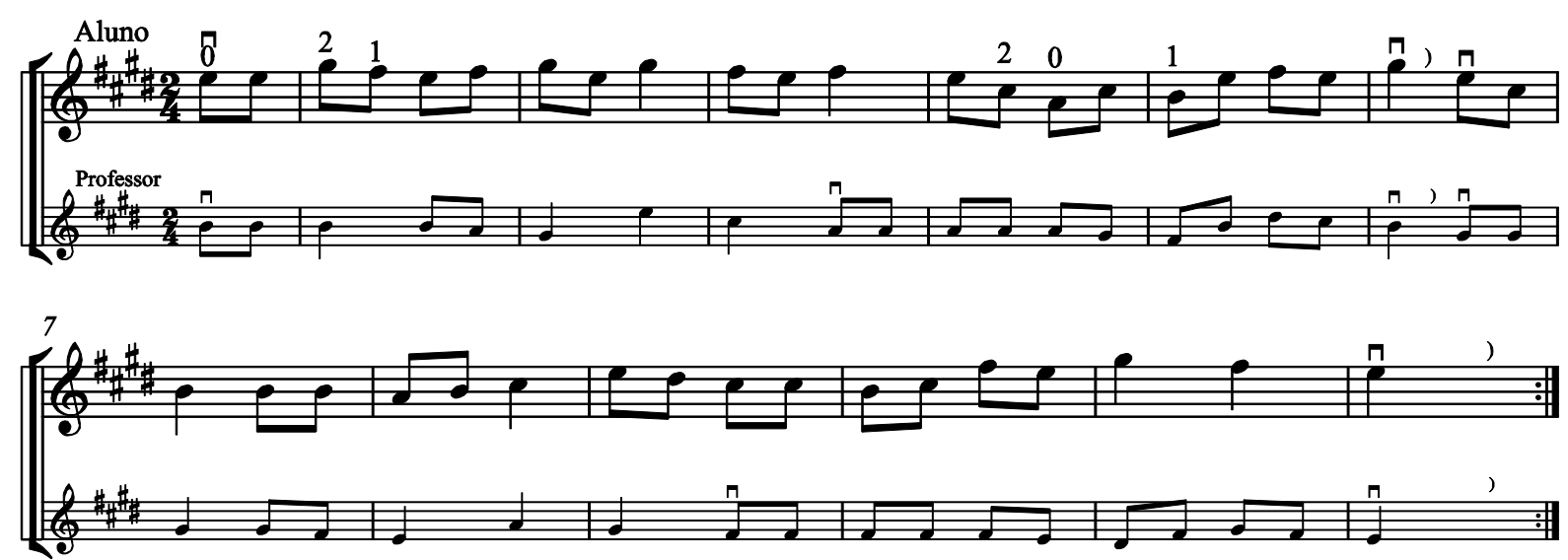

O exercício 78 apresenta a canção folclórica original Passarás, não passarás.

78. Passarás, não passarás - melodia original

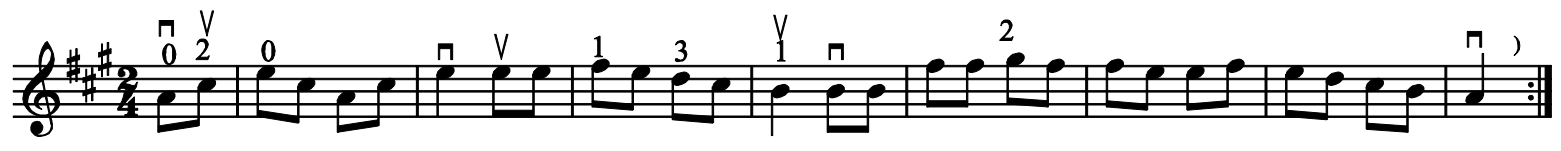


O exercício 79 apresenta uso de saltos em intervalos nas quatro cordas com uso do dedilhado apresentado anteriormente.

79.

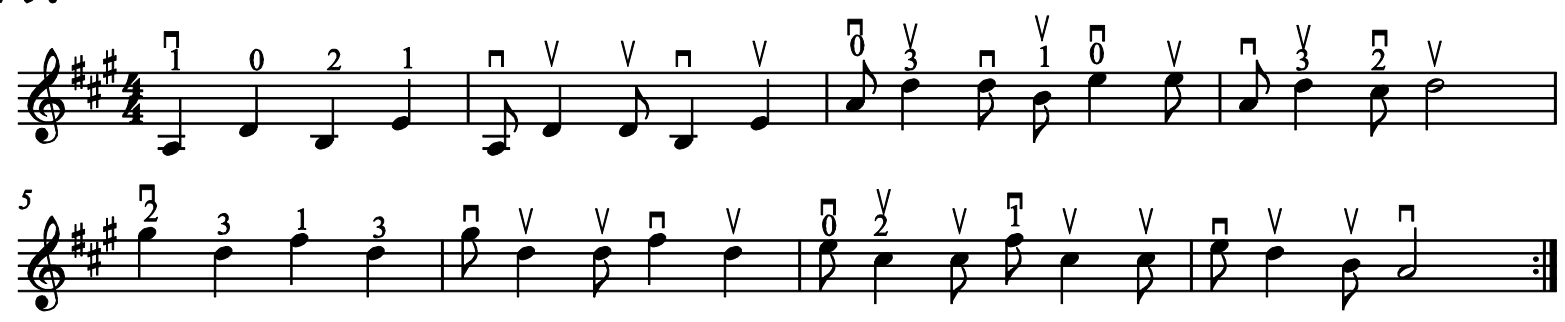

Lição 8

A lição 8 é composta por 10 exercícios, do número 80 ao 89 . O conteúdo técnico desenvolvido nesta lição segue abaixo:

- Colocação do terceiro dedo na corda sol, resultando na nota dó, marcada com o número 3 , indicativo de seu dedilhado, logo acima ou abaixo da nota;

- Acento musical;

- Colocação do terceiro dedo na corda mi, resultando na nota lá, marcada com o número 3, indicativo de seu dedilhado, logo acima ou abaixo da nota;

- Ponto de aumento em mínima.

O exercício 80 apresenta a colocação do terceiro dedo na corda sol, resultando na nota dó, marcada com o número 3 indicando o seu dedilhado.

\section{Terceiro dedo na corda Sol}

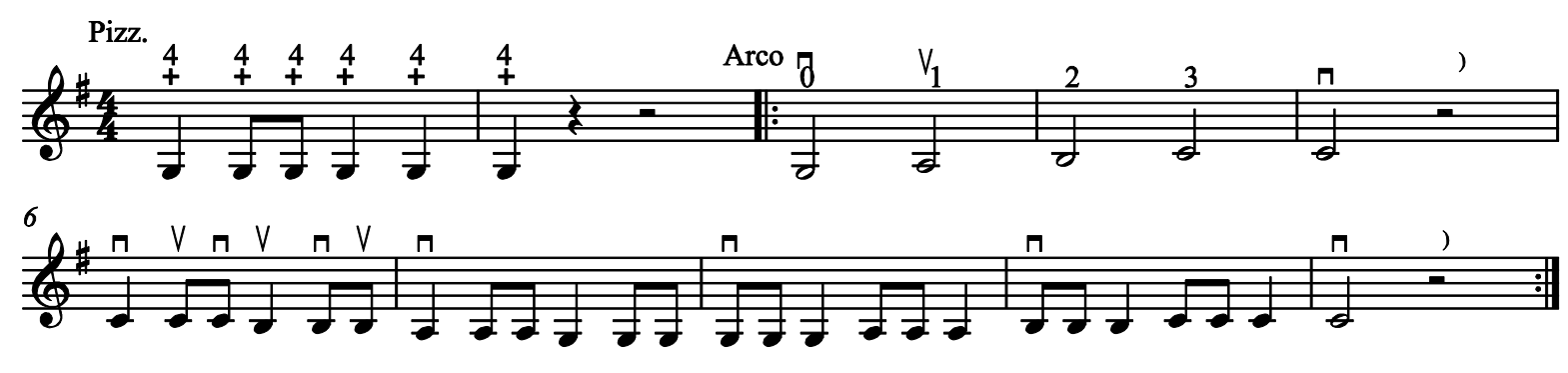


O exercício 81 apresenta o acento musical. Esse acento deve ser executado com o arco inteiro, apoiando-se com maior peso e velocidade na partida da nota, e imediatamente reduzindo tanto o peso como a velocidade do braço direito.

\section{Acento musical}

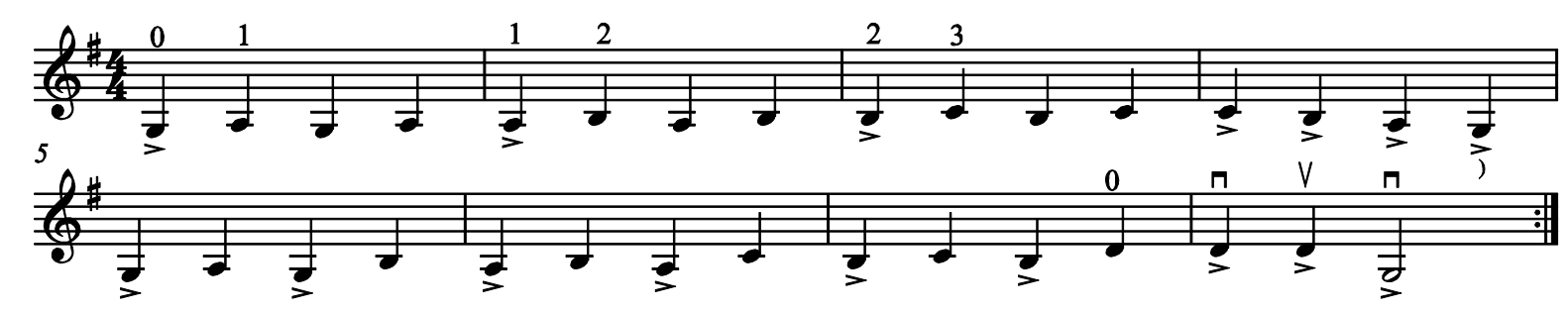

O exercício 82 apresenta a primeira linha melódica coadjuvante para a canção folclórica A cantiga de ninar, com uso do terceiro dedo na corda sol, resultando na nota dó, marcada com o número 3 , indicativo de seu dedilhado.

\section{A cantiga de ninar 1}

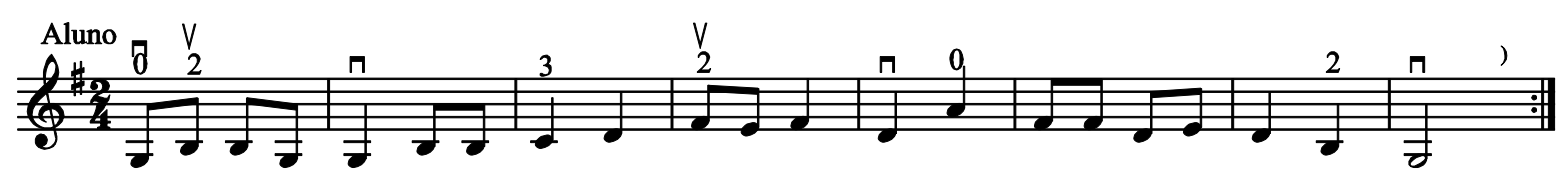

O exercício seguinte é o mesmo que o anterior, acrescido da linha do professor. A tonalidade apresentada é de sol maior.

\section{2a. A cantiga de ninar $1 \mathrm{a}$}

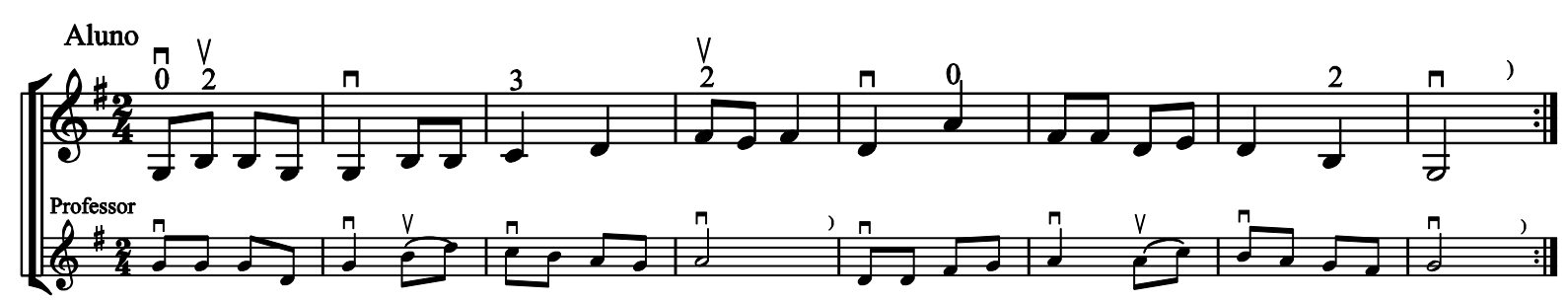


O exercício 83 apresenta a primeira linha melódica coadjuvante para a canção folclórica Os escravos de Job, com uso do terceiro dedo na corda sol, resultando na nota dó.

\section{Os escravos de Job 1}

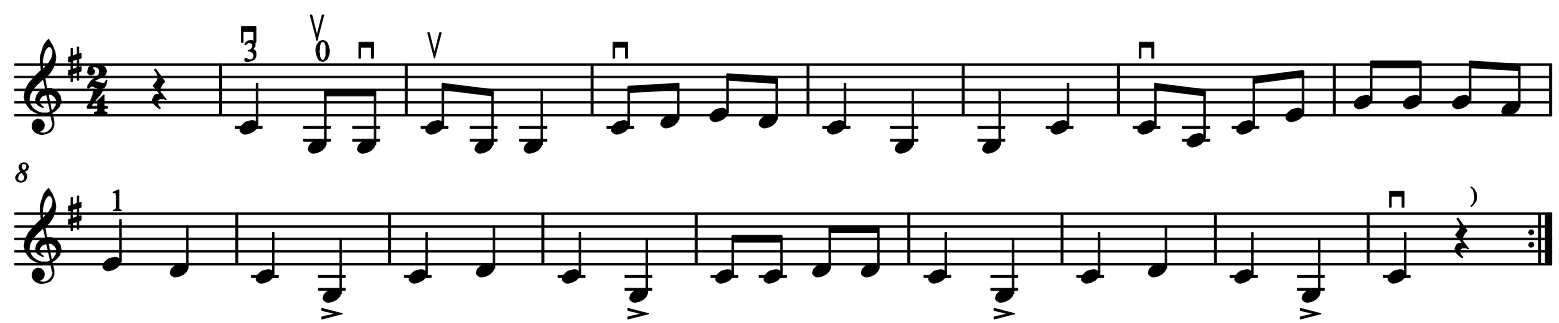

O exercício seguinte é o mesmo que o anterior, acrescido da linha do professor. A tonalidade apresentada é de sol maior.

\section{3a. Os escravos de Job 1a}
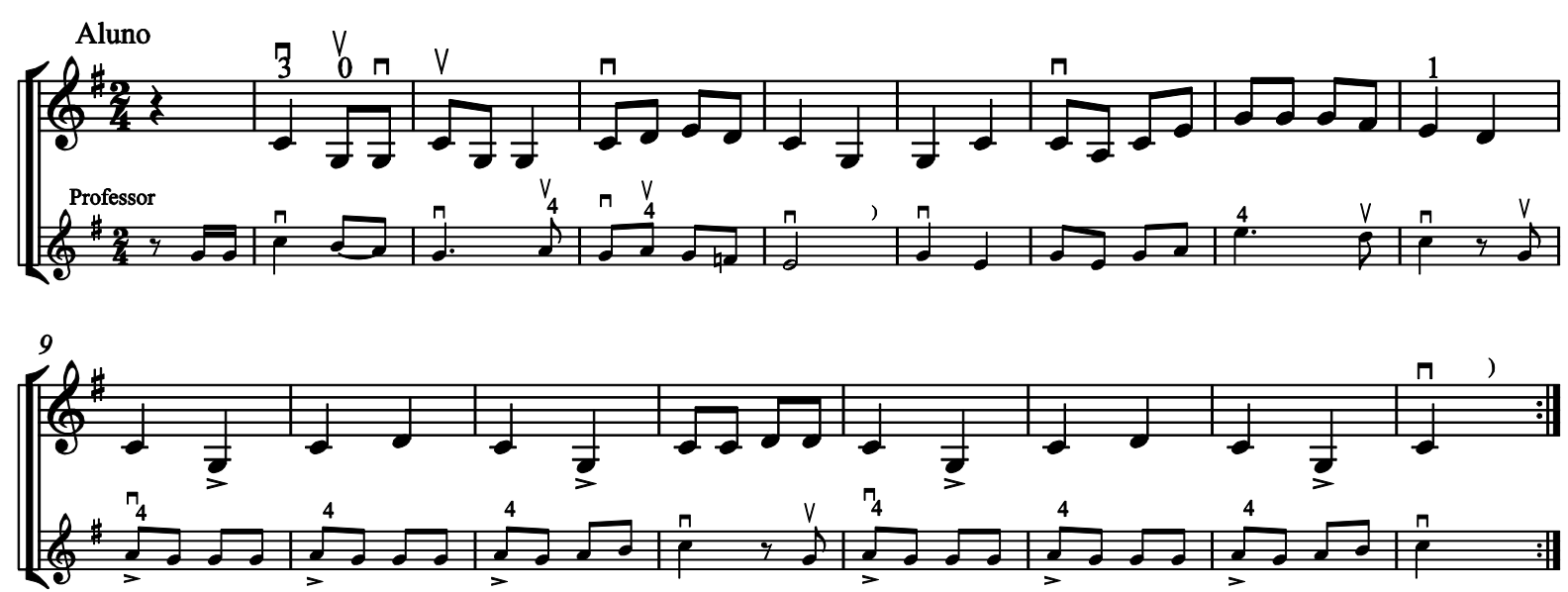

O exercício 84 apresenta a primeira linha melódica coadjuvante para a canção folclórica $O$ pastorzinho, com uso do terceiro dedo na corda sol resultando na nota dó. As colcheias são utilizadas em contratempo, com acento musical nas semínimas.

\section{0 pastorzinho 1}

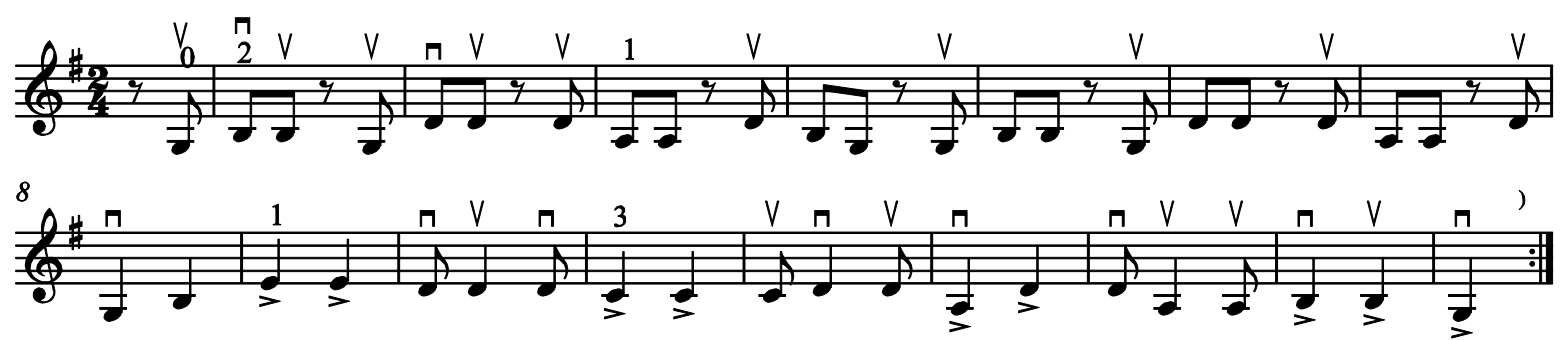


O exercício seguinte é o mesmo que o anterior, acrescido da linha do professor. A tonalidade apresentada é de sol maior.

\section{4a. 0 pastorzinho 1a}
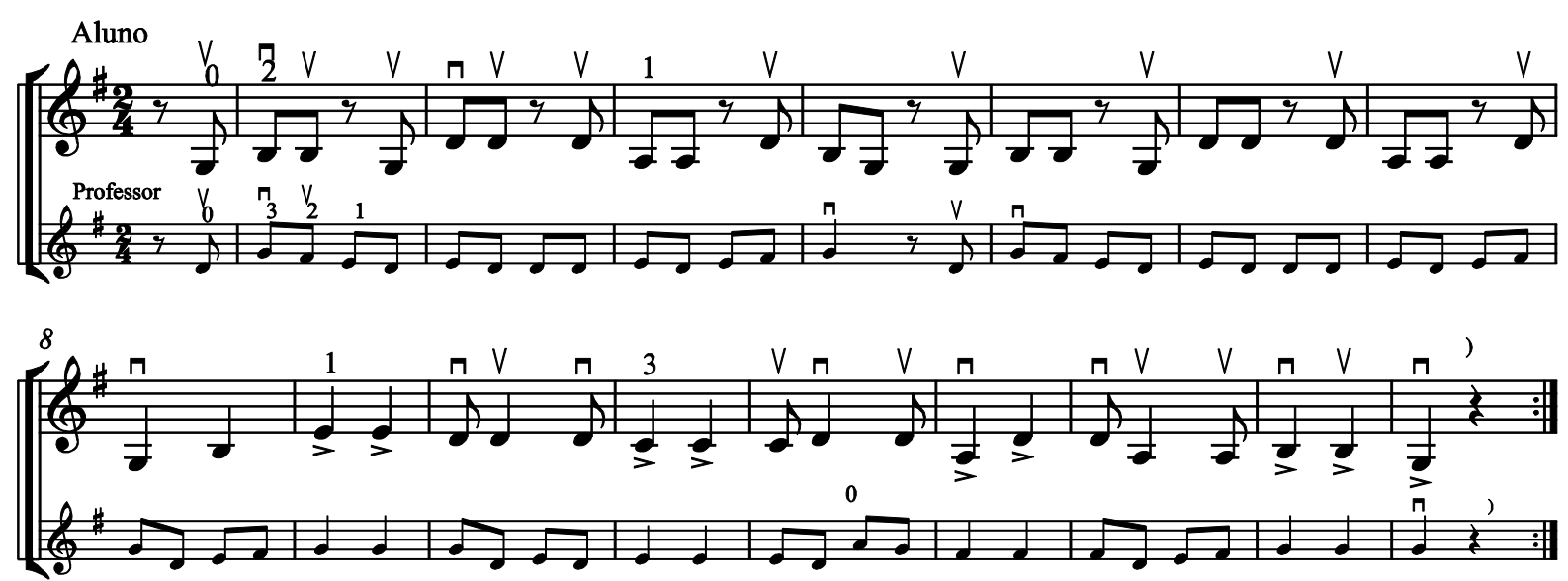

O exercício 85 apresenta a colocação do terceiro dedo na corda mi, resultando na nota lá dedilhada, recebendo o número 3 , indicativo de seu dedilhado, logo acima ou abaixo da nota.

\section{Terceiro dedo na corda Mi}
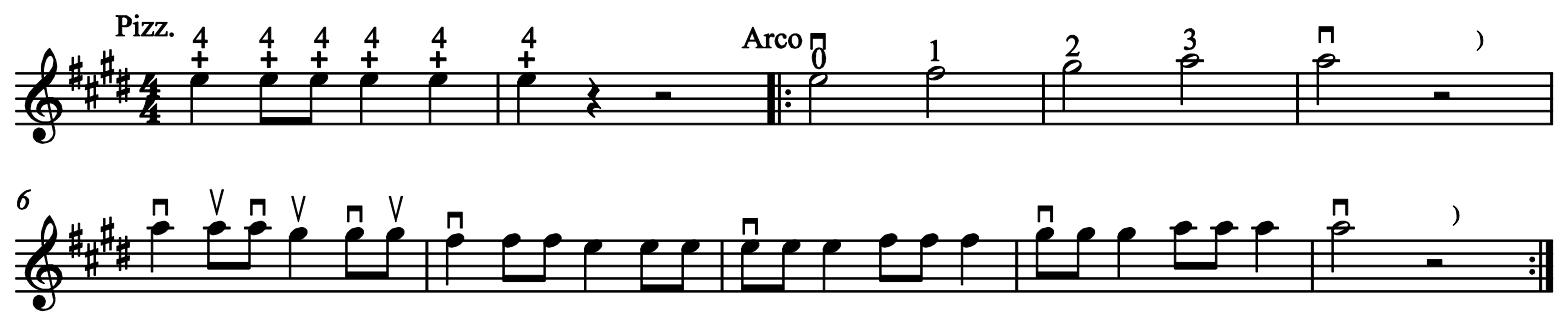

O exercício 86 apresenta a canção folclórica original Sinhá Aninha.

86. Sinhá Aninha - melodia original
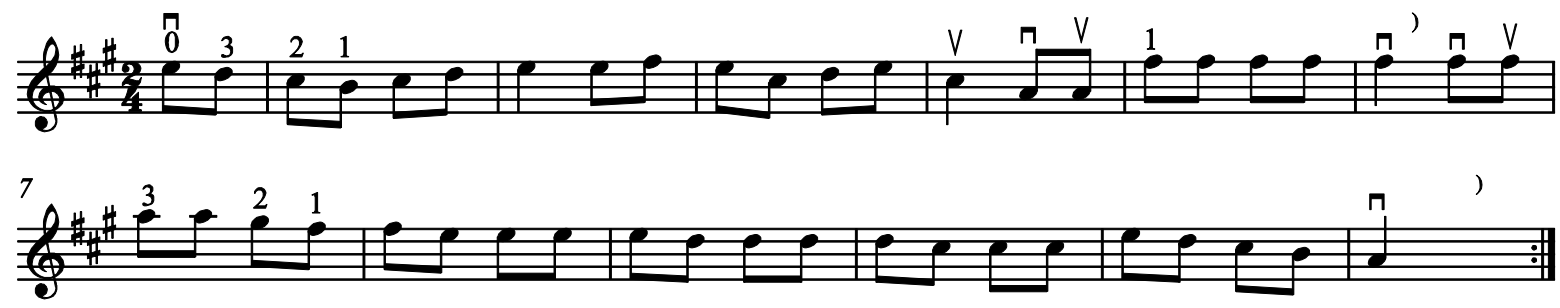
O exercício 87 apresenta a primeira linha melódica coadjuvante para a canção folclórica Passarás, não passarás, com uso do terceiro dedo na corda mi resultando na nota lá dedilhada, marcada com o número 3 , indicativo de seu dedilhado, logo acima da nota.

\section{Passarás, não passarás 1}

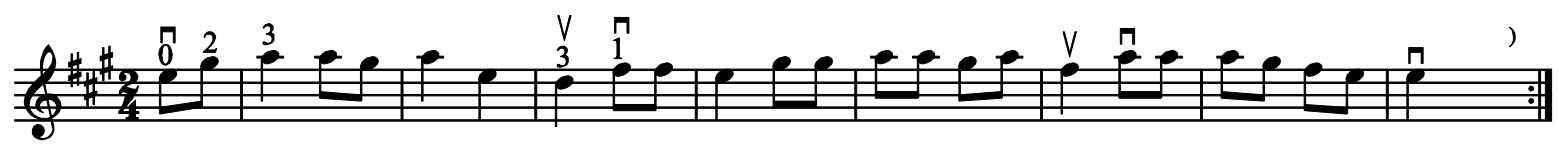

O exercício seguinte é o mesmo que o anterior, acrescido da linha do professor. A tonalidade apresentada é de lá maior.

\section{7a. Passarás, não passarás 1a}

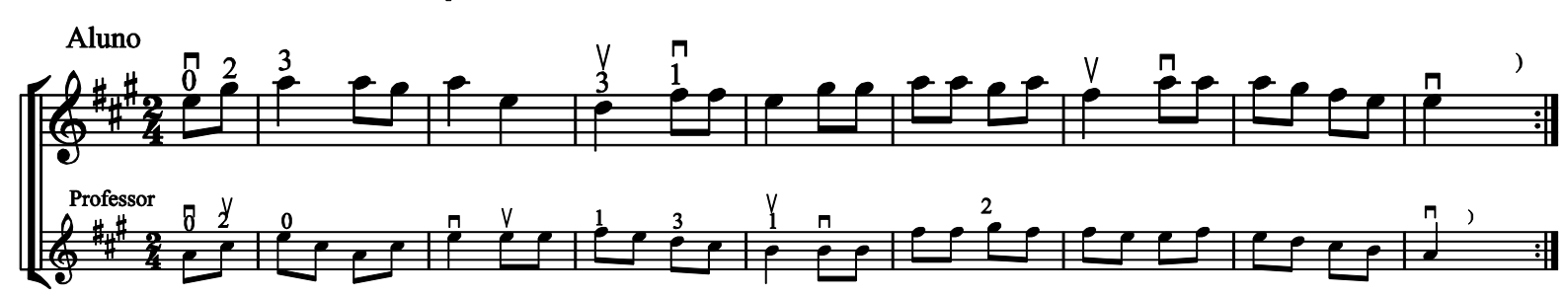

O exercício 88 apresenta a primeira linha melódica coadjuvante para a canção folclórica Canário, com uso do terceiro dedo na corda mi, resultando na nota lá dedilhada.

\section{Canário 1}
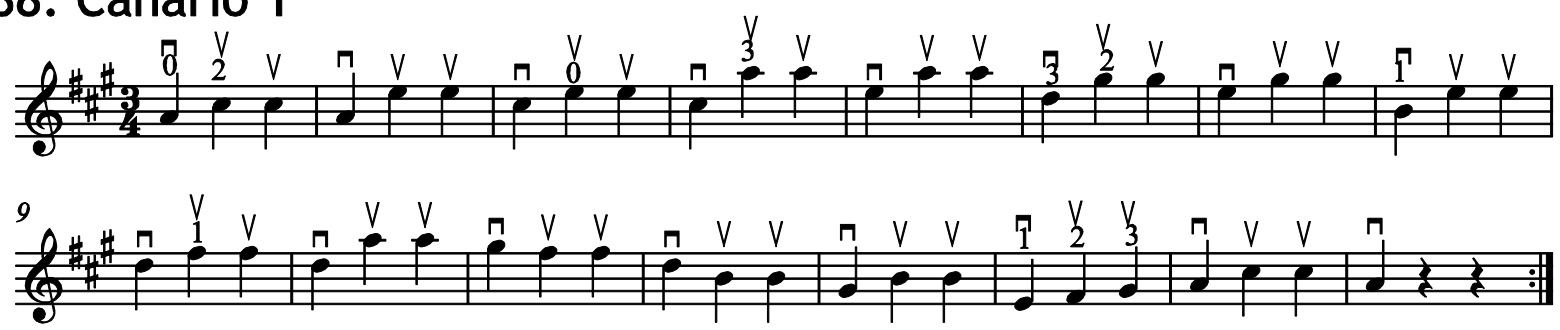
O exercício seguinte é o mesmo que o anterior, acrescido da linha do professor. A tonalidade apresentada é de lá maior.

\section{8a. Canário 1a}
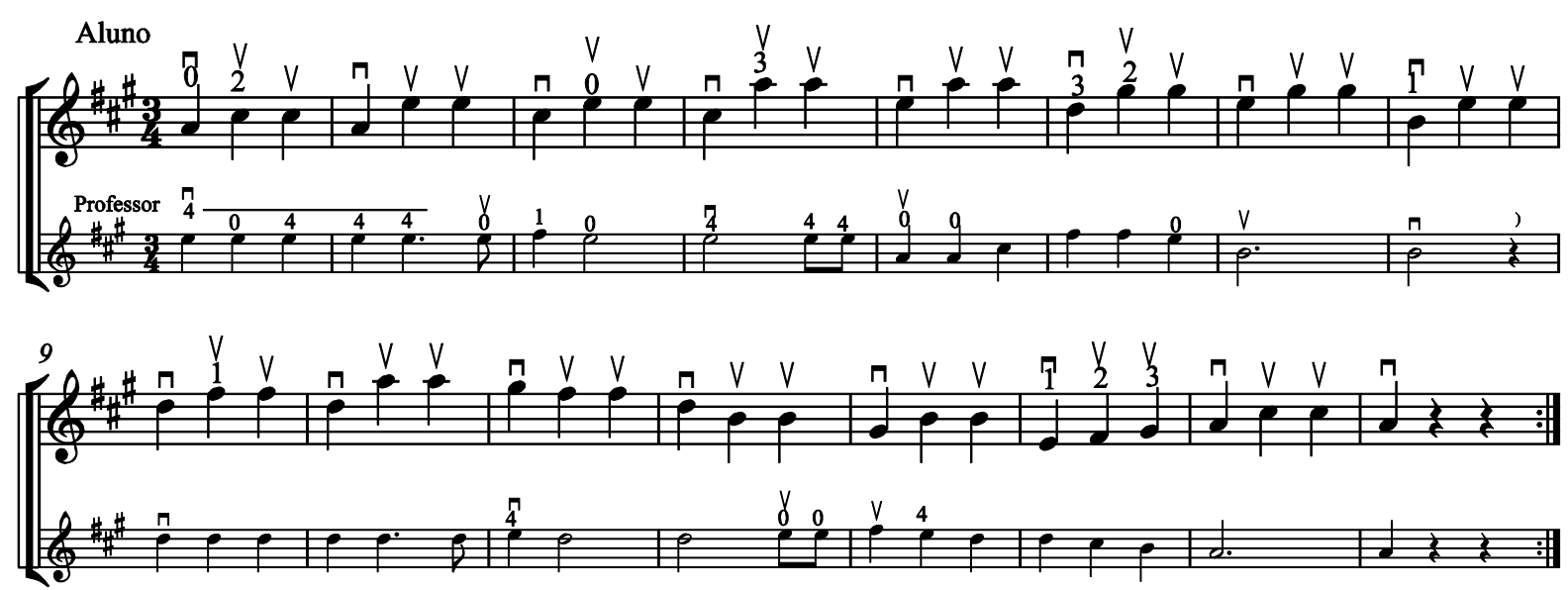

O exercício 89 apresenta um novo elemento musical, que é o ponto de aumento nas mínimas.

\section{Ponto de aumento}
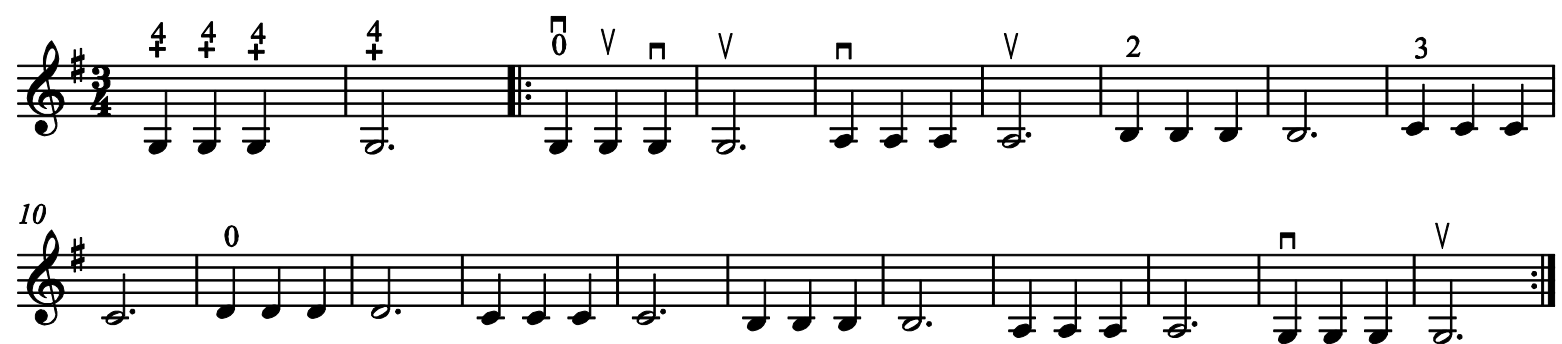

\section{Lição 9}

A lição 9 é composta por 10 exercícios, do número 90 ao 99 . O conteúdo técnico desenvolvido nesta lição segue abaixo:

- Ligadura;

- Escalas de sol maior, ré maior e lá maior com ligaduras;

- Permanência do primeiro, do segundo e do terceiro dedos nas cordas com ligaduras enquanto se toca em outra corda;

- Notação musical das casas de repetição, casas 1 e 2. 
O exercício 90 apresenta a ligaduras entre notas em graus conjuntos, intercaladas por pausas de mínimas. O aluno deve tocar as duas notas em uma só direção do arco. A pausa deve ser utilizada para preparar o braço para o próximo movimento.

\section{Ligadura}

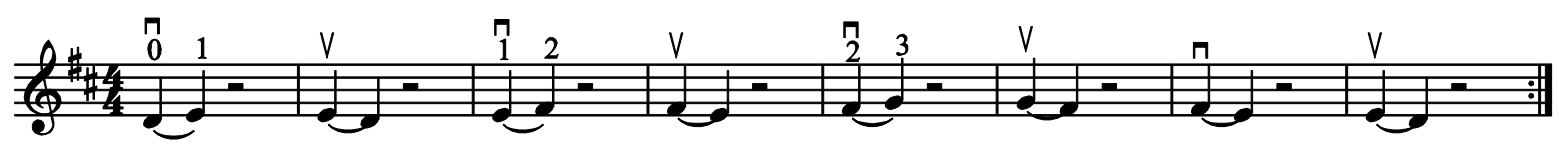

O exercício 91 apresenta ligaduras entre notas em graus conjunto, com mínimas e semínimas.

91.

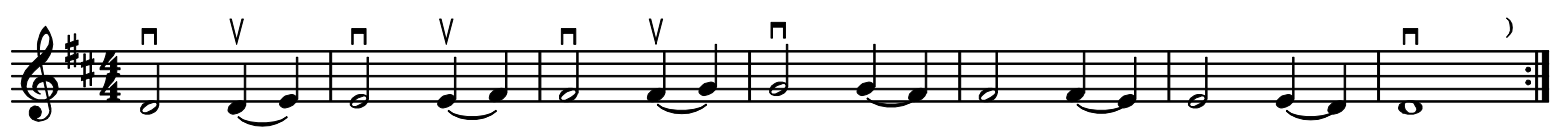

O exercício 92 apresenta ligaduras em colcheias e ligaduras de semínimas com colcheias.

92.
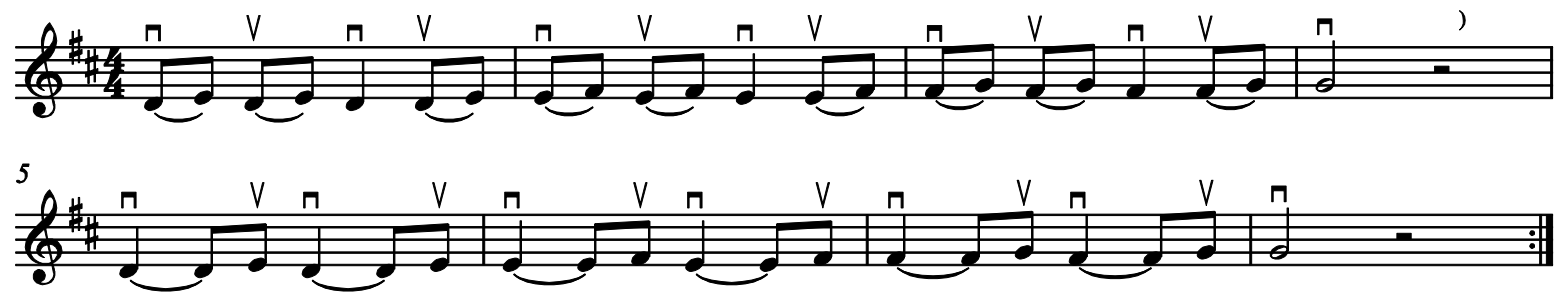

O exercício 93 apresenta semínimas ligadas a colcheias, e semínimas com ponto de aumento. 


\section{Seminímas com ponto de aumento}

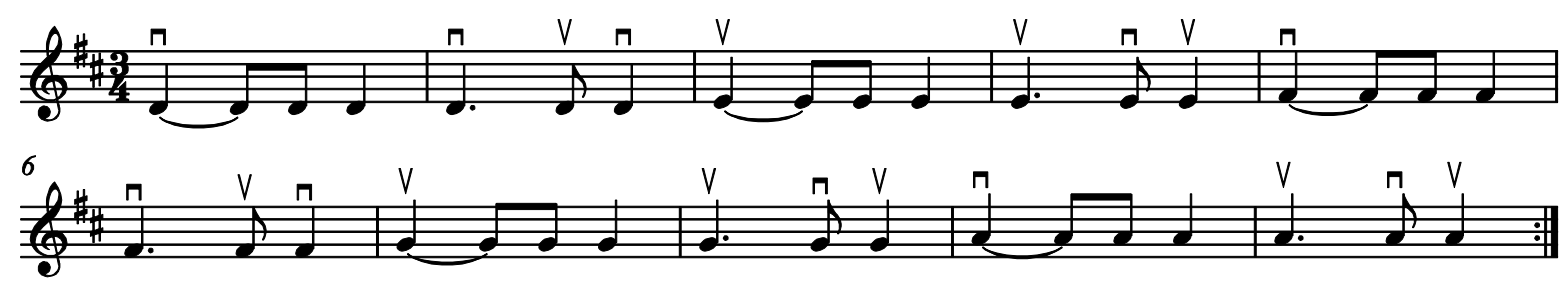

O exercício 94 apresenta escalas de sol maior, ré maior e lá maior em grau conjunto com ligaduras.

94.

A

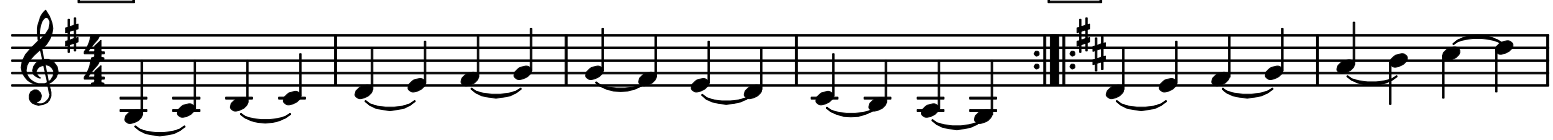

C

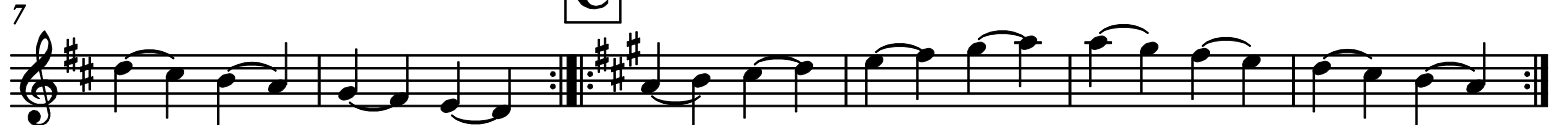

O exercício 95 apresenta escala de sol maior, ré maior e lá maior com salto de intervalo de terças com ligaduras.

95.

$\mathbf{A}$

B

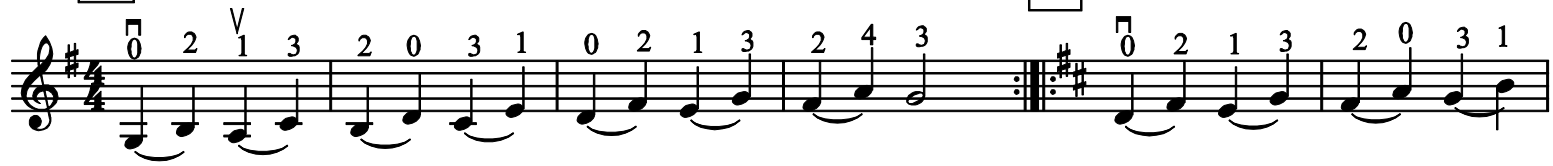

C

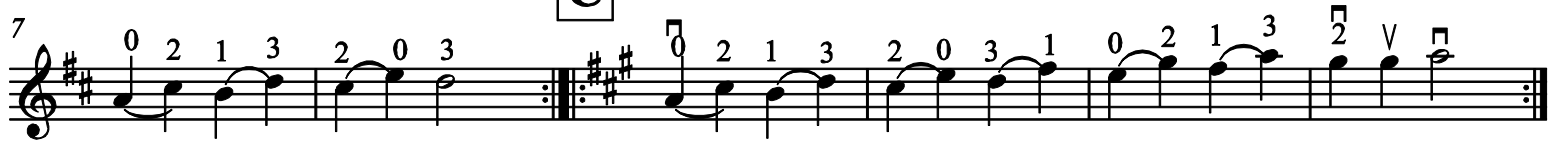

O exercício 96 apresenta ligaduras nas cordas sol e ré com permanência do primeiro dedo na corda. $\mathrm{O}$ dedo deve permanecer preso à corda enquanto durar $\mathrm{O}$ traço indicativo escrito ao lado do dedilhado. 
96.
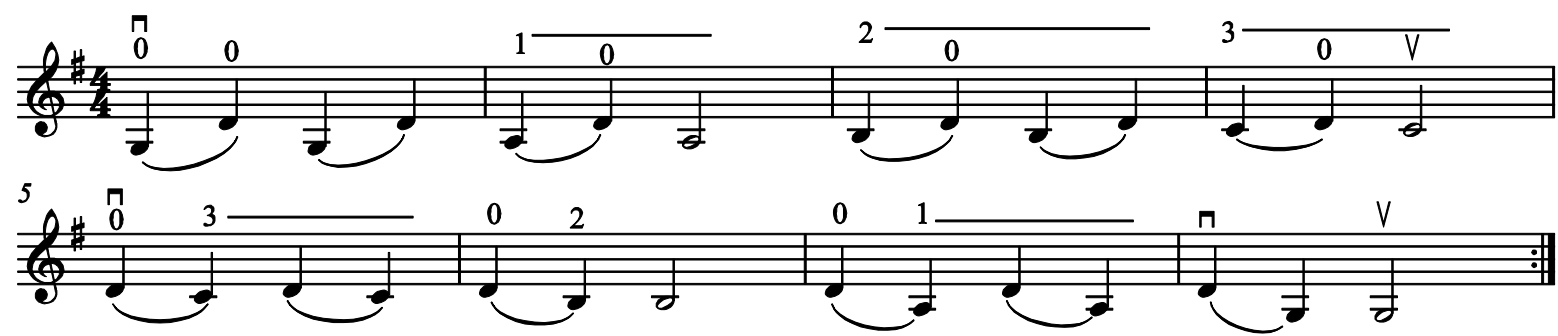

O exercício 97 apresenta a canção folclórica original Cai, cai balão. O arco deve ser posicionado na ponta no início do exercício.

\section{Cai, cai balão - melodia original}
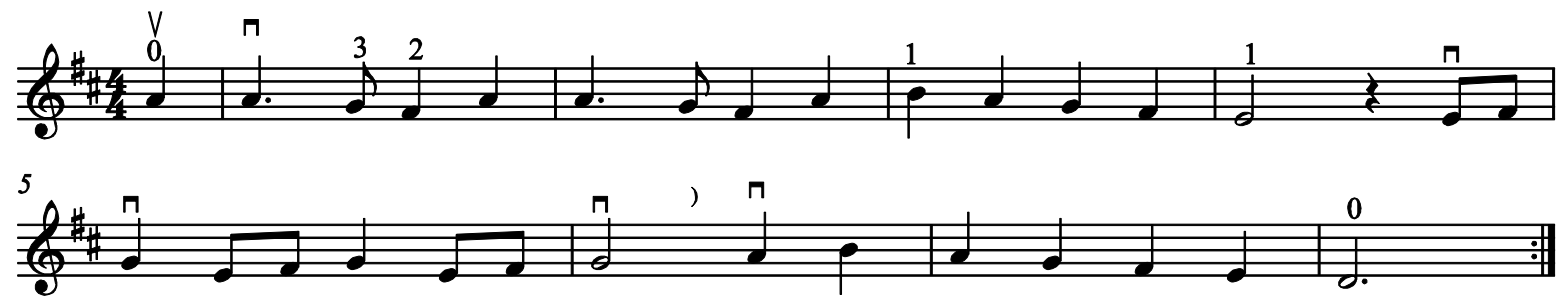

O exercício 98 apresenta a canção folclórica original 0 cravo brigou com a rosa, com as duas casas de repetição, casa 1 e 2 . $O$ aluno deve tocar na primeira vez a casa 1 e repetir o exercício desde a primeira barra de repetição situada no primeiro compasso. Na segunda vez, o aluno deve tocar até o final do compasso 7 e pular até a casa 2.

\section{O cravo brigou com a rosa - melodia original}

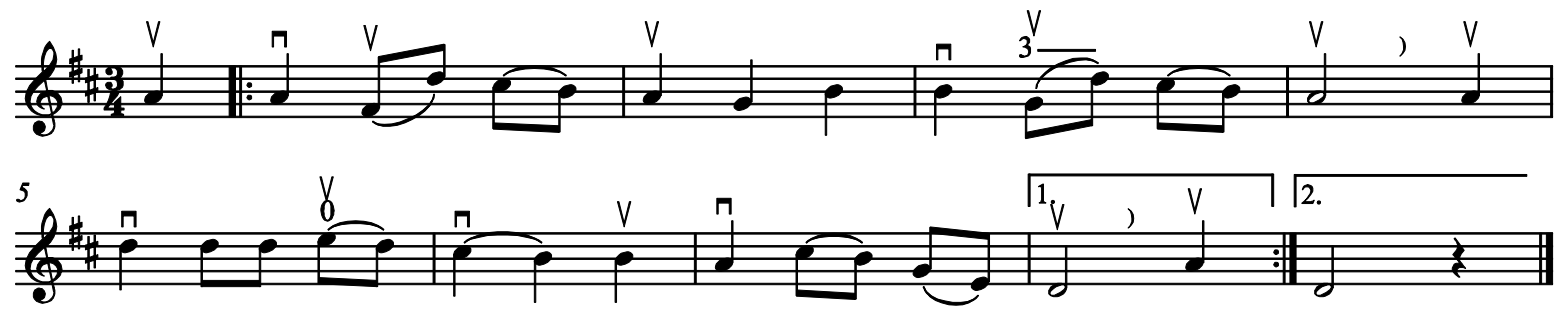

O exercício 99 apresenta a canção folclórica original Hei de namorar. 
99. Hei de namorar - melodia original
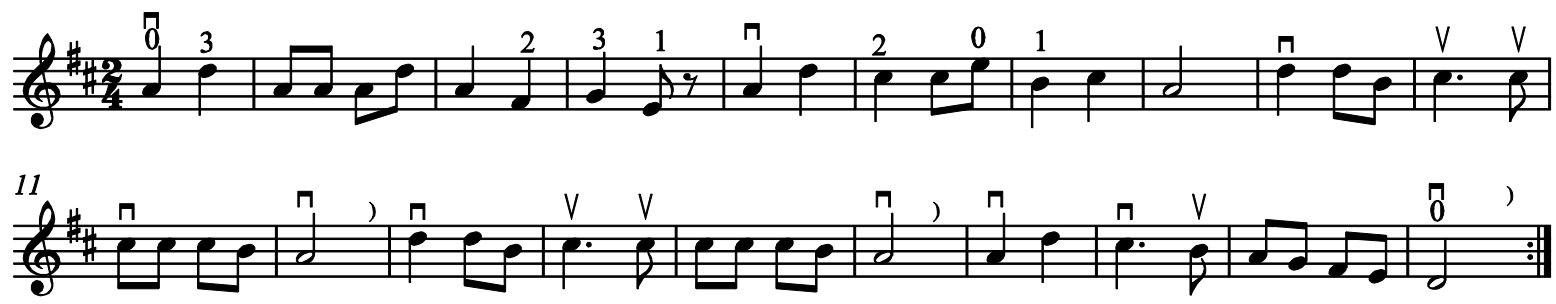

\section{Lição 10}

A lição 10 é composta por 10 exercícios, do número 100 ao 109. O conteúdo técnico desenvolvido nesta lição segue abaixo:

- Figura musical da semicolcheia;

- Síncopas em colcheias e semicolcheias;

- Ponto de aumento em semínimas e colcheias;

- Sinal de bequadro.

O exercício 100 apresenta a figura musical das semicolcheias. A arcada executada deve ser na metade superior do arco (do meio até a ponta), com mais arco nas semínimas e colcheias, e pouco arco nas semicolcheias.

\section{Semicolcheias}

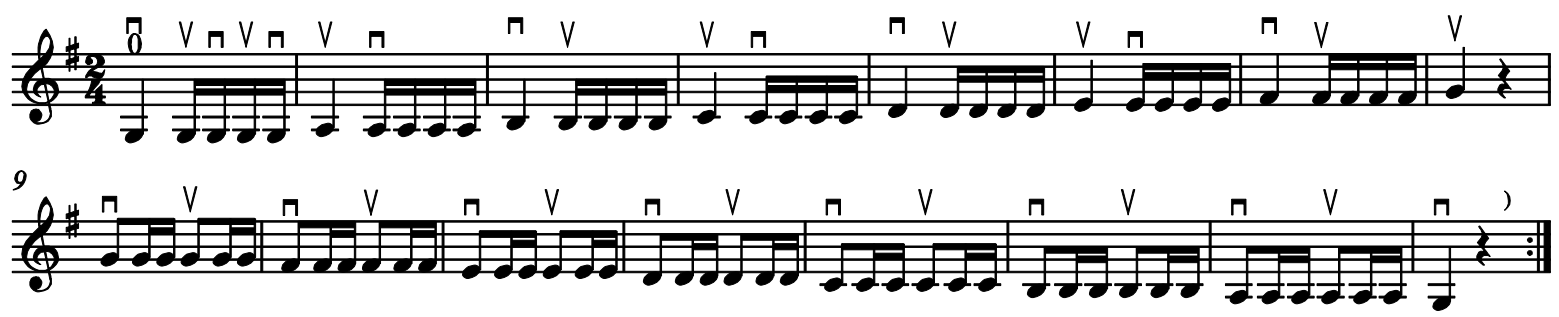

O exercício 101 apresenta escala de sol maior com colcheias e semicolcheias em síncopas.

101.
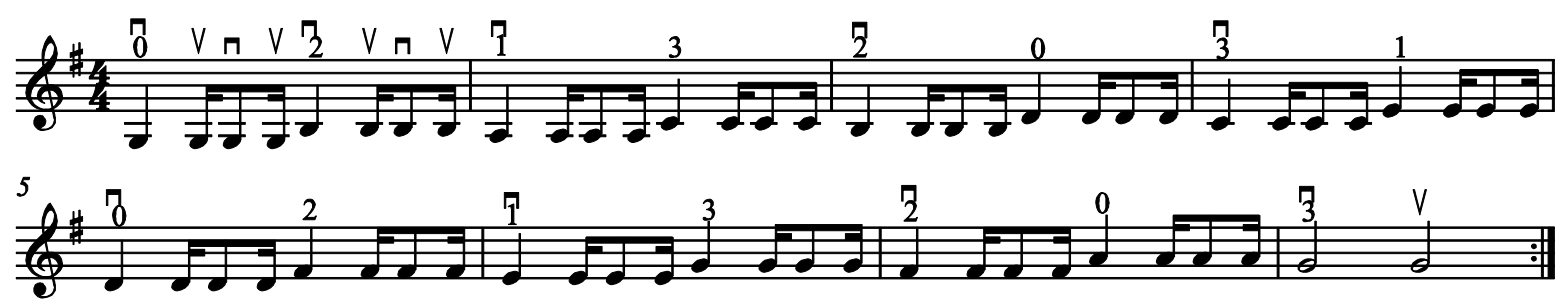
O exercício 102 apresenta primeira linha melódica coadjuvante da canção folclórica Fui passar na ponte, com uso do sinal de bequadro indicando a volta da nota sol para o estado natural, em vez de ser tocada como sustenido devido à tonalidade de sua armadura de clave.

\section{Fui passar na ponte 1 - sinal de bequadro}

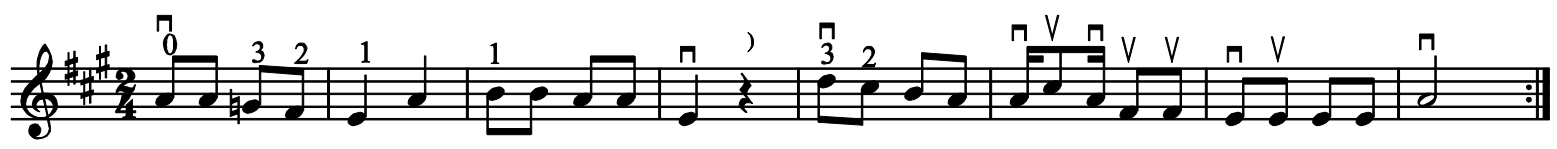

O exercício seguinte é o mesmo que o anterior, acrescido da linha do professor. A tonalidade apresentada é de lá maior.

\section{2a. Fui passar na ponte 1a}

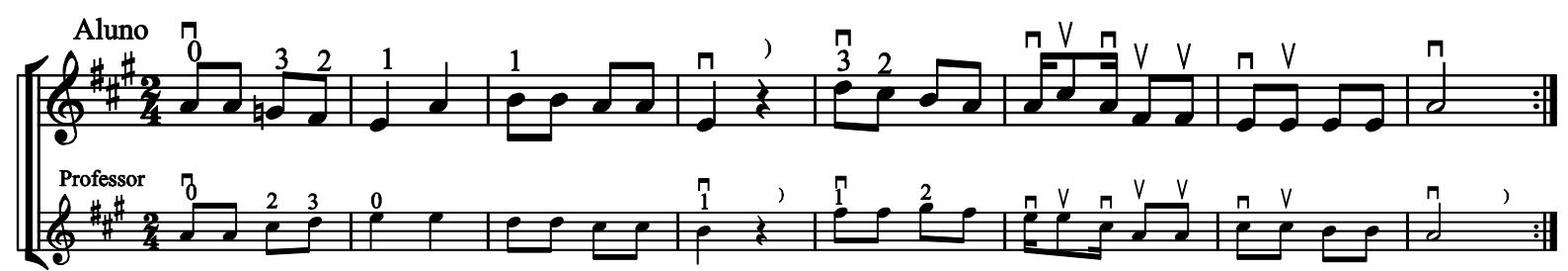

O exercício 103 apresenta a canção folclórica original Fui passar na ponte.

\section{Fui passar na ponte - melodia original}

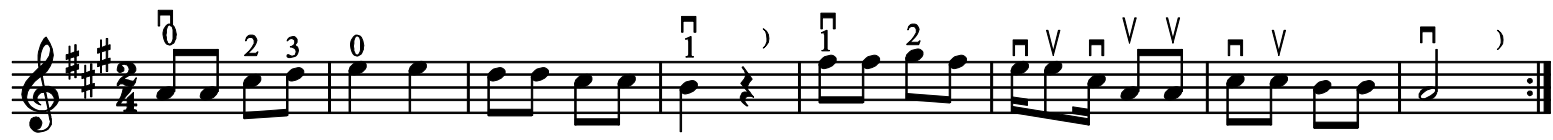

O exercício 104 apresenta escala de lá maior com uso de semínimas e colcheias na mesma altura, com ponto de aumento. Devem ser realizadas duas arcadas no mesmo sentido do arco dos compassos 1 a 8 , exercitando o controle do movimento da mão direita, as notas devem ser destacadas uma da outra por uma parada rápida do movimento. $A$ arcada nos compassos 9 a 12 é alternada. 
104.

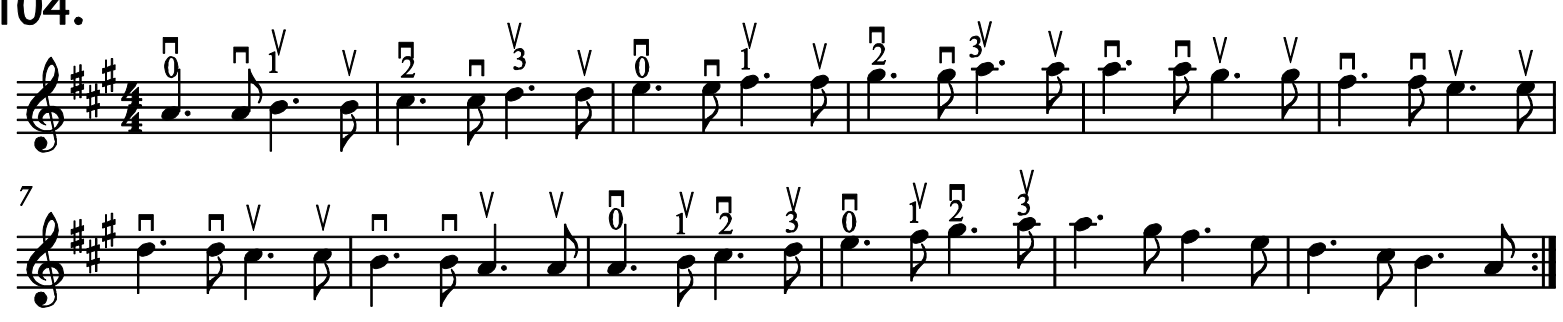

O exercício 105 apresenta a canção folclórica original Pirulito.

105. Pirulito - melodia original

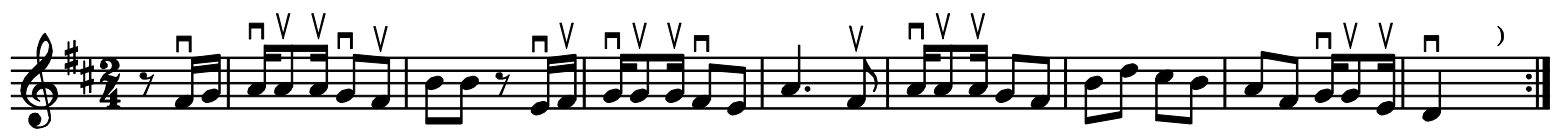

O exercício 106 apresenta colcheia com ponto de aumento.

106.

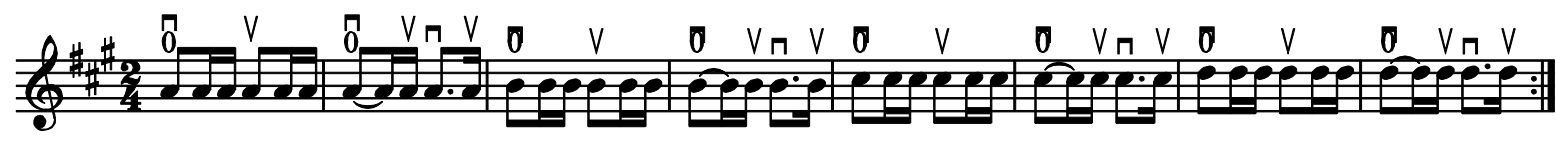

O exercício 107 apresenta escala de ré maior em semicolcheias com ligaduras.

107.

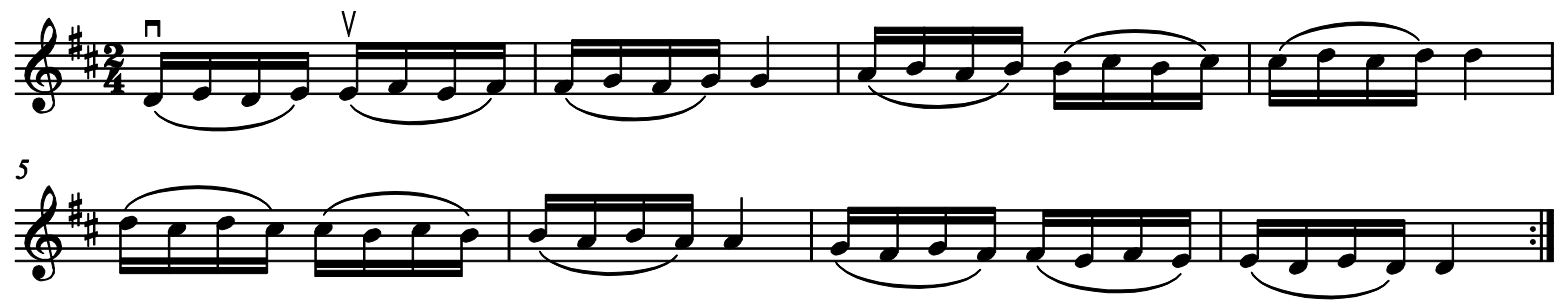

O exercício 108 apresenta escala de lá maior e uso de colcheias com ponto de aumento. As arcadas apresentadas são diferentes na escala ascendente da escala descendente. 
108.

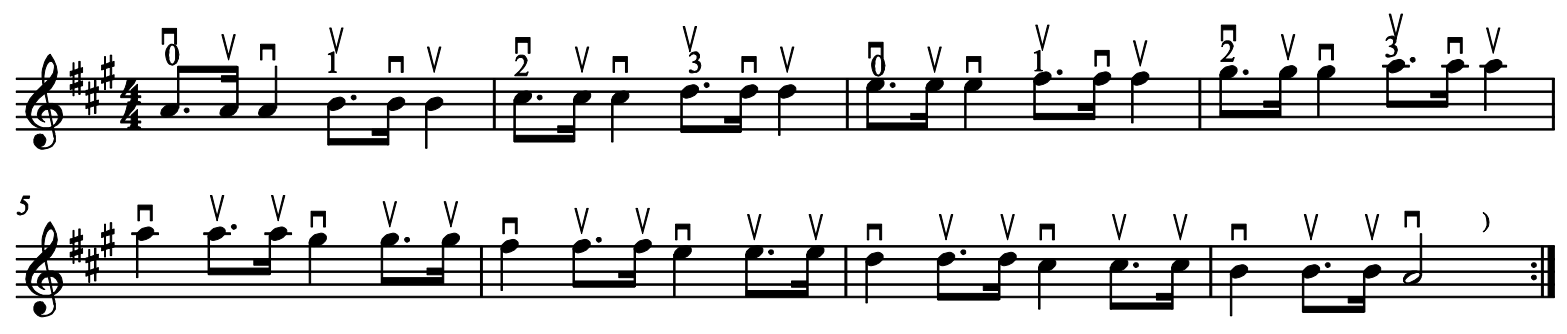

O exercício 109 apresenta a canção folclórica original Lá na ponte da Vinhaça, com colcheias e semicolcheias ligadas.

\section{Lá na ponte da Vinhaça - melodia original}

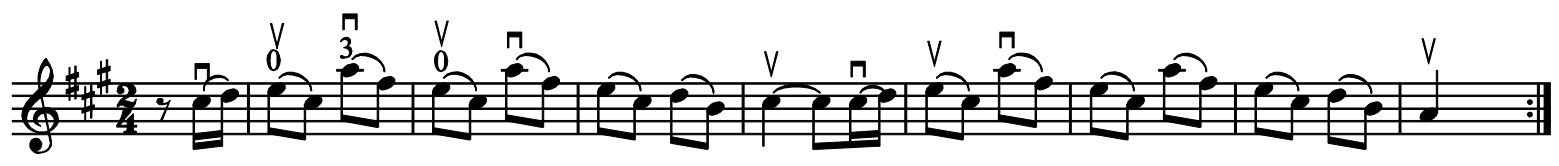

\section{Lição 11}

A lição 11 é composta por 10 exercícios, do número 110 ao 119. O conteúdo técnico desenvolvido nesta lição segue abaixo:

- Colocação do quarto dedo na corda ré, resultando na nota lá dedilhada, marcada com o número 4, indicativo de seu dedilhado, logo acima ou abaixo da nota;

- Colocação do quarto dedo na corda lá, resultando na nota mi dedilhada, marcada com o número 4, indicativo de seu dedilhado, logo acima ou abaixo da nota;

- Colocação do quarto dedo na corda sol, resultando na nota ré dedilhada, marcada com o número 4, indicativo de seu dedilhado, logo acima ou abaixo da nota;

- Colocação do quarto dedo na corda mi, resultando na nota si, marcada com o número 4, indicativo de seu dedilhado, logo acima ou abaixo da nota;

- Notação musical D.C ou da capo, significando um retorno ao início do exercício. 
O exercício 110 apresenta a colocação do quarto dedo na corda ré, resultando na nota lá dedilhada, marcada com o número 4, indicativo de seu dedilhado.

O terceiro dedo deve permanecer na corda ré, enquanto durar o traço indicativo escrito ao lado do dedilhado e o arco estiver tocando na corda lá. No compasso 6, a alternância entre corda solta lá e o lá realizado com o quarto dedo na corda ré tem o objetivo de manter a forma da mão esquerda com os dedos sempre curvos e com a ponta deles nas cordas.

Se a mão esquerda estiver fora da forma, e os dedos ficarem inclinados, não será possível realizar esse exercício corretamente, pois a inclinação indevida dos dedos interferirá na produção de um som limpo, sem ruídos.

\section{Quarto dedo na corda Ré}

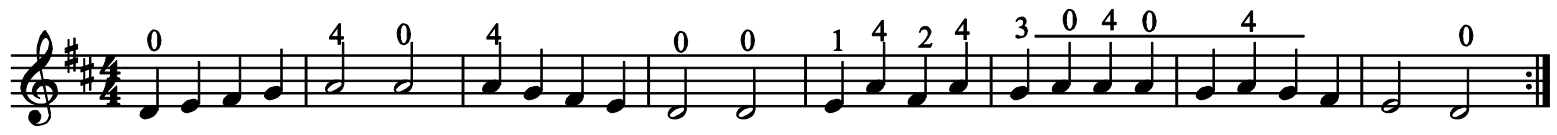

O exercício 111 apresenta a canção folclórica original Bambalalão, com uso do quarto dedo na corda ré, resultando na nota lá dedilhada.

\section{Bambalalão - melodia original}

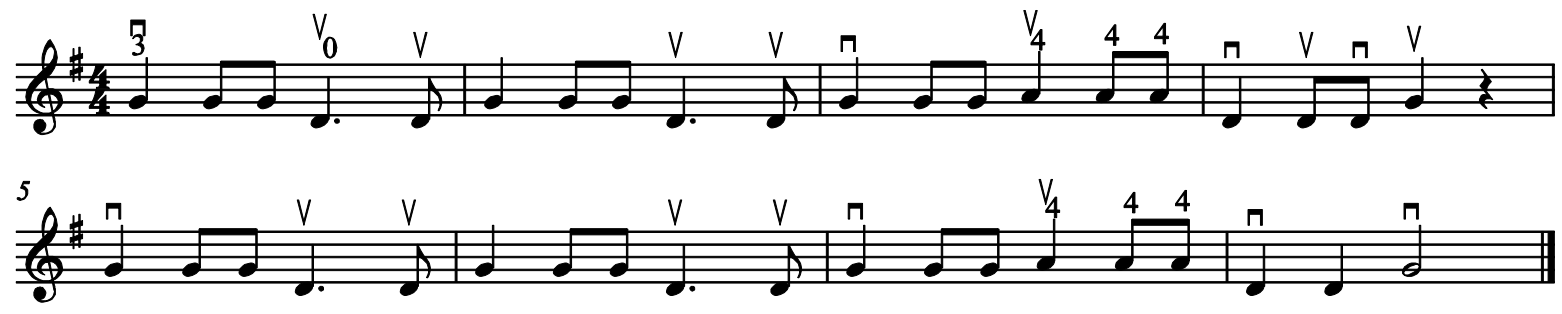

O exercício 112 apresenta a colocação do quarto dedo na corda lá, resultando na nota mi dedilhada, marcada com o número 4, indicativo de seu dedilhado. $\mathrm{O}$ terceiro dedo deve permanecer na corda lá, enquanto durar o traço indicativo escrito ao lado do dedilhado.

\section{Quarto dedo na corda Lá}

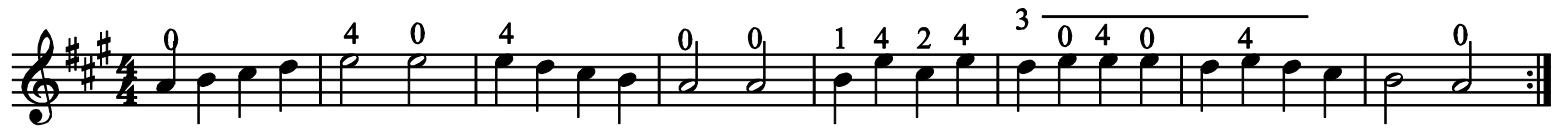


O exercício 113 apresenta a canção folclórica original Canário, com uso do quarto dedo na corda lá, resultando na nota mi dedilhada. Também faz uso das duas casas de repetição.

No primeiro compasso a alternância entre corda solta mi e o mi realizado com o quarto dedo na corda lá tem o objetivo de manter a forma da mão esquerda.

\section{Canário - melodia original}
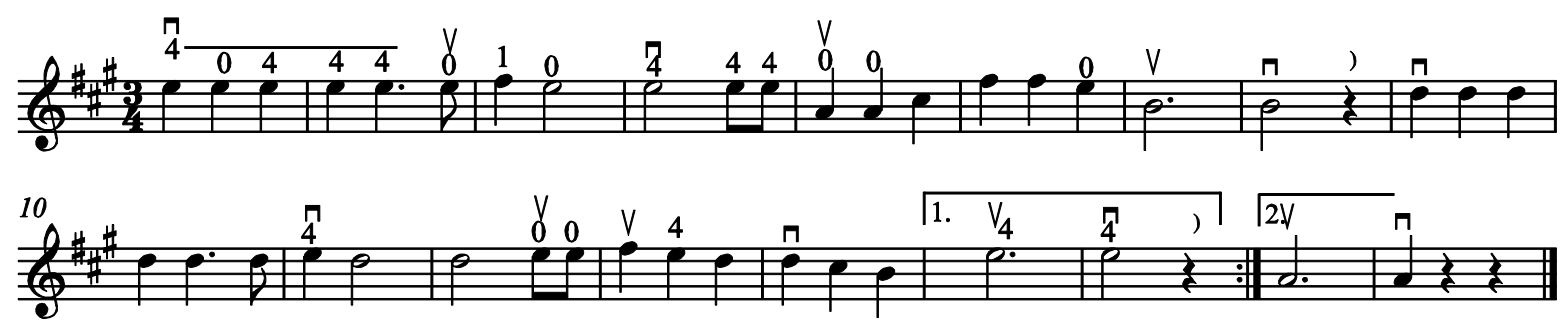

O exercício 114 apresenta a colocação do quarto dedo na corda sol, resultando na nota ré dedilhada marcada com o número 4, indicativo de seu dedilhado. O terceiro dedo deve permanecer na corda sol, enquanto durar o traço indicativo escrito ao lado do dedilhado.

\section{Quarto dedo na corda Sol}

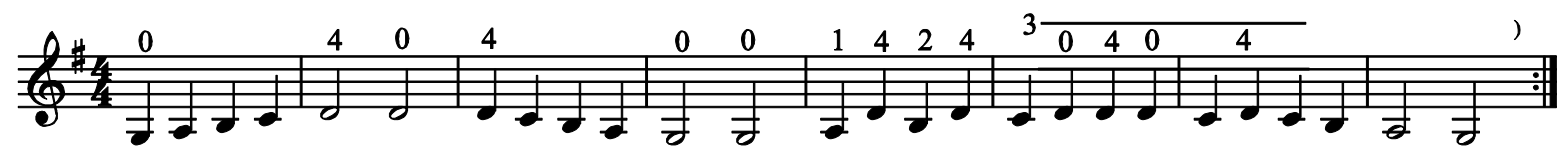

O exercício 115 apresenta a terceira linha melódica coadjuvante para a canção folclórica Bambalalão, com uso do quarto dedo na corda sol, resultando na nota ré dedilhada.

\section{Bambalalão 3}

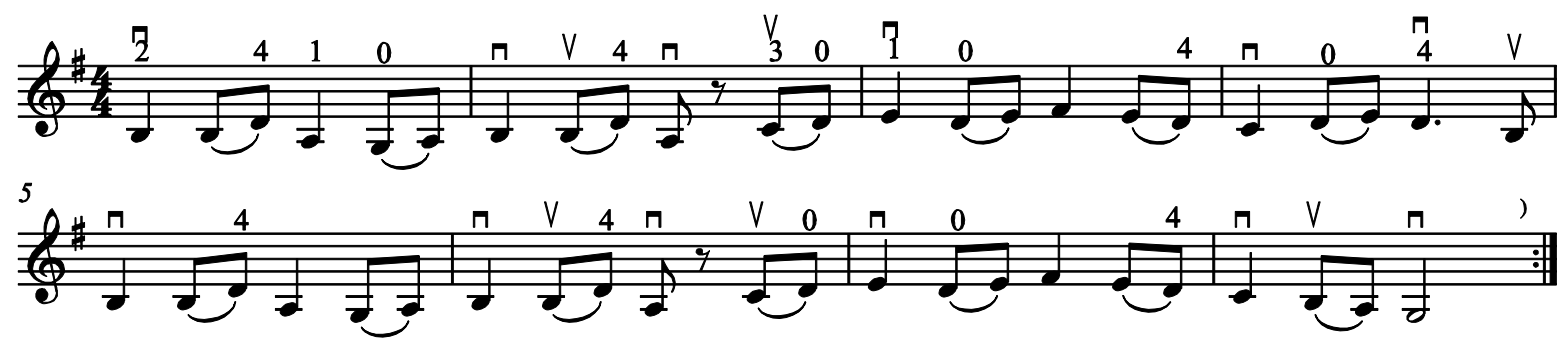


O exercício seguinte é o mesmo que o anterior, acrescido da linha do professor. A tonalidade apresentada é de sol maior.

\section{5a. Bambalalão 3a}
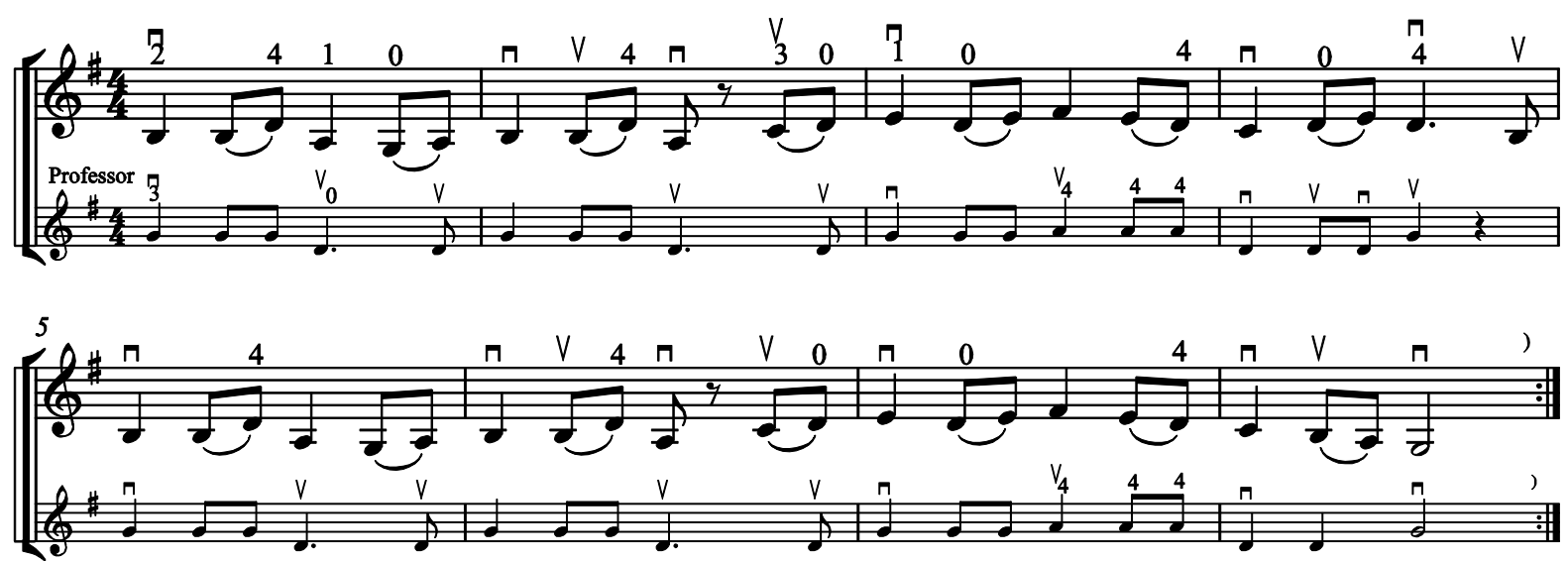

O exercício 116 apresenta a segunda linha melódica coadjuvante para a canção folclórica $A$ cantiga de ninar, com uso do quarto dedo nas cordas ré e sol.

\section{A cantiga de ninar 2}

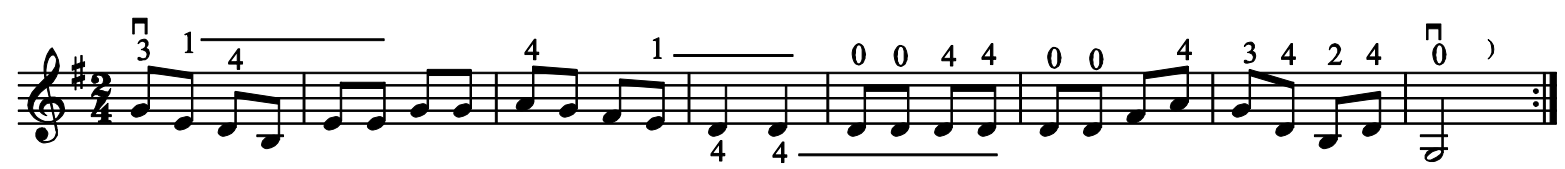

O exercício seguinte é o mesmo que o anterior, acrescido da linha do professor. A tonalidade apresentada é de sol maior.

\section{6a. A cantiga de ninar $2 a$}

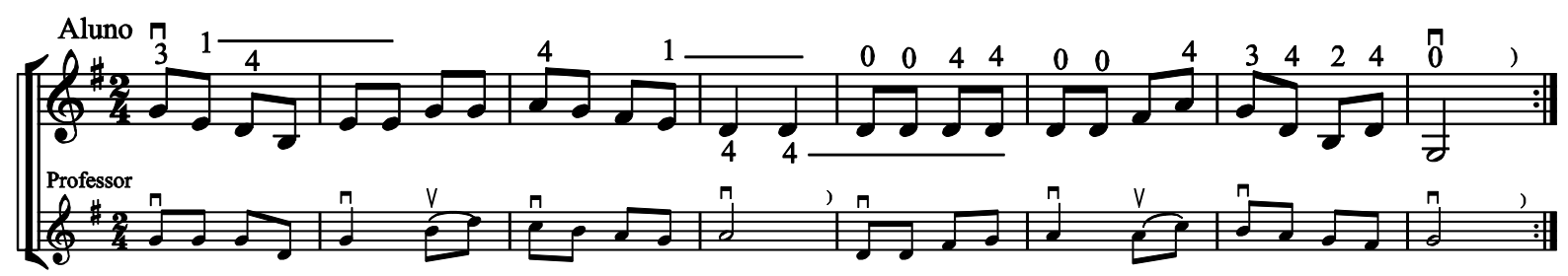

O exercício 117 apresenta a terceira linha melódica coadjuvante para a canção folclórica Ó ciranda, ó cirandinha, com uso do quarto dedo nas cordas ré e sol. 


\section{7. Ó ciranda, ó cirandinha 3}

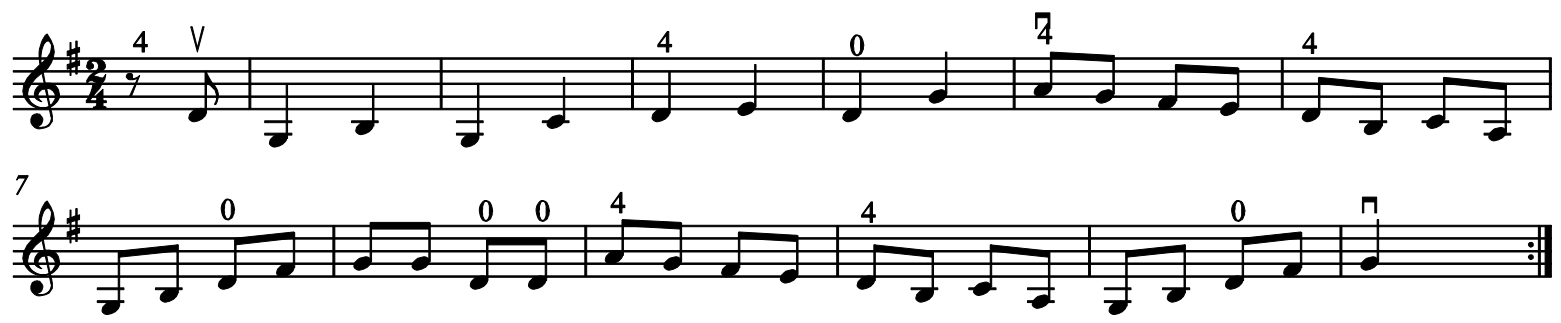

O exercício seguinte é o mesmo que o anterior, acrescido da linha do professor. A tonalidade apresentada é de sol maior.

\section{7a. Ó ciranda, ó cirandinha 3a}
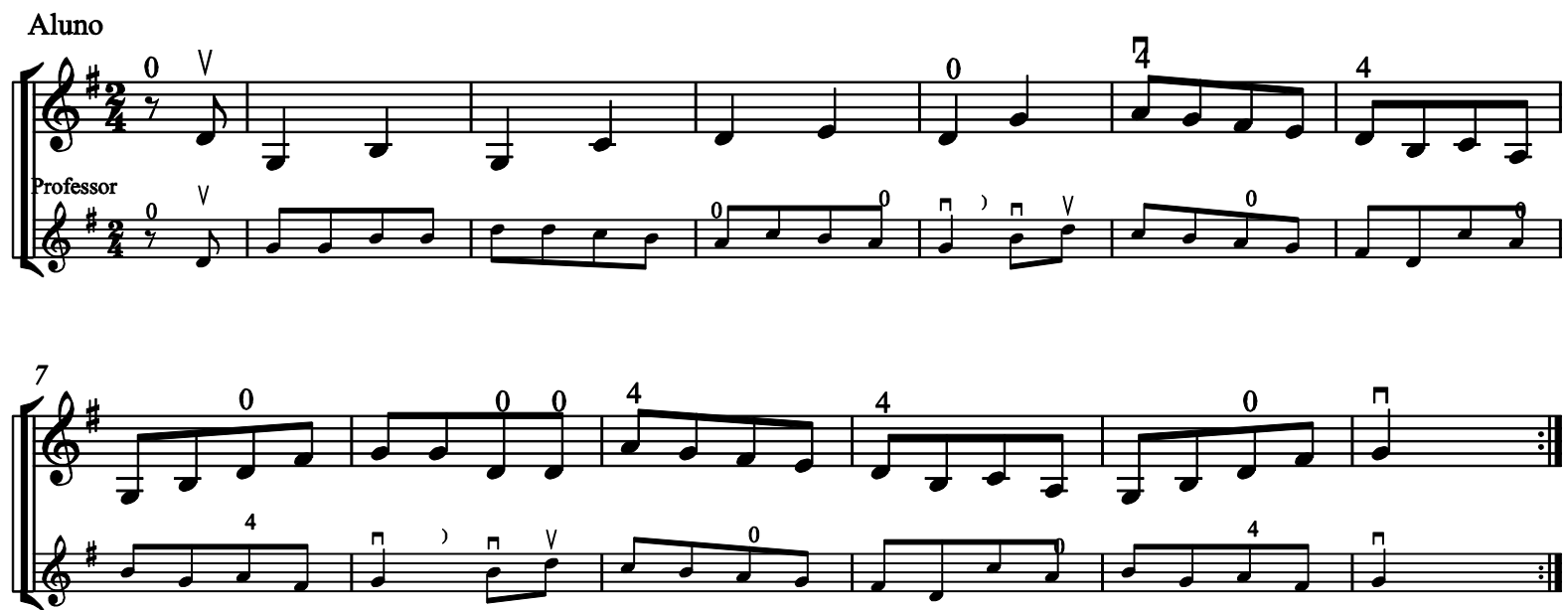

O exercício 118 apresenta a colocação do quarto dedo na corda mi, resultando na nota si, marcada com o número 4, indicativo de seu dedilhado. O terceiro dedo deve permanecer na corda mi, enquanto durar o traço indicativo escrito ao lado do dedilhado.

\section{Quarto dedo na corda $\mathrm{Mi}$}

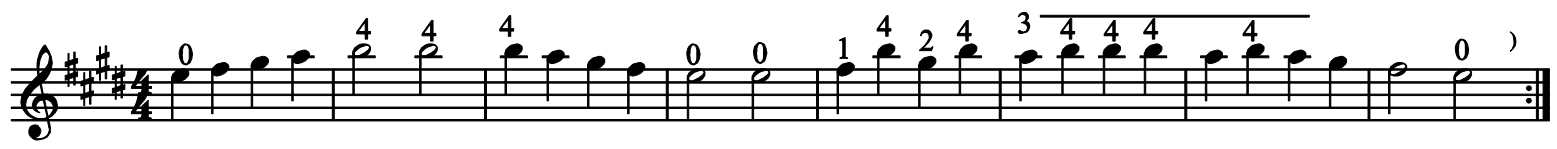

O exercício 119 apresenta a canção folclórica original Soletrando, com uso do quarto dedo na corda mi, resultando na nota si, marcada com o número 4 , indicativo de seu dedilhado. Este exercício apresenta a notação musical D.C. al Fine ou da capo al fine, que significa um retorno do começo, ou seja, voltar a tocar desde o início do exercício, com todas as repetições até o fim, marcado pela palavra Fine. 


\section{Ex. 119 Soletrando - melodia original}
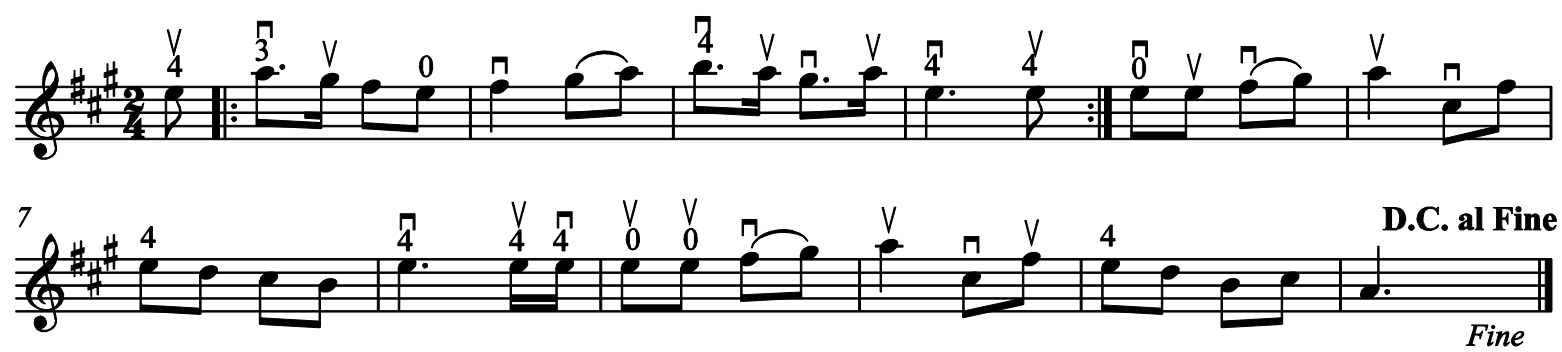

\section{Lição 12}

A lição 12 é composta por 10 exercícios, do número 120 ao 129 . O conteúdo técnico desenvolvido nesta lição segue abaixo:

- Colocação do segundo dedo próximo do primeiro na corda ré, resultando na nota fá natural;

- Colocação do segundo dedo próximo do primeiro na corda ré, resultando na nota dó natural;

- Colocação do segundo dedo próximo do primeiro na corda sol, resultando na nota sib bemol;

- Colocação do segundo dedo próximo do primeiro na corda mi, resultando na nota sol natural.

O exercício 120 apresenta a posição do segundo dedo próximo do primeiro na corda ré. Essa aproximação do segundo dedo deve ser feita arrastando o dedo na corda desde a posição já conhecida, ou seja, o aluno deve colocar o segundo dedo na posição de fá\# e depois arrastá-lo sem perder o contato do dedo com a corda até ficar próximo do primeiro dedo, resultando na nota fá natural, marcada com o sinal de bequadro $\left({ }^{(}\right)$.

As setas ascendentes e descendentes que acompanham o dedilhado indicam o sentido do segundo dedo na corda, que deve ser arrastado em direção à pestana na seta descendente e em direção ao cavalete na seta ascendente. 
120. Segundo dedo junto do primeiro

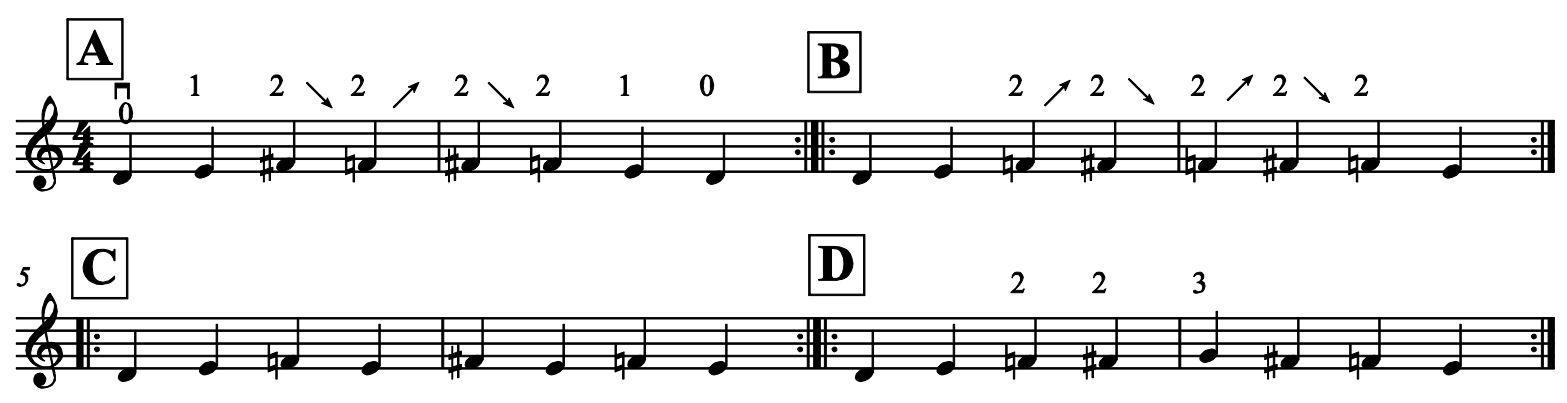

O exercício 121 apresenta uso do segundo dedo próximo do primeiro com salto de intervalos na corda ré. Ressaltamos a importância de o aluno manter o maior número de dedos presos na corda pelo maior tempo possível, com o objetivo de desenvolver a forma dos dedos da mão esquerda sobre as cordas. Por isso, quando o aluno colocar o segundo dedo na corda, o primeiro dedo deve ser colocado ao mesmo tempo e assim sucessivamente.

121.

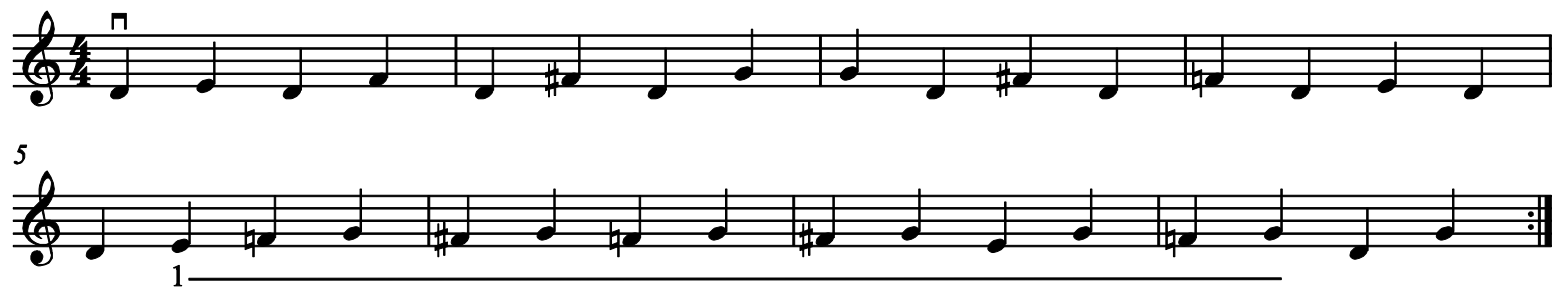

O exercício 122 apresenta a posição do segundo dedo próximo do primeiro na corda lá, resultando na nota dó natural, marcada com o sinal de bequadro (). O exercício segue as mesmas orientações do exercício 120.

122.

$\mathrm{A}$

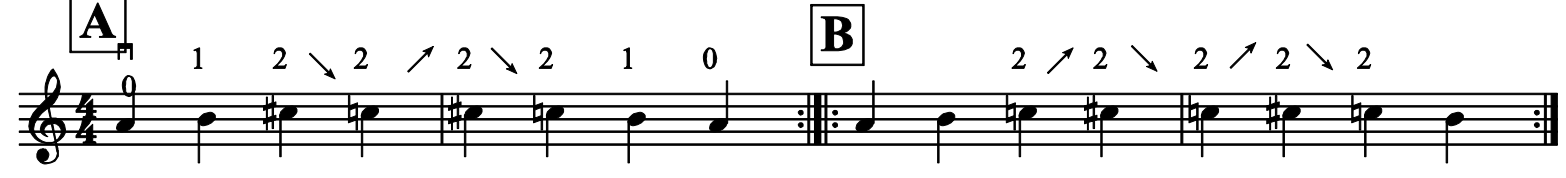

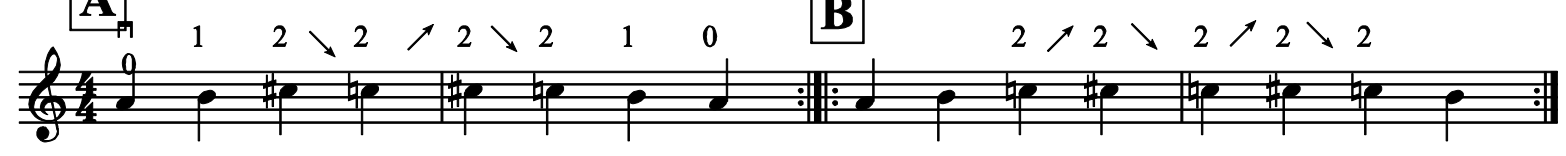

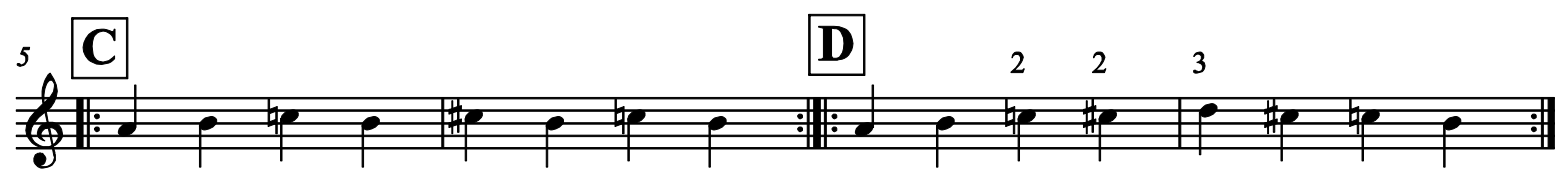


O exercício 123 apresenta uso do segundo dedo próximo do primeiro com salto de intervalos na corda lá. $O$ exercício segue as mesmas orientações do exercício 121.

\section{3.}
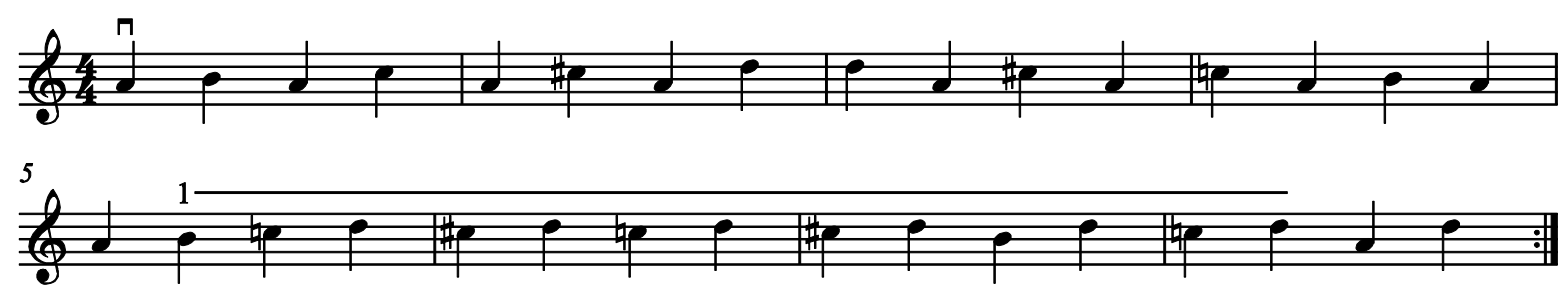

O exercício 124 apresenta a canção folclórica original $A$ cantiga de ninar, com uso do segundo dedo próximo do primeiro na corda lá, resultando na nota dó natural.

\section{A cantiga de ninar - melodia original}

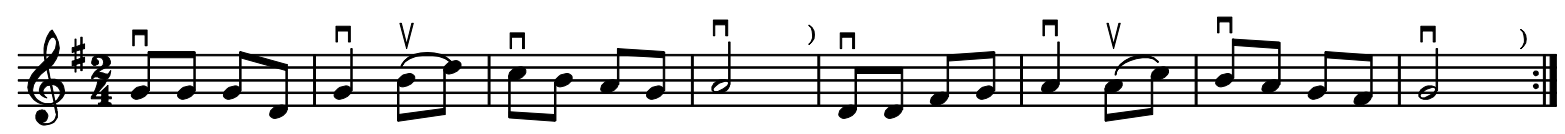

O exercício 125 apresenta a posição do segundo dedo próximo do primeiro na corda sol, resultando na nota si bemol (b). O exercício segue as mesmas orientações do exercício 120.

\section{5.}
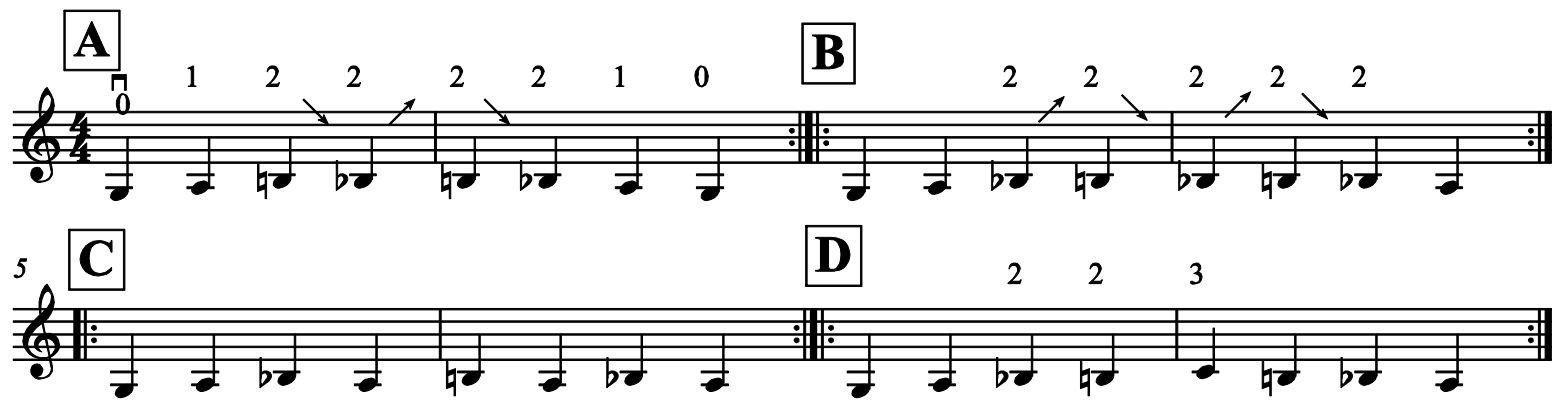

O exercício 126 apresenta uso do segundo dedo próximo do primeiro, com salto de intervalos na corda sol. O exercício segue as mesmas orientações do exercício 121. 
192

126.
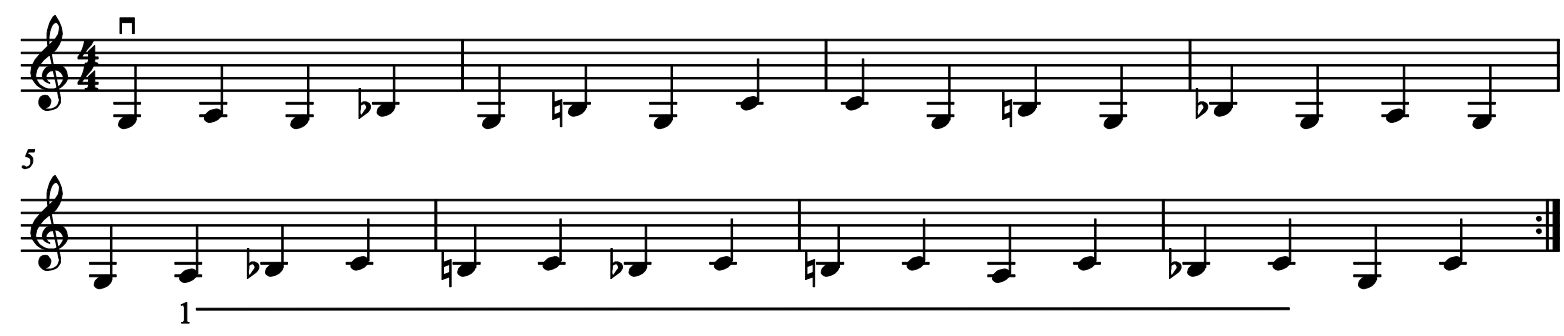

O exercício 127 apresenta a posição do segundo dedo próximo do primeiro na corda mi, resultando na nota sol natural, marcada com o sinal de bequadro (a). $O$ exercício segue as mesmas orientações do exercício 120.

127.
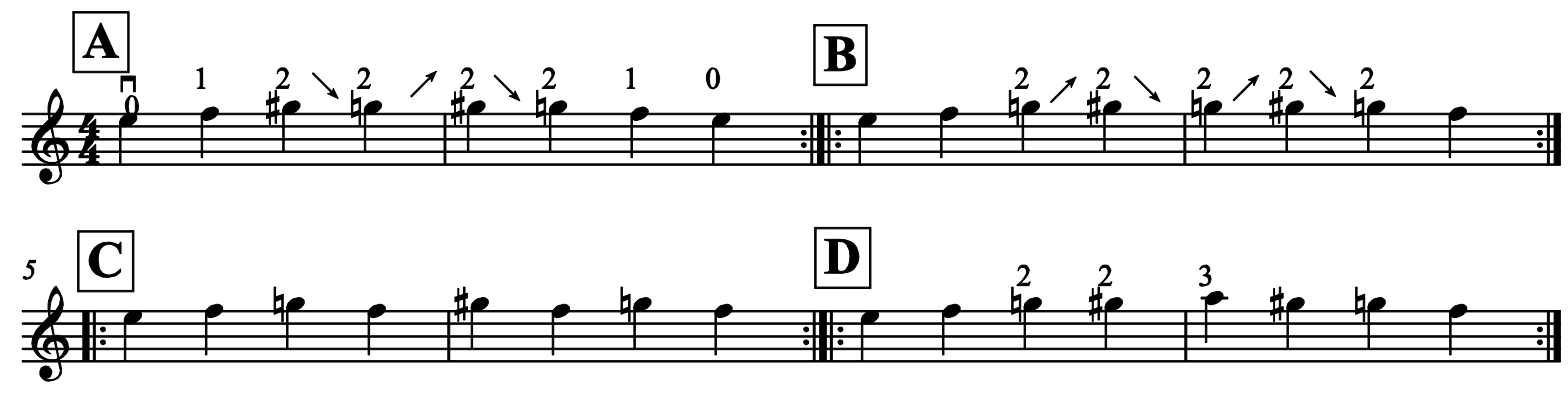

O exercício 128 apresenta uso do segundo dedo próximo do primeiro, com salto de intervalos na corda mi. O exercício segue as mesmas orientações do exercício 121.

128.
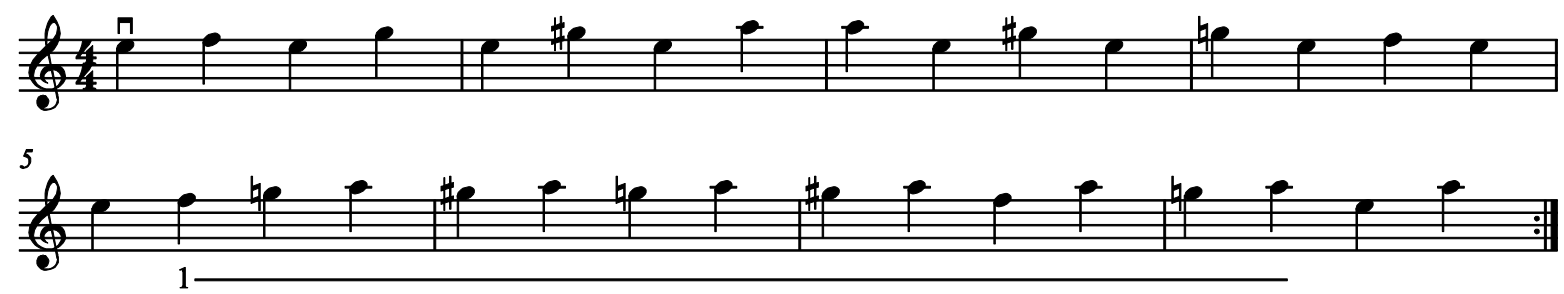
O exercício 129 apresenta a canção folclórica original Capelinha de melão, com uso do segundo dedo próximo do primeiro nas cordas mi e lá, resultando nas notas sol e dó naturais.

\section{Capelinha de melão - melodia original}

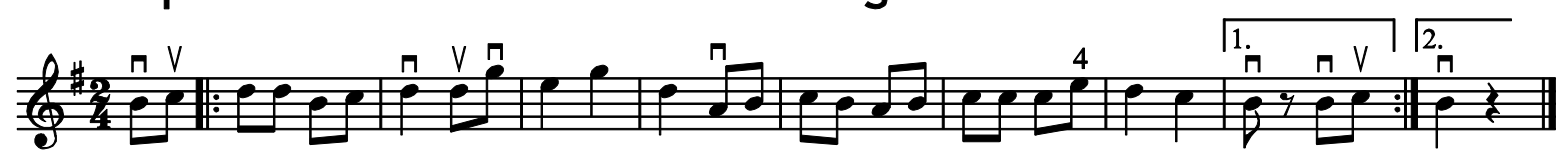

\section{Lição 13}

A lição 13 é composta por 10 exercícios, do número 130 ao 139. O conteúdo técnico desenvolvido nesta lição segue abaixo:

- Colocação do segundo dedo em diversas posições nas diferentes cordas durante um mesmo exercício;

- Alternância de uso de quarto dedo e corda solta para uma mesma altura de notas repetidas;

- Ligaduras entre notas da mesma altura no mesmo compasso e entre diferentes compassos;

- Acentos musicais;

- Staccato;

- Divisão de arco com arcadas de duas notas na mesma direção;

- Permanência de dedos na corda.

O exercício 130 apresenta a canção folclórica original Ó ciranda, ó cirandinha, com uso do quarto dedo na corda ré e segundo dedo próximo do primeiro na corda lá. O aluno deve considerar com atenção o uso do segundo dedo, que na corda ré é afastado do primeiro dedo por causa do fá\#, e na corda lá é próximo do primeiro por causa do dó natural. 
130. Ó ciranda, ó cirandinha - melodia original

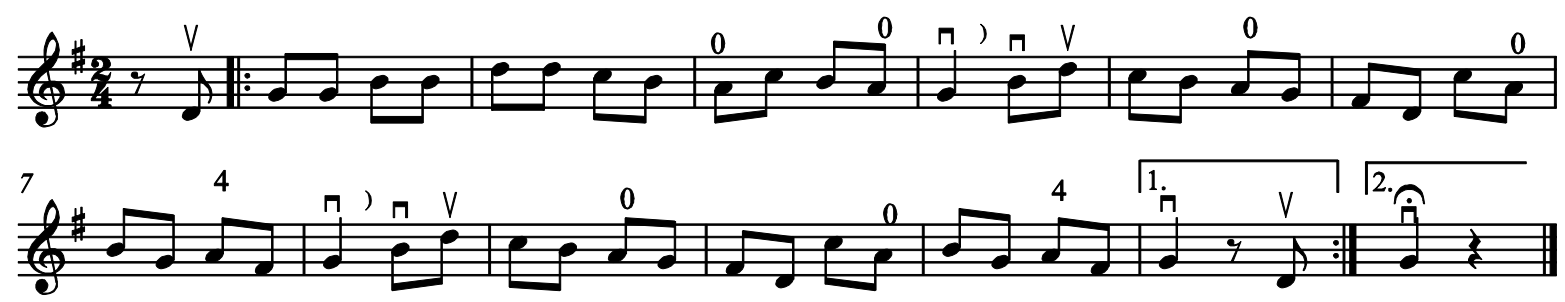

O exercício 131 apresenta a canção folclórica original Vamos maninha. O uso do quarto dedo na corda ré no início do exercício é acrescido da dificuldade da síncopa com duas arcadas para cima.

O segundo dedo na corda lá se apresenta como dó\# separado do primeiro dedo no compasso 3, e como dó natural com sinal de bequadro, próximo do primeiro dedo nos compassos 5 e 9. Além disso o segundo dedo na corda ré sempre se apresenta como fá\# de acordo com a armadura de clave.

\section{Vamos maninha - melodia original}

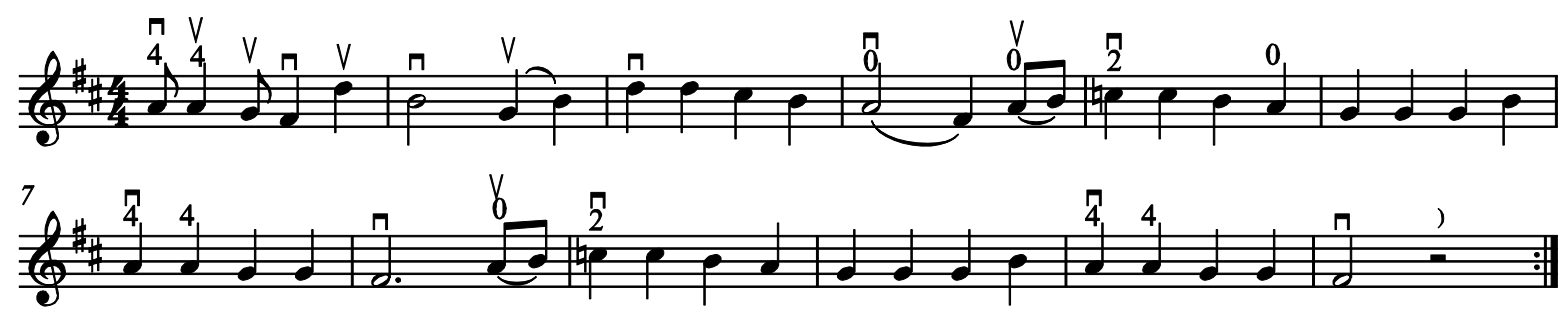

O exercício 132 apresenta a canção folclórica original Caranguejo, com uso do quarto dedo na corda lá, e segundo dedo próximo do primeiro nas cordas mi e lá. Ressaltamos o uso dos dedos presos na corda nos compassos 5, 7, 13, 14 e 15.

\section{Caranguejo - melodia original}

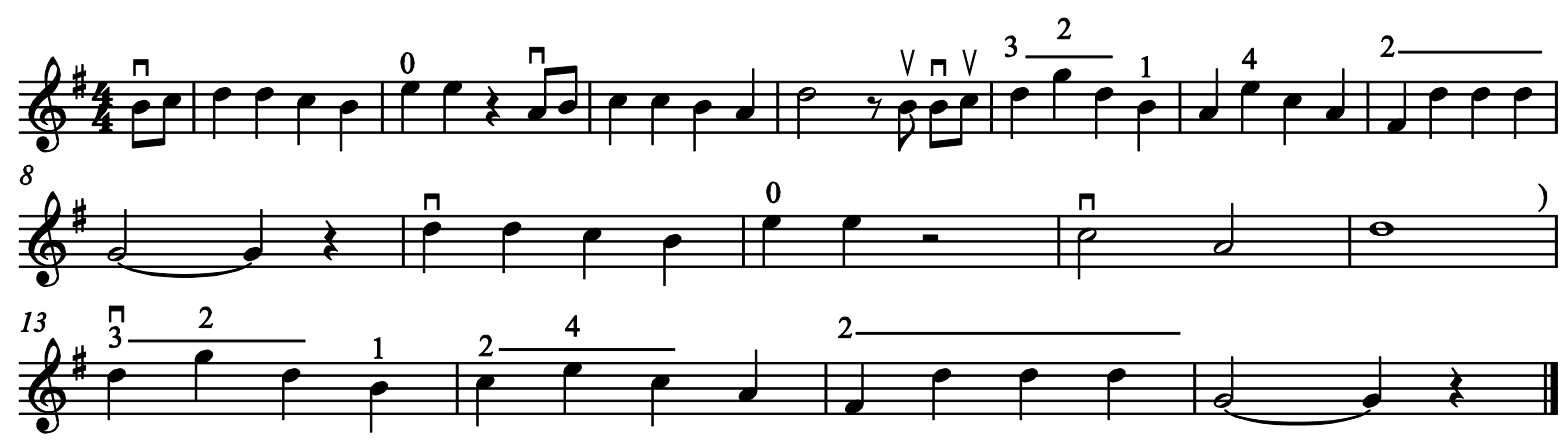


195

O exercício 133 apresenta a canção folclórica original Fui no Itororó. A primeira repetição deste exercício é da capo, ou desde o início do exercício. O arco requer maior atenção do aluno nos compassos 4, 8, 9, 17, 21 e 23, pois deve ser tocado com duas arcadas para baixo, sem retomada de arco desde o início do talão.

133. Fui no Itororó- melodia original
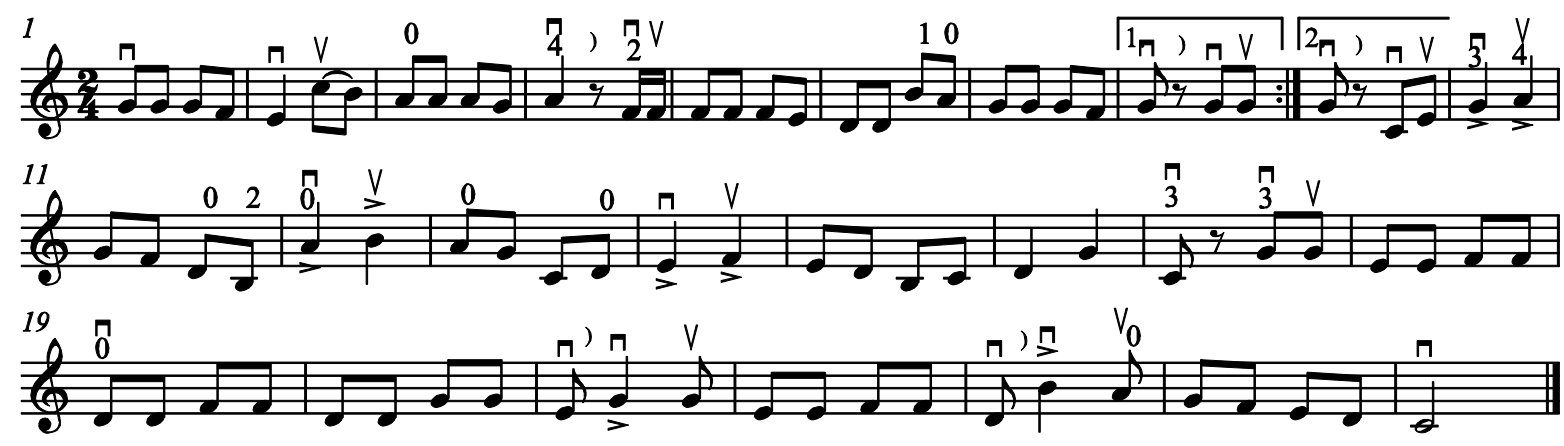

O exercício 134 apresenta a canção folclórica original Os escravos de Job. Neste exercício, embora a tonalidade seja de sol maior, no compasso 3 o fá está com o sinal de bequadro, resultando na nota fá natural.

134. Os escravos de Job - melodia original
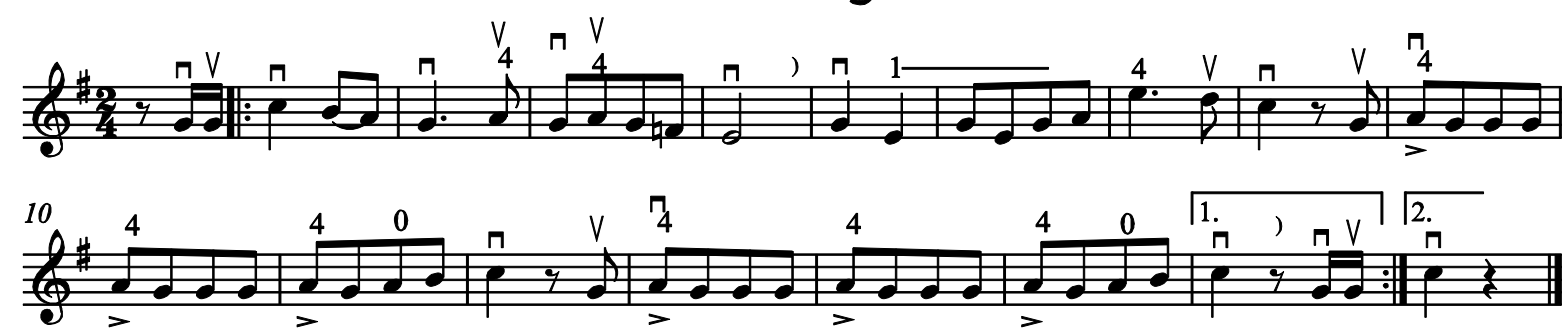

O exercício 135 apresenta a canção folclórica original Os pombinhos. No compasso 8 ocorre duas arcadas para cima, com economia de movimento, sem retomada de arco desde a ponta.

135. Os pombinhos - melodia original
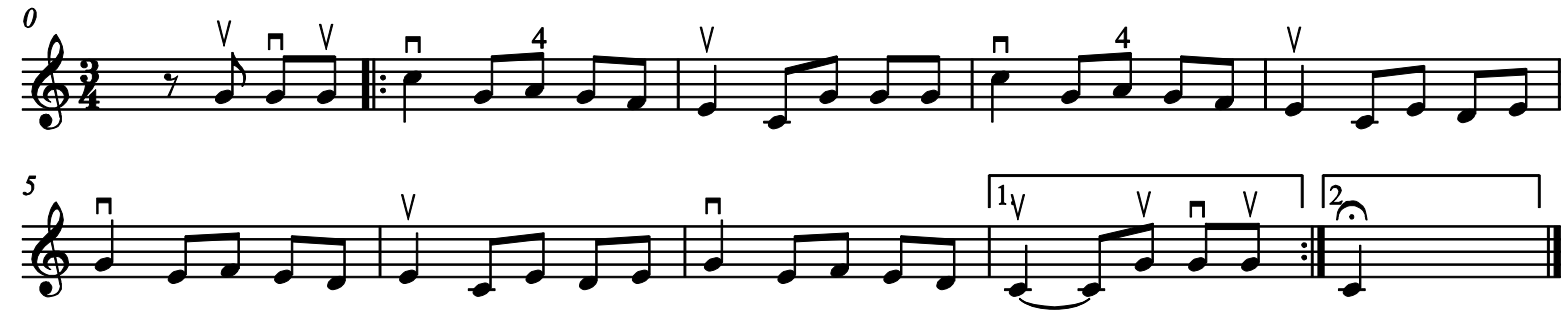
O exercício 136 apresenta a canção folclórica original Margarida. No compasso 4 ocorre duas arcadas para cima, com economia de movimento, sem retomada de arco desde a ponta.

\section{Margarida- melodia original}

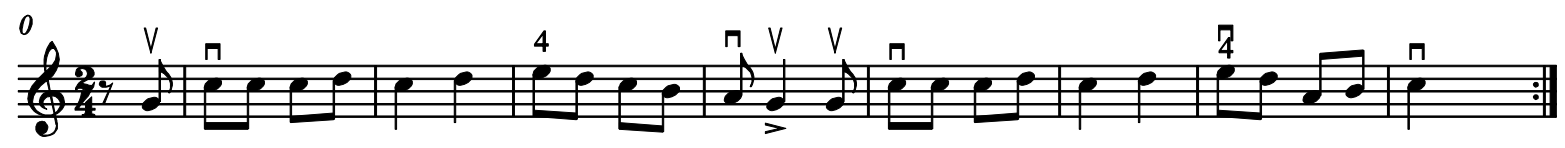

O exercício 137 apresenta a canção folclórica original Sapo cururu. O aluno deve considerar com atenção as diferentes colocações do segundo dedo, que está separado do primeiro dedo nas cordas ré e lá, e próximo do primeiro dedo, na corda mi.

\section{Sapo Cururu - melodia original}

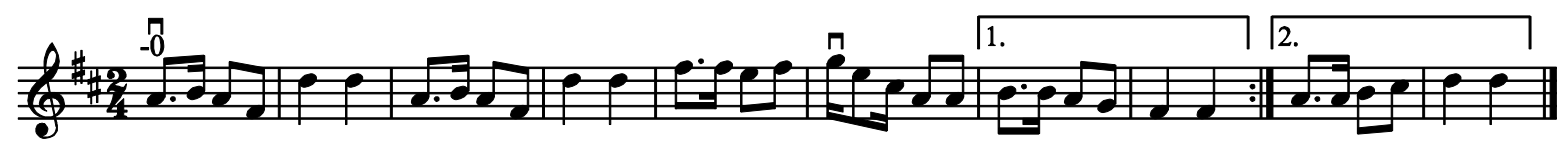

O exercício 138 apresenta a canção folclórica original Entrei na roda. O compasso 8 requer duas arcadas para cima com economia de movimentos, sem retomar desde o talão. No último compasso a última nota tem staccato e deve ser executada com apoio do arco na corda de modo que o movimento seja curto para a nota soar seca, sem reverberação.

\section{Entrei na roda - melodia original}

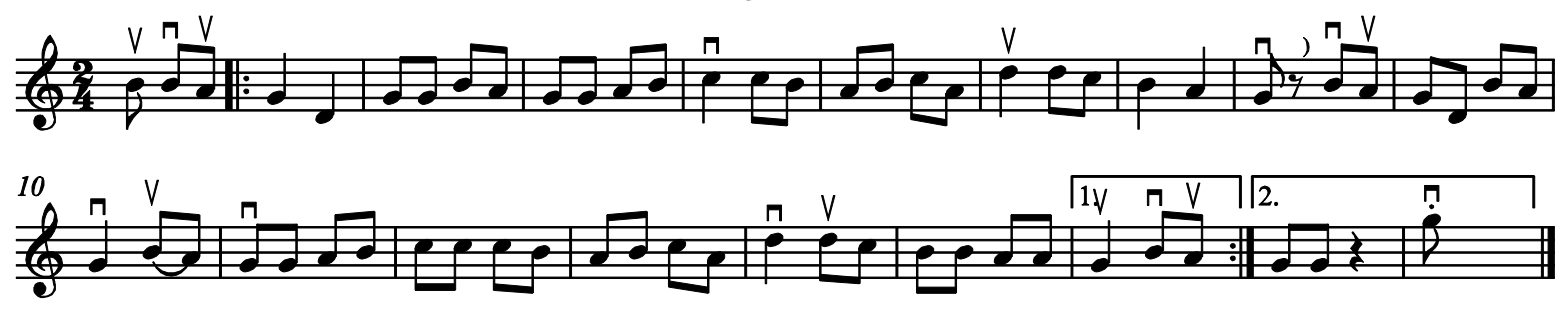

O exercício 139 apresenta a canção folclórica original Quando eu era pequenino. A dificuldade técnica apresentada neste exercício é a permanência dos 
dedos, simbolizada pelo traço longo junto ao dedilhado. Destacamos as quintas dedilhadas do compasso 15 , que devem ser executadas sem retirar o terceiro dedo da corda. O aluno deve empurrar o terceiro dedo desde a corda sol até a corda ré.

\section{Quando eu era pequenino - melodia original}
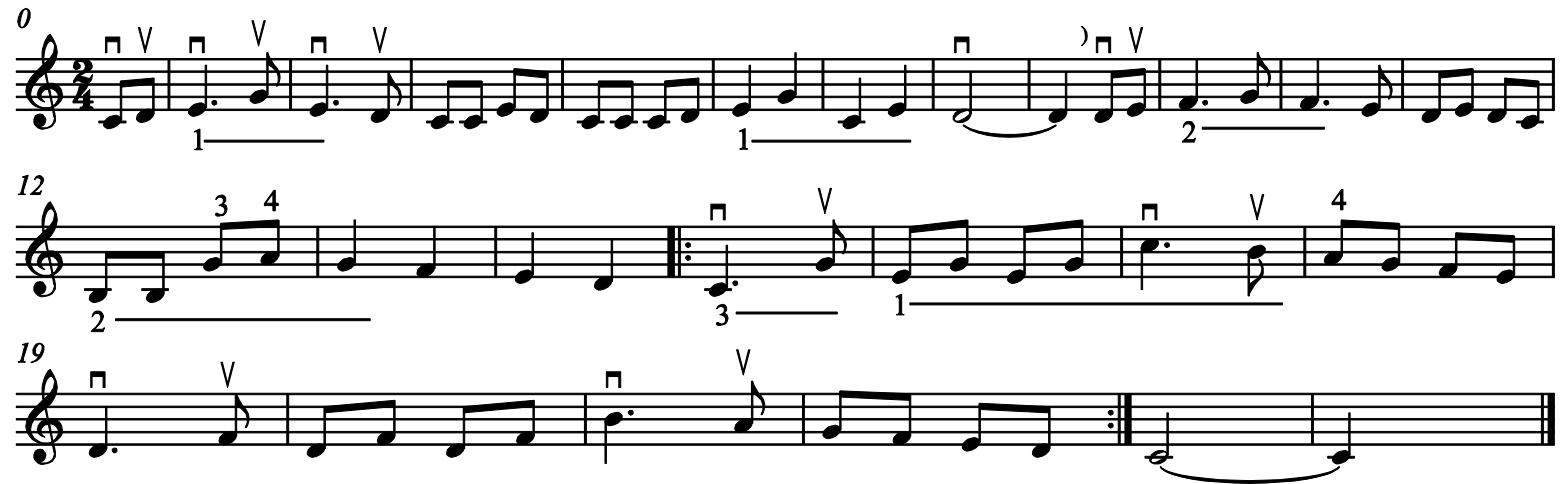

\section{Lição 14}

A lição 14 é composta por 10 exercícios, do número 140 ao 150. O conteúdo técnico desenvolvido nesta lição segue abaixo:

- Colocação do segundo dedo em diversas posições nas diferentes cordas durante um mesmo exercício;

- Arcadas múltiplas, com duas arcadas no mesmo sentido;

- Ritmos sincopados variados;

- Uso de todos os elementos apresentados nas lições anteriores.

O exercício 140 apresenta a canção folclórica original Que lindos olhos.

\section{Que lindos olhos - melodia original}

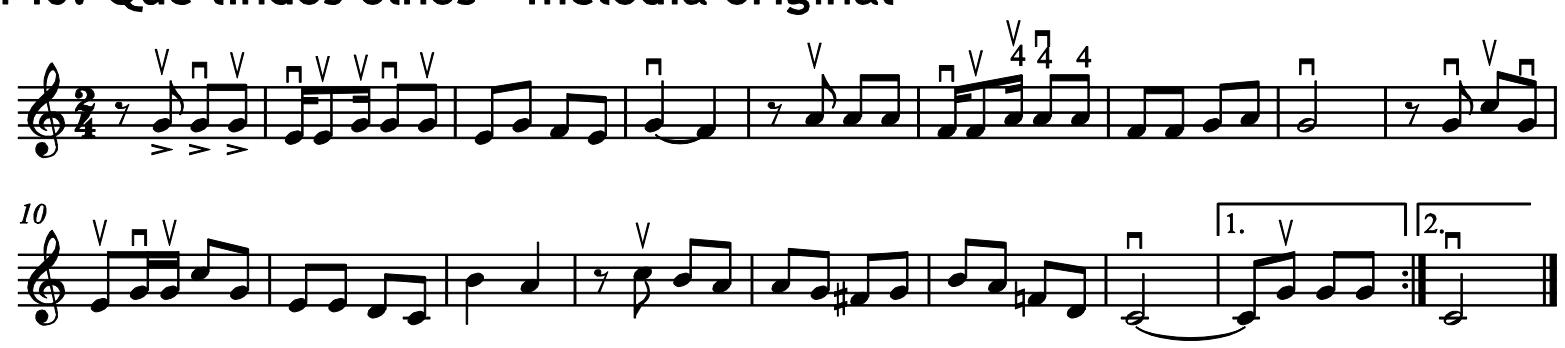


O exercício 141 apresenta primeira linha melódica coadjuvante para a canção folclórica Que lindos olhos.

\section{Que lindos olhos 1}

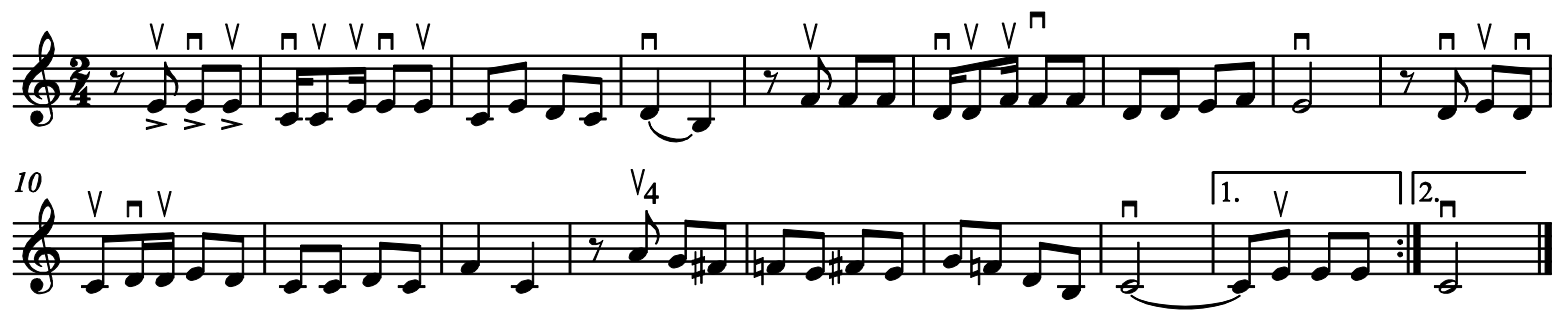

O exercício seguinte é o mesmo que o anterior, acrescido da linha do professor. A tonalidade apresentada é de dó maior.

\section{1a. Que lindos olhos 1a}
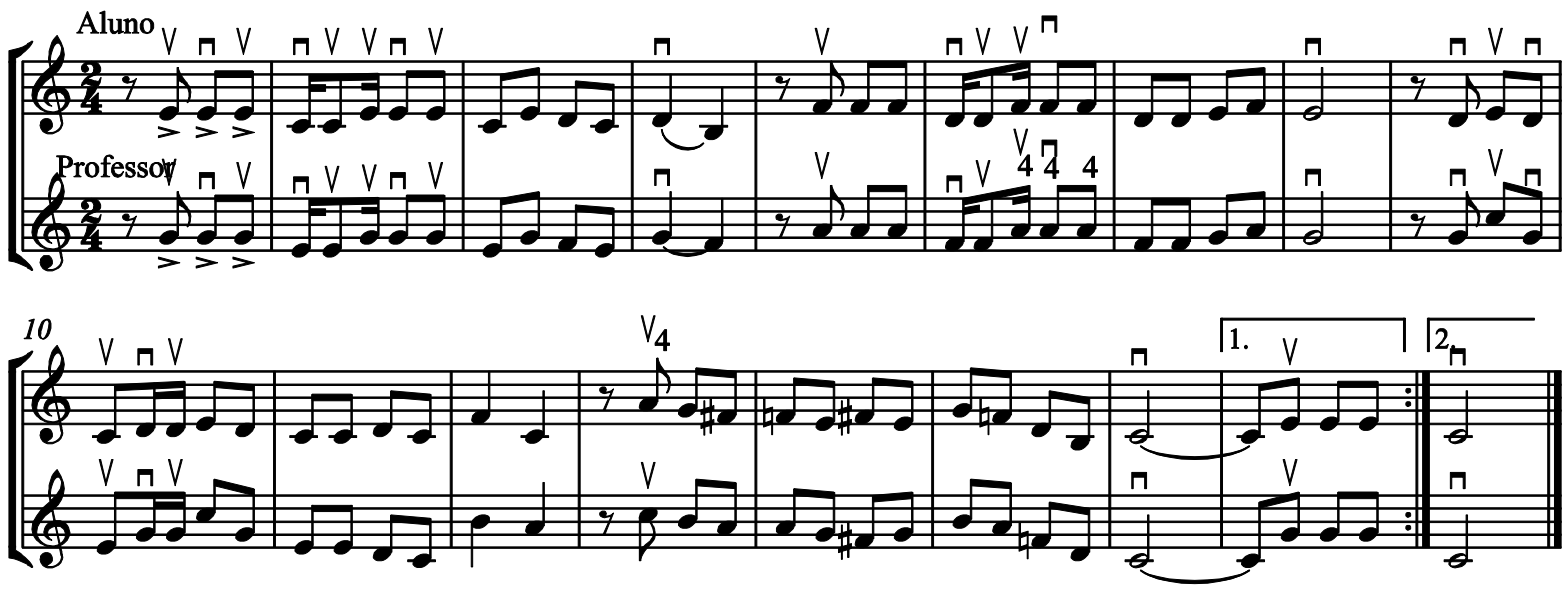

O exercício 142 apresenta a canção folclórica original Pai Francisco. O aluno deve considerar com atenção a mudança do segundo dedo no compasso 15, ao tocar dó natural com o segundo dedo próximo do primeiro e logo em seguida tocar fá\#, afastando o segundo dedo do primeiro.

\section{Pai Francisco - original}
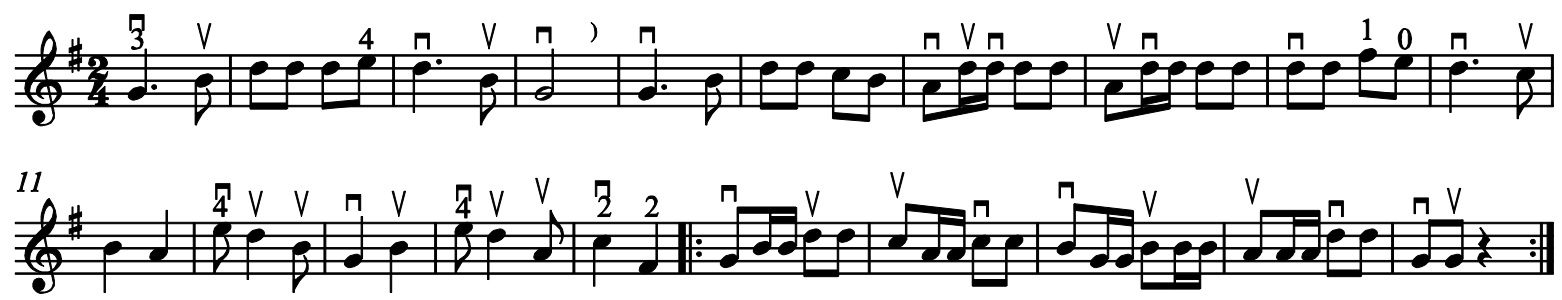
O exercício 143 apresenta a canção folclórica original Passe, passe gavião. $\mathrm{O}$ segundo dedo deve ser próximo do primeiro dedo na corda lá, resultando na nota dó natural. A divisão do arco deve ser estudada com atenção, por conta das retomadas rápidas do arco nos compassos 4, 5 e 6, e dos acentos musicais a partir do compasso 6.

\section{Passe, passe gavião - melodia original}
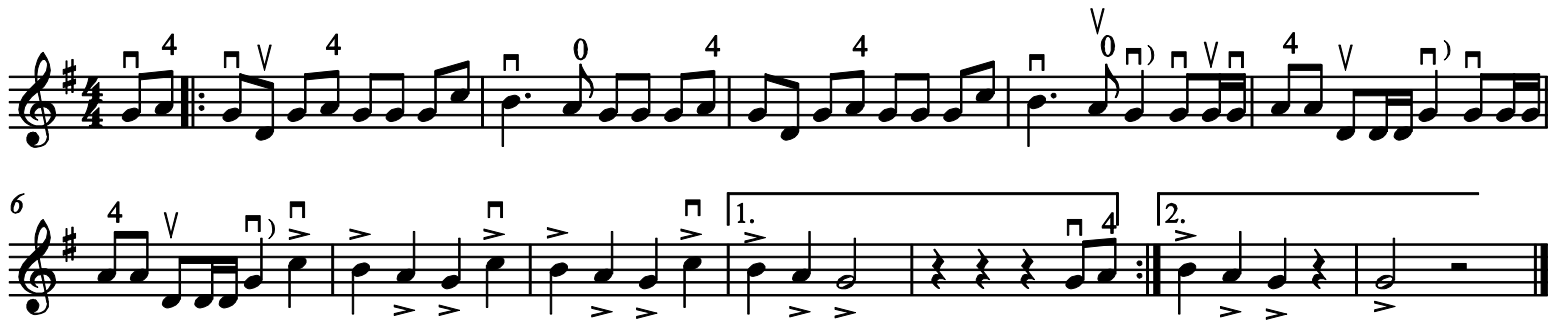

O exercício 144 apresenta a canção folclórica original Meninas, ó meninas.

144. Meninas, ó meninas - melodia original

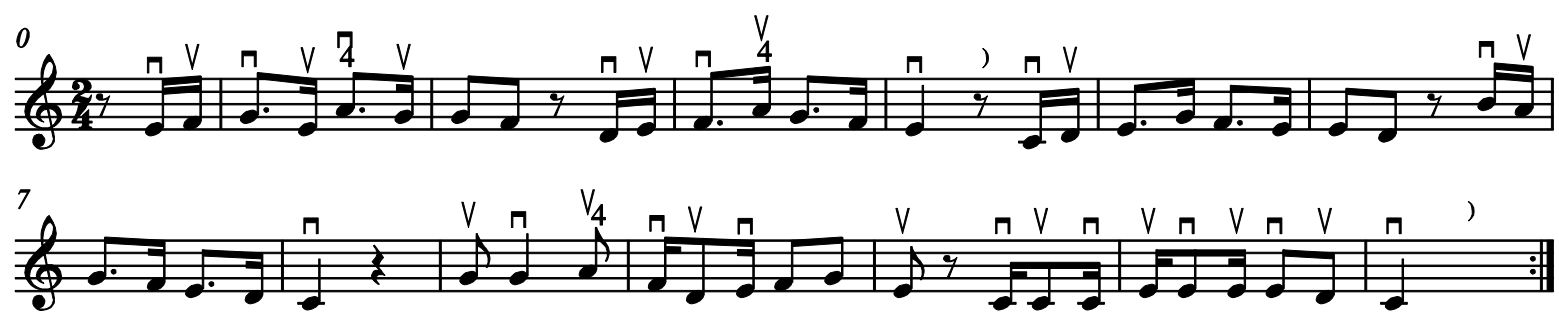

O exercício 145 apresenta a canção folclórica original Ó limão.

\section{5. Ó limão - melodia original}

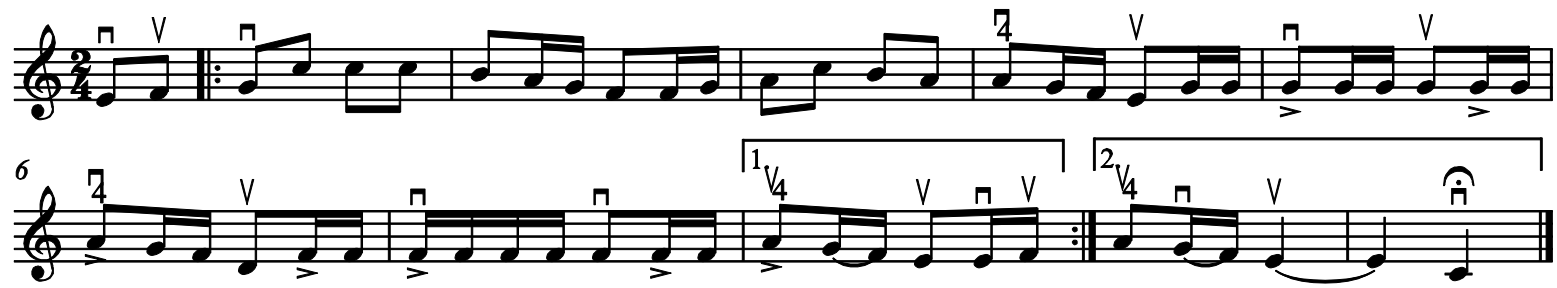

O exercício 146 apresenta a canção folclórica original Lindas laranjas. 
146. Lindas Laranjas- melodia original

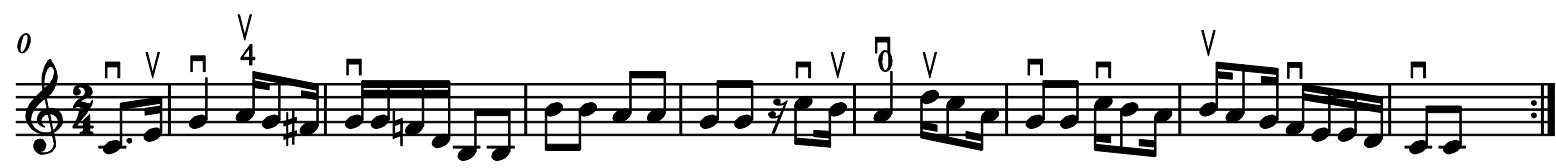

O exercício 147 apresenta a canção folclórica original As conchinhas. O aluno deve considerar com atenção com uso de quarto dedo na corda ré, resultando na nota lá dedilhada, assim como o uso da corda lá solta. O emprego do arco tocando duas notas separadas na mesma direção deve ser estudado fazendo um reforço na articulação em cada nota, calculando bem a divisão do arco.

\section{As conchinhas - melodia original}

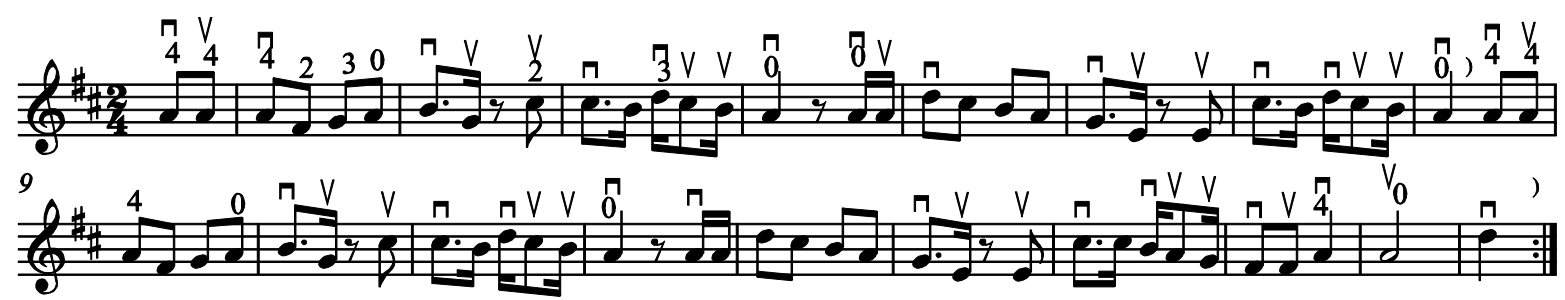

O exercício 148 apresenta a canção folclórica original Na corda da viola. O traço abaixo das semicolcheias do primeiro compasso e semelhantes ressalta o caráter de reforço da articulação.

\section{Na corda da viola - original}
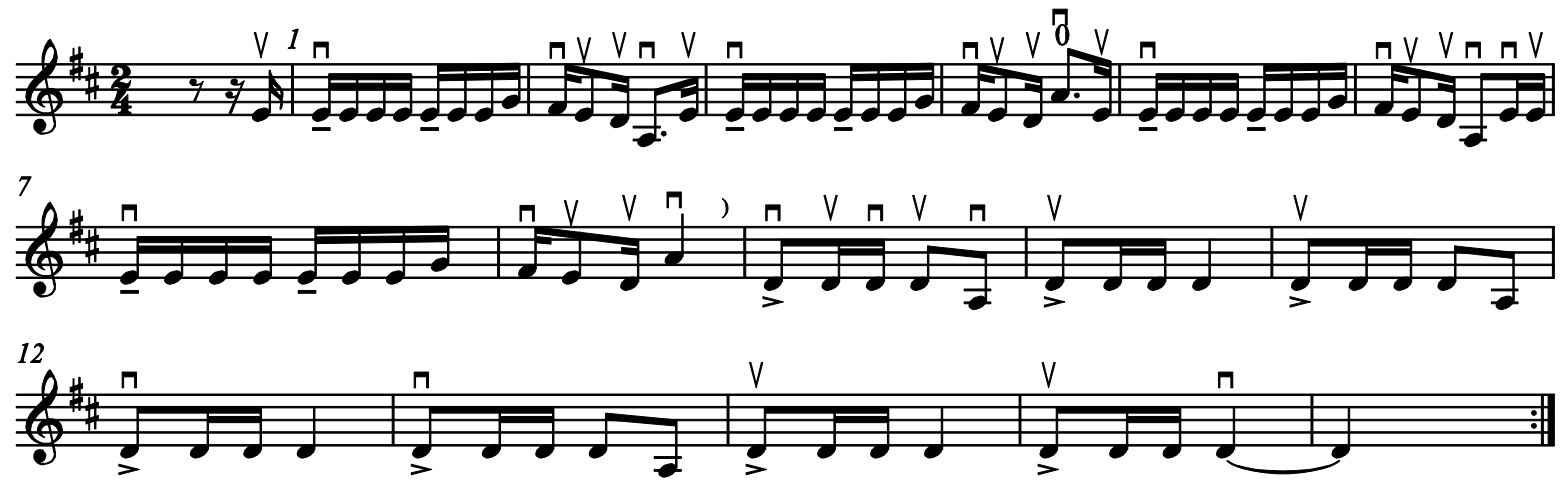

O exercício 149 apresenta a canção folclórica original Carneirinho, carneirão.

149. Carneirinho, carneirão - melodia original

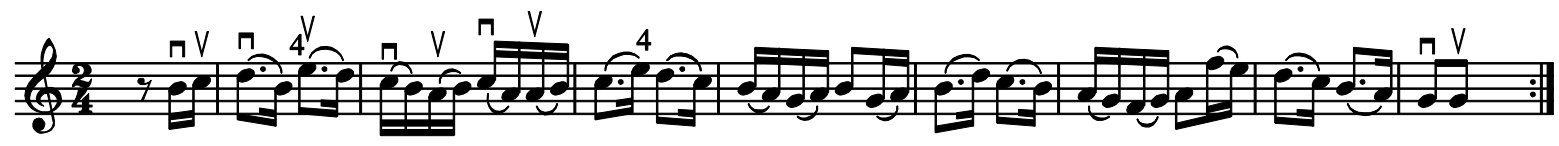


O exercício 150 apresenta a canção folclórica original Xô! Passarinho.

\section{Xô! Passarinho - melodia original}

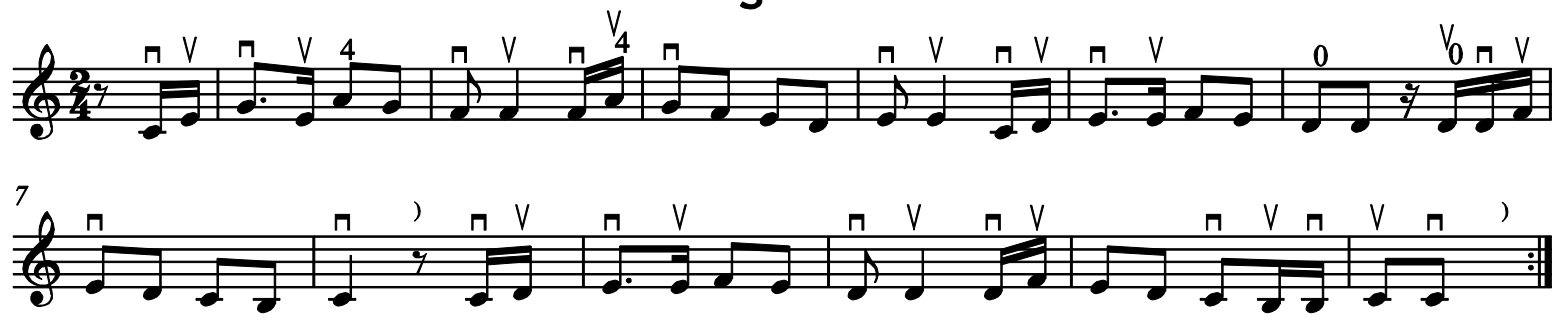




\section{CONSIDERAÇÕES FINAIS}

Este trabalho foi desenvolvido tendo como meta demonstrar a importância da aplicação de fundamentos da psicomotricidade ao ensino coletivo de violino. Para tanto, arrolamos um elenco relevante de informações técnicas relacionando-o com a atividade da performance musical propriamente dita.

Discutimos aqui os diversos aspectos do ensino coletivo, desde sua organização e estrutura até questões metodológicas determinantes para o sucesso de nossa proposta. Para dar concretude à hipótese geradora desse trabalho, elaboramos um método para alunos iniciantes, considerando princípios da psicomotricidade e do desenvolvimento motor.

O uso dos exercícios preparatórios é de extrema importância no contexto da nossa metodologia, uma vez que ensina o corpo a se ajustar para a nova atividade, formando novos circuitos neuronais, programando os comandos cerebrais, preparando a musculatura da criança e desenvolvendo os movimentos requeridos no violino. Tudo isso feito sem o uso efetivo do instrumento, favorecendo o aprendizado dos movimentos e evitando o acúmulo de tensão muscular.

Nossa experiência pessoal tem demonstrado que turmas de ensino coletivo que tiveram a oportunidade de desenvolver os exercícios preparatórios durante 16 aulas quando passaram a tocar efetivamente com o arco no violino -, progrediram muito mais do que as turmas que não o fizeram. Os resultados apresentados pelas turmas que fizeram os exercícios preparatórios foram melhores e permanentes, como a correta postura do instrumento mais firme e a musculatura mais relaxada, o que nos encoraja a recomendar firmemente o seu uso.

Chegando ao final dessa longa jornada de trabalho, envolvendo muita pesquisa, cursos específicos e extra curriculares, discussão e elaboração de conceitos, gestação dos exercícios preparatórios, concepção metodológica para a criação de cada um dos exercícios progressivos de violino, acredito que tenhamos dado consistência à proposta que lançamos.

Esperamos que esta pesquisa venha a contribuir para 0 crescimento e 0 desenvolvimento do ensino musical em nosso país. 


\section{REFERÊNCIAS}

ANDERSON, G.E.; FROST, R.S. All for Strings: Comprehensive String Method. San Diego: Kjós Neil A. Kjós Music Company, 1986.

APPLEBAUM, Samuel. String Builder: a String Class Method for Class or Individual Study. New York: Belwin Mills, 1960.

ASSAIANTE, Christine; AMBLARD, Bernard. An ontogenetic model for the sensorimotor organization of balance control in humans. Human Movement Science, v. 14, Elsevier, 1995.

AUER, Leopold. Violin playing. As I teach it. New York, Dover Publications, 1980.

BACHMANN, Alberto Abraham. An encyclopedia of the violin. New York: Da Capo Press, 1966.

BARRETO, Ceição de Barros. Organização e técnica de coro; canto coral. Petrópolis: Vozes, 1973.

BENHAM, Stephen J.; WAGNER, Mary L.; ATEN, Jane Linn; EVANS, Judith P.; ODEGAARD, Denese; LIEBERMAN, Julie Lyonn. ASTA Curriculum, Standards, Goals and Learning Sequences for Essential Skills and Knowledge in K-12 String Programs. Fairfax, VA, USA: American String Teachers Association, 2011.

BERNSTEIN, N. A. The Coordination and Regulation of Movements. Oxford:

Pergamon Press, 1967.

BISQUOLO, Paulo Augusto. As leis de Newton. Disponível em:

<<http://educacao.uol.com.br/fisica/dinamica-as-leis-de-newton.jhtm/〉>. Acesso em: 05 jul. 2012.

BOSíSıO, Paulo. Paulina D’Ambrósio e a modernidade violinística no Brasil. Dissertação de Mestrado. Rio de Janeiro, UNI-RIO, 1996.

BRASIL, Secretaria de Educação Fundamental. Parâmetros curriculares nacionais: Introdução aos Parâmetros Curriculares Nacionais - vol. 1. Brasília: MEC, 1997.

BRASIL, Secretaria de Educação Fundamental. Parâmetros curriculares nacionais: arte - Ensino de quinta a oitava séries. Brasília: MEC, 1998.

CANDÉ, Roland de. História Universal da Música (3 vol.) São Paulo: Martins Fontes, 1994.

Charles SOLLINGER, The music man and the professors: a history of string class methods in USA, 1811-1911. Doctor of Education. Ann Arbor, MI, The University of Michigan, 1970. Tese não publicada.

CONTIER, Arnaldo D. Passarinhada do Brasil: conto orfeônico, educação e getulismo. Bauru: EDUSC, 1998. 
COSTALLAT, Dalila M. de. La Entidad Psicomotriz. Buenos Aires: Editorial Losada S. A., 1984.

CRUVINEL, Flavia Maria. Educação Musical e Transformação Social - uma experiência com ensino coletivo de cordas. Goiânia: Instituto Centro-Brasileiro de Cultura, 2005.

De MEUR, A. e STAES, L. Psychomotricité Éducation et Reéducation. Trad. Ana Maria I. Galuban; Setsuko Ono. São Paulo: Manole, 1991.

DIAS, José Leonel G. Iniciação e prática de instrumentos de corda através do ensino coletivo. Dissertação de Mestrado. São Paulo, ECA-USP, 1993.

DOURADO, Henrique Autran. O Arco dos Instrumentos de Cordas, Compêndio Teórico e Técnico. Tese de Doutorado. São Paulo, ECA-USP, 1998.

DUKE, Robert A. Intelligent Music Teaching, essays on the core principles of effective instruction. Texas: Learning and Behavior Resources, 2005.

FITTS, P. M.; POSNER, M. I. Human Performance. Belmont: Brooks Cole, 1967.

FLESCH, Carl. The art of violin playing - Book one: "Technique in General, Applied Technique". Trad. Frederick H. Martens. New York: Carl Fischer, 1939. Book two: "Artistic Realization and Instruction". Trad. Frederick H. Martens. New York: Carl Fischer, 1930.

FONSECA, Marcos; LOMBARDI, Adélia. Projeto Guri 1995-2002. São Paulo: Secretaria de Cultura do Governo de São Paulo, 2002.

FONSECA, Vítor da. Manual de observação psicomotora: significação psiconeurológica dos fatores psicomotores. Porto Alegre: Artes Médicas, 1995.

FONTERRADA, Marisa Trench de Oliveira. De tramas e fios - Um ensaio sobre música e educação. São Paulo: Editora UNESP, 2005.

FRANÇA, Maria Ignez T (Trad. e Ed.). Resumão: Anatomia de Superfície.

Consultoria: Dr. Orlando José Barone e Dra. Leda Calvo Barone. Coleção Medicina no. 18. São Paulo: Barros, Fischer e Associados, 2004.

Resumão: Esqueleto. Consultoria: Dra. Egle Costa Oppi. Coleção Medicina no. 8. São Paulo: Barros, Fischer e Associados, 2006.

Resumão: Sistema Muscular. Consultoria: Dra. Egle Costa Oppi. Coleção Medicina no 7. São Paulo: Barros, Fischer e Associados, 2005.

FURTH, Hans G. Piaget na sala de aula. Rio de Janeiro: Forense Universitária, 1997.

GAINZA, Violeta H. de. Estudos de Psicopedagogia Musical. Trad. Beatriz A. Cannabrava. São Paulo: Summus, 1998.

GALAMIAN, Ivan. Principles of violin playing and teaching. 3. ed., Shar Products Co., 1999. 
GALINDO, João M. Instrumentos de arco e ensino coletivo: A construção de um método. Dissertação de Mestrado. São Paulo, ECA-USP, 2000.

GARCIA, José Roberto. Apostila de Dinâmica 1. São Paulo, 2001. Disponível em: <<http://www.mackenzie.br/fileadmin/Graduacao/EE/Arquivos/dinamica.pdf>>. Acesso em: 05 julho 2012.

GODFREY, B.B e KEPHART, N.C. Movement Patterns and Motor Education. New York: Appleton Century Crofts, 1969.

GORDON, Edwin E. Teoria de aprendizagem Musical para Recém-Nascidos e Crianças em Idade Pré-Escolar. Revisão Helena Rodrigues. 3ª̣ed., Lisboa: Fundação Calouste Gulbenkian, 2008.

. Essential Preparation for Beginning Instrumental Music Instruction. Chicago: GIA Publications, 2010.

GROUT, Donald J.; PALISCA Claude V. História da Música Ocidental. Lisboa: Gradiva, 2005.

HAYWOOD, Kathleen M.; GETCHELL, Nancy. Desenvolvimento Motor ao Longo da Vida. Trad. Ricardo D.S. Petersen; Fernando de Siqueira Rodrigues. University of Missouri, St Louis. Porto Alegre: Artmed, 2004.

HENRI WALLON. Disponível em:

<<http://educarparacrescer.abril.com.br/aprendizagem/henri-wallon-307886.shtm>>. Acesso em: 06 jun. 2011.

HIJIKI, Rose Satiko G. A música e o risco: etnografia da performance de crianças e jovens. São Paulo: Edusp, 2006.

HORTA, Luís Paulo. Heitor Villa-Lobos. Rio de Janeiro: Alumbramento/Livroarte, 1986.

INSTABILIDADE VERTEBRAL. Disponível em:

$<<w w w$.itcvertebral.com.br/instabilidade-vertebral/instabilidade-vertebral >>. Acesso em: 07 jul. 2012.

JARDIM, Gil. O estilo antropofágico de Heitor Villa-Lobos. São Paulo: Philarmonia Brasileira, 2005.

JORDÃO, Gisele; ALLUCCI, Renata R; MOLINA, Sérgio; TERAHATA, Adriana M. (coord.). São Paulo: Allucci \& Associados Comunicações, 2012.

KAGAN, A; SALING, M.M. Uma introdução a afasiologia de Luria: teoria e aplicação. São Paulo: Artes Médicas, 1997. Disponível em:

s<http://cursoaprendizagem.blogspot.com/2009/05/imagens-de-apoio.html\#uds-sear ch-results >>. Acesso em: 17 mai. 2011.

KAPIT, W. e ELSON, Lawrence M. The Anatomy Coloring Book. Trad. Walter Biazotto. São Paulo:Roca, 1987. 
KIEFER, Bruno. História da música brasileira, dos primórdios ao início do séc. $X X$. Porto Alegre: Movimento, 1976.

KOVÁCS, Géza e PÁSZTOR, Zsuzsa. Ejercicios preparatorios para instrumentistas método Kovács. Trad. Eva Reyes de Uña. Barcelona: Editorial Graó, 2010.

LE BOULCH, J. A Educação pelo Movimento: a Psicocinética na Idade Escolar. Porto Alegre: Artes Médicas, 1983.

LOUREIRO, B. Apostila do curso Psicomotricidade na Escola. São Paulo, ISPE-GAE, 2010.

LOZANO, Fabiano. Sugestões para o ensino da música. São Paulo, Diretoria Geral do Ensino do Estado de São Paulo, 1931.

MAGILL, Richard A. Aprendizagem Motora: Conceitos e Aplicações. Trad. Erik Gerhard Hanitzsch. Louisiana: Edgard Blücher, 1984.

MARCONDES, Marco Antônio (org.). Enciclopédia da Música Brasileira: popular, erudita e folclórica. 3ª ed., São Paulo: Publifolha, 2000.

MARIZ, Vasco. Dicionário Biográfico Musical: compositores, intérpretes e musicólogos. Rio de Janeiro: Philobiblion, 1985.

Ed. UERJ, 1997. (org). Francisco Mignone - o homem e a obra. Rio de Janeiro: Funarte/ . História da música no Brasil. 5e ed., São Paulo: Nova Fronteira, 2000.

MÁRSICO, Leda Osório. A criança e a música. Porto Alegre-Rio de Janeiro: Globo, 1982.

MARTINS, Raimundo. Educação Musical: Conceitos e Preconceitos. Rio de Janeiro: FUNARTE, 1985.

MASSIN, Jean; MASSIN, Brigitte. História da música ocidental. Rio de Janeiro: Nova Fronteira, 1997.

MATEIRO, Tereza; ILARI, Beatriz. Pedagogias em Educação Musical. Curitiba: IBPEX, 2011.

MELLO, Alexandre Moraes de. Psicomotricidade, Educação Física e Jogos Infantis. São Paulo: IBRASA, 1989.

MUÑOZ MUÑOZ, Luiz Armando. Desenvolvimento Motor e suas implicações na Educação Física Infantil. Dissertação de Mestrado. São Paulo, EEFE-USP, 1985.

MUSSEN, Paul Henry; CONGER, John Janeway e KAGAN, Jerome. Desenvolvimento e Personalidade da Criança. Trad. Maria Silvia Mourão Netto. São Paulo: Harper \& Row, 1977. 
OLIVEIRA, Enaldo A. J. O ensino coletivo dos instrumentos de corda - reflexão e prática. Dissertação de Mestrado. São Paulo, ECA-USP, 1998.

PIAGET, J. La Naissance de l'Intelligence chez l'Enfant, Delachaux et Niestlé, Paris, 1965.

ROLLAND, Paul; MUTSCHLER, M. The Teaching of Action in String Playing. Chicago: Illinois University Press, 1974.

ROMERO, Sílvio. Folclore brasileiro: cantos populares do Brasil. Belo Horizonte: Itatiaia, 1985.

SÁ, Maria Teresa Marques de. Física $12^{\circ}$ ano. Unidade 1, "Força e Movimento". Universidade de Aveiro, Lisboa: Texto Editora, 1aㅡ edição, 2001.

SADIE, Stanley (org). Dicionário Grove de Música (edição concisa). São Paulo: Jorge Zahar, 1994.

SÁNCHEZ, Pilar Arnaiz; MARTÍNEZ, Marta Rabadán; PEÑALVER Iolanda Vives. A Psicomotricidade na Educação Infantil, uma prática preventiva e educativa. Trad. Inajara Haubert Rodrigues. Porto Alegre: Ed. Artmed, 2003.

SANTIAGO, Diana; BROOCK, Angelita M. V; CARVALHO, Tiago (orgs.). Educação Musical Infantil. Salvador: PPGMUS UFBA, 2011.

SARKIS, N. A., PIRES, M.F. e GUADALUPE, A. O. Física. V. 2. São José dos Campos: Ed. Poliedro, 2011.

SIMPSON, Elisabeth J. The classification of educational objectives: The psychomotor domain. Versão resumida republicada por SINGER, R.N.; DICK, W. em Teaching physical education: A systems approach. Boston: Houghton-Mifflin, 1974.

SQUEFF, Enio; WISNIK, José Miguel. Música - o nacional e o popular na cultura brasileira. São Paulo: Melhoramentos, 1982.

STOWELL, Robin. Violin technique and performance practice in the late eighteenth and early nineteenth centuries - Cambridge musical texts and monographs. Cambridge: Cambridge University Press, 1985.

SUETHOLZ, Robert John. A História do Violoncelo - parte I. Pesquisa realizada para ingresso pelo RTC como professor de violoncelo do Departamento de Música da ECA-USP. São Paulo, 1991.

SUZUKI, Shinichi et al. The Suzuki Concept: An Introduction to a successful Method for Early Music Education. Ed. Elisabeth Mills Therese C. Murphy. Berkeley, Califórnia: Diablo Press, 1973.

SUZUKI, Shinichi. Educação é Amor - um novo método de educação. Santa Maria: Imprensa Universitária, 1983. 
TEORIA DE VIGOTSKY. Disponível em: <<http://www.dfi.ccet.ufms.br/prrosa/Pedagogia/Capitulo_5.pdf $>>$. Acesso em: 10 abr. 2012.

TURNER, Barrie Carson. O mundo do violino - um livro ilustrado para conhecer a arte, a história e a técnica do instrumento. São Paulo: Melhoramentos, 1997.

VILLA-LOBOS, Heitor. Educação Musical. Presença de Villa-Lobos. Rio de Janeiro: Museu Villa-Lobos, Instituto Brasileiro do Patrimônio Cultural, 1991, Vol.13. Vitale, 1932.

Guia Prático - Estudo Folclórico Musical. 1ํvolume. Rio de Janeiro:

WALLON, H. Do Acto ao Pensamento. Lisboa: Portugália, 1969. 